UNIVERSIDADE DE SÃO PAULO

ESCOLA DE COMUNICAÇÕES E ARTES

STEFANIE CARLAN DA SILVEIRA

Conteúdo jornalístico para smartphones: o formato da narrativa sistêmica no jornalismo ubíquo

São Paulo 
STEFANIE CARLAN DA SILVEIRA

Conteúdo jornalístico para smartphones: o formato da narrativa sistêmica no jornalismo ubíquo

Tese doutoral apresentada à Escola de Comunicações e Artes da Universidade de São Paulo (ECA/USP) para obtenção do título de Doutora em Ciências da Comunicação. Área de Concentração: Teoria e Pesquisa em Comunicação. Linha de Pesquisa: Comunicação e Ambiências em Redes Digitais.

Orientadora: Profa. Dra. Elizabeth Nicolau Saad Corrêa.

São Paulo 
Autorizo a reprodução e divulgação total ou parcial deste trabalho, por qualquer meio convencional ou eletrônico, para fins de estudo e pesquisa, desde que citada a fonte.

Catalogação na Publicação

Serviço de Biblioteca e Documentação

Escola de Comunicações e Artes da Universidade de São Paulo

Dados fornecidos pelo(a) autor(a)

Silveira, Stefanie Carlan da

Conteúdo jornalístico para smartphones: o formato da

narrativa sistêmica no jornalismo ubíquo / Stefanie Carlan

da Silveira. -- São Paulo: S. C. Silveira, 2017.

224 p.: il.

Tese (Doutorado) - Programa de Pós-Graduação em Ciências

da Comunicação - Escola de Comunicações e Artes /

Universidade de São Paulo.

Orientadora: Elizabeth Nicolau Saad Corrêa

Bibliografia

1. Jornalismo 2. Smartphones 3. Dispositivos móveis 4. Jornalismo ubíquo 5. Ubiquidade I. Nicolau Saad Corrêa, Elizabeth II. Título.

CDD 21.ed. - 070 
SILVEIRA, S. C. Conteúdo jornalístico para smartphones: o formato da narrativa sistêmica no jornalismo ubíquo. 2017. 223f. Tese (Doutorado em Ciências da Comunicação) - Escola de Comunicações e Artes, Universidade de São Paulo (ECA/USP), São Paulo, 2017.

Aprovado em:

-_-_-_-_ I - -

Banca Examinadora

Prof. Dr.

Instituição:

Julgamento:

Prof. Dr.

Instituição:

Julgamento:

Prof. Dr.

Instituição:

Julgamento:

Prof. Dr.

Instituição:

Julgamento:

Prof. Dr.

Instituição:

Julgamento:

Prof. Dr.

Instituição:

Julgamento: 


\section{AGRADECIMENTOS}

A Deus, porque sempre caminho por fé, não por aquilo que me é possível ver.

Aos meus pais por serem a base fundamental de mim e a rocha na qual construí minha morada.

Ao João, por tornar o amor real, por decidir caminhar ao meu lado e trazer mais sentido a esta jornada.

A Lucy, por não sair de baixo da minha cadeira desde os tempos da dissertação.

À minha orientadora Elizabeth Saad por toda condução deste trabalho e da minha trajetória no doutorado da melhor forma possível, sempre generosa, compreensiva e presente.

Ao professor Ramón Salaverría que me abriu as portas da Universidade de Navarra tão generosamente, contribuindo de forma fundamental para a realização deste trabalho.

À Universidade de São Paulo, à Escola de Comunicações e Artes e ao Programa de Pós-Graduação em Ciências da Comunicação pela oportunidade de realizar esta pesquisa.

A CAPES (Coordenação de Aperfeiçoamento de Pessoal de Nível Superior) por financiar este trabalho e, apesar de todas as intempéries governamentais, ainda permitir a construção de uma universidade pública, gratuita e de qualidade.

À colega Daniela Bertocchi por todo auxílio, paciência, generosidade e "consultorias digitais".

Aos colegas do Grupo de Pesquisa COM+ que foram fonte de inspiração para todo trabalho aqui desenvolvido. Especialmente, às sempre presentes Issaaf Karhawi e Isadora Camargo, por toda amizade e força nas horas de tensão.

Aos professores Sérgio Bairon e Pedro Sellos que tão generosamente participaram da banca de qualificação deste trabalho, contribuindo de forma fundamental para a sua realização. 
A todos meus amigos e colegas que de alguma forma contribuíram e fizeram parte desta jornada nesses últimos quatro anos.

Muito obrigada. 
The things you own end up owning you. Tyler Durden (Chuck Palahniuk, “Fight Club”) 


\section{RESUMO}

Silveira, Stefanie Carlan da. Conteúdo jornalístico para smartphones: o formato da narrativa sistêmica no jornalismo ubíquo. 2017. 223f. Tese (Doutorado) - Escola de Comunicações e Artes. Universidade de São Paulo. São Paulo, 2017.

Ao longo dos tempos, a produção de notícias e reportagens precisou se adaptar à modernização do jornal impresso, ao surgimento do rádio, da televisão, mais recentemente, à internet e, por último (por enquanto), aos dispositivos móveis digitais como smartphones e tablets. Cada um desses períodos foi marcado por novos formatos de produzir, distribuir e consumir jornalismo. Dentro deste caminho evolutivo está o objeto de pesquisa desta tese que envolve a busca por formatos narrativos que se adaptem de forma mais personalizada aos dispositivos móveis digitais, às suas características específicas e potencialidades e, ainda, ao jornalismo que se reconfigura a partir das transformações da contemporaneidade. A massiva adoção dos dispositivos móveis digitais entre o público e a evolução tecnológica criam possibilidades de formatação e distribuição jornalísticas mais interativas e ubíquas se comparadas ao que havia antes. Enquanto novos meios de comunicação, os smartphones oferecem qualidades importantes para a redefinição do consumo de informação na atualidade, entre elas estão a portabilidade, a ubiquidade e a sensibilidade ao contexto do usuário. A partir dessa compreensão, entendemos, neste trabalho, que o jornalismo e sua conceituação precisam acompanhar esse processo evolutivo, o que nos leva à adoção do conceito de jornalismo ubíquo e também à elaboração de categorias constituintes desse conceito. Em seguimento a isto, também adotamos o conceito de narrativa sistêmica para fazer parte de nossa compreensão do formato atual dos conteúdos. Esses dois conceitos se unem a uma fundamentação complementar ligada ao design de navegação e interface, à experiência do usuário e à usabilidade para investigar as características específicas do jornalismo ubíquo e do seu formato, e em que patamar está sua adoção pelos aplicativos para smartphones dos jornais The New York Times, The Guardian, El País e O Estado de S. Paulo. Ao final, expomos o momento atual desses produtos jornalísticos e suas diferentes soluções de apresentação para as potencialidades existentes a partir do desenvolvimento tecnológico.

Palavras-chave: Jornalismo ubíquo. Smartphones. Aplicativos. Jornalismo. Dispositivos móveis digitais. 


\begin{abstract}
Silveira, Stefanie Carlan da. Journalistic content for smartphones: the format of the systemic narrative in ubiquitous journalism. 2017. 223f. Tese (Doutorado) - Escola de Comunicações e Artes. Universidade de São Paulo. São Paulo, 2017.

Over the years, the news production has had to adapt itself to the modernization of the printed newspaper, to the emergence of radio, television, more recently to the internet, and finally (for now) to digital mobile devices such as smartphones and tablets. Each of these periods was marked by new formats for producing, distributing and consuming journalism. Within this evolutionary path is located the research object of this thesis that involves the search for narrative formats that adapt in a more personalized way to the digital mobile devices, their specific characteristics and potentialities and also to the journalism that is reconfigured from the transformations of the contemporaneity. The massive adoption of digital mobile devices within the public and the technological evolution create more interactive and ubiquitous possibilities of formatting and distributing journalistic media than in the past. As a new media, smartphones offer important qualities for today's information consumption redefinition, among which are portability, ubiquity, and user context sensitivity. From this understanding, we assume in this work that journalism and its conception need to accompany this evolutionary process, which leads us to adopt the concept of ubiquitous journalism and also to the elaboration of constituent categories of this concept. Following this, we also adopt the concept of systemic narrative to be part of our understanding of the current format of the contents. These two concepts are coupled with a complementary basis linked to navigation and interface design, user experience, and usability to investigate the specific characteristics of ubiquitous journalism and its format, and at what level it is adopted by the smartphone applications of the newspapers The New York Times, The Guardian, El País and $\mathrm{O}$ Estado de S. Paulo. At the end, we present the current moment of these journalistic products and their different solutions of presentation to the potentialities emerged from the technological development.
\end{abstract}

Keywords: Ubiquitous journalism. Smartphones. Applications. Journalism. Digital mobile devices. 


\section{RESUMEN}

Silveira, Stefanie Carlan da. Contenido periodístico para los teléfonos inteligentes: el formato de la narrativa sistémica en el periodismo ubicuo. 2017. 223f. Tese (Doutorado) - Escola de Comunicações e Artes. Universidade de São Paulo. São Paulo, 2017.

Con el tiempo, la producción de noticias tuvo que adaptarse a la modernización del periódico impreso, la aparición de la radio, la televisión, más recientemente, el Internet, y por último (por ahora), los dispositivos móviles digitales, como teléfonos inteligentes y tabletas. Cada uno de estos períodos estuvo marcado por nuevos formatos para producir, distribuir y consumir periodismo. Dentro de este camino evolutivo está el objeto de investigación de esta tesis que consiste en la búsqueda de formatos narrativos para adaptarse de forma más personalizada a los dispositivos móviles digitales, a sus características y potencialidades específicas, y también para el periodismo que se reconfigura a partir de las transformaciones de la sociedad contemporánea. La adopción masiva de dispositivos móviles digitales entre el público y los desarrollos tecnológicos crean posibilidades de distribución de noticias más interactivas y ubicuas en comparación con lo que había antes. Como nuevos medios de comunicación, los teléfonos inteligentes ofrecen cualidades importantes para la redefinición de consumo de información en la actualidad, entre ellas se encuentran la portabilidad, la ubicuidad y la sensibilidad al contexto del usuario. A partir de este conocimiento, creemos en este trabajo que el periodismo y su conceptualización deben seguir este proceso evolutivo lo que nos conduce a la adopción del concepto de periodismo ubicuo y también la preparación de las categorías constitutivas del concepto. En seguimiento a esto, también adoptamos el concepto de narrativa sistémica a ser parte de nuestra comprensión del actual formato del contenido. Estos dos conceptos están unidos a un conjunto de razones adicionales relacionados con el diseño de la interfaz y de la navegación, la experiencia de usuario y usabilidad para investigar las características específicas del periodismo ubicuo y el nivel de su adopción por las aplicaciones para teléfonos inteligentes de los periódicos The New York Times, The Guardian, El País y O Estado de S. Paulo. Por último, se explica la situación actual de estos productos periodísticos y sus diferentes soluciones de presentación al potencial existente de desarrollo tecnológico.

Palabras clave: Periodismo ubicuo. Teléfonos inteligentes. Aplicaciones. Periodismo. Dispositivos móviles digitales. 


\section{Nota aos leitores}

Optamos por seguir as diretrizes para apresentação de dissertações e teses da Universidade de São Paulo (USP), de acordo com a Associação Brasileira de Normas Técnicas (ABNT), segundo Funaro et al. (2016) ${ }^{1}$ para a elaboração e formatação desta tese doutoral.

Os termos estrangeiros, neste trabalho, são apresentados no formato itálico, mesmo aqueles que já se encontram incorporados aos dicionários de Língua Portuguesa. Quanto às citações em língua estrangeira, elas receberam livre tradução desta autora no corpo da tese. Por sua vez, os textos originais foram alocados em notas de rodapé, e as citações retiradas de obras portuguesas são apresentadas na forma original de suas publicações.

Siglas e termos técnicos encontram-se em lista específica para um melhor entendimento à leitura deste trabalho.

Escolhemos apresentar este trabalho em folhas (f.), ou seja, somente no anverso da página e não em anverso e verso das páginas.

\footnotetext{
${ }^{1}$ FUNARO, V.M.B.O. (Coord.) et al. Diretrizes para apresentação de dissertações e teses da USP: parte I (ABNT)/Sistema Integrado de Bibliotecas da USP. 3. ed. rev. ampl. mod. São Paulo: SIBiUSP, 2016. 100p. (Cadernos de estudos; 9)
} 


\section{LISTA DE ILUSTRAÇÕES}

Figura 1 - Esquema gráfico da pesquisa doutoral ............................................. 33

Figura 2 - Estágios de evolução do jornalismo ................................................. 71

Figura 3 - O Sistema narrativo no jornalismo digital ........................................ 100

Figura 4 - Esquema do ecossistema móvel ............................................. 106

Figura 5 - Elementos de projetos de experiência do usuário ................................. 136

Figura 6 - Roteiro de avaliação do design na camada esqueleto .............................. 139

Figura 7 - Tela inicial do aplicativo do NYT para smartphones Android ................... 146

Figura 8 - Elementos de personalização e redistribuição no app do NYT ................... 148

Figura 9 - Visão interna de um artigo aberto no aplicativo do NYT ....................... 150

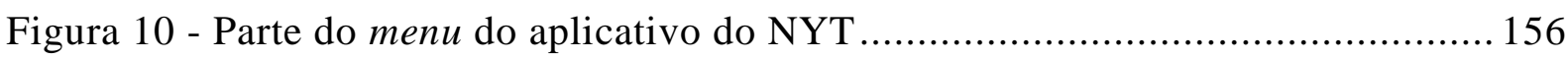

Figura 11 - Página inicial do app do Guardian .................................................... 160

Figura 12 - Cobertura em tempo real no app do Guardian ...................................... 162

Figura 13 - Artigos relacionados e tags ao final do texto no app do Guardian............ 163

Figura 14 - Recurso de seguir profissionais no app do Guardian ............................ 164

Figura 15 - Uso de algoritmos para recomendações no app do Guardian ................... 165

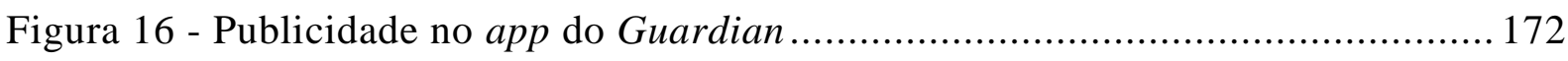

Figura 17 - Tela inicial do aplicativo do El País............................................ 175

Figura 18 - Infográfico não adaptado para o dispositivo móvel no app do El País ...... 180

Figura 19 - Menu do app do El País na edição espanhola ........................................ 181

Figura 20 - Publicidade no app do El País ............................................................ 184

Figura 21 - Aplicativo do Estadão para smartphones ....................................... 187

Figura 22 - Recurso para continuar a leitura no app do Estadão ............................. 192

Figura 23 - Menu do app do Estadão acessível pela tela inicial .............................. 193

Figura 24 - Мепи do app do Estadão acessível em telas secundárias ........................ 193

Figura 25 - Tela de erro no aplicativo do Estadão................................................... 195

Figura 26 - Links patrocinados exibidos ao final dos artigos no app do Estadão ......... 199 


\section{LISTA DE QUADROS}

Quadro 1 - Propriedades do Jornalismo Ubíquo................................................. 133

Quadro 2 - Propriedades do formato narrativo sistêmico para smartphones no JU ...... 134

Quadro 3 - Categorias de análise do formato narrativo no Jornalismo Ubíquo

(Instrumento 1 de observação) ................................................... 135

Quadro 4 - Categorias de análise da interface e navegação dos aplicativos ................. 143 


\section{LISTA DE TABELAS}

Tabela 1 - Avaliação 1 do app do NYT. 151

Tabela 2 - Análise do Design de Navegação do app do NYT 153

Tabela 3 - Avaliação do Design de Interface do app do NYT 154

Tabela 4 - Avaliação 1 do app do Guardian 167

Tabela 5 - Análise do Design de Navegação do app do Guardian 168

Tabela 6 - Avaliação do Design de Interface do app do Guardian. 169

Tabela 7 - Avaliação 1 do app do El País..... 178

Tabela 8 - Análise do Design de Navegação do app do El País 182

Tabela 9 - Avaliação do Design de Interface do app do El País 183

Tabela 10 - Avaliação 1 do app do Estadão 189

Tabela 11 - Análise do Design de Navegação do app do Estadão 196

Tabela 12 - Avaliação do Design de Interface do app do Estadão 197

Tabela 13 - Adoção das categorias do JU nos principais aplicativos das marcas

Tabela 14 - Avaliação dos designs de Navegação e Interface dos principais aplicativos das marcas. 


\section{LISTA DE GRÁFICOS}

Gráfico 1 - Representação das categorias do JU no app do NYT

Gráfico 2 - Representação da Análise do Design de Navegação no app do NYT . 154

Gráfico 3 - Representação da Análise do Design de Interface do app do NYT 155

Gráfico 4 - Representação das categorias do JU no app do Guardian 167

Gráfico 5 - Representação da Análise do Design de Navegação no app do Guardian 169

Gráfico 6 - Representação da Análise do Design de Interface do app do Guardian .... 170

Gráfico 7 - Representação das categorias do JU no app do El País .......................... 178

Gráfico 8 - Representação da Análise do Design de Navegação no app do El País ..... 182

Gráfico 9 - Representação da Análise do Design de Interface do app do El País ........ 183

Gráfico 10 - Representação das categorias do JU no app do Estadão......................... 189

Gráfico 11 - Representação da Análise do Design de Navegação no app do Estadão .. 196

Gráfico 12 - Representação da Análise do Design de Interface do app do Estadão ..... 197

Gráfico 13 - Adoção das categorias do JU nos principais aplicativos das marcas........ 201

Gráfico 14 - Avaliação dos Designs de Navegação e Interface dos principais aplicativos

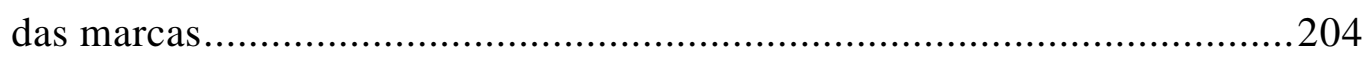




\section{LISTA DE SIGLAS E TERMOS TECNOLÓGICOS}

Alertas $24 / 7$

Analytics

Android

ANT

$A P I$

$A P$

App

Arpa

Big data

Cetic.br

CGI.br

CMS

Conexão $3 G$

Conexão $4 G$

Dataentry

Datastream

Desktop site

Download

e-readers

Features

Front-end e backend

Full HD

Ghz
Monitoramento ao vivo de terremotos, tsunami, meteoros, acidentes, emergências, desastres, terrorismo entre outros

Descoberta e análise de padrões significativos nos dados

Sistema operacional para dispositivos móveis

Actor-Network Theory (Teoria Ator-Rede)

Application Programming Interface (interface de programação de aplicativos)

Associated Press

Application ou Software Application (aplicação, aplicativo ou software aplicativo)

Advanced Research Projects Agency

Grande volume de dados, voláteis ou não, com maior velocidade e escaláveis

Centro Regional de Estudos para o Desenvolvimento da Sociedade da Informação

Comitê Gestor da Internet no Brasil

Content Management System (sistema de gerenciamento de conteúdos)

Terceira geração de padrões e tecnologias de telefonia móvel

Quarta geração de padrões e tecnologias de telefonia móvel

Interface digital para entrada de dados

Fluxo de dados

Site para serem acessados via computador de mesa

Obtenção de conteúdo da Internet

Leitor de livros digitais, tais como o Kindle, da Amazon

Características, funcionalidades

Em sistemas de gerenciamento de conteúdo, os termos front-end e back-end podem se referir às visões do usuário final do SGC e às visões administrativas, respectivamente. Em termos gerais, frontend é a parte que se vê do código que está no back-end.

Full High Definition (Máxima Alta Definição)

Gigahertz 
HTML

HTML 5

Input/Output

$i O S$

IxD

$J D B D$

J.U.

Mashups

MMS

Mobile first

Mobile Site

NIC.br

Octa-Core

Ombudsman

Paywall

PARC

PC

$P D F$

Plugins, plug-in, Programa de computador usado para adicionar funções a outros add-in ou add-on

QR code

Hyper Text Markup Language (linguagem de marcação para criação de sites web)

Hyper Text Markup Language 5 (quinta versão da linguagem HTML)

Entrada e saída de dados

iPhone OS (sistema operacional para dispositivos móveis da Apple Inc.)

Interaction Design (design de interação)

Jornalismo Digital de Base de Dados

Jornalismo Ubíquo

Aplicação web que usa códigos de terceiros e dados de fontes distintas

Multimedia Messaging Service (serviço de mensagens multimídia)

Conceito aplicado em projetos web onde o foco inicial da arquitetura e desenvolvimento é direcionado aos dispositivos móveis e em seguida para os desktops

Sites para serem acessados via dispositivos móveis, como celulares e tablets

Núcleo de Informação e Coordenação do Ponto BR

Processador dividido em oito núcleos

Profissional contratado por um órgão, instituição ou empresa com a função de receber críticas, sugestões e reclamações de usuários e dever agir de forma imparcial para mediar conflitos entre as partes envolvidas. No jornalismo, o ombudsman tem a função de agir como avaliador crítico do produto da empresa oferecido ao público.

Sistema de assinatura usado por jornais e outros veículos de comunicação digitais que permite ao internauta o acesso a conteúdos restritos

Laboratório de Ciência da Computação no Centro de Pesquisa da Xerox

Computadores pessoais

Portable Document Format (formato de documento transportável) programas maiores

Quick Response (é um código de barras bidimensional que pode 


$\begin{array}{ll}\text { RFID } & \begin{array}{l}\text { ser escaneado usando um smartphone que contenha câmera) } \\ \text { Radio Frequency Identification Device (Dispositivo de } \\ \text { identificação por radiofreqüência) } \\ \text { RSS }\end{array} \\ \text { REM } & \begin{array}{l}\text { Seally Simple Syndication (sindicância de conteúdos) } \\ \text { de busca }\end{array} \\ \text { SEO } & \begin{array}{l}\text { Search Engine Optimization (otimização de sites para motores de } \\ \text { busca) } \\ \text { SGC }\end{array} \\ \text { Smartphone } & \text { Sistema de Gerenciamento de Conteúdos } \\ \text { SMS } & \text { Telefone móvel com funcionalidades computacionais avançadas } \\ \text { Short Messaging Service (serviços de envio de mensagens de texto } \\ \text { curtas) }\end{array}$

Computer software

Tablet ou tablet Dispositivo móvel de médio porte computer

Tag

Etiqueta, metadado, palavra-chave

Tagging

Tagueamento, etiquetamento

TAR

Actor-Network Theory (Teoria Ator-Rede)

Template

Modelo

$T G S$

Teoria Geral dos Sistemas

$T I$

Tecnologia da Informação

TICs

Tecnologias da Informação e Comunicação

TIC Domicílios

Tecnologias da Informação e Comunicação nos Domicílios Brasileiros

$U R L$

Uniform Resource Locator (endereço eletrônico)

$U X$

User Experience (experiência do usuário)

$U X D$

User Experience Design (desenho da experiência do usuário)

WAP

Wireless Application Protocol (Protocolo para Aplicações sem Fio)

Wearable Vestível ou usável (tecnologias vestíveis)

Web of data Web dos dados

Web of documents Web dos documentos

Web of things Web das coisas 
$W W W$

$X M L$
World Wide Web ou apenas Web (sistema de documentos em hipermídia interligados e executados na internet)

eXtensible Markup Language (linguagem de marcação para criação de sites web) 


\section{SUMÁRIO}

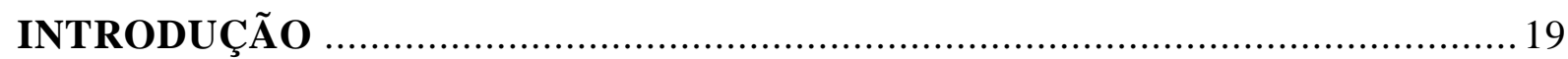

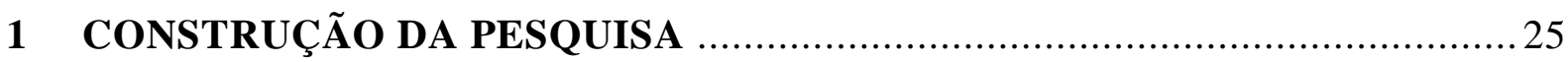

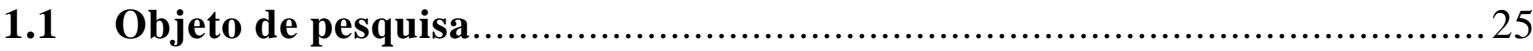

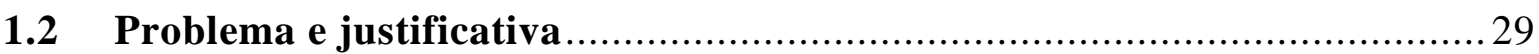

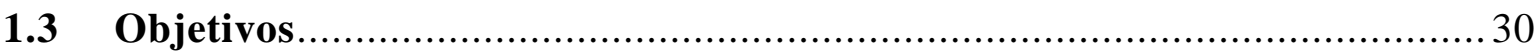

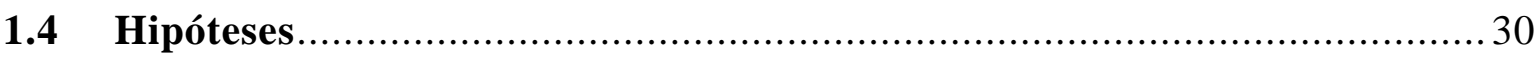

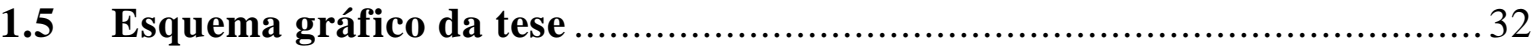

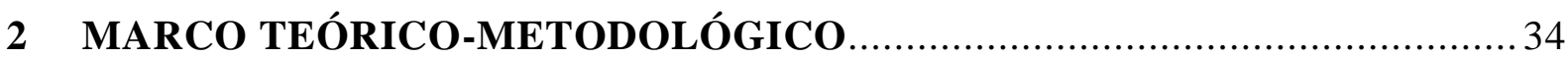

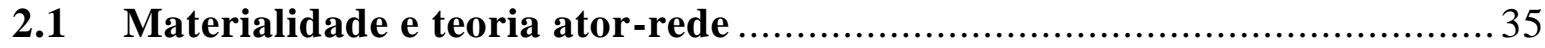

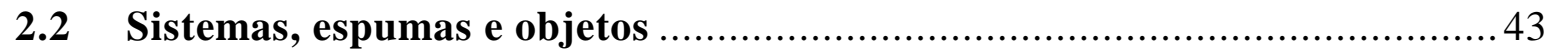

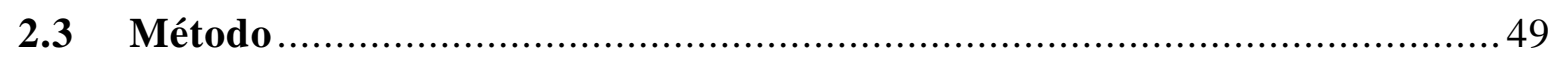

3 DISPOSITIVOS MÓVEIS E JORNALISMO UBÍQUO …...............................52

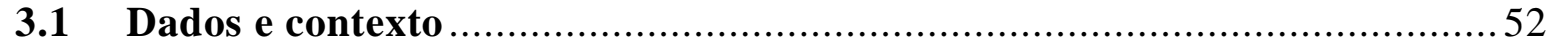

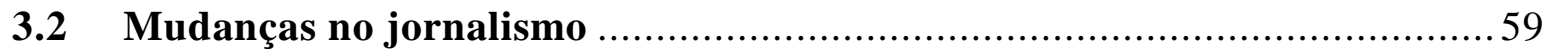

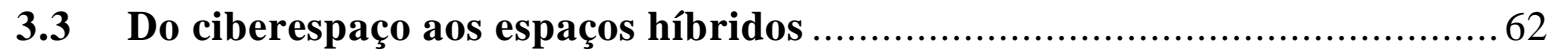

3.4 Do jornalismo móvel ao jornalismo ubíquo …….........................................69

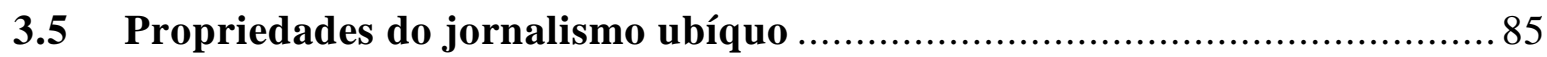

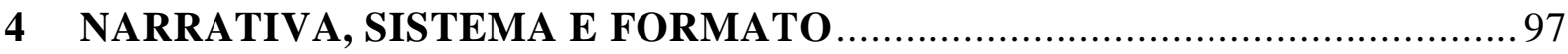

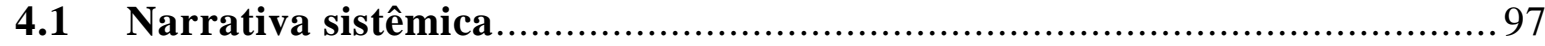

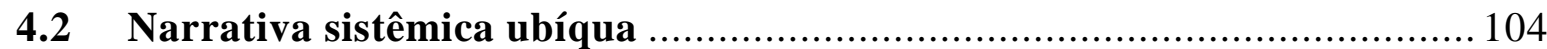

4.3 Características do formato do jornalismo ubíquo em smartphones .......... 122

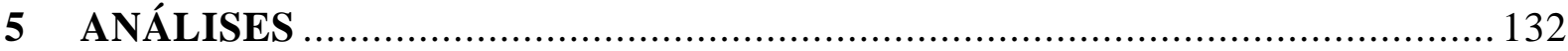

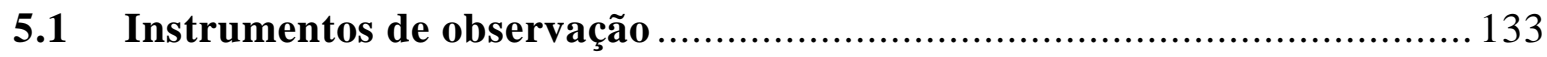

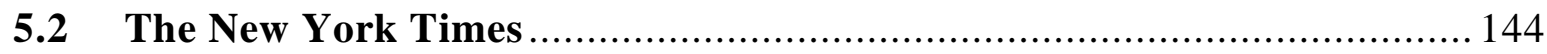

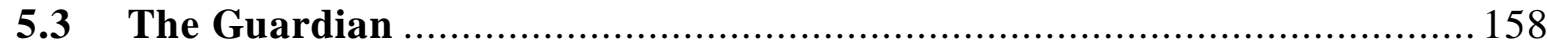

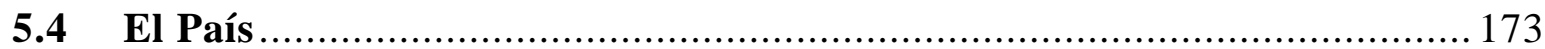

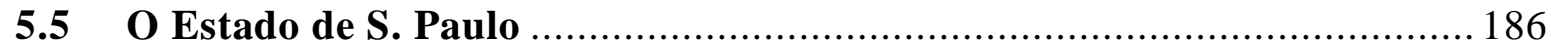

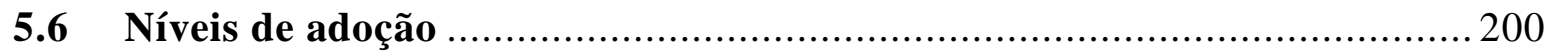

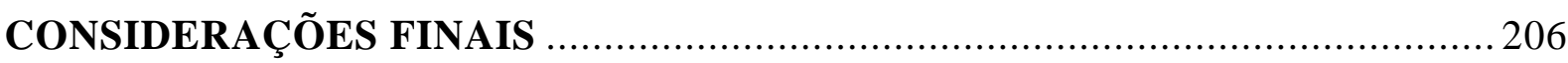

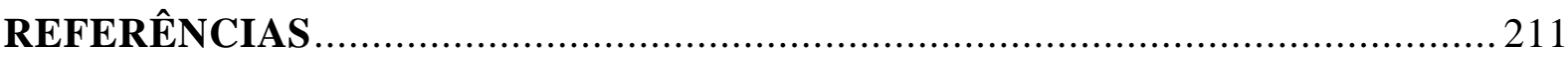




\section{INTRODUÇÃO}

O jornalismo está em crise. Embora clichê, essa frase é parte fundante do contexto no qual realizamos este trabalho de pesquisa doutoral. O jornalismo, enquanto instituição, enfrenta há pelo menos 20 anos uma crise que envolve o ajuste dessa instituição às novas configurações tecnológicas e culturais do século XXI. Há um desajuste financeiro, no modelo de negócios, nas rotinas de produção, nos processos de distribuição, no formato de apresentação do produto jornalístico e, também, na representatividade e reconhecimento da profissão dentre os novos consumidores. As gerações mais recentes vivem num contexto profundamente transformado nos aspectos econômicos, sociais e políticos, fazendo com que muitas pessoas não se sintam representadas pelas instituições que antes construíam nossa visão de coletividade democrática. O jornalismo é uma das instituições que enfrentam esse problema associado a um processo de evolução tecnológica que vem afetando toda a indústria de produção de conteúdo, seja ela jornalística ou de entretenimento.

Reig (2015) coloca que a crise atual do jornalismo não pode ser confundida com um reflexo da crise econômica de 2008, justificativa utilizada por muitas empresas jornalísticas para fundamentar demissões e cortes em seus produtos. Segundo o autor, a crise do jornalismo existe desde o momento em que o jornalismo tropeçou "em vários Ps".

[...] P de Propriedade dos meios de produção da notícia, P de Publicidade, o P da influência Política, o P de Produção da notícia sobre a base de redações passivas nas quais "se esquece" de sair para a rua e buscar notícias próprias e transgressoras. O P de Públicos que vão buscando aquilo que desejam ouvir e não aquilo que acontece. E mesmo o $\mathrm{P}$ de Periodismo na forma de jornalistas mais próximos das suas empresas e dos lobbies do poder do que do jornalismo (REIG, 2015, p. 11) ${ }^{2}$.

Apenas um trabalho de tese doutoral não é capaz de dar conta de todos os elementos que compõem esse período de ajustes e transformações pelo qual passa o jornalismo, por isso, escolhemos uma parte desse cenário para realizar nossa investigação. Um dos elementos que afetam atualmente as empresas jornalísticas e seu

\footnotetext{
${ }^{2}$ Tradução da autora, a palavra 'periodismo' foi mantida para que o texto do autor não perdesse o sentido. Trecho original: “[...] la P de Propiedad de los medios de producción de la noticia, la P de Publicidad, la P de la influencia Política, la P de Producción de la noticia sobre la base de redacciones pasivas a las que "se les olvida" salir a la calle a buscar noticias propias y transgresoras. La P de Públicos que van buscando aquello que desean oír y no aquello que sucede. Y la misma P de Periodismo en forma de periodistas más cercanos a sus empresas y a lobbies de poder que al Periodismo".
} 
público consumidor são os novos formatos de apresentação do conteúdo produzido por seus profissionais. Ao longo dos tempos, a produção de notícias e reportagens precisou se adaptar à modernização do jornal impresso, ao surgimento do rádio, da televisão, mais recentemente, à internet e, por último (por enquanto), aos dispositivos ${ }^{3}$ móveis digitais como smartphones e tablets. Cada um desses períodos foi marcado por novos formatos de produzir, distribuir e consumir jornalismo.

Salaverría (2016b) explica que a evolução do jornalismo digital nos países iberoamericanos sempre esteve condicionada ao próprio desenrolar do desenvolvimento tecnológico junto à população nesses locais. Nos últimos anos, um dos principais avanços foi obtido a partir da conexão móvel $3 \mathrm{G}$ e $4 \mathrm{G}$ que ampliou o acesso em diversos países, alguns deles com mais linhas do que habitantes.

A presença dos dispositivos móveis digitais na distribuição de conteúdo jornalístico não é tão recente. No começo do surgimento dos aparelhos no mercado, as empresas jornalísticas passaram a enviar pequenos conteúdos por SMS e MMS a usuários que se cadastrassem e/ou pagassem para receber tais mensagens. Alguns dos serviços mais comuns, por exemplo, eram alertas relacionados a esportes e previsão do tempo. Esse fenômeno de consumo de informação pelo celular, até então limitado por condições técnicas, começou a ganhar mais força, efetivamente, com a chegada dos smartphones, da conexão 3G (mais rápida) e dos aplicativos próprios para esses artefatos. O lançamento do primeiro iPhone, em 2007, pela Apple, pode ser considerado um marco nesse processo, pois serviu como estímulo para o desenvolvimento de outros modelos de smartphones e também do sistema operacional Android, atualmente o mais

\footnotetext{
3 Ao utilizarmos o termo dispositivo neste trabalho não buscamos sugerir uma discussão ligada ao significado do termo proposto por Foucault. Não temos como dar conta, neste espaço, de uma discussão acerca das estratégias, relações de força, condicionamentos, governabilidade e poder envolvendo os dispositivos móveis digitais e ubíquos. Nosso uso aqui é muito mais dentro de um significado tecnológico, visto como o "modo em que estão dispostas as partes de uma máquina ou de um mecanismo e, por extensão, o próprio mecanismo" (AGAMBEN, 2009, p.34). Obviamente que, como propõe o próprio Agamben, esta ideia tecnológica faz parte da amplitude do conceito proposto por ele. O autor afirma: "chamarei literalmente de dispositivo qualquer coisa que tenha, de algum modo, a capacidade de capturar, orientar, determinar, interceptar, modelar, controlar e assegurar os gestos, as condutas, as opiniões e os discursos dos seres viventes" (p. 40). Agamben dá o exemplo do telefone celular enquanto algo que pode ser chamado de dispositivo dentro da definição proposta por ele. Ou seja, o telefone celular é um dispositivo, no entanto, não damos conta da discussão relacionada ao biopoder destes dispositivos. Isso não quer dizer que tomamos aqui o dispositivo enquanto algo inerte, técnico e inoperante no relacionamento comunicacional. Bem diferente disso, como pode ser visto no capitulo 2, temos uma visão de dispositivo enquanto algo ativo na relação de comunicação. O que se quer dizer aqui é que não seremos capazes de dar conta das relações de poder integrantes do dispositivo que tratamos neste trabalho, por isso, pedimos ao leitor que, ao fazer a leitura do termo, tenha em mente que estamos nos limitando ao significado tecnológico, à tradução da palavra inglesa device, usada como sinônimo de artefato, mas ainda assim dentro de um contexto ativo e participante do processo comunic acional.
} 
utilizado no mundo. Até então, os telefones celulares que se aproximavam de uma ideia de smartphone, como os Blackberry, tinham uma interface que tentava imitar a interface do computador pessoal. Ao apresentar o iPhone, a Apple também apresentou uma nova lógica de interação com o aparelho, uma lógica própria e personalizada, que levava em conta as características e potencialidades do dispositivo, não mais se remetendo a uma metáfora anterior.

\begin{abstract}
Além de continuar buscando maturidade, o ciberjornalismo de hoje em dia se vê frente a uma situação que nos remete ao seu surgimento há vinte anos. De maneira similar a como a web chegou para causar uma ruptura nos modelos tradicionais de distribuição de notícias e informações, agora vemos um enorme impacto dos dispositivos móveis, que estão substituindo os computadores. Os móveis afetam o jornalismo da web da mesma maneira que este afetou os meios tradicionais (ALVES, 2016, p. XIV) ${ }^{4}$.
\end{abstract}

Obviamente, todo processo de ruptura e transformação parte de referências anteriores, na medida em que são os pontos de apoio comuns aos atingidos pelo processo. É o que Bolter e Grusin (2000) chamam de remediação, onde os meios antigos se reconfiguram a partir dos novos e os novos partem de um referencial já existente.

Jarvis (2015) afirma que sempre definimos o futuro nos termos do passado. Toda a vez que uma nova tecnologia nasce, nós tendemos a compará-la com a anterior e tentamos fazer com que opere a partir dos modelos de funcionamento aos quais estávamos acostumados. Nesse momento, podemos considerar que estamos diante de um novo ecossistema midiático que está transformando o cenário anteriormente dominante de processos verticalizados de comunicação. Esse novo ecossistema é composto por novas companhias, $\operatorname{blog} s$, mídia independente e outros produtores de conteúdo. É com relação a este contexto que o jornalismo precisa inovar e encontrar caminhos disruptivos dentro das empresas de comunicação. Dentro desse caminho evolutivo está a busca por formatos narrativos que se adaptem de forma mais personalizada aos dispositivos móveis digitais, às suas características específicas e potencialidades, bem como ao jornalismo que se reconfigura a partir das transformações da contemporaneidade.

\footnotetext{
${ }^{4}$ Tradução da autora, trecho original: "Además de continuar buscando la madurez, el ciberperiodismo se ve hoy día frente a una situación que nos recuerda su aparición hace veinte años. De manera similar a como la web llegó para causar una ruptura de los modelos tradicionales de distribución de noticias e informaciones, ahora vemos el enorme impacto de los dispositivos móviles, que están reemplazando a las computadoras. Los móviles afectan al periodismo de la web, del mismo modo en que este ha afectado a los medios tradicionales".
} 
A forte adoção dos dispositivos móveis digitais ${ }^{5}$ entre o público consumidor e também a evolução da internet das $\operatorname{coisas}^{6}$ cria possibilidades de formatação e distribuição jornalísticas mais interativas e ubíquas se comparadas ao que havia antes. Enquanto novos meios de comunicação, os smartphones oferecem qualidades importantes para a redefinição do consumo de informação na atualidade. Entre elas estão a portabilidade, a ubiquidade e a sensibilidade ao contexto do usuário. A sensibilidade ao contexto é um dos aspectos mais novos e relevantes nesse processo, na medida em que leva em consideração a localização do usuário, seus hábitos de uso e interesses pessoais (WOLF; SCHNAUBER, 2015).

Wolf e Schnauber (2015) conduziram uma pesquisa na Alemanha para compreender a importância desses fatores para o público consumidor de notícias. Os resultados mostram que, entre os entrevistados, a maioria considera de grande importância as possibilidades de acessar notícias em qualquer lugar, horário e também de receber alertas 24/7 diretamente em seus dispositivos.

\begin{abstract}
A situação e as atividades antes e durante a recepção variam, ao passo que os dados mostram que as plataformas tradicionais são usadas em circunstâncias bastante estáveis. O uso do computador cai de alguma forma no meio, mas ainda é menos flexível quando comparado ao uso do dispositivo digital. Pelo presente, o uso do dispositivo móvel se difere significativamente de todas as outras plataformas (WOLF; SCHNAUBER, 2015, p. 10) ${ }^{7}$.
\end{abstract}

Os entrevistados do estudo citado acima também apontam como principais fontes de informação consumida no celular os sites de dois jornais tradicionais da Alemanha e da maior rede de televisão. Segundo o estudo, mais de $60 \%$ das fontes de informação mencionadas pelos pesquisados fazem parte de marcas tradicionais de mídia que, atualmente, dominam o cenário de produção de conteúdo jornalístico multiplataformas.

Em adição à ideia de que o uso do dispositivo móvel digital é mais flexível que o do computador pessoal, Dimmick et al. (2011), apresenta os aspectos do uso "on-the-go"

\footnotetext{
${ }^{5}$ A pesquisa apresenta dados que comprovam esta afirmação no item 3.2.

${ }^{6}$ Segundo Singer (2012), internet das coisas (internet of things) é um termo genérico que desde "sua primeira aparição em 1999 (ASHTON, 1999) até os dias atuais é usado para designar processos que envolvam objetos conectados em rede e que produzam e/ou processem informação em tempo real e de forma autônoma" (p. 2). O termo é usado para designar a automação e conexão das "coisas", como, por exemplo, carros, geladeiras, relógios, sistemas elétricos, assistentes pessoais baseados em inteligência artificial etc. O termo é mais amplamente explorado no item 3.5 deste trabalho.

7 Tradução da autora, trecho original: "The situation and activities before and during reception vary, whereas the data show that traditional platforms are used in quite stable circumstances. Computer use falls somewhat in-between but is still less flexible in use compared to mobile device use. Hereby, mobile device use differs significantly from all other platforms".
} 
e "in-between", o que significa que a utilização pode ser feita em movimento e também durante ou entre alguma outra tarefa. Isso tudo quer dizer que a presença e adoção dos smartphones criam espaços para produção jornalística não existentes anteriormente, ou ainda, se existentes, não potencializados e personalizados como neste momento.

Sendo assim, é a partir dessas noções, afirmações e descobertas que construímos nossa investigação. Nossos primeiros passos de pesquisa estão expostos a seguir, no primeiro capítulo do trabalho. Nele detalhamos nosso objeto de pesquisa, a problemática que nos guia na investigação, os objetivos que buscamos atender ao longo do trabalho e as hipóteses que foram construídas, a fim de serem verificadas ao final da trajetória. Em seguida, para que pudéssemos fundamentar nosso trabalho e também buscar instrumentos que nos auxiliassem em nossa observação e análise, dividimos a pesquisa em outros quatro capítulos.

O segundo capítulo apresenta nosso marco teórico-metodológico de pesquisa. Nele trazemos as contribuições da Teoria Ator-Rede, materialidade da comunicação, Teoria dos Sistemas e metáfora das espumas como conjunto teórico que abriga o nosso olhar em direção ao objeto de pesquisa. É a partir desse lugar apresentado neste item que observamos e construímos nossa investigação, acreditando que este construto nos fornece elementos e embasamento sólido para defender as escolhas que fazemos ao longo da tese e ao longo da análise do objeto.

No terceiro capítulo, adentramos mais a fundo a realidade do nosso objeto de pesquisa, trazendo dados que ajudam o leitor a conhecer o cenário contemporâneo da comunicação, do jornalismo e do consumo de conteúdo. Além disso, é também neste item que expomos um dos conceitos fundamentais para a realização deste trabalho: o jornalismo ubíquo. O termo apresentado pelo professor Ramón Salaverría (2016a) abarca a noção de reconfiguração aos processos de produção, distribuição e consumo que exploramos aqui. Nesse sentido, também buscamos acrescentar ao conceito uma série de categorias que fazem parte da sua constituição e ajudam a definir o tipo de jornalismo que se apresenta daqui para frente.

No quarto capítulo, trazemos mais um dos conceitos essenciais desta pesquisa, o de narrativa sistêmica, criado pela autora Daniela Bertocchi (2014). É a partir da ideia trazida pela pesquisadora que buscamos a compreensão de um formato narrativo próprio e adequado ao jornalismo ubíquo. Aqui também buscamos apresentar uma série de 
categorias que nos ajudam a visualizar e compreender este formato do qual estamos falando.

Por último, o quinto capítulo desta pesquisa apresenta nossa ida a campo e nossa aproximação ao objeto empírico da pesquisa. Nele, expomos toda a construção de nossos instrumentos de observação utilizados para a abordagem do objeto e também as análises realizadas a partir desta ação. Item a item, trazemos os dados coletados junto aos nossos quatro focos de pesquisa: os aplicativos para smartphone dos jornais The New York Times, The Guardian, El País e O Estado de S. Paulo. Após a exposição dos dados e sua consequente problematização e contextualização, finalizamos o trabalho com nossas considerações finais, esperando ter contribuído efetivamente ao campo da Comunicação e da Pesquisa na área do Jornalismo. 


\section{CONSTRUÇÃO DA PESQUISA}

A área de concentração deste trabalho doutoral aborda a comunicação como um campo de conhecimento inter e transdisciplinar. Nesse sentido, as propostas expostas nesta tese defendem um olhar contemporâneo para o campo da comunicação, levando em consideração seu hibridismo e a constante atualização de seus objetos. Dentro da área do Programa de Pós-Graduação da Universidade de São Paulo, buscou-se a linha de pesquisa mais adequada aos questionamentos propostos no trabalho e, sendo assim, optou-se por Comunicação e Ambiências em Redes Digitais.

A linha propõe a reflexão sobre as complexidades que atingem o campo da comunicação com as influências das tecnologias de informação e comunicação. Nesse mesmo âmbito, este trabalho se propõe a buscar respostas para as questões que afetam o jornalismo com os impactos ${ }^{8}$ dos dispositivos móveis digitais. Com um objeto bastante atual, leva em conta a observação de questões como centralidade, transversalidade e resiliência dentro do seu campo de pesquisa (CORRÊEA, 2015).

A proposta aqui apresentada também está de acordo com os temas que dizem respeito aos estudos da evolução tecnológica e seus impactos nas organizações e às transformações dos estudos sobre mobilidade e ubiquidade no jornalismo. Isso porque se tratam especificamente de questões teóricas que envolvem a comunicação contemporânea, a produção e a apresentação de conteúdos jornalísticos em dispositivos móveis digitais e também da práxis destas questões.

\subsection{Objeto de pesquisa}

Dentro do contexto de profundas transformações do qual falamos na Introdução deste trabalho, focamos nossos esforços na investigação de um objeto específico: os formatos narrativos sistêmicos e jornalísticos para dispositivos ubíquos. Isso quer dizer que temos por objetivo investigar a apresentação dos produtos jornalísticos

\footnotetext{
${ }^{8}$ Não utilizamos a palavra impacto com uma ideia determinista de que as tecnologias causam um impacto sobre os sujeitos numa posição em que um está acima do outro, ou seja, em que as tecnologias geram e os sujeitos sofrem. A palavra impacto surge para enfatizar a transformação causada, mas é utilizada com a noção de que nenhuma das partes causa e a outra sofre o impacto, ou ainda as transformações que surgem na coletividade são resultados das interações sujeito-objeto.
} 
especificamente nos smartphones, partindo do princípio que esta apresentação visível na interface do dispositivo reflete e concretiza o formato da narrativa digital, esta considerada sistêmica a partir da definição proposta por Bertocchi (2014). Sendo assim, o formato designa o desenho informático da informação e este é considerado sistêmico, pois envolve uma série de elementos interdependentes e que atuam conjuntamente em momentos anteriores e posteriores à publicação do conteúdo narrativo. Pela utilização do termo formato, queremos designar a questão da apresentação e construção do conteúdo e a interação proposta com o sujeito no ato de leitura. Ou seja, há uma tendência evolutiva da indústria jornalística e dos comportamentos de consumo do público que exigem um formato narrativo sistêmico e específico para este momento.

O foco nessa opção dá-se em função da característica cada vez mais ubíqua da comunicação contemporânea que se utiliza de dispositivos como smartphones e tablets, a cada ano mais difundidos entre a população, para produzir e distribuir conteúdo, entre outras tantas atividades. O jornalismo precisa estar em consonância com os artefatos adotados pelo público para conexão, interação e múltiplos usos e, para isso, precisou criar aplicativos e softwares para apresentação de seus produtos. Esse novo tipo de distribuição e apresentação de conteúdo, no entanto, demanda formatos específicos de configuração do produto jornalístico, tanto nas etapas de produção quanto na etapa de entrega ao público. Esta última focada em específico dentro desta pesquisa.

A narrativa, a partir de seus pressupostos básicos e clássicos, é dada como o ato de dar a conhecer histórias e fatos, não se constituindo como um gênero discursivo, pois ocorre em etapa anterior ao gênero na construção textual. No contexto da comunicação contemporânea, digitalizada e ubíqua, a narrativa ganha características diferentes que estão diretamente ligadas aos dispositivos para os quais é criada e apresentada. Assim, inclui-se em sua conceituação a noção de sistema, por ser constituída a partir de dados organizados em camadas informativas, dentro de bases de dados, organizadas por palavras-chave e até mesmo linguagens de programação como algoritmos (BERTOCCHI, 2014).

Em sua tese doutoral, Bertocchi (2014) apresenta uma proposta de modelo teórico do sistema narrativo para o jornalismo digital, baseado nas considerações supracitadas, avançando no conceito da narratologia clássica e expandindo a noção de narrativa para um agenciamento entre jornalistas, sistemas, softwares, programadores, engenheiros, designers, algoritmos, entre outros. Nesse sentido, a autora explica a antenarrativa, 
processo que ocorre durante o momento de criação do que irá chegar ao usuário ${ }^{9}$. Nesta pesquisa, a proposta é focarmos no momento posterior ao da antenarrativa, ou seja, naquele em que os formatos são visualizados pelo leitor.

A parte da narrativa visível ao usuário se apresenta num determinado formato através da interface digital. Este é afetado em função das características específicas do dispositivo no qual está sendo exposto, variando entre computadores pessoais, smartphones e tablets. Ou seja, a construção de um produto jornalístico se dá a partir da formação narrativa do texto (texto aqui sendo compreendido no sentido amplo da palavra, englobando imagem e caracteres escritos) dentro de um sistema que se interrelaciona com bases de dados e algoritmos para chegar a uma configuração final.

Uma vez que a narrativa se constitui como sistêmica, ou seja, é influenciada e composta por diversas camadas e agentes, podemos perceber que nos dispositivos ubíquos essas camadas se apresentam de forma diferente. Isso quer dizer que num computador pessoal, por exemplo, um conteúdo visualizado depende do navegador, da conexão e da sua antenarrativa. Já no smartphone, o formato do conteúdo depende da conexão, do aplicativo, do navegador, do local onde a pessoa está no momento, do modelo do celular, do contexto no qual o conteúdo é acessado, entre outros fatores. $\mathrm{Ou}$ seja, no dispositivo móvel digital a equação é composta por diferentes elementos, o que destaca, especificamente o foco do nosso trabalho que nasce no momento em que se visualiza essa complexificação das camadas narrativas e a importância do artefato em si para a formatação. Dessa forma, podemos depreender que o dispositivo atua também como mediador do processo e interfere na constituição narrativa na medida em que é um actante não humano na relação, igualmente relevante.

Com isso, temos os objetos empírico e teórico da pesquisa. Empiricamente, há o contexto atual vivido pela indústria jornalística em que a tecnologia e também o

\footnotetext{
9 Da mesma forma como fazemos uma opção conceitual com relação à palavra dispositivo para este trabalho, também o fazemos com relação ao termo usuário. Assim como não cabe nesta pesquisa a discussão acerca das relações de poder envolvidas no dispositivo móvel digital, também não cabe a discussão sobre qual termo é o mais adequado para tratar do sujeito que se envolve no processo comunicacional dentro da rede. Sabemos que a palavra usuário carrega consigo uma série de preconceitos por ser um termo adotado pelo mercado, por poder ser definido somente como "aquele que usa" sem a ideia de ação ativa por parte do receptor, entre outros. No entanto, sem pré-conceitos ou "prédefinições", o termo usuário é usado aqui para indicar o consumidor que está envolvido na equação do produto jornalístico. Sendo assim, pedimos ao leitor que tome como sinônimos, neste caso, os termos usuário, sujeito, consumidor, interagente, agente humano, e leitor, além disso, também pedimos que tenha em mente que o tratamos enquanto um receptor plenamente ativo na relação e dotado de ações e consciência com relação ao processo, nunca como um "receptor passivo".
} 
comportamento demandam adaptação e reconfiguração de seus produtos, tanto na forma como são levados e apresentados ao público, quanto nos seus processos de construção, o que faz com que as marcas jornalísticas criem aplicativos para distribuição de seu conteúdo em dispositivos móveis digitais. Teoricamente, há a noção sistêmica da narrativa em seu momento de constituição dentro das bases de dados e códigos de programação, e também no ato da configuração na interface digital conforme o dispositivo utilizado, aqui interessando, em específico, os dispositivos ubíquos. Além disso, também faz parte de nosso objeto teórico a visualização, caracterização e consideração desses dispositivos enquanto actantes no processo de consumo de conteúdo jornalístico, levando em conta a importância da materialidade da comunicação. Também propomos a adoção do conceito de espaço híbrido para definir o lugar onde se dão as interações com o conteúdo digital, promovendo uma distinção do conceito de ciberespaço e abrindo caminho para a apresentação e aprofundamento do conceito de jornalismo ubíquo (SALAVERRÍA, 2016a), também enquanto pilar fundamental deste trabalho e dos elementos característicos deste novo formato que iremos detalhar no item 3.5 .

A fim de que possamos apresentar e investigar as características desse formato da narrativa sistêmica no jornalismo ubíquo, propomos a análise de quatro marcas jornalísticas e seus produtos para smartphones. Optamos por observar um conjunto formado por marcas tradicionais e importantes no mercado jornalístico, além de serem também alguns dos publishers com mais esforços destinados às áreas de inovação digital nas empresas. Nossa amostra é composta pelos jornais The New York Times, The Guardian, El País e O Estado de S. Paulo (Estadão). Acreditamos que com ela é possível ter um panorama do que está sendo feito pelas maiores marcas jornalísticas de diferentes regiões numa perspectiva internacional enquanto produto para dispositivos ubíquos. Como métodos, optamos por observação não participante e análise dos produtos, a partir de uma visão oferecida pela teoria dos sistemas, mais detalhada no Capítulo 2, e também entrevistas semiestruturadas in loco com editores responsáveis pelos produtos digitais das empresas. 


\subsection{Problema e justificativa}

A produção de narrativas para as mídias digitais ubíquas, na atualidade, move-se entre veículos que se utilizam da total transposição do produto impresso para o ubíquo, aqueles que se esforçam para adaptar a apresentação do conteúdo em diferentes telas e aqueles que efetivamente produzem conteúdo exclusivo para esse tipo de dispositivo. Ainda é possível ver uma dificuldade de parte do mercado em lidar com as potencialidades oferecidas pelos dispositivos ubíquos. O que também se reflete na dificuldade em apresentar um modelo de negócio lucrativo para o meio. Ao seguir transpondo conteúdo do impresso para o móvel, a indústria não compreende as necessidades e desejos de um público imerso num contexto de evolução tecnológica, além disso, não leva em consideração o comportamento do usuário com o dispositivo. $\mathrm{O}$ aprofundamento dos estudos na área pode auxiliar numa proposta de mudança desse cenário.

Para Yelvington (2004), os veículos gastam mais tempo na perseguição da tecnologia a partir de uma necessidade de estar "em dia" com as novidades, do que na análise e observação do produto que está sendo entregue ao leitor. Para o autor, os jornais replicam vícios tanto na produção de conteúdo, quanto na adoção de um modelo de negócios que não funciona na rede digital. Dois dos principais aspectos da cultura da convergência indicam que esse conceito designa a circulação de conteúdos midiáticos por múltiplos dispositivos e também o comportamento migratório dos sujeitos que buscam experiências midiáticas de consumo diferenciadas (JENKINS, 2006). Para Piccato (2015), o principal problema da indústria jornalística não é nem a internet, nem o desenvolvimento tecnológico, mas a falta de ideias para desenvolver produtos que sejam indispensáveis aos usuários dentro das novas condições impostas pelo atual ecossistema midiático, além de falta de velocidade para chegar a tempo ao mercado e cultura organizacional inovadora.

Diante disso, apresentamos como problemática desta pesquisa a seguinte pergunta: Quais são as características específicas do jornalismo ubíquo e do seu formato e como elas são ou não adotadas pelos aplicativos jornalísticos para smartphones dos jornais The New York Times, The Guardian, El País e O Estado de

S. Paulo? Ao responder essa indagação esperamos contribuir para a construção de um 
repertório de características do jornalismo ubíquo e também para a análise dos níveis de adaptação dos aplicativos de empresas a estas especificidades.

\subsection{Objetivos}

Como objetivo central de nossa pesquisa temos a intenção de responder a nossa pergunta problema, ou seja, entender e elencar quais são as características específicas do jornalismo ubíquo em smartphones e investigar a apresentação desses elementos em aplicativos jornalísticos de marcas consagradas no mercado. A fim de estabelecer etapas para a construção desta pesquisa, apresentamos um conjunto de objetivos específicos que norteiam o caminho de elaboração do trabalho e coleta de dados da investigação. São eles:

a) construir o marco teórico e metodológico que sustenta a investigação a partir das propostas da materialidade da comunicação, Teoria Ator-Rede, Teoria dos Sistemas e a metáfora das espumas;

b) expor o percurso evolutivo do conceito de jornalismo ubíquo e justificar sua presença no trabalho;

c) investigar as características que fazem parte do formato da narrativa sistêmica dentro desse jornalismo ubíquo;

d) analisar os aplicativos dos jornais selecionados na amostra de pesquisa;

e) entrevistar os profissionais das empresas selecionadas, a fim de conhecer um breve panorama das variáveis de entorno do aplicativo enquanto produto da marca jornalística;

f) apresentar uma análise da implementação das características do jornalismo ubíquo entre os produtos investigados.

\subsection{Hipóteses}

As hipóteses do trabalho percorrem o caminho que vai do empírico ao teórico, ou seja, elas têm sua origem no problema, passam pela ruptura epistemológica, constituemse na problemática teórica e tornam-se, finalmente, hipóteses teóricas de pesquisa. 
Assim, elas acabam norteando a realização da pesquisa e configurando-se em hipóteses de trabalho, a fim de que ao final da investigação se possa confirmar ou rejeitar as afirmações construídas no início no processo (LOPES, 2001).

Toda a pesquisa parte de um pressuposto, o qual abarca uma construção gradativa do estudo, isto é, parte-se de uma (ou várias) premissa(s) que direciona a elaboração dos objetivos teórico-metodológicos. Com relação a este trabalho, temos como hipóteses de pesquisa:

H1: Estamos numa era na qual o jornalismo se encontra profundamente afetado pela mobilidade digital e pela ubiquidade dos dispositivos de acesso e consumo de conteúdo, o que nos leva a uma proposta conceitual que abarca esses elementos, o jornalismo ubíquo.

H2: Esse conceito aliado ao de narrativa sistêmica carrega consigo a noção de que o formato desse jornalismo ubíquo possui uma série de novas características aliadas às camadas que compõem a narrativa e ao dispositivo de consumo.

H3: Os produtos jornalísticos atuais diferem em níveis de apresentação dessas características, resultando num mercado composto por diferentes soluções de implementação, umas mais bem adaptadas ao momento, outras menos.

Pela utilização do termo formato, se quer designar a questão da apresentação e construção do conteúdo e a interação proposta com o sujeito no ato de leitura. Ou seja, há uma tendência evolutiva da indústria jornalística e dos comportamentos de consumo do público que exigem um formato narrativo que oferece flexibilidade às especificidades do atual contexto comunicacional. Burgos (2013) chama a atenção para o fato de que a transformação no jornalismo na esfera do consumo e circulação também cria uma demanda por mudanças na estrutura produtiva das empresas, incluindo jornalistas, designers, programadores, editores, publicitários, entre outros. Sendo assim, mesmo não fazendo parte do objetivo principal desta pesquisa, abrimos o olhar do trabalho para os aspectos do entorno que envolvem a atuação dos profissionais e das marcas jornalísticas com presença digital, a fim de contribuir com um breve panorama desta questão. 


\subsection{Esquema gráfico da tese}

A fim de clarificar ainda mais o exposto até aqui e facilitar a compreensão do trajeto lógico e conceitual da pesquisa, trazemos um esquema gráfico (figura 1) que sintetiza os principais aspectos do trabalho, que se encontra na página a seguir. 
Figura 1 - Esquema gráfico da pesquisa doutoral

\section{ESQUEMA GRÁFICO DA TESE}

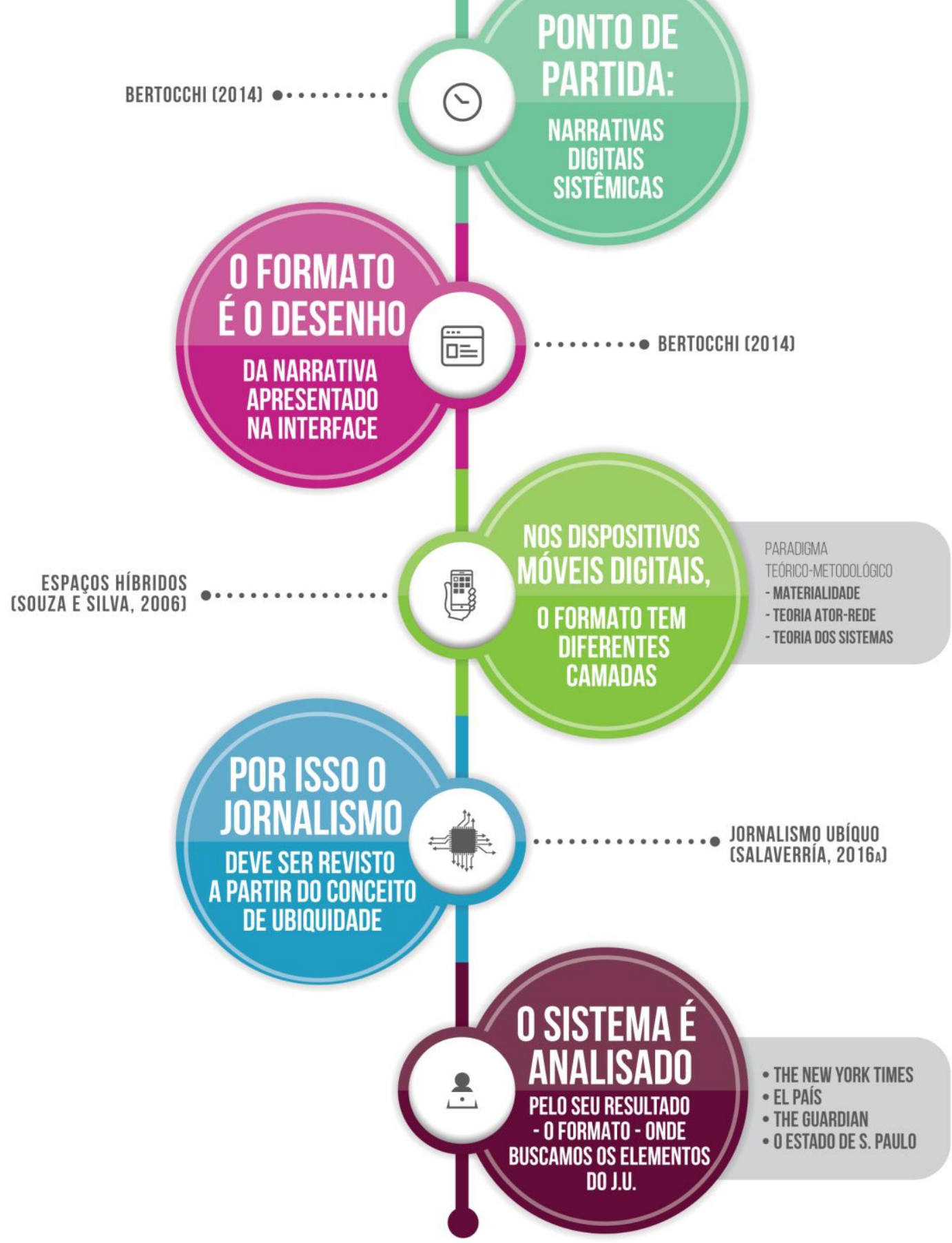

Fonte: Esta autora 


\section{MARCO TEÓRICO-METODOLÓGICO}

O objetivo deste capítulo é apresentar o marco teórico-metodológico no qual construímos e embasamos nossa pesquisa. Podemos dizer que nossa proposta é baseada num conjunto teórico que inclui a materialidade da comunicação, a Teoria Ator-Rede ${ }^{10}$, a Teoria dos Sistemas e a metáfora da espuma, proposta na teoria filosófica de Peter Sloterdijk. A união de todos esses fundamentos nos serve não só como pilar de defesa da visão proposta neste trabalho durante a realização de sua fundamentação, mas também como base teórica que sustenta a observação de nossos objetos empíricos de pesquisa.

Unir todos esses elementos significa dizer que adotamos uma postura a partir da qual vemos os dispositivos móveis digitais enquanto agentes que também atuam como mediadores do processo comunicacional, sendo peças capazes de interferir nas características de uma experiência de consumo de informação. Essa ação leva em conta a materialidade do objeto e a sua relevância no processo como algo que ultrapassa uma mera ferramenta técnica. Além disso, a Teoria dos Sistemas e a metáfora da espuma se unem para nos oferecer uma visão integrada dos atores participantes do processo comunicacional. Ou seja, somos e fazemos parte de sistemas ou esferas que interagem entre si, estão conectados e são interdependentes, o que nos permite olhar para os resultados desses sistemas a fim de compreendê-los. A espuma é ao mesmo tempo uma só e múltiplas, na medida em que é composta por outras e inúmeras espumas e esferas. Assim também são os sistemas, compostos por múltiplos sistemas menores que interagem e criam o resultado dessas interações.

Mais especificamente dentro do nosso escopo de pesquisa, este trabalho parte do pressuposto que os dispositivos móveis digitais para o jornalismo não devem ser considerados apenas aparatos técnicos que são incorporados para atender a demanda comercial. São agentes não humanos que medeiam a interação entre jornalista, produto e público. "Em vez de simplesmente prover um meio para um fim, a técnica é muito mais um modo de revelar" (SANTAELLA, 2010, p. 45). Nos próximos itens deste capítulo,

\footnotetext{
${ }^{10}$ Utilizamos aqui a denominação Teoria Ator-Rede para a proposta teórica apresentada por Latour e outros teóricos, no entanto, esclarecemos que o termo não possui unanimidade no mundo acadêmico. Segundo Holanda (2014), outros termos também utilizados para referir-se ao debate proposto pela TAR é Sociologia da Tradução, Sociologia do Social ou Sociologia das Associações. Neste trabalho, optamos pelo termo Teoria Ator-Rede para nos referir às discussões propostas por todas essas terminologias.
} 
buscamos apresentar melhor esta proposta e conectá-la à nossa base teóricometodológica.

\subsection{Materialidade e teoria ator-rede}

Como dito por Hanke (2006), pensar sobre a materialidade é entender o que pode ser feito com uma caneta sem interpretar as palavras que são escritas com ela. Neste trabalho, procuramos trazer a contribuição dos teóricos que chamam a atenção para a materialidade dos objetos, na medida em que nossa pesquisa busca exatamente isso: levar em consideração a materialidade e natureza dos dispositivos móveis digitais ao observar e analisar os produtos jornalísticos que neles são oferecidos.

Para Felinto (2006), as tecnologias da comunicação não estão limitadas a propagar ideias, mas interferem em como os espaços e territórios sociais são estruturados. Para o autor, os artefatos da comunicação são mais do que instrumentos transmissores de mensagens, eles transmitem cultura, estruturam relações sociais e ambientes humanos. Felinto também defende que quando se fala sobre a materialidade da comunicação é preciso ter clara a ideia de que todo o ato comunicacional demanda a presença de um suporte material para se efetivar, e isso influencia a natureza e a estrutura da mensagem.

Em primeira instância, falar em "materialidades da comunicação" significa ter em mente que todo ato de comunicação exige a presença de um suporte material para efetivar-se. Que os atos comunicacionais envolvam necessariamente a intervenção de materialidades, significantes ou meios pode parecer-nos uma ideia já tão assentada e natural que indigna de menção. Mas é precisamente essa naturalidade que acaba por ocultar diversos aspectos e consequências importantes das materialidades na comunicação - tais como a ideia de que a materialidade do meio de transmissão influencia e até certo ponto determina a estruturação da mensagem comunicacional (FELINTO, 2001, p. 3).

Gumbrecht (2010), um dos principais articuladores da teoria das materialidades da comunicação, ao definir a pós-modernidade, descreve o sentimento de um mundo "não mais fundado na figura central do sujeito" (p. 391). No campo da hermenêutica, segundo ele, a materialidade da comunicação é um elemento secundário, de menor importância em relação à dimensão do sentido dado pelo sujeito no processo comunicacional, focando assim na interpretação mais do que na expressão. Já no campo 
não hermenêutico importam as formas da expressão, ou ainda, as formas materiais da expressão, a materialidade dos significantes. "[...] não mais procuramos identificar o sentido, para logo resgatá-lo, porém, indagamos as condições de possibilidade de emergência das estruturas de sentido" (GUMBRECHT, 2010, p. 399).

A partir dessas constatações, Gumbrecht propõe a valorização da materialidade de todo processo. Ou seja, trazemos o autor aqui para, mais uma vez, enfatizar nossa argumentação de que a materialidade dos dispositivos é parte fundamental a ser levada em conta na análise de um cenário comunicacional específico. Um smartphone possui uma materialidade específica capaz de influenciar o tipo de acoplagem que este, enquanto sistema, realizará com outros sistemas externos e até mesmo internos a ele. Além disso, essa materialidade é dotada de affordances ${ }^{11}$ específicas que engendram nos sistemas usuários/sujeitos comportamentos diferentes daqueles que seriam mobilizados em acoplagens com outros sistemas em diferentes estados. "[...] a materialidade e o sentido desenvolvido a partir dela são considerados inseparáveis" (HANKE, 2006, p. 221).

Para Felinto (2001), falar em materialidade da comunicação não significa sugerir uma epistemologia completamente nova ao campo da comunicação, mas sim partir de um novo ponto de vista dentro da noção já tradicional. $\mathrm{O}$ autor esclarece que a tradição filosófica parte de uma ideia onde o significado precede o significante, ou ainda, onde o espiritual, a interpretação, são mais valorizados do que o corporal, a expressão. No entanto, apoiando-se em Derrida, afirma que "o significante é anterior ao significado", ontologicamente falando. "Isso significa que as tecnologias de inscrição, de comunicação, não são meros instrumentos com os quais os sujeitos produzem sentido. Elas antes representam o horizonte a partir do qual algo como o próprio sentido em geral pode surgir" (FELINTO, 2001, p. 10).

Anderson e Maeyer (2015), ao defenderem seu posicionamento de pesquisa com foco nos "objetos do jornalismo", argumentam que esse direcionamento não os desvia do contexto social no qual a tecnologia se desenvolve, mas sim, oferece uma nova janela para o social, o material e o contexto cultural no qual o cotidiano se torna cada vez mais tecnológico. Segundo os autores, esse tipo de posicionamento é capaz de trazer um entendimento relacional e não determinista da tecnologia, enxergando a materialidade

\footnotetext{
${ }^{11}$ Affordance, segundo Gibson (1986), é aquilo que o ambiente/objeto possibilita a quem interage com ele. O conceito é mais bem aprofundado no capítulo 4 deste trabalho.
} 
dos objetos como inevitavelmente imbricada numa rede de relações humanas e não humanas.

De acordo com os autores, os estudos que conectam o tema da materialidade ao jornalismo traçam, comumente, uma ligação com a Teoria Ator-Rede e o trabalho de Bruno Latour, ou seja, estudam humanos e não humanos, ou ainda, partem do princípio que o que é social não está desconectado do que é material. Em sua maioria, os estudos que partem dessas abordagens possuem como temas, segundo eles, a inovação tecnológica e as mudanças provocadas por essa, incluindo novas ferramentas inseridas no trabalho jornalístico.

Latour (2012) sugere que a materialidade não é apenas um intermediário técnico no processo comunicacional, mas um ator não humano que transforma e opera internamente o conjunto. Tanto de Latour quanto de Gumbrecht têm-se propostas para uma revisão do conceito de social sugerido pelo pensamento humanista, para que assim possamos observar outros elementos no processo comunicacional e não apenas o sujeito humano como questão chave. Felice (2013) também explica que a sociologia tradicional se fundamentou na superioridade do homem sobre a natureza e as coisas, considerando social somente aquilo que se dava entre humanos. "[...] as ciências sociais construíram suas teorias sobre o social a partir do pressuposto epistêmico da independência e da supremacia do humano sobre a técnica e a natureza" (p. 14). No entanto, a teoria atorrede amplia esse espectro para que enxergue também as interações com não humanos, natureza e técnica.

Latour traz à tona a questão da agência dos objetos. Segundo ele, a visão da sociologia tradicional considerava a ação um comportamento humano, pois era constituído de intenção ou significado. A própria definição de ator e ação dentro da sociologia tradicional, segundo Latour (2012), impede que se pense em objetos "agindo". Para ele, no entanto, "qualquer coisa que modifique uma situação fazendo diferença é um ator" (p. 108, grifo do autor).

Na mesma linha de pensamento, o geógrafo Milton Santos (2006) esclarece que há uma inseparabilidade entre o objeto, seu contexto, a interação entre os sistemas atuantes e o sistema de objetos contido num espaço em transformação. Para o pesquisador, não é possível pensar numa realidade filosófica para os objetos porque não se está habilitado a conhecê-los de fora do sistema em que atuam, o qual também não existe separadamente do próprio objeto em si. Para Latour (2012), o ponto importante é 
definir o agente com base naquilo que ele faz, por isso, o uso da palavra actante, a fim de que se inclua tanto humanos quanto não humanos no processo. A Teoria Ator-Rede proposta por ele entende que a definição de social estática e imóvel não dá conta das instabilidades e controvérsias que podem ocorrer durante a associação dos agentes.

Para a $\mathrm{ANT}^{12}$, como agora já sabemos, a definição do termo é outra: não designa um domínio da realidade ou um item especial; é antes o nome de um movimento, um deslocamento, uma transformação, uma translação, um registro. É uma associação entre entidades de modo algum reconhecíveis como sociais no sentido corriqueiro, exceto durante o curto instante em que se confundem. [...] Assim, para a ANT; social é o nome de um tipo de associação momentânea caracterizada pelo modo como se aglutina assumindo novas formas (LATOUR, 2012, p. 99 e 100, grifo do autor).

Nesse sentido, o caminho das associações é criado pelos próprios actantes, pelo andamento das possíveis instabilidades. Para o autor, a ordem é trazida pelo desdobramento dos processos e não podemos impor um sentido dado e posto às ações, mas sim acompanhá-las, entendendo que os humanos criam e agem com os artefatos não humanos, mas esses também reagem sobre eles e interferem nas formas de associação finais. O homem cria o artefato, mas esse também o recria quando ambos entram em interação.

\begin{abstract}
Você é diferente com uma arma na mão; a arma é diferente com você segurando-a. Você é outro sujeito porque está segurando uma arma; a arma é um outro objeto porque entrou em uma relação com você. A arma não é mais a arma no arsenal ou a arma na gaveta ou a arma no bolso, mas sim a arma na sua mão, apontada para alguém que está gritando. O que é verdade sobre o sujeito, sobre o atirador, é também tão verdade sobre o objeto, a arma que é apontada. [...] O duplo erro dos materialistas e dos sociólogos é começar com essências, dos sujeitos e dos objetos. Esse ponto de partida torna impossível a mensuração do papel de mediação da técnica. Nem sujeito, nem objeto (nem suas intenções) são fixos (LATOUR, 1994b, p. 33) ${ }^{13}$.
\end{abstract}

Mais do que discutir a questão do social em Latour e nos outros autores que convergem com ele, nos interessa neste trabalho enfatizar o aspecto da agência dos

\footnotetext{
${ }^{12}$ ANT é a sigla utilizada para Teoria Ator-Rede em inglês, Actor-Network Theory.

${ }^{13}$ Tradução da autora, trecho original: "You are different with a gun in hand; the gun is different with you holding it. You are another subject because you hold the gun; the gun is another object because it has entered into a relationship with you. The gun is no longer the gun-in-the-armory or the gun-in-thedrawer or the gun-in-the-pocket, but the gun-in-your-hand, aimed at someone who is screaming. What is true of the subject, of the gunman, is as true of the object, of the gun that is held. [...] The twin mistake of the materialists and the sociologists is to start with essences, those of subjects or those of objects. That starting point renders impossible our measurement of the mediating role of techniques. Neither subject nor object (nor their goals) is fixed."
} 
objetos $^{14}$. Essa agência, obviamente, não é sinônimo de que o objeto determina a ação, mas sim que ele é parte fundamental dela, assim como também o são os outros atores que dela participam. Este trabalho seria completamente diferente caso estivesse sendo escrito à mão ou numa máquina de escrever, ou ainda, se estivesse sendo escrito num computador sem acesso à internet. Esses objetos não determinam a realização ou não do trabalho, mas influenciam, "autorizam, permitem, concedem, estimulam, ensejam, sugerem, influenciam, interrompem, possibilitam ou proíbem", usando os verbos trazidos por Latour.

\begin{abstract}
A ANT não alega, sem base, que os objetos fazem coisas "no lugar" dos atores humanos: diz apenas que nenhuma ciência do social pode existir se a questão de o quê e quem participa da ação não for logo de início plenamente explorada, embora isso signifique descartar elementos que, à falta de termo melhor, chamaríamos de não humanos. [...] Para os sociólogos de associações, o que é novo não é a multiplicidade de objetos mobilizados por um curso de ação ao longo do caminho - ninguém jamais negou que eles existam aos milhares. Novo é o fato de os objetos surgirem de súbito não apenas como atores completos, mas também como aquilo que explica a paisagem variegada pela qual começamos, os poderes supremos da sociedade, as notórias assimetrias, o rude exercício do poder (LATOUR, 2012, p. 109, grifo do autor).
\end{abstract}

Essa citação de Latour é essencial para compreendermos o local de onde estamos falando neste trabalho, ou, a proposta teórico-metodológica que adotamos como base para conduzir esta pesquisa. Como poderíamos explicar o cenário midiático atual se não déssemos a devida atenção ao agenciamento dos dispositivos móveis digitais? Como seria possível compreender o contexto da comunicação na era atual sem levarmos em conta, enquanto atores, os aparatos tecnológicos, a internet, os smartphones e a conexão ubíqua? Parece-nos claro que, principalmente para o nosso objeto de pesquisa (mas não somente para ele) é fundamental a compreensão da importância da agência dos objetos. “Como, em uma área como a da comunicação, na qual tudo é mediado por artefatos tecnológicos sofisticados, não dar atenção aos híbridos? Essa é a Teoria Ator-Rede (TAR)" (LEMOS, 2013, p. 23).

\footnotetext{
${ }^{14}$ É importante esclarecer aqui que a Teoria Ator-Rede funciona, nesta pesquisa, como um pilar teóricometodológico, mas não como um procedimento metodológico. Ou seja, o procedimento ligado à TAR, a cartografia das controvérsias, não faz parte do método que adotamos para observação e análise do nosso objeto empírico de pesquisa. O que tomamos da teoria é o olhar abrangente sobre os atores não humanos dentro do processo comunicacional, logo, isso quer dizer que a teoria está presente nesta pesquisa para auxiliar na explicação e construção de nossa "lente" de observação do objeto, nossa visão da sociologia como algo distante de um determinismo humano ou técnico.
} 
Para produzir conteúdo jornalístico são necessários diversos elementos: jornalistas, papel, tablet, redes, internet, computadores, telefones, publicitários, anunciantes, distribuidores, escolas de comunicação, satélites, concorrentes etc. Conforme Lemos (2011), a ação do jornalismo é fruto de um conjunto de associações entre actantes humanos e não humanos, logo, não é possível dissociar da produção de conteúdo a importância do dispositivo móvel digital e sua especificidade técnica. Para que a acoplagem jornalismo-artefato móvel-leitor se constitua efetivamente é preciso que todos os elementos envolvidos sejam considerados, pois todos estão numa relação de codependência e conexão. Trata-se de uma associação entre agentes múltiplos.

Lemos (2011) propõe que os agentes não humanos sejam vistos de uma forma diferente daquela que o pensamento tradicional atribui a eles: o comportamento de entidades passivas. Para o autor, um computador, leis, um telefone, um martelo, redes sociais online, não são de um lado intermediários e de outro, atores, mas sim podem exercer ambos os papéis de acordo com as associações que forem criadas durante seu uso. Actante remete a tudo aquilo que gera ação, logo, se há ação pode-se utilizar o termo para designar o objeto, do contrário não há actante. Os agentes não humanos entram em ação quando acoplados a outros agentes, logo, o tornar-se actante constituise em conjunto e num processo de interação. Lemos explica que, para Latour, o social é o resultado das associações e não a explicação delas. Ferramentas só são apenas ferramentas quando não estão produzindo ação.

\footnotetext{
Retire do "jornalismo" a internet, as empresas jornalísticas, as universidades e professores de jornalismo, os jornaleiros, os distribuidores, os computadores, os celulares, os órgãos reguladores, o papel jornal, a web... e veja se você ainda vê algum "sujeito" livre de amarras! [...] A genialidade e originalidade de uma ação não vêm da independência de outros actantes, mas justamente do contrário: das boas associações estabelecidas (LEMOS, 2011, p. 18 e 19).
}

Essa noção de que os objetos (e também os humanos) só são atores quando mobilizados ou quando seus traços podem ser detectados nos leva à ideia de mediação em Latour. Para o autor, um objeto pode ser mediador ou intermediário, sendo o primeiro aquele que transforma, altera, mexe com a ação na qual estão envolvidos e, o segundo, é aquele que não interfere no processo, apenas atua como um suporte. O mediador é complexo, múltiplo; o intermediário é uma coisa só, único. 
uma caixa-preta, mas uma caixa-preta que funciona como uma unidade, embora internamente seja feita de várias partes. Os mediadores, por seu turno, não podem ser contados como apenas um, eles podem valer por um, por nenhuma, por várias ou uma infinidade. O que entra neles nunca define exatamente o que sai; sua especificidade precisa ser levada em conta todas as vezes. Os mediadores transformam, traduzem, distorcem e modificam o significado ou os elementos que supostamente veiculam (LATOUR, 2012, p. 65 , grifos do autor).

Aqui, mais uma vez, a definição proposta por Latour nos traz um elemento crucial para a pesquisa que desenvolvemos. Os dispositivos móveis digitais podem ser mediadores e não somente intermediários e, por isso, a relevância da defesa teóricometodológica apresentada. Ao consumirmos conteúdos via smartphones ou tablets, nossa percepção é naturalmente diferenciada do que aquela que teríamos caso consumíssemos esse mesmo conteúdo pelo computador pessoal ou pelo jornal impresso. A materialidade do artefato importa e exerce um papel, é um ator, transformando e modificando o resultado apresentado na interface do aparelho. "Humanos comunicam. E as coisas também. E nos comunicamos com as coisas e elas nos fazem fazer coisas, queiramos ou não. E fazemos as coisas fazerem coisas para nós e para outras coisas. É assim desde o surgimento do humano no planeta" (LEMOS, 2013, p. 19).

Santaella e Cardoso (2015) reforçam que a mediação deve ser compreendida como o resultado de uma associação, da influência homem-objeto, objeto-homem. Segundo os autores, no contexto da tecnologia digital esse aspecto fica ainda mais evidente, pois os sensores que carregamos conosco diariamente são capazes de nos alertar de algo, validar uma ação específica ou ainda impedir algo de ser executado. "A ideia de ação funda não apenas a condição técnica, como também a condição humana" (p. 175).

Isso não quer dizer, obviamente, que um ator não humano nunca possa ser um intermediário ou que em nenhum momento um dispositivo móvel digital possa ser comportar como intermediário. No olhar que recortamos para esta pesquisa, dentro de uma ação de consumo de conteúdo jornalístico via dispositivo móvel digital, consideramos que o artefato exerce uma função de mediador, no entanto, justamente por termos um olhar fundado na TAR, não podemos marcar essa função como definitiva e imutável. Tudo depende da associação, da rede que se forma entre atores, sejam eles humanos e não humanos. Da mesma forma, sem hierarquia, um humano também poderia exercer a função de intermediário. Como afirma Lemos (2013), o intermediário o é ou se constitui como um, num contexto de subsistência e não de substância. 
Westlund e Lewis (2014) defendem que, na atualidade, é necessário conceituar melhor as mudanças na natureza dos atores humanos e não humanos também dentro do jornalismo. Para os autores, as transformações tecnológicas dos últimos anos fizeram com que a fronteira entre produção e consumo ficasse obscura, trazendo novas configurações aos atores humanos e não humanos, às audiências e às rotinas de produção da atividade jornalística. No entanto, para eles, os estudos sobre jornalismo têm uma tendência a ser humano-centrados, investigando os papéis profissionais ou as restrições editoriais nas organizações, sem reconhecer suficientemente a relevância da tecnologia nas interações.

Para tentar suprir essa lacuna, os autores propõem o desenvolvimento de uma ênfase sociotécnica nos estudos sobre jornalismo. A proposta não é nem determinista sobre a influência da tecnologia, nem determinista sobre o papel dos sujeitos, a ideia é oferecer um olhar que possa revelar nuances nas relações entre todos os atores que continuamente formam redes que envolvem o jornalismo. Westlund e Lewis (2014) apresentam uma fundamentação para a pesquisa em jornalismo que envolva a produção em multiplataformas. Para isso, eles definem 4A's que fazem parte dessa proposta: atores, actantes, audiências e atividades.

Em atores, os pesquisadores propõem que se enxergue dentro e também além da organização jornalística, desde fontes, a anunciantes, fornecedores, programadores, designers, vendedores e equipe administrativa. Em actantes, os autores localizam todos os elementos materiais essenciais para o desenvolvimento da atividade jornalística, incluindo os computadores e impressoras da redação, até o sistema de publicação de conteúdo e os algoritmos nele programados. Em audiência, estão todos os sujeitos que podem vir a consumir o conteúdo jornalístico produzido e distribuído e, por último, em atividades, estão todos os tipos de rotinas e práticas da empresa jornalística - editoriais ou não - que revelam como resultado o produto enviado aos consumidores. O objetivo dessa divisão no trabalho apresentado por eles é colocar os quatro elementos num quadro de estágios da produção jornalística e demonstrar que, em muitos momentos, todos os elementos participam, interferem e modificam as etapas de produção do conteúdo jornalístico, de forma semelhante, sem a predominância do sujeito jornalista, que ocorria comumente nos estudos tradicionais sobre jornalismo.

Nosso foco aqui se dá em apenas uma esfera desses elementos por questões de recorte de pesquisa, dado o tempo e os recursos disponíveis. No entanto, estamos cientes 
do volume de atores híbridos envolvidos no sistema jornalismo e no quanto es ses estão imbricados na rede de interação, influenciando-se mutuamente e sendo corresponsáveis pelos rastros que podemos acompanhar desses atos de mediação e comunicação. Ainda assim, não adotamos a proposta dos autores, embora reconheçamos sua importância, pois não é objetivo deste trabalho atuar dentro dos limites e recortes sugeridos por eles.

\subsection{Sistemas, espumas e objetos}

Como afirma Bertocchi (2014), a teoria dos sistemas oferece uma perspectiva que ajuda a observar e compreender fenômenos complexos da atualidade. Em sua pesquisa, a teoria serve como base para pensar a narrativa digital de forma holística, nesse caso, a narrativa se apresenta como o resultado visível do sistema, sendo assim possível enxergar, a partir dela, o sistema complexo do qual faz parte. Na sua visão, a narrativa é um sistema:

[...] no qual atuam distintos atores humanos e não humanos e que produz um todo maior que suas partes. A narrativa digital jornalística passa a ser, portanto, necessariamente, um ato coletivo. Como sistema complexo, agrega subsistemas com regras singulares (BERTOCCHI, 2014, p. 14).

$\mathrm{Na}$ teoria dos sistemas, cada parte do todo exerce uma função essencial que individualiza esse elemento. A sua função, de acordo com Lima (2014), condiciona o comportamento do sistema como um todo e também de seus subsistemas. A empresa jornalística pode ser considerada um sistema que abarca e depende de diversos outros sistemas internos e externos, todos com funções associadas entre si, aí se incluem jornalistas, redação, jornaleiros, computadores, consumidores, dispositivos de consumo, entre outros, todos operando de forma interligada e interdependente.

\footnotetext{
Para reagir satisfatoriamente aos estímulos do ambiente, há necessidade de funcionamento orientado contextualmente. De nada adianta a redação da Gazeta produzir um ótimo trabalho de cobertura sistêmica da realidade, se o departamento comercial patina pela falta de sintonia com a proposta editorial, buscando suporte publicitário onde não há afinidade temática com a linha do veículo (LIMA, 2014, p. 453).
}

Da mesma forma, como dito acima pelo autor, que defende a necessidade de um sistema funcionar orientado contextualmente, o sistema de uma empresa jornalística deveria operar levando em consideração o seu entorno e, consequentemente, os outros 
sistemas que entram em interação. Na questão específica dos dispositivos móveis digitais, o que queremos apresentar nesta pesquisa é a necessidade de que os agentes levem em conta a importância dos outros e as suas características específicas. Quando a instituição jornalismo leva em consideração a relevância do papel exercido pelo actante não humano, ela pode ser capaz de produzir de forma a aproveitar todas as potencialidades oferecidas pelo dispositivo, funcionando a seu favor na constituição dessa associação entre agentes.

Assim como a TAR, a teoria dos sistemas busca romper com a ideia de causa e efeito para explicar um fenômeno, voltando-se para as relações, interações e influências que ocorrem dentro da própria rede constituída pelos atores. Segundo Lima (2014), um sistema é composto por subsistemas que, por sua vez, são constituídos de outras partes e todos estão integrados, havendo dinâmicas de trocas entre eles e o ambiente externo.

A comunicação, processo que dá liga essencial a essas interações notavelmente
desafiadoras, é majoritariamente ainda encarada sob parâmetros concebidos no
mundo menos complexo do século XIX e primeira metade do século XX.
Convém um salto de qualidade na assimilação do universo sistêmico (LIMA,
2014, p. 449).

Ao citar a teoria dos sistemas, Gumbrecht (2010) explica que, nela, os sistemas só são capazes de "perceber" o mundo exterior a partir da autorreferência, ou seja, produz-se uma referência interna e pressupõe-se uma realidade externa, no entanto, sem conhecê-la. Assim, o Eu-sistema só existe a partir da diferenciação do Outro-sistema. Ainda dentro da observação da teoria sistêmica, Gumbrecht traz o conceito de acoplagem de Maturana e Varela. A ideia de acoplagem pressupõe a existência de dois sistemas e sua ocorrência pode se dar em primeiro ou segundo nível. No primeiro nível, um sistema condiciona o estado do outro e vice-versa, mas de forma finita, sempre dentro de uma sequência de possibilidades. Um exemplo dado pelo autor é o samba. $\mathrm{O}$ ritmo é um exemplo de acoplagem finita.

Aqui, interessa-nos, mais especificamente, o segundo nível. Nele, a acoplagem dos sistemas é capaz de engendrar diferentes estados de forma infinita. Ou seja, neste caso, a acoplagem possui um caráter produtor, gerando estados novos e desconhecidos. Nesse aspecto, temos um dos elementos a serem considerados em nosso método de trabalho nesta pesquisa. Ao observarmos, utilizarmos e analisarmos um aplicativo jornalístico para smartphones geramos um estado específico dessa acoplagem, no entanto, esse estado só o é por ser parte dessa acoplagem e, nesse sentido, somos, ao 
mesmo tempo, independentes pois também somos capazes de observar essa acoplagem de um exterior. Para um observador, um sistema é sistema somente se por meio de suas próprias operações o sistema se volta a si mesmo como sistema.

De fato, faz parte da acoplagem, no entanto, pretende observá-la como se não o fizesse. E, uma vez que a acoplagem de segundo nível engendra a ilusão, impressão de realidade, isto é, quando emerge o estado de auto-observação, então já se dispõe de um nível de observação ou de representação: um nível semântico. [...] Ao descrever a acoplagem do corpo de Nietzsche com sua máquina de escrever, devo considerar que a forma material desta máquina desempenha um papel decisivo na constituição do sentido. A máquina, enquanto forma, contribui à acoplagem. Portanto, acrescentaríamos a possibilidade de incluir o aspecto da materialidade dos meios (GUMBRECHT, 2010, p. 402).

Em consonância com Latour e Gumbrecht, Luhmann (1996) afirma que a sociologia não pode tentar ver o mundo sem se colocar dentro dele, como parte do objeto que a pesquisa irá se ocupar. Para Luhmann, a comunicação deve ser o ponto de partida de uma reflexão sobre o social já que, ao ser a estrutura basal mais abarcadora, inclui a ação, sem esgotar-se nela. O autor explica a constituição dos sistemas a partir da diferença com o entorno, sendo assim, a comunicação em seu sentido mais abstrato e geral é uma observação enquanto efetua uma diferença. Portanto, o nível de abstração mais alto em que se pode colocar a comunicação é a operação de observação. Ao observar, utilizamos a diferença para designar um algo e um outro. "A operação de observação é capaz de efetuar - como consequência de sua dinâmica paradoxal - a observação sobre si mesma, de tal maneira que pode levar a cabo uma observação da observação: uma observação de segunda ordem" (p. 17) ${ }^{15}$.

A teoria dos sistemas abre espaços de comparação a partir da observação exercida de forma consciente de sua integração ao sistema. Apesar disso, ela nunca espera o esgotamento de todas as análises e hipóteses a partir dos resultados visíveis do sistema, pois esses se transformam ao longo do tempo e das próprias interações (LUHMANN, $1998)^{16}$.

Justamente aqui começa o trabalho da dita teoria. Ela situa a relação com seu objeto de investigação como uma relação entre complexidade não transparente

\footnotetext{
15 Tradução da autora, trecho original: "La operación de la observación es capaz de efectuar - como consecuencia de su dinámica paradójica - la observación sobre sí misma, de tal manera que puede llevar a cabo una observación de la observación: una observación de segundo orden".

${ }^{16}$ Assim também se dá a pesquisa aqui descrita. Observamos um objeto sem nos distanciar da relação complexa que se estabelece nesse processo e também sem objetivar esgotar todos os elementos possíveis de análise, mas sim contribuir para o avanço das pesquisas no campo da comunicação e também de temas relacionados ao jornalismo e sua evolução ao longo dos anos.
} 
e complexidade transparente. Nunca reclamando para si mesmo o reflexo total da realidade do objeto nem o estamento de todas as possibilidades de conhecimento do objeto (LUHMANN, 1998, p. 8) ${ }^{17}$.

Sloterdijk (2006) também critica a ontologia, assim como Luhmann, e oferece a noção de espumas para compreensão da época atual do ponto de vista de que a vida se desenvolve de maneira multifocal, multiperspectivista e heterárquica. A ideia de heterarquia é trazida por ele a fim de romper com o modelo de hierarquia de um ator sobre outro ou de um sistema sobre outro. Nela, não há poder unidirecional, mas sim um conjunto independente e interdependente de seres, operando relações bidirecionais e horizontais. A espuma é heterárquica, é uma rede antropotécnica.

Peter Sloterdijk tem uma opinião bem formada a respeito do mundo digital das espumas. Para ele, a vida se articula em cenários simultâneos, imbricados uns com outros, se produz e consome em oficinas interconectadas. Mas o que é decisivo para nós: ela produz sempre o espaço no que é e que é nela (BAIRON, 2015, p. 362).

Assim como Latour (2012), Sloterdijk (2006) também descarta a noção clássica de sociedade e até mesmo a própria palavra. As espumas apresentam a ideia de superação de uma esfera única para esferas múltiplas, poliesferas. O mundo atual, que Bauman chama de líquido, é ainda mais fluido em Sloterdijk e não parece mais adequado observá-lo a partir das ideias tradicionais da sociologia clássica. Como afirma Santaella (2007):

[...] as esferas são, ao fim e ao cabo, índices da denúncia do autor contra a ontologia e lógica tradicionais nas suas divisões dicotômicas entre corpo e alma, espírito e matéria, sujeito e objeto, liberdade e mecanismos, entre o eu e o mundo e, mais além entre a natureza e a cultura (p. 23).

Podemos perceber que todos os autores que utilizamos aqui estão em consonância, cada um a seu modo e cada um em sua proposta teórica, com a evolução dos preceitos da Sociologia tradicional e também, porque não dizer, da própria tradição de pesquisa em Comunicação. Inscrever o nosso trabalho no âmbito das discussões que envolvem os conceitos discutidos até esse momento, implica na aceitação do constante movimento de transformação nos objetos de pesquisa empíricos e, consequentemente, teóricos. Isso não quer dizer que o trabalho torna-se menos fundamentado ou sólido em

\footnotetext{
${ }^{17}$ Tradução da autora, trecho original: "Justamente aquí empieza el trabajo de dicha teoría. Sitúa la relación con su objeto de investigación como una relación entre complejidad instrasparente y complejidad transparente. Nunca reclama para sí misma el reflejo total de la realidad del objeto ni el agotamiento de todas las posibilidades de conocimiento del objeto".
} 
suas bases teóricas. Significa, sim, entender que é preciso dar conta do hibridismo do campo da comunicação, em que é necessário recorrer a diversos outros campos a fim de obter o melhor olhar epistemológico sobre o objeto, e ainda da mutabilidade dos objetos que obriga o pesquisador a estar em constante alerta acerca de teorias e suas aplicações empíricas.

Corrêa (2015) destaca esse aspecto e afirma que é preciso entender que há um enraizamento da tecnologia em quase todas as atividades comunicativas e informativas da atualidade. A autora defende que, nesse contexto, é preciso inserir posturas de resiliência nas abordagens teórico-metodológicas dos trabalhos desenvolvidos no campo da comunicação. Além disso, também é preciso compreender que a atual condição do campo irá demandar dos pesquisadores algumas reinterpretações e novos entendimentos de conceitos consolidados do campo como, por exemplo, mediação, mídia, consumidor, interação e social.

[...] o momento ora vivenciado pelo campo privilegia a abertura, a dissolução de fronteiras e a experimentação de combinações teórico-metodológicas, enfim uma disciplinaridade de protocolos de pesquisa, mas uma não disciplinaridade de paradigmas e teorias (CORRÊA, 2015, p. 12).

Essa postura apresentada pela autora está em consonância com o que se pretende no desenvolvimento deste trabalho. Buscamos, portanto, um olhar resiliente e híbrido sobre o campo da Comunicação, trazendo para a discussão o enraizamento da tecnologia na comunicação contemporânea e, com isso, uma consequente e necessária visão atualizada sobre os objetos empíricos e teóricos deste contexto. Isso implica numa necessária superação de visões baseadas em determinismos sociais, tecnológicos, lógicas causais, ou ainda demasiadamente apocalípticas ou otimistas.

Para Felinto (2001), a materialidade da comunicação não possui um objeto de estudo específico, mas sim pode ter seus princípios aplicados a diversos e inúmeros objetos. Nesse aspecto, Felinto faz uma crítica à incessante busca de muitos teóricos e pesquisadores sobre qual seria o objeto de pesquisa do campo da comunicação. Fugindo de uma ideia de epistemologia pura, isolada e intocada por outros campos do conhecimento, a materialidade é transdisciplinar e aplicável a um múltiplo número de objetos. "O que importa aqui não é essencialmente a natureza, o estatuto ontológico, do objeto, mas sim a busca de um novo modo de encarar os objetos culturais" (FELINTO, 2001, p. 11). 
Tanto Felinto, quanto Gumbrecht e também Latour e Luhmann voltam suas pesquisas para um olhar que se distancia do paradigma da Modernidade. Latour (1994) defende em "Jamais fomos modernos" um distanciamento do purismo epistemológico amparado dentro do âmbito da Modernidade. A condição de heteronomia entre campos e saberes, humanos e não humanos também é criticada por Sloterdijk (2006). Tanto Latour quanto Luhmann e Sloterdijk convergem na proposição de que o social não pode ser estudado separado ou distante do observador. O social não é uma instância que pode ser aplicada a fenômenos específicos para explicá-los sem que a ciência, o observador e o próprio fenômeno estejam inseridos no contexto. O social e o natural estão juntos no contexto, assim como objetos humanos e não humanos.

Ao utilizar essas propostas neste trabalho estamos, consequentemente, direcionando a pesquisa para um ponto distante do determinismo social que defende a superioridade do ator humano em relação à técnica dentro dos processos de comunicação. Ao dialogar com esses autores e outros teóricos apresentados no próximo capítulo que se distanciam da ideia de cisão entre virtual e real, este trabalho quer mostrar que não há superioridade em nenhum dos pontos, agentes humanos e não humanos são interdependentes e evoluem mútua e continuamente.

[...] a evolução biológica humana é inseparável da evolução tecnológica até o ponto de tornar-se impossível explicar a primeira na ausência da segunda, conforme tem sido trabalhado por autores que defendem a coevolução entre os humanos e máquinas (MAZLICH, 1994 apud SANTAELLA, 2010, p. 51) ${ }^{18}$.

Lievrouw (2014) propõe uma "abordagem de mútua modelagem” quando se trata de pesquisas envolvendo tecnologia e comunicação. Para a autora, devemos ter um olhar que veja a comunicação contemporânea como a articulação de artefatos, práticas e arranjos, pois os três elementos são mutuamente determinantes. No que diz respeito aos artefatos, Lievrouw afirma que a materialidade é o caráter físico dos artefatos que os torna úteis para determinados propósitos, quando usados em condições específicas.

Esta definição coloca em primeiro plano a materialidade dos artefatos, das coisas, não para negar a materialidade das práticas, do social ou das instituições, mas para considerar como os estudos de tecnologia da comunicação também podem engajar-se mais profundamente com a materialidade dos próprios dispositivos sem necessariamente se abrir às cobranças do determinismo tecnológico simplista. Uma abordagem mais imparcial ou congruente com a materialidade dos objetos, assim como das

\footnotetext{
${ }^{18}$ MAZLICH, Bruce. The fourth discontinuity: the co-evolution of humans and machines. New Haven:
} Yale University Press, 1994. 
práticas, arranjos sociais e instituições, pode, por exemplo, abrir caminho para reconceituações de fenômenos de comunicação essenciais, como canal, interação, mensagem, organização e comunicação em grupo ou efeitos (LIEVROUW, 2014, p. 25) ${ }^{19}$.

Nossa proposta teórico-metodológica se interconecta, na medida em que os estudos da materialidade da comunicação liderados por Gumbrecht estão ligados à teoria sistêmica de Luhmann. A Teoria Ator-Rede, por sua vez, também se interliga à materialidade da comunicação e tanto essa, quanto a teoria dos sistemas encontram ecos na proposta de espumas apresentada por Sloterdijk. Além disso, também nos alinhamos a Pires (2010) que afirma que o pensamento comunicacional da atualidade migrou da fase centrada no "determinismo futurista", onde tomavam conta a surpresa em relação às tecnologias e a polarização entre pessimistas e otimistas, para uma visão "mais madura dos fenômenos cotidianos", em que a discussão sai da especulação e volta-se para a empiria.

\subsection{Método}

Saindo da discussão teórico-metodológica e passando aos procedimentos e métodos que são adotados no trabalho, fazemos a opção pela pesquisa aplicada, que, segundo Santaella (2001), é o tipo de pesquisa que visa a um conhecimento referenciado à realidade empírica e na qual são concentrados os conhecimentos já disponíveis e aplicados a um objeto empírico. Desse processo podem resultar a resolução do problema de pesquisa, a ampliação da compreensão do problema e o surgimento de novas questões a serem investigadas.

As teorias estudadas e propostas ao longo da construção do trabalho atuam na pesquisa a fim de oferecer um quadro teórico dos fatos empíricos. A articulação dos dados e conceitos ocorre a partir de duas operações propostas por Lopes (2001): a exposição e a causação. A primeira é a apresentação do discurso científico indicado

\footnotetext{
${ }^{19}$ Tradução da autora, trecho original: "Such a definition foregrounds the materiality of artifacts, of things, not to deny the materiality of practices or social or institutional forms, but to consider how communication technology studies might also engage more fully with the materiality of the devices themselves without necessarily opening itself to charges of simples technological determinis $\mathrm{m}$. A more evenhanded or congruent approach to the materiality of objects as well as practices and social arrangements and institutions might, for example, open the way to reconceptualizations of core communication phenomena, like channel, interaction, message, organizing and group communication, or effects".
} 
como alicerce da pesquisa e a segunda consiste em traçar conexões entre as teses e os fatos.

\begin{abstract}
A função da teoria na pesquisa, isto é, a teoria concebida como parte integrante do processo metodológico, é realizar efetivamente, ser o meio de ruptura epistemológico em face das pré-noções do senso comum, através de um corpo sistemático de enunciados e de sua formulação conceitual visando captar e explicar os fatos. A teoria assim concebida impregna todo o processo concreto da pesquisa, é imanente a todos os procedimentos de observação e a todas as questões (problema de pesquisa) e respostas (hipóteses) que se apresentam ao objeto real. É no sentido amplo de confronto com o real, para apreendê-lo, que a teoria existe (LOPES, 2001, p. 124).
\end{abstract}

A instância metodológica inicial do trabalho (LOPES, 2001) consiste na adesão a um quadro teórico de referência que sustente a pesquisa sobre tecnologia, jornalismo e ubiquidade. Para isso, o primeiro passo da pesquisa é composto pela busca de autores e pesquisadores que auxiliam na construção do cenário e da fundamentação da tese.

Como se trata da construção de um estudo exploratório e qualitativo, a etapa seguinte à formulação teórica do objeto e a explicitação conceitual consiste na instância técnica, também proposta pelo modelo metodológico de Lopes (2001), uma vez que buscamos a realização de uma pesquisa de base empírica. A instância técnica é composta pela observação de quatro aplicativos para smartphone de jornais de referência nacional e internacional El País, The New York Times, The Guardian e O Estado de S. Paulo. A escolha dessas quatro marcas jornalísticas se deu em função de suas especificidades e de serem exemplos de publicações que estão investindo esforços na construção de produtos digitais voltados para smartphones. Além disso, a construção da amostra foi feita pensando em apontar exemplos diferentes, de vários países, mas que ao mesmo tempo representam algumas das marcas jornalísticas de referência no mercado. Outro motivo que levou à construção da amostra foi a viabilidade de visitar pessoalmente as redações desses veículos jornalísticos e, consequentemente, a adequação disso ao tempo de realização da tese e aos custos envolvidos neste objetivo.

Aliando o referencial teórico e a observação empírica, construímos um instrumento de análise (que é detalhado no Capítulo 5) que leva em consideração todo o referencial teórico abordado no trabalho. Esse instrumento tem como objetivo reunir todos os elementos, categorias e conceitos aqui discutidos e também balizar nossa observação empírica. A análise é relacionada ao objeto empírico levando em consideração usos e características desses aplicativos e do formato apresentado nesses 
produtos jornalísticos. Acreditamos ser possível chegar a uma seleção de exemplos para futuro comparativo e operacionalização dos dados na construção de possíveis modelos/exemplos de produção.

O método de observação utilizado no trabalho é o não participante. Além da observação dos produtos, também realizamos entrevistas com editores de todas as marcas que fazem parte da nossa amostra selecionada. Essas entrevistas semiestruturadas foram registradas em áudio e realizadas in loco nas redações dos jornais. O objetivo da realização de mais essa coleta de dados é oferecer ao leitor do trabalho um olhar com relação ao entorno que interage com o sistema da narrativa jornalística. O protocolo de realização da entrevista buscou identificar aspectos da produção de conteúdos com formato reconfigurado e/ou específico para a condição de mobilidade e ubiquidade, e identificar as posições da empresa com relação às mudanças ocorridas no jornalismo e as potencialidades oferecidas pelos dispositivos móveis digitais. Embora não seja objetivo principal do trabalho dar conta de todo o sistema e também do seu entorno, acreditamos ser valoroso, tanto para a realização da pesquisa quanto para o trabalho final, a possibilidade de ter contato com mais elementos que interagem e agenciam o consumo de informação jornalística via smartphones, na atualidade. 


\section{DISPOSITIVOS MÓVEIS E JORNALISMO UBÍQUO}

O objetivo deste capítulo é apresentar de forma mais aprofundada o contexto de nossa pesquisa e o conceito de jornalismo ubíquo, que consideramos essencial para a compreensão do trabalho que realizamos nos capítulos seguintes de coleta de dados e análises. Assim, na parte inicial focamos em apresentar dados e elementos que constroem o contexto vivido atualmente pela coletividade. Por isso, trazemos estatísticas e dados de acesso à internet, conexão e consumo de conteúdo via dispositivos móveis digitais. Também fazem parte deste capítulo os conceitos que acreditamos ser fundamentais para formar a discussão: mobilidade, ubiquidade e espaços híbridos. No momento seguinte, discutimos e aprofundamos a proposta de jornalismo ubíquo, visto enquanto algo mais abrangente daquilo que conhecemos como jornalismo móvel. Ao final, nosso objetivo é que o leitor tenha clareza do cenário que estamos tratando, ou seja, do recorte de tempo e espaço que fazemos para analisar nosso objeto de pesquisa. Além disso, também temos por objetivo que o leitor compreenda nossas escolhas e posições com relação aos conceitos tratados.

\subsection{Dados e contexto}

Como dissemos acima, nesta primeira parte do capítulo buscamos trazer dados e informações que fazem parte e constroem o cenário em que este trabalho é escrito e também a partir do qual observamos o objeto de pesquisa. Conforme dito no capítulo anterior, nesta pesquisa partimos de uma visão onde consideramos a tecnologia digital parte fundamental do modus operandi da coletividade ${ }^{20}$, um ator e não apenas uma ferramenta técnica inerte. Pellanda (2009) afirma que a comunicação móvel produz grandes impactos em diversas classes sociais brasileiras. O autor alega que o acesso constante e permanente, fortalecido pelos dispositivos móveis com possibilidade de uso

\footnotetext{
${ }^{20}$ Temos, obviamente, a compreensão de que há ainda muita desigualdade e exclusão digital no mundo (dos sete bilhões de habitantes do planeta, cerca de quatro bilhões ainda não acessam a rede), no entanto, sabemos que os operadores econômicos e políticos no mundo capitalista atuam a partir de uma lógica que envolve a tecnologia digital. Ainda que muitos sejam deixados de fora, bancos, imprensa, repartições públicas, universidades, escolas, hospitais, entre outros, incluíram em seu funcionamento a lógica da tecnologia digital, por isso optamos por uma ótica que privilegia este aspecto. Manovich (2001), por exemplo, defende que o computador e a tecnologia operam enquanto motores da nossa cultura e afirma que a produção cultural, coletiva e econômica da atualidade é fortemente dependente de computadores, softwares e conexão.
} 
de voz e dados, abre caminho para "um novo manancial de distribuição e colaboração de informações em um contexto onde os aparelhos são 'hiper-pessoais', pois eles são realmente usados por uma só pessoa, o que não ocorre necessariamente com o computador pessoal" (p. 11).

Pensando historicamente, a adoção dos dispositivos móveis digitais possui números sem precedentes. A Apple, de acordo Leber (2012), levou quase 25 anos para vender 67 milhões de computadores pessoais. O mesmo número foi alcançado em menos de cinco anos com iPads, iPhones e iPods. O rádio demorou 38 anos para alcançar uma audiência de 50 milhões de pessoas; a televisão, 13 anos; a Internet, quatro anos; e o primeiro smartphone, dois anos. Em 2011, tablets e smartphones já ultrapassavam os computadores pessoais em vendas nos Estados Unidos. Em 2016, os smartphones já são a principal via de acesso à internet em diversos países do mundo, incluindo o Brasil.

De acordo com Katz (2008), os dispositivos móveis digitais são responsáveis por modificações no espaço público e também no comportamento dos consumidores. Além disso, o estabelecimento de redes entre os dispositivos afeta todos os segmentos da vida, desde uma busca por emprego até o estabelecimento de compromissos ou encontros pessoais. Para ele, o estudo sobre os dispositivos móveis digitais é fundamental na medida em que, a partir disso, podemos compreender suas dinâmicas de uso, os formatos de conteúdo difundidos através deles e também as transformações que se estabelecerão na coletividade. Katz utiliza o termo “apparatgeist”, junção de dispositivo e espírito, para se referir a uma possível "era do telefone móvel”, à medida que os usuários transformam suas vidas e seus comportamentos a partir desses artefatos, atribuindo a elas, inclusive, qualidades transcendentais, onde o usuário vê o celular como uma "mente externa" e auxiliar.

O telefone móvel já é muito mais do que um dispositivo sofisticado. É um objeto cultural de pleno direito. E não só por sua extensa implantação social, senão porque, em um sentido plenamente biográfico e identitário, forma parte de nossa vida cotidiana, dos espaços de interação social e dos ritos cotidianos nos quais nos construímos como sujeitos e como sociedade (AGUADO; MARTINÉZ, 2008, p. 15) ${ }^{21}$.

\footnotetext{
21 Tradução da autora, trecho original: "El teléfono móvil es ya mucho más que un dispositivo sofisticado. Es un objeto cultural de pleno derecho. Y no sólo por su extensa implantación social, sino porque, en un sentido plenamente biográfico e identitário, forma parte de nuestra vida cotidiana, de los espacios de interacción social y de los ritos cotidianos en los que nos construimos como sujetos y como sociedades".
} 
A $11^{\text {a }}$ edição da Pesquisa sobre o uso das tecnologias da informação e comunicação nos domicílios brasileiros, a TIC Domicílios, realizada pelo Comitê Gestor da Internet no Brasil (CGI.br), por meio do Centro Regional de Estudos para o Desenvolvimento da Sociedade da Informação (Cetic.br), do Núcleo de Informação e Coordenação do Ponto BR (NIC.br), publicada em 2016, mostra que o telefone celular ultrapassou o computador pessoal como dispositivo mais utilizado para acessar a internet. Conforme os dados, $89 \%$ dos brasileiros com 10 anos ou mais acessaram a rede por esse tipo de dispositivo nos últimos três meses anteriores à pesquisa (os dados foram coletados entre novembro de 2015 e junho de 2016), o que, em números absolutos, significa que mais de 87 milhões de pessoas navegaram na internet pelo celular. Observado dentro de um comparativo, o percentual cresceu quase seis vezes desde 2011, quando a proporção era de $15 \%$.

A pesquisa também mostra que $82 \%$ dos usuários acessam a internet todos os dias ou quase todos os dias. Entre os domicílios brasileiros, $51 \%$ possuem um computador desktop na casa, número que se mantém estável nas duas últimas pesquisas. Computadores portáteis como notebooks estão em $64 \%$ das residências e tablets em $38 \%$. De acordo com o levantamento, a proporção de domicílios com acesso à internet no Brasil é de 51\%, o que em números absolutos indica que cerca de 34 milhões de residências possuem acesso à rede no país. As desigualdades sociais ficam mais expostas nesse dado, pois a maioria das casas conectadas faz parte das classes A e B. Na classe A, o acesso à internet é praticamente universal.

Com relação à conexão, $79 \%$ das casas pesquisadas possuem acesso sem fio à internet e $22 \%$ têm velocidade contratada de até $2 \mathrm{Mbps}$. O acesso via Wi-Fi dentro de casa cresceu 13 pontos percentuais em relação à pesquisa anterior, o que, segundo o levantamento, é mais um indicativo da adesão ao uso de smartphones e tablets, na medida em que esses dispositivos utilizam esse tipo de tecnologia. Entre os usuários de internet pelo celular, a conexão Wi-Fi é utilizada por $87 \%$ e o acesso via redes $3 \mathrm{G}$ e $4 \mathrm{G}$, por $72 \%$.

Ao todo, o percentual de brasileiros usuários de internet ${ }^{22}$ em 2016, também segundo a TIC Domicílios, foi de 58\%, o que corresponde a 102 milhões de usuários. Entre esses milhões de brasileiros que acessam a rede, a atividade mais realizada por

\footnotetext{
22 A pesquisa considera usuários de internet aqueles que utilizaram a rede nos três meses que antecederam a pesquisa. Ou seja, não são necessariamente pessoas que têm conexão à internet em casa.
} 
eles quando conectados é o envio de mensagens utilizando aplicativos como Messenger, WhatsApp ou Skype (85\%). Acessar plataformas de redes sociais online como Facebook, Twitter e Google+ também está entre as atividades mais frequentes citadas pelos entrevistados $(77 \%)$. Outras atividades também mencionadas foram o compartilhamento de conteúdo como textos, imagens e vídeos (66\%), o consumo de vídeos e filmes em sites de streaming como YouTube e Netflix (64\%), o envio de e-mails (60\%), a busca por informações de produtos e serviços $(58 \%)$ e a leitura de jornais ou revistas online (49\%).

Outra pesquisa que também apresenta o cenário de fortalecimento dos dispositivos móveis é a 2015 Brazil Digital Future in Focus ${ }^{23}$ realizada pela ComScore. De acordo com os dados, o sistema operacional Android, desenvolvido pelo Google, é responsável por mais de $70 \%$ dos aparelhos usados para acesso. Em segundo lugar, aparece o sistema $i O S$, usado em iPhones da marca Apple, com $15 \%{ }^{24}$. Esse indicativo está relacionado à popularização de smartphones mais acessíveis, na medida em que esses modelos, normalmente, possuem o sistema operacional Android.

Pode soar estranha uma adoção tão massiva da tecnologia móvel num país em desenvolvimento como o Brasil, no entanto, é justamente a particularidade desse tipo de tecnologia que faz com ela se espalhe tão rapidamente. Planos pré-pagos para celular são mais baratos do que planos de banda larga fixa, oferecidos pelas operadoras de telefonia, além disso, há locais remotos ou ocupados irregularmente onde a oferta de rede por cabos não existe. Pellanda (2009) afirma que a situação do Brasil se assemelha à da África, onde a telefonia móvel chegou antes da fixa, dada a dificuldade de implementação da rede. Além do mais, há categorias de smartphones com preços mais acessíveis quando comparados ao custo de um computador pessoal.

De acordo com a TIC Domicílios, em 2015, 35\% dos usuários de internet acessaram a rede somente pelo telefone celular. Esse uso exclusivo do telefone, segundo a pesquisa, ocorre entre os usuários de classes sociais menos favorecidas e também entre os moradores da área rural. Na população de classes D e E, $28 \%$ são usuários de internet e, dentre eles, $65 \%$ usam a rede apenas pelo telefone celular. Além do celular, a pesquisa também aponta o tablet como principal dispositivo de acesso à rede nos domicílios da

\footnotetext{
${ }^{23}$ https://www.comscore.com/por/Insights/Presentations-and-Whitepapers/2015/2015-Brazil-DigitalFuture-in-Focus

${ }^{24}$ Os tablets iPad também utilizam o sistema operacional $i O S$, porém não estão contabilizados no dado.
} 
classe $\mathrm{D}$ e E, indicando que esse também é um dispositivo com possibilidade de compra mais acessível do que o computador pessoal.

Katz (2008) comenta o fato da adoção massiva desses dispositivos entre a população de classes não tão favorecidas de países em desenvolvimento. Esse caráter, segundo ele, pode ser responsável por uma ampliação nas atividades e oportunidades econômicas nesses locais. Algo que podemos ver como já potencial no Brasil diante do crescente número de pessoas que utilizam o celular para trabalhar. Outro ponto levantado é a melhoria na comunicação das pessoas que possuem algum tipo de deficiência ou sem educação primária. Um exemplo são as mensagens de voz possíveis de serem enviadas pelo aplicativo de mensagens WhatsApp que facilitam a vida de quem não sabe ler e escrever e ficava excluído do envio de mensagens escritas e SMS.

Nos Estados Unidos, segundo o Pew Research Center ${ }^{25}$, 68\% dos adultos possuíam um smartphone em 2015, sendo que nos grupos com idades entre 18 e 29 anos e 30 e 49 anos, as porcentagens sobem para $86 \%$ e $83 \%$, respectivamente. Entre 2011 e 2015, o número de norte-americanos que possuem smartphones dobrou, de acordo com a pesquisa. No que diz respeito ao uso de internet ${ }^{26}, 84 \%$ dos adultos norte-americanos usam a rede, sendo que, mais uma vez, entre os grupos de 18-29 anos e 30-49 anos, as porcentagens sobem para $93 \%$ e $96 \%$, respectivamente.

No Reino Unido, sete em cada dez britânicos utilizam smartphones, de acordo com a pesquisa Ipsos Connect Technology Tracker Q1 2016. Quase 90\% dos adultos afirmam acessar a internet e, entre eles, 69\% utilizam um smartphone para o acesso. A pesquisa Mobile Consumer 2015, realizada pela empresa Deloitte (DELOITTE, 2015a), revela que 55\% dos usuários de smartphones acessam o dispositivo até 15 minutos depois que acordam e $20 \%$ utilizam já imediatamente ao acordar. O levantamento também aponta que o smartphone tomou, na atualidade, o lugar que era ocupado pelo computador há alguns anos.

Enquanto um computador era compartilhado com a casa, o smartphone é pessoal; o laptop pode ser carregado, mas não pode ser colocado no bolso ou na bolsa. Ao longo do tempo, o uso de smartphones pode se tornar mais generalizado, enquanto os computadores devem se tornar cada vez mais especializados. [...] A revolução dos smartphones ainda não completou dez anos e sua influência certamente não está terminada. Aparelhos novos e inovações na conectividade devem tentar-nos a nos tornar ainda mais

\footnotetext{
${ }^{25}$ http://www.pewinternet.org/2015/10/29/technology-device-ownership-2015/

${ }^{26} \mathrm{http}: / / \mathrm{www}$.pewinternet.org/2015/06/26/americans-internet-access-2000-2015/
} 
dependentes, ligados e distraídos por nossos smartphones (DELOITTE, 2015a, p. 9$)^{27}$.

Na Espanha, segundo a pesquisa Consumo Móvil 2015, também realizada pela Deloitte (2015b), 88\% dos espanhóis já possuem um smartphone. Dentre eles, mais de $50 \%$ utilizam o aparelho nos primeiros 15 minutos do seu dia, chegando a uma média de 41 vezes diárias em que o dispositivo é consultado. Ainda entre os espanhóis, o relatório Mobile en España y en el Mundo 2015, da consultoria Ditrendia, aponta que mais da metade da população usa a internet por pelo menos 30 minutos por dia via dispositivo móvel, e um em cada dez usuários faz um uso superior a quatro horas diárias (DITRENDIA, 2015).

Com um espectro amplo acerca do acesso à internet e do fortalecimento dos dispositivos móveis nos países que são de interesse desta pesquisa, cabe também apresentar aqui dados sobre o consumo de notícias em plataformas móveis digitais, uma vez que esse tipo de conteúdo é foco do trabalho. O Reuters Institute Digital News Report de 2016 mostra que, dentro da amostra total da pesquisa - 26 países -, 53\% dos usuários utilizam smartphones como dispositivos de acesso a notícias. No Reino Unido, por exemplo, o uso ultrapassou o de computadores para consumo de conteúdo jornalístico. Esta adoção, no entanto, é predominante em grupos de usuários mais jovens, com idades entre 18 e 44 anos. Na Espanha, o uso do smartphone como principal dispositivo para acesso de notícias evoluiu de 24\%, em 2015, para 34\%, em 2016. Entre adultos com menos de 45 anos, esse percentual chega a 50\% (NEWMAN et al., 2016).

De acordo com o relatório, o usuário de aplicativos no celular é mais interessado em notícias do que o usuário médio da $w e b$, mostrando-se mais instruído e propenso a pagar pelo conteúdo jornalístico consumido. Os dados também mostram um crescimento no uso de notificações por $p u s h^{28}$ de aplicativos para ter acesso a notícias na Espanha e uma manutenção dos índices já registrados nesse tipo de acesso nos Estados Unidos e

\footnotetext{
${ }^{27}$ Tradução da autora do trabalho, trecho original: "While a PC may have been shared by:șẹ:a household, the smartphone is personal; the laptop can be carried, but cannot be slipped into a pocket or purse. Over time, the smartphone's usage may become more general, while the PC's may become increasingly specialized. The smartphone revolution is not yet ten years old, and its work is certainly not done. Imminent device and connectivity innovations should tempt us into becoming yet more reliant on, wedded to and distracted by our smartphones".

${ }^{28}$ Notificações por push são alertas ou avisos enviados para o dispositivo móvel automaticamente, sem que o usuário precise solicitar a informação. O termo push (empurre, em inglês) é utilizado para indicar que os conteúdos são empurrados para o usuário.
} 
Reino Unido. Pela manhã, um terço dos usuários prefere consumir notícias pelo smartphone.

Dentro da amostra total da pesquisa, $51 \%$ dos usuários afirmaram acessar notícias através das redes sociais online, sendo o Facebook o serviço predominante na preferência (44\%). No Brasil, o total de pessoas que usa as redes sociais para se informar chega a $72 \%$.

Existem duas mensagens importantes e contraditórias no relatório deste ano. De um lado, vemos publishers perdendo o controle da distribuição, alguns consumidores não percebendo de onde o conteúdo vem e a crescente influência de plataformas e algoritmos. Ao mesmo tempo, nós percebemos, quantitativa e qualitativamente, que as pessoas ainda querem, valorizam e se identificam com marcas tradicionais de jornalismo (NEWMAN et al., 2016, p. 29$)^{29}$.

No país, o número de usuários do Facebook, segundo a pesquisa, é de mais de 83 milhões. Além da rede social online, o segundo serviço mais utilizado para consumo de notícias é o mensageiro WhatsApp, com mais de 100 milhões de usuários, o que significa que quase um em cada dois brasileiros tem o aplicativo instalado no celular. Apesar de muito ligados às redes sociais, os brasileiros apresentaram a terceira maior taxa, entre 26 países, de usuários que pagam por algum tipo de conteúdo noticioso $(22 \%)$.

Entre as conclusões do relatório, os autores colocam que a contradição entre o consumo de jornalismo via redes sociais e a manutenção da valorização das marcas tradicionais (exposta na citação acima) pode ser explicada a partir do contexto individual de consumo, do tipo de notícia e da complexa relação que os usuários possuem com marcas jornalísticas. Segundo os pesquisadores, o público está, cada vez mais, acessando notícias a partir de múltiplas e diferentes plataformas, sejam aplicativos de marcas, agregadores de conteúdo ou redes sociais online. Para eles, as empresas podem atravessar esse mar de incertezas com três atitudes: a) entrega de conteúdo consistente e focado na audiência; b) construção de propósito na identidade e no conteúdo; e, c) ser excelente na distribuição de conteúdo dentro do atual ambiente em constantes mudanças (NEWMAN et al., 2016).

\footnotetext{
${ }^{29}$ Tradução da autora, trecho original: "There are two contradictory but important messages in this year's data. On the one hand we see publishers losing control of distribution, some consumers not noticing where content comes from, and the growing influence of platforms and algorithms. And yet at the same time we find, both in our survey data and our qualitative work, that people still want, value, and identify with traditional news brands".
} 
Nesse novo ambiente multiplataforma no qual estamos inseridos, o relacionamento das pessoas com o conteúdo se torna portátil, personalizado e participativo. O conteúdo jornalístico, mais especificamente, passa a ser "onipresente" e acessado em múltiplos formatos e dispositivos (PURCELL et al., 2010). A mudança tecnológica é acompanhada por uma mudança cultural e tem reflexos econômicos, sociais e políticos. As formas de produção, consumo e distribuição do conteúdo jornalístico são profundamente alteradas, causando transformações na indústria, trazendo novos atores para o contexto e abrindo espaço para um consumidor mais ativo.

Aguado et al. (2013) defendem que os dispositivos como os smartphones acarretam um processo profundo de transformação, não podendo ser considerados como meras ferramentas adicionais ao sistema já existente.

É antes de tudo uma tela social, expansiva e envolvente, que penetra nos alvéolos de nossas interações cotidianas com uma fusão singular de comunicação e conteúdo e que, por isso mesmo, tende a incluir em seus cenários de uso outras telas e outras formas de consumo ${ }^{30}$ (AGUADO et al., 2013, p. 16).

É por esse processo de transformação no consumo de conteúdo ser tão afetado e transformado a partir da inserção desses novos atores não humanos no contexto, que acreditamos ser importante encontrar uma forma de compreender o jornalismo a partir de um conceito que abarque, de forma mais ampla, todas essas alterações vividas nos últimos anos. Não nos parece suficiente continuar olhando para o jornalismo somente a partir das noções e conceitos desenvolvidos no surgimento da internet comercial, e isso faz com que busquemos mais e novos conceitos auxiliares, a fim de que o debate se amplie e se atualize. É esta discussão que propomos nos próximos itens deste capítulo.

\subsection{Mudanças no jornalismo}

O jornalismo costuma ser tipificado por terminologias e conceituações que se constituem, entre outras coisas, a partir do entendimento do seu suporte técnico, como nos casos, por exemplo, do jornalismo impresso, telejornalismo e radiojornalismo. Essas

\footnotetext{
${ }^{30}$ Tradução da autora, trecho original: "Es, ante todo, una pantalla social, expansivo y envolvente, que penetra en los alvéolos de nuestras interacciones cotidianas con una fusión singular de comunicación y contenido y que, por eso mismo, tiende a incluir en sus escenarios de uso otras pantallas y otras formas de consume".
} 
denominações, no entanto, não carregam consigo apenas a questão do suporte, mas também de um modelo de produção e características específicas do produto final. Os produtos e empresas jornalísticas vêm enfrentando uma série de transformações há pelo menos 20 anos, desde o surgimento da internet comercial e, consequentemente, da predominância das tecnologias digitais de comunicação e informação. Com isso, as tipologias que buscam identificar diferentes tipos de jornalismo ganham força, fazendo surgir diversas denominações para a produção transformada pela rede e pelo desenvolvimento tecnológico: jornalismo digital, jornalismo online, webjornalismo, ciberjornalismo, jornalismo móvel, entre outros. Cada denominação carrega consigo especificidades ligadas ao meio a que se refere e também a características de produção e consumo. Para diferenciar algumas dessas nomenclaturas é importante que comecemos a partir de preceitos básicos, como a noção de internet e web.

A internet se refere a uma plataforma virtual que une um conglomerado de redes em escala mundial e permite acesso e troca de inúmeros tipos de dados. A internet surgiu em 1969, com a Arpanet, criada pelo Departamento de Defesa dos Estados Unidos, através de financiamento da Advanced Research Projects Agency (Arpa). O objetivo do projeto, até então militar, era desenvolver uma rede de computadores descentralizada, onde as máquinas estivessem interligadas e, no caso de uma guerra, se um ponto fosse destruído, os outros poderiam manter a comunicação e a transmissão de dados entre as unidades militares.

A web (World Wide Web) é somente uma parte da internet e se refere a um ambiente que fornece informações em hipermídia, representando apenas um dos diversos serviços oferecidos pela primeira. A web foi desenvolvida no início da década de 1990 pelo físico Tim Berners-Lee, da Organização Europeia para Pesquisa Nuclear. O objetivo de Lee era criar uma interface mais amigável para os usuários da rede, que não envolvesse códigos de programação e que pudesse tornar mais fáceis as comunicações. $\mathrm{O}$ primeiro servidor web funcionou no próprio centro de pesquisa de Lee e, em dezembro de 1991, o primeiro servidor fora da Europa foi instalado nos Estados Unidos fazendo com que, a partir daí, a web se tornasse global. A partir de então, a web seria uma espécie de interface da internet que se tornaria global e reconhecida por todos através das URL's das páginas que iniciam com $w w w$, acessadas pelos softwares conhecidos como navegadores (CASTELLS, 2001). 
É por isso que não podemos considerar o webjornalismo como sinônimo, por exemplo, do jornalismo digital, já que a primeira denominação implica numa ligação direta com a web, isto é, de conexão e interação com páginas/interfaces da internet através de navegadores, o que não é o cenário completo do jornalismo digital. O jornalismo digital estaria, então, ligado a tecnologias mais abrangentes que o webjornalismo. Isso não quer dizer que a importância desse conceito seja diminuída. O nascimento do conceito de webjornalismo trouxe consigo a proposição de novas linguagens e formas de reportar na web e devido à web, reorganizando a disposição da notícia, criando novos modelos como o proposto por Canavilhas (2005), o da substituição da pirâmide invertida para a deitada, o que remete a um diferente tipo de leitura na interface, a horizontal.

Quanto ao jornalismo digital, em essência, podemos dizer que é aquele feito com e para as tecnologias digitais. No entanto, essa configuração e terminologia ainda parece não dar conta de todos os elementos atuais que afetam e transformam a produção jornalística, na medida em que é vaga. Que jornalismo não é digital? O próprio jornalismo impresso pode ser considerado digital na medida em que é escrito e diagramado em computadores, suas imagens são feitas em câmeras fotográficas digitais e parte de sua circulação também se dá a partir de dispositivos de tecnologia digital. Outros pesquisadores usam a tipologia jornalismo online, o que também limita a conceituação a um jornalismo feito estritamente com conexão permanente e ativa à internet, restringindo comunicações offline e via bluetooth, por exemplo. Além disso, também caímos na mesma inexatidão do termo digital.

Em direção à outra terminologia, pensamos que o jornalismo para além do online e do webjornalismo faria parte do mundo virtual não palpável, classificado como ciberespaço. Assim, as novas formas de produção e distribuição do jornalismo dentro do ciberespaço levariam à denominação de ciberjornalismo. A partir dessa noção, Salaverría (2005) propõe que o ciberjornalismo se constitui como uma "especialidade do jornalismo que usa o ciberespaço para investigar, produzir e, sobretudo, distribuir conteúdo jornalístico"31 (p. 21). Esse termo foi e é importante para marcar um momento da produção jornalística e até mesmo um momento da discussão acadêmica acerca do jornalismo e do ciberespaço. No entanto, com a evolução dos sistemas tecnológicos e,

\footnotetext{
${ }^{31}$ Tradução da autora, trecho original: "la especialidad del periodismo que emplea el ciberespacio para investigar, producir $\mathrm{y}$, sobre todo, difundir contenidos periodísticos."
} 
consequentemente, das definições teóricas ligadas a eles, torna-se necessário abrir espaço para discutir a noção de ciberespaço e sua validade no contexto atual, para que assim possamos explicar o porquê de nossa não adoção dos termos ciberespaço e ciberjornalismo, e a proposição de um termo que dê conta melhor do atual cenário digital da comunicação.

\subsection{Do ciberespaço aos espaços híbridos}

O termo ciberespaço foi cunhado por Willian Gibson no livro de ficção científica "Neuromancer", de 1984. Na obra, o autor apresenta o conceito para identificar um "lugar" separado do físico, outro espaço separado para a circulação de informação pela tecnologia eletrônica. Essa noção de ciberespaço enquanto um "outro lugar” ganhou espaço com a chegada da internet comercial na década de 1990. Santaella (2010) fala num crescimento, a partir daí, da "metáfora do computador como um mundo alternativo, além e divorciado do mundo físico" (p. 68). Pierre Lévy (1999), um dos primeiros autores a teorizar sobre o ciberespaço, apresenta uma noção aberta que não distingue nem une completamente os "lugares", ciber e físico.

\footnotetext{
Eu defino o ciberespaço como o espaço de comunicação aberto pela interconexão mundial dos computadores e das memórias dos computadores. Essa definição inclui o conjunto dos sistemas de comunicação eletrônicos (aí incluídos os conjuntos de redes hertzianas e telefônicas clássicas), na medida em que transmitem informações provenientes de fontes digitais ou destinadas à digitalização. Insisto na codificação digital, pois ela condiciona o caráter plástico, fluido, calculável com precisão e tratável em tempo real, hipertextual, interativo e, resumindo, virtual da informação que é, parece-me, a marca distintiva do ciberespaço (LÉVY, 1999, p. 92-93).
}

Partindo desse princípio da internet comercial para o momento em que vivemos hoje, com acesso ubíquo e dispositivos móveis digitais popularizados, autores começam a relativizar a noção de ciberespaço enquanto algo que não seja, efetivamente, o próprio espaço em que vivemos e damos sentido às nossas vidas. Thomas (2006) afirma que no momento em que chegamos à era da "internet das coisas" temos atores não humanos interagindo com humanos, mas também interagindo entre si, sem nenhuma agência humana como mediadora. Para ela, então, a pressuposta distinção entre humano e máquina vem se desfazendo cada vez mais, na medida em que ao realizarmos atividades como enviar um e-mail, trocar dados com um site ou comprar um produto pela rede, 
"nós estabelecemos um compromisso entre corpo, tecnologia e natureza, permitindo que nossos dados se tornem parte de uma base de conhecimento de uma organização" (p. $388)^{32}$. De acordo com a autora, nossa característica "carnal" não faz com que fiquemos de fora dessa equação/compromisso, pelo contrário, há uma retroalimentação entre os elementos da cadeia.

Nós crescemos acostumados com o conceito binário de online/off-line, mas infelizmente esse conforto pode estar prestes a ter um fim. [...] Em breve, não haverá viagens entre o ciberespaço e o espaço 'real' porque não haverá nenhuma fronteira entre eles (THOMAS, 2006, p. 388) ${ }^{33}$.

A não necessidade de sentar em frente a uma tela grande e decidir para onde "navegar no ciberespaço" é um dos processos que altera o status do conceito. Os dispositivos móveis e a conexão ubíqua constante tornam o usuário e a rede profundamente integrados, sendo que suas existências ficam quase que indissociáveis. Pang $^{34}$ (apud Santaella, 2010) defende que os dispositivos móveis remodelam as relações entre usuários e tecnologia, engajando novos sentidos na interação. Há um "apagamento de fronteiras", fronteiras essas que fortaleciam a noção de ciberespaço enquanto um "lugar" diferente a ser acessado. "Isso subverte a ideia de que ir online significa ir a outro lugar. [...] Agora a informação pode estar nos lugares e nosso corpo agir como browser" (p. 69).

Apesar de trazer a contribuição de Pang, a própria Santaella (2010) defende a manutenção da importância da noção de ciberespaço. Para a autora, a dicotomia entre mundo físico e ciberespaço é simplista e maniqueísta. Usando ou não o termo ciberespaço, estamos nos referindo a "um espaço de interação, cujo acesso se dá por meio de interfaces dos mais diversos tipos que permitem navegar a bel-prazer pela informação hipermidiática" (p. 71), e acrescenta que "negar o ciberespaço significa negar um meta-hiperdocumento pervasivo que cresce de modo iterativo e que permeia todas as esferas, camadas e todos os meandros da vida humana. Os dispositivos móveis não apagaram o ciberespaço. Ao contrário, tornaram-no ainda mais onipresentes" (p. $71)$.

\footnotetext{
${ }^{32}$ Tradução da autora, trecho original: "We make a trade-off between body, technology and nature by allowing our data to become part of that organization's knowledge base".

${ }^{33}$ Tradução da autora, trecho original: "We have grown used to the binary of online/offline, but unfortunately that comfort may be about to come to an end. [...] Soon there will be no travelling between cyberspace and 'real' space, because there will no longer be any borders between the two."

${ }^{34}$ PANG, A. S.-K. Mobility, convergence, and the end of cyberspace. In: NYÍRI, K. (ed.). Integration and ubiquity. Towards a philosophy of telecommunications convergence. Viena: Passagen Verlag, 2008.
} 
O ciberespaço deve ser concebido, portanto, como um mundo virtual global, hipercomplexo, mas coerente, independente de como se acede a ele e como se navega nele. Além disso, há várias maneiras de entrar-se no ciberespaço. [...] Enfim, o ciberespaço está agora mais presente do que nunca, tão presente a um simples toque de dedos em levíssimos dispositivos sempre na palma de nossas mãos, que nem sequer nos damos conta de estarmos ao mesmo tempo no ciberespaço e fora dele, pisando o chão e simultaneamente ubíquos, viajando, pousando, entrando e saindo de espaços de informação e de comunicação à mesma velocidade com que nossos olhos piscam (SANTAELLA, 2010, p. 88 e 89).

No entanto, a própria autora, alguns anos depois, coloca que a condição da existência contemporânea é a ubiquidade. Para Santaella (2013), is so quer dizer que estamos dentro e fora de um lugar ao mesmo tempo, ausentes e presentes no mesmo instante. "Corpo, mente e vida ubíquas" (p. 16). Para a autora é justamente a existência de um ciberespaço que permite que se tenha um caráter de vida ubíqua na atualidade. Para ela, o espaço em que vivemos, quando conectados, é uma interseção entre o físico e o ciberespaço, logo a sua existência não seria possível caso decretássemos a morte do ciberespaço. No entanto, não estamos decretando aqui a morte do ciberespaço como seu fim, mas sim como sua conquista do espaço por completo, mais do que morte, estamos decretando a ampliação do ciberespaço. Que outro contexto possível para a condição de um ser totalmente ubíquo se não aquele em que ciber e físico já não se distinguem e formam uma unidade só? Além disso, se os dispositivos móveis tornaram o ciberespaço onipresente, não seria mais adequado nos referirmos a ele como o próprio espaço de realização das interações sociais? Como o próprio espaço de realização da coletividade? Esse espaço de interação, ao qual a autora se refere, não é o próprio espaço em que vivemos?

Miller e Slater (2000) afirmam que a noção de ciberespaço como um não-lugar remonta a uma "primeira geração" da literatura sobre internet. Segundo os autores, ao contrário do que se pensava, a internet é composta por inúmeras tecnologias usadas por uma ampla diversidade de pessoas em múltiplos lugares do mundo. Além disso, para que seja possível pensar e problematizar um tema relacionado à internet não se deve partir do ponto que o objeto é um "não-lugar". Ao partir desse ponto, no qual a virtualidade é tomada como a característica principal da internet, parte-se de uma noção de que ela estaria em contraposição ou desincorporada do mundo real. Ao contrário disso, é preciso partir da internet e da própria tecnologia enquanto um espaço coletivo, que existe dentro 
das estruturas do dito "mundo real". Ou seja, o que os autores querem dizer, baseando-se também em Latour, é que não existe um dualismo entre tecnologia e coletividade/realidade. A relevância está justamente no meio desse dualismo que propõe que uma coletividade se aproprie de uma tecnologia na cultura material, que não pode ser reduzida a um lado ou a outro.

Em 2006, Pang defendeu a ideia de que o ciberespaço estava "morto". Em seu $b \log ^{35}$ na época, o autor se dedicava a desenvolver diversas postagens que ratificavam sua proposta. Para ele, o termo ciberespaço foi historicamente importante como uma forma de compreensão dos computadores e seus espaços em nossas vidas. Além disso, o termo também teria servido para criar a ideia de um espaço separado daquele habitado por pessoas e coisas, no qual está a informação trocada a partir da tecnologia eletrônica. “O ciberespaço prometeu um mundo livre dos limites do mundo material, das restrições da geografia e dos prejuízos das interações sociais, mas na realidade, a informação tem uma vida material e é interpretada - e afetada - pelo contexto geográfico e social”,36 (PANG, 2007, p. 221).

Essa ideia, segundo ele, tende a desaparecer à medida que a internet se move cada vez mais para fora dos desktops, incorporando-se aos espaços, coisas e mentes. No mesmo ano, em artigo para a revista Wired $^{37}$, Pang busca a opinião de diversos autores sobre a questão do ciberespaço, apresentando, por exemplo, a opinião de Vint Cerf, um dos fundadores da internet, que defende o uso do termo computação ubíqua. Para corroborar ainda mais suas afirmações, Pang apresenta as ideias de Shappiro (1998), que bem antes dele já defendia a ideia de que o ciberespaço não é outro lugar diferente daquele em que estamos.

Em particular, nós não estamos bem servidos com a ideia de que o ciberespaço é um "lugar" autônomo. Essa concepção implica erroneamente que as interações online, são, ou deveriam ser, governadas por um corpo de leis próprio. Ela sugere que o que acontece "lá" está de alguma forma desconectado do que acontece "aqui". Ao fazer isso, ela nos distrai do reconhecimento de que a significância real do ciberespaço não está no fato de estar em outro lugar, mas sim no fato de ele estar crescentemente mais perto de nós. De fato, minha discussão aqui é que o ciberespaço está desaparecendo.

\footnotetext{
${ }^{35} \mathrm{O}$ blog de Pang já não está mais disponível e no ar. O acesso a ele foi realizado a partir da ferramenta Web Archive <http://web.archive.org/web/20060207111212/http://www.endofcyberspace.com> Acesso em ago. 2016.

${ }^{36}$ Tradução da autora, trecho original: "Cyberspace promised a world free of the limits of the material world, the constraints of geography, and the prejudices of social interactions; but in reality, information has a material life, and is interpreted in - and affected by - social and geographical context."

${ }^{37} \mathrm{https}: / / \mathrm{www}$.wired.com/2006/02/cyberspace-is-dead/
} 
E curiosamente, à medida que o ciberespaço desaparece ele se torna cada vez mais poderoso, finalmente assumindo a habilidade de transformar ou até mesmo abalar as fundações políticas e legais de nossa sociedade (SHAPPIRO, 1998, ONLINE) $)^{38}$.

Shappiro (1998) explica que ao criticar a noção clássica de ciberespaço, não busca diminuir a importância do termo, mas sim ressaltar o tamanho de sua significância, indicando que esse é muito importante para crermos que está em outro lugar que não aqui. Na medida em que o ciberespaço se funde ao próprio espaço de vida do ser humano, ele se torna ainda mais significativo e indispensável. Ao dizer que o ciberespaço está desaparecendo, o autor não quer dizer que ele some, mas sim que se torna tão intrínseco ao cotidiano que não o vemos como algo separado das interações que realizamos constantemente com artefatos e pessoas.

O autor defende que Gibson (1984) utilizou o termo para se referir a uma “experiência muito específica de realidade virtual”. Segundo ele, John Perry Barlow e Mitchell Kapor, autores do manifesto "Across the Eletronic Frontier", foram os responsáveis por estender a metáfora para identificar um lugar onde as interações online ocorrem. A continuidade do termo pode ter ocorrido por um "acidente de semântica" ou porque, alguns autores, consideravam que a metáfora era útil, pois descrevia a experiência da comunicação mediada por computador. No princípio da rede, na década de 1990, o conceito ajudava a descrever o momento de transformação tecnológica que tomava conta do mundo, no entanto, com o passar do tempo (Shappiro diz em seu artigo que "em 2010 a internet será diferente") o uso e a presença da técnica se tornam cada vez mais familiares, fazendo parte do "lugar" em si no qual estamos.

Na medida em que o termo ciberespaço é questionado, outros autores optam por diferentes conceitos que explicam o espaço atual no qual interagimos. Souza e Silva (2006) apresenta a ideia de espaços híbridos para indicar aquilo que surge quando as comunidades online migram para o espaço físico através das interfaces dos dispositivos móveis. A autora propõe que se amplie o conceito de interface para uma noção social, que indica uma interface de um dispositivo capaz de transformar as relações

\footnotetext{
${ }^{38}$ Tradução da autora, trecho original: "In particular, we are not well served by the idea that cyberspace is an autonomous "place." This conception wrongly implies that online interactions are, or should be, governed by their own body of law. It suggests that what happens "there" is in some way unconnected to what happens "here." In so doing, it distracts us from recognizing that the real significance of cyberspace is not in its being elsewhere but, quite the opposite, in its coming increasingly closer to us. Indeed, my contention here is that cyberspace is disappearing. And curiously, as cyberspace disappears it becomes ever more powerful, ultimately assuming the ability to transform or even undermine the legal and political foundations of our society."
} 
comunicacionais entre os atores e também o espaço no qual elas ocorrem. Essa seria a interface social do dispositivo móvel digital, que transforma a maneira como as pessoas circulam na cidade, trocam informações, interagem com atores não humanos, constroem relacionamentos amorosos e consomem conteúdo. Nesse sentido, os dispositivos móveis criam uma relação mais dinâmica com a internet em comparação ao computador pessoal, por exemplo, sendo essa relação construída nas atividades diárias e no contexto espacial momentâneo do usuário. Toda essa reformulação de interações faz com que não seja possível separar o espaço físico do digital, criando um espaço híbrido, composto por usuários, dispositivos móveis, conexões e intercâmbios permanentes.

O conceito de ciberespaço aplicado à internet foi responsável primeiro pela nossa visão de físico e digital como espaços desconectados, segundo pela nossa ênfase nos nós da rede em vez de na sua estrutura espacial e, finalmente, pela visão utópica de um futuro no qual espaços sociais apareceriam, principalmente, online. Telefones móveis transgridem essa relação tradicional com a internet porque eles são capazes de incorporar a internet nos espaços públicos. Em função de que cada mudança na interface transforma não apenas as relações sociais que essa medeia, mas também o espaço em que estão incorporadas, a noção de espaços híbridos encoraja a redefinição de espaços físicos e digitais. Por essa razão, o conceito de espaços híbridos surge para suprir uma lacuna aberta quando a internet se tornou móvel e quando comunidades, previamente formadas no ciberespaço, puderam ser encontradas em espaços (híbridos) urbanos (SOUZA E SILVA, 2006, p. 273) ${ }^{39}$.

Souza e Silva cita como um dos exemplos mais evidentes desse espaço híbrido, o surgimento dos games de realidade híbrida, que permitem que o usuário utilize o espaço da cidade como tabuleiro do seu jogo. Na atualidade, podemos pensar num dos mais recentes sucessos da indústria de games: Pokémon $G o^{40}$. Sendo um jogo que ocorre dentro do espaço físico (mas também digital) e do caminho percorrido pelo usuário, transformando locais físicos em "pokéstops" e centros de treinamento, não é possível dizer que Pokémon Go ocorre num ciberespaço distinto daquele físico ocupado pelo usuário. O espaço é híbrido, múltiplo, físico e digital, sem distinção entre o que está na tela do smartphone e o que podemos tocar ao nosso redor. "O usuário já não precisa

\footnotetext{
39 Tradução da autora, trecho original: "The concept of cyberspace applied to the Internet was responsible first for our view of physical and digital as disconnected spaces, second for our emphasis on the nodes of the network instead of its spatial structure, and finally for the utopian view of a future in which social spaces would emerge mostly online. Mobile phones transgress this traditional relationship with the Internet because they are able to embed the Internet in public spaces. Because every shift of interface transforms not only the social relationships it mediates but also the spaces in which it is embedded, the notion of hybrid spaces encourages the redefinition of physical and digital spaces. For this reason, the concept of hybrid spaces arises to supply a gap opened when the Internet became mobile and when communities previously formed in cyberspace could be found in urban (hybrid) spaces."

${ }^{40} \mathrm{http}: / / \mathrm{www}$.pokemongo.com
} 
perceber a presença da tecnologia, pois ela trabalha para ele de forma invisível em qualquer lugar, dando origem aos termos: ubíquo e pervasivo" (KIRNER; SISCOUTTO, 2007, p. 4).

Além disso, segundo Souza e Silva, a interface através da qual interagimos precisa ser considerada de forma diferente. Enquanto a interface do computador pessoal é estática, demandando que o usuário esteja parado na sua frente para acessar a rede, no dispositivo móvel digital, a interface anda com o usuário, ele "carrega" sua conexão consigo, enfatizando sua ubiquidade. "Como consequência, a mobilidade se torna parte do processo de conexão ao digital e exploração dos espaços híbridos. A conexão via dispositivos móveis é fundamentalmente diferente da conexão via computadores desktop" (SOUZA E SILVA, 2006, p. 268).

Estamos fortalecendo o caráter de nômades digitais na medida em que podemos navegar por diversos "lugares" sem deixarmos o "lugar" físico que ocupamos. Ao mesmo tempo, esses "dois lugares" não são distintos ou cotidianamente diferenciados, pois a evolução da mobilidade informacional faz com que o rompimento nas limitações de espaço e tempo se torne corriqueiro para os sujeitos. O acesso aos dispositivos móveis e à conexão ubíqua permanente é parte da comunicação cotidiana, criando os espaços híbridos aos quais Souza e Silva (2006) se refere, ou então os territórios informacionais, conceito apresentado por Lemos (2009). "Os nômades virtuais buscam novos territórios, os territórios informacionais" (p. 31). Para André Lemos, o território informacional é a interseção entre o espaço físico e o ciberespaço. Entretanto, podemos ainda falar de interseção? Não teria essa interseção abarcado os próprios conjuntos dos quais ela fazia parte, na medida em que não conseguimos mais distinguir esses conjuntos separadamente?

O próprio André Lemos, sem invalidar o conceito de ciberespaço, fala sobre um momento de "download do ciberespaço", onde esse "pinga nas coisas" e cria ambientes de conexão ubíqua em todos os lugares. Sendo assim, vemos o território informacional proposto por Lemos não como uma interseção, mas como o espaço em si no qual vivemos, na medida em que não é mais possível distinguir o ciber do físico. Estamos, então, num espaço híbrido onde a mobilidade e a conexão ubíqua permanente são fundamentais para a compreensão das interações, dos conteúdos jornalísticos consumidos pelas pessoas e também da construção desses produtos. Como o próprio autor propõe, o território informacional é composto por "uma complexidade de 
dimensões físicas, simbólicas, econômicas, políticas, aliadas a bancos de dados eletrônicos, dispositivos e sensores sem fio, portáteis e eletrônicos, ativados a partir da localização e da movimentação do usuário" (LEMOS, 2009, p. 33).

Essa constituição de espaços híbridos e também todas as características específicas dos dispositivos móveis fazem com que busquemos uma diferente e mais adequada caracterização do jornalismo produzido para esses dispositivos e também, consequentemente, uma proposta de nomenclatura. Conforme a discussão proposta até aqui, vimos que tratar da prática e do consumo jornalístico na atualidade somente a partir da noção de ciberjornalismo é limitante, na medida em que o próprio conceito de ciberespaço também se tornou limitado. Ao adotarmos a noção de espaços híbridos, como parte fundamental da fundamentação teórica deste trabalho, torna-se necessário pensar o jornalismo dentro deste espaço aliado à noção de ubiquidade, conexão permanente e mobilidade ampliada.

\subsection{Do jornalismo móvel ao jornalismo ubíquo}

No começo da década de 2000, Mielniczuk (2003) identificou três gerações ao longo do desenvolvimento do jornalismo junto às tecnologias digitais de comunicação. A primeira geração é a da transposição, que podemos localizar a partir da metade da década de 1990, onde a migração dos jornais para a internet se dava a partir da simples transposição do jornal impresso para o site, muitas vezes com apenas um arquivo em formato $p d f$ disponível para download, com atualização a cada $24 \mathrm{~h}$ e páginas estáticas. A segunda geração é chamada de fase da metáfora, onde os sites dos jornais impressos passaram a se inspirar no próprio modelo do jornal impresso para sua organização e desenho na tela, mas já possuindo alguns elementos novos e ligados à produção digital. A terceira geração é a que coincide com uma produção mais ligada ao conceito de webjornalismo e suas respectivas características como atualização contínua, hipertextualidade, multimidialidade e interatividade.

Barbosa (2007), ao desenvolver o conceito de Jornalismo Digital em Base de Dados, propõe uma quarta geração para o jornalismo, onde o uso de bases de dados já se torna mais conectado aos sistemas publicadores e também a novos formatos de reportagem e apresentação da notícia, criando assim padrões mais dinâmicos de construção dos sites. O JDBD é aquele em que as bases de dados atuam como 
definidoras da estrutura, organização, composição, apresentação e circulação dos conteúdos jornalísticos através de multiplataformas e dispositivos.

As fases, obviamente, não são excludentes entre si, nem possuem período exato marcado no tempo. Atualmente, Barbosa (2013) situa os dispositivos móveis digitais enquanto agentes propulsores de inovação no jornalismo, dentro de um novo ciclo que indicaria uma quinta geração no desenvolvimento do jornalismo.

Neste contexto, as mídias móveis, especialmente smartphones e tablets, são os novos agentes que reconfiguram a produção, a publicação, a distribuição, a circulação, a recirculação, o consumo e a recepção de conteúdos jornalísticos em multiplataformas (BARBOSA, 2013, p. 42).

Como podemos ver na figura 2, a autora apresenta uma série de aspectos que fazem parte da evolução jornalística ao longo das gerações propostas. A quinta geração seria aquela que congrega não apenas as características de todas as anteriores, mas também elementos como os dispositivos móveis digitais e os aplicativos produzidos por empresas jornalísticas para distribuição de conteúdo através deles. A autora utiliza o termo autóctone para se referir a aplicativos que são criados para distribuir conteúdo exclusivo para essas plataformas, com material que não está presente em outras mídias. 
Figura 2 - Estágios de evolução do jornalismo

\section{ESTÁGIOS DE EVOLUÇÃO JORNALISMO EM REDES DIGITAIS}

\section{BASE DE DADOS COMO COMPONENTE PRIMORDIAL}

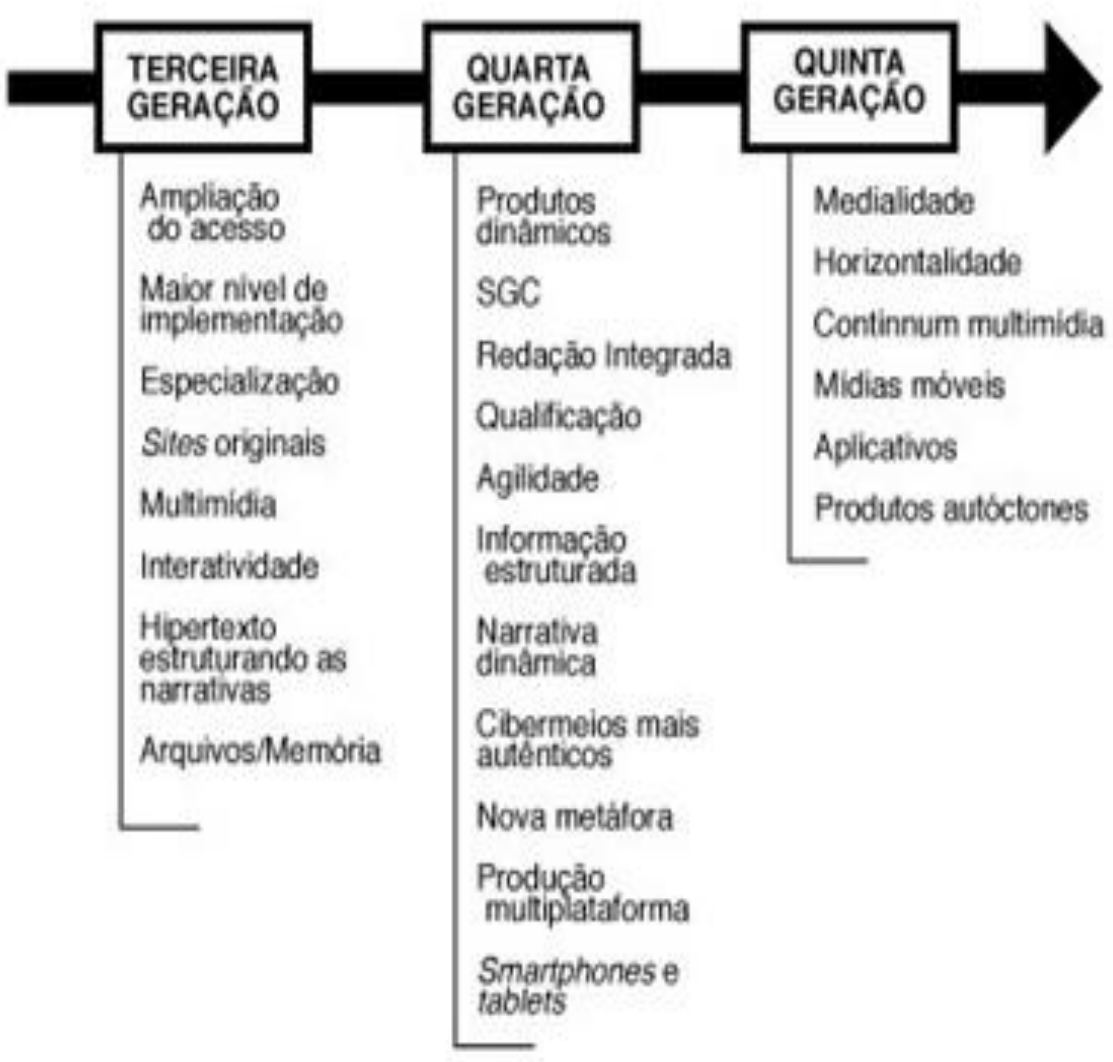

Fonte: Barbosa (2013)

O conceito proposto por Barbosa é de extrema importância desde a sua criação até o momento para chamar a atenção para diversos aspectos do novo caráter da produção jornalística diante da evolução tecnológica. As bases de dados, até poucos anos, quase desconhecidas dos profissionais da redação, passam a ser fundamentais no processo de produção do conteúdo jornalístico, assim como também são claramente fundamentais para o funcionamento de qualquer sistema/plataforma digital, seja ele jornalístico ou não. Entretanto, a mudança provocada pelos dispositivos móveis digitais chama a nossa atenção não apenas para as bases de dados, elementos já relevantes durante a evolução do jornalismo, mas para novas características como a mobilidade potencializada e a ubiquidade. É no intuito de abarcar também es ses novos elementos 
dentro de uma conceituação e terminologia que buscamos uma diferente proposta neste trabalho.

Barbosa não propõe um novo termo para se referir ao jornalismo que é alterado pelos dispositivos móveis digitais e todo o processo de transformação acarretado a partir disso. Entre seus últimos trabalhos (BARBOSA; SEIXAS, 2013; BARBOSA, 2009; BARBOSA; TORRES, 2013; BARBOSA; SILVA; NOGUEIRA; ALMEIDA, 2013; BARBOSA; PALACIOS; FIRMINO; CUNHA, 2014) estão citados termos como: ciberjornalismo, jornalismo digital, jornalismo convergente, jornalismo nas redes digitais, jornalismo para dispositivos móveis e jornalismo móvel. Esse último, jornalismo móvel, ganhou espaço entre os autores e pesquisadores em função justamente da popularização de smartphones e tablets, e do aumento na utilização desses artefatos, que já figuram entre as principais fontes de consumo de informação mundial. Firmino (2015) é um dos autores que pesquisa o jornalismo móvel e o define levando em consideração as transformações que este novo aspecto causa na produção do conteúdo jornalístico.

Definimos, assim, na perspectiva da produção, o jornalismo móvel como a utilização de tecnologias móveis digitais e de conexões de redes sem fio pelo repórter na prática jornalística contemporânea visando ao desenvolvimento das etapas de apuração, produção e distribuição de conteúdos do campo ou de transmissão ao vivo (FIRMINO, 2015, p. 11).

Camargo (2015) desenvolve a proposta de terminologia "jornalismo em mobilidade”. Segundo a autora, o jornalismo em mobilidade pode ser considerado o ti po de produção realizada com dispositivos móveis digitais e que contém estratégias já personalizadas para esses dispositivos, levando em conta as características de predominância desses artefatos na atualidade. No entanto, utilizarmos apenas móvel ou em mobilidade para definir a produção e o consumo de conteúdo dentro dos espaços híbridos a partir desses dispositivos é limitante, na medida em que a mobilidade, por si só, já existia em outros produtos jornalísticos. No âmbito dos meios de comunicação, o rádio à pilha e o jornal impresso, por exemplo, eram móveis, podendo ser levados a diversos lugares para o consumo de informação. No âmbito da produção, o fazer jornalístico também é móvel quando se usam blocos de papel e câmeras fotográficas portáteis.

A mudança atual consiste na mobilidade aliada à conexão ubíqua e contínua do leitor e em todas as transformações que o hibridismo dos espaços gera nas relações de 
leitura, interação, produção, distribuição e localização de conteúdo. Lemos (2009) afirma que apesar de estarmos presenciando uma "ampliação da compressão espaçotemporal onde comunicação, mobilidade informacional e deslocamento de pessoas ao redor do mundo são correlatos e se ampliam, a cultura da mobilidade faz parte da evolução da cultura humana como um todo" (p. 29).

Logo, o que há de diferente na mobilidade da contemporaneidade é a capacidade de produção e redistribuição do conteúdo consumido em movimento. Adicionamos rapidez, unimos diferentes funções num único dispositivo e acrescentamos conexão à internet, tanto para jornalistas quanto para o público. "Com as novas mídias móveis digitais, ampliam-se as possibilidades de consumir, produzir e distribuir informação, fazendo com que esta se exerça e ganhe força a partir da mobilidade física" (LEMOS, 2009, p. 30).

Jensen (2013) explica que a mídia e as práticas comunicativas já são móveis há muito tempo, o diferencial dos telefones celulares e outros artefatos de tecnologia digital móvel é a possibilidade de construir interações significativas dentro de uma nova e ampla gama de contextos. Ou seja, é a possibilidade de interagir aliando espaços físicos e digitais, rompendo as barreiras de tempo e espaço, ampliando o alcance das ações e fazendo tudo isso em diversos contextos em conexão ubíqua e permanente.

\begin{abstract}
O que é novo no que chamamos de mídia móvel é a escala e o escopo da integração da comunicação nas práticas cotidianas em formatos crescentemente síncronos, localizados e individualizados. O que é o móvel na comunicação móvel não é apenas o dispositivo em particular, o usuário individual ou a tecnologia em geral, mas os contextos sociais nos quais esses componentes se unem em comunicação (JENSEN, 2013, p. 27) ${ }^{41}$.
\end{abstract}

Lemos (2009) fala numa mobilidade de "pessoas, objetos, tecnologias e informação sem precedentes”. Para ele, essa nova mobilidade impacta também o lugar e o espaço físico onde ela ocorre e vice-versa, produzindo diversos sentidos e interações no processo. Nos meios de comunicação tradicionais, segundo o autor, a mobilidade informacional ocorre somente na esfera do consumo, no entanto, no que ele chama de

\footnotetext{
41 Tradução da autora, trecho original: "What's new about so-called mobile media is the scale and scope of their integration of communication into everyday practices in increasingly synchronous, localized, and individualized formats. What's mobile about mobile communication is not so much the particular device, the individual user, or the general technology, but the social contexts in which these components come together in communication."
} 
“mídias pós-massivas",42, a mobilidade está presente nas esferas do consumo, produção e distribuição, além disso, ela conecta fortemente as instâncias física e digital.

Aguado e Martinez (2008b) afirmam que tomar móvel simplesmente por algo que está deslocado no tempo e espaço é insuficiente para dar conta do que estamos falando nesse contexto atual. Embora não sugiram uma nova denominação para o conjunto de propriedade que faz parte da produção e consumo de conteúdo na atualidade, os autores afirmam que é preciso reforçar as principais características do uso desses dispositivos: ubiquidade, conectividade contínua e demanda, e funcionalidade sensível ao contexto do usuário.

Para além da mobilidade, precisamos também considerar a ubiquidade da conexão e dos artefatos de tecnologia digital móvel. Já em 1991, Mark Weiser então coordenador do Laboratório de Ciência da Computação no Centro de Pesquisa da Xerox (PARC), em Palo Alto, Estados Unidos, afirmava que tanto hardware quanto software se tornariam tão ubíquos que não notaríamos mais suas presenças. O pesquisador alega que as tecnologias mais fundamentais são aquelas que desaparecem, no mesmo sentido que mencionamos anteriormente a defesa de Shappiro (1998) sobre o desaparecimento do ciberespaço. Desaparecer é tornar-se indistinto, uma extensão do nosso corpo, como defenderia Marshall McLuhan. "[...] toda tecnologia gradualmente cria um ambiente humano totalmente novo. Os ambientes não são envoltórios passivos, mas processos ativos" (MCLUHAN, 1969, p. 10).

McLuhan (1969) propôs compreendermos os meios de comunicação enquanto extensões do homem, do nosso corpo. Se na época em que conduziu seus estudos es sa visão já era clara, se estivesse vivo hoje, o autor veria uma consolidação ainda mais enfática de suas ideias. Para ele, toda extensão altera os sentidos e os comportamentos dos sujeitos, logo, se os meios são extensões, esses são capazes de engendrar relações sensoriais diferentes e novos equilíbrios dentro do processo comunicacional. Na medida em que o dispositivo móvel digital é completamente diferente do que se tinha enquanto

\footnotetext{
42 Lemos (2007a) considera que as cidades se transformam na atualidade diante das interferências provocadas pela ascensão da tecnologia digital móvel. O autor apresenta o termo cibercidade para falar da cidade onde a urbanidade é constituída pela interação entre mídias de função massiva e pós-massiva. Mídias de função massiva são aquelas coordenadas pela lógica da mídia de massa, onde há um fluxo centralizado e verticalizado de informação. As mídias de função pós-massiva são aquelas onde o fluxo informativo é horizontalizado e distribuído, havendo uma liberação do pólo de emissão a partir de ferramentas comunicacionais de fácil uso e acesso, potencializadas pela tecnologia digital e sua popularização. Importante ressaltar que o conceito está ligado à função e não ao dispositivo, ou seja, plataformas digitais podem ter funções massivas e produtos analógicos podem ter funções não-massivas.
} 
artefato móvel anteriormente, é natural que precisemos considerar os novos processos, camadas, engendramentos e potencialidades na equação comunicacional.

Pereira (2011), ao explicar McLuhan, esclarece mais esse aspecto ilustrando que as extensões do sistema humano são capazes de transformar "radical e permanentemente" o próprio sistema no qual elas se inserem. Segundo o autor, as extensões do sistema humano têm um caráter artificial, no sentido de que são invenções não previstas inicialmente em nosso código genético, por exemplo; sendo assim, essa inovação engendra novos hábitos e comportamentos, transformando o próprio sistema e os atores envolvidos nele. Para McLuhan, as extensões tecnológicas são meios e, como sabemos, “o meio é a mensagem”. “[...] 'o meio é a mensagem', porque é o meio que configura e controla a proporção e a forma das ações e associações humanas" (MCLUHAN, 1969, p. 23). Logo, podemos afirmar que o smartphone é ativo no engendramento de novos comportamentos e configuração de novas ações no consumo de conteúdo jornalístico.

Weiser (1991) usa o termo "virtualidade corporificada" para se referir a um futuro onde os computadores pessoais estarão completamente integrados ao dia a dia das pessoas. Se considerarmos as possibilidades apresentadas pela internet das coisas, o futuro visualizado por Weiser fica bastante claro já nessa época, em função da onipresença da conexão à internet e também do contato constante com os dispositivos móveis desde o momento em que acordamos até o final do dia. "Eu e meus colegas do PARC acreditamos que o que chamamos de computação ubíqua irá, gradualmente, emergir como o modo dominante de acesso a computadores nos próximos 20 anos" (p. 104).

De acordo com Araujo (2003), referir-se à computação ubíqua tem como princípio básico o significado de mover-se além dos computadores pessoais e tornar-se pervasivo no cotidiano dos usuários. A palavra pervasivo não existe no português, seu uso na bibliografia brasileira vem da tradução da palavra "pervasive", que em inglês significa dominante, disseminado, abrangente, generalizado. Alguns pontos são fundamentais quando se fala de computação ubíqua: o conteúdo pode ser acessado por múltiplos dispositivos e fica permanentemente disponível ao usuário, independentemente de local e hora; os dispositivos são capazes de interagir entre si, com ou sem mediação humana; cada dispositivo possui um formato específico e é capaz de trocar informações com o ambiente externo. 
Assim como há diferenças entre os termos criados para indicar diferentes tipos de jornalismo também há diferença quando nos referimos à computação ubíqua, móvel e pervasiva. Segundo Araujo, a computação móvel indica somente a capacidade de mover os sistemas computacionais com o usuário, no entanto, nesse caso, o dispositivo não é capaz de obter informações sobre o contexto do usuário, ou seja, o dispositivo não atua nem como um sensor nem em parceria com sensores. A computação pervasiva aponta para uma ideia mais próxima do significado da própria palavra, isto é, para um tipo de computação que está tão generalizada no ambiente que já não se percebe a sua existência. É o caso, por exemplo, de dispositivos da internet das coisas e inteligência artificial que controlam o funcionamento de uma casa. Já na computação ubíqua há uma união dos preceitos da computação móvel e da pervasiva, integrando mobilidade e abrangência, pressupondo que os dispositivos além de móveis, estão permanentemente conectados, sendo capazes de agir como e com sensores, trocando informações com o ambiente externo e agindo sem mediação humana.

A autora identifica ainda três princípios da computação ubíqua: diversidade, descentralização e conectividade. Diversidade indica que o dispositivo atende múltiplos e diferentes propósitos do usuário, muitas vezes acumulando potencialidades de diferentes artefatos. Descentralização quer dizer que os serviços são realizados por múltiplos dispositivos que interagem entre si e com o ambiente, por exemplo, smartphones que interagem com satélites e bancos de dados em servidores. Conectividade, como o próprio termo indica, é a conexão permanente e independente de local e hora.

Embora a ideia de ubiquidade que utilizamos aqui derive da ideia de computação ubíqua, o próprio significado e etimologia da palavra já são suficientes para nos dar a noção do que queremos indicar ao afirmar que o contexto em que estamos inseridos, atualmente, é um contexto de conexão e mobilidade ubíquas. O termo ubiquidade vem do latim, ubique+idade, onde $u b i=$ onde e que $=$ sufixo generalizador, e ubique significa "em todas as partes", estando dentro da mesma família de ubíquo, "que está ou parece estar em todas as partes ao mesmo tempo" (SILVA, 1985). No dicionário de português Michaelis ${ }^{43}$, o significado de ubiquidade consta como: 1) Qualidade do que está ou existe em todos ou em praticamente todos os lugares; 2) Caráter ou propriedade de um ser que dá a impressão de estar presente em vários lugares ao mesmo tempo. No

\footnotetext{
${ }^{43} \mathrm{http}: / /$ michaelis.uol.com.br/
} 
mesmo dicionário, ubíquo, do latim ubiquus, consta como onipresente, ou que está por toda parte ao mesmo tempo.

Pavlik (2014) ressalta que dentro do significado de ubiquidade é importante considerar a presença simultânea, o que, no contexto comunicacional, implica que qualquer pessoa, em qualquer lugar tenha acesso a uma rede de comunicação, não apenas acessando, mas também produzindo conteúdo. $\mathrm{O}$ autor explica que se quando do surgimento da internet já falávamos sobre a possibilidade de ampliação do poder de atuação do jornalismo, que antes não podia estar em todo lugar, mas agora, com auxílio do público poderia, com smartphones essa realidade é ainda mais potencializada.

Os artefatos miniaturizados e conectados facilitam a ideia "McLuhaniana" de aldeia global. Essa é uma das consequências da ubiquidade para o jornalismo, segundo Pavlik: o fortalecimento do conteúdo produzido pelo público. A segunda consequência seria o crescimento de narrativas geolocalizadas e imersivas, com uso de realidade aumentada $^{44}$ e realidade virtual, e a terceira, o uso do big data em favor do jornalismo de dados.

\begin{abstract}
Na próxima década, conteúdos ubíquos geolocalizados em mídias móveis e dispositivos adaptados ao corpo provavelmente conduzirão a uma nova forma de jornalismo sem as barreiras impostas pelas tradicionais plataformas de apresentação de notícias. Em vez disso, os cidadãos usarão seus telemóveis ou os wearables para acessar ou contribuir com o conteúdo noticioso geolocalizado em qualquer lugar de cada comunidade. Os cidadãos irão se envolver em narrativas imersivas e interativas como se estivessem em uma máquina do tempo virtual enquanto percorrem suas comunidades. Estas narrativas imersivas fornecerão um contexto geográfico ainda mais rico do que aquele possível na mídia tradicional. $\mathrm{O}$ acesso a estas narrativas imersivas poderá ser feito remotamente, bem como por meio da realidade virtual. Imersão virtual em tempo real também se tornará amplamente disponível, assim que repórteres, sejam eles profissionais ou cidadãos, gerem narrativas ao passar por suas comunidades e compartilhar seus vídeos ou outros conteúdos gerados automaticamente via múltiplos sensores. Será possível contar virtualmente qualquer estória neste modelo, por meio de sensores que capturam fotos, vídeo ou outras informações do ambiente, como dados sobre poluição, como a qualidade do ar, sons e outros inputs (PAVLIK, 2014, p. 176).
\end{abstract}

Okazaki e Mendez (2013) realizaram um amplo estudo acerca do conceito de ubiquidade e do seu uso no campo da comunicação. Após uma seleção de artigos e

\footnotetext{
44 Segundo Santos (2015), a realidade aumentada "baseia-se na possibilidade de associação de algum tipo de conteúdo multimídia adicional (fotos, vídeo, animações, objetos tridimensionais ou áudio) a uma imagem ou padrão visual previamente determinado, em alguns casos associado a informações de geolocalização" (p. 112). Já na realidade virtual, o ambiente é gerado totalmente pelo computador e prevalece sobre qualquer outro, pois o usuário está imerso neste diferente local criado pela máquina.
} 
trabalhos que referenciam e definem ubiquidade, os autores puderam estabelecer que, dentro da amostra, o termo é utilizado de forma unânime como sinônimo de onipresença e generalização, no sentido de estar presente a todo o momento e não ser fisicamente perceptível pelos usuários. Além disso, a maioria dos usos também coloca a ubiquidade enquanto um dos principais atributos dos sistemas móveis. Okazaki e Mendez propõem quatro dimensões através das quais os usuários experimentam a ubiquidade nos dispositivos móveis digitais: 1) Continuidade e simultaneidade; 2) Rapidez e imediatismo; 3) Portabilidade e mobilidade; e, 4) Busca e alcance.

Continuidade se refere à conexão permanente e irrestrita, e simultaneidade está relacionada à possibilidade de realizar múltiplas e diferentes tarefas ao mesmo tempo. Rapidez, obviamente, se refere ao fato de a conexão não apenas ser rápida, mas tornar toda uma série de atividades e interações cotidianas muito mais rápidas também. $\mathrm{O}$ imediatismo implica na possibilidade de realizar essas atividades de forma fácil e sem esforço. Portabilidade é a característica de ser leve e portátil o suficiente para ser levado a qualquer lugar e a mobilidade está relacionada ao fato de poder ser operado em movimento, em trânsito entre lugares.

Por último, busca e alcance estão traduzidos livremente aqui nes ses termos, mas são colocados no trabalho original como "searchability" e "reachability" que poderiam ser compreendidos como a capacidade do dispositivo de encontrar e ser encontrado, alcançar e ser alcançado. Segundo os autores, esses aspectos estão relacionados à capacidade de realização de um exame minucioso nos sinais enviados e recebidos pelo dispositivo. Ou seja, isso está relacionado à capacidade de compreender dos dispositivos móveis digitais não somente enquanto objetos de consumo, mas também enquanto sensores e fontes de informação para um sistema complexo composto por outros dispositivos e sensores. Há um caráter de dupla direção na ação, por exemplo, de smartphones. Ao mesmo tempo em que ele serve como uma interface para o consumo de conteúdo e interação com outros usuários, ele também atua como um agente não humano dentro de uma rede sem mediação humana, onde sinais sobre localização, uso, consumo, tempo, entre outros, estão sendo enviados para uma série de servidores e outros dispositivos separados geograficamente.

As pessoas cada vez mais portam mais sensores que incorporam e emitem informação de maneira contínua. O celular é um dos principais, já que só com o que ele processa se poderia saber onde estamos, o nível de atividade que 
desempenhamos, ou, cada vez mais coisas sobre o que fazemos (TASCÓN; COULLAUT, 2016, p. 108) $)^{45}$.

Os dispositivos móveis ubíquos são, ao mesmo tempo, dispositivos de consumo pelo usuário e de percepção por outros dispositivos e usuários. Essa característica já estava presente em computadores pessoais e até mesmo em televisores (se pensarmos que institutos de medição são capazes de saber quantos aparelhos estão ligados e em qual canal em determinado momento), mas ganha uma potencialização quando falamos de smartphones, na medida em que a quantidade de dados que pode ser capturada e o tipo de dado se diferenciam, criando novos sistemas e contextos de comunicação.

Sendo assim, acreditamos que a dimensão tomada pelos dispositivos de tecnologia digital móvel na vida dos consumidores e a consequente transformação causada nos processos de produção, consumo e distribuição de conteúdo torna necessária a visualização do jornalismo para além de somente a mobilidade, tomada em seu conceito tradicional, pois essa já não é mais a mesma presente no rádio de pilha ou no jornal impresso. Nossa hipótese (H1 deste trabalho) é que estamos num movimento de ubiquidade do consumo de informação, fomentado, principalmente, por esse fortalecimento dos dispositivos móveis, da internet das coisas e dos espaços híbridos de comunicação. Como dissemos, este contexto altera as instâncias de produção, consumo e distribuição de informação jornalística, fazendo com que seja necessário pensar o jornalismo de forma diferente, dando conta de todos esses novos elementos.

Com isso, optamos, neste trabalho, pela adoção do conceito de jornalismo ubíquo proposto por Salaverría (2016a). O autor apresenta o conceito como o jornalismo "que estará ao alcance das pessoas em todo momento e lugar, e se adaptará automaticamente a seus interesses e necessidades". Para o pesquisador, o jornalismo móvel é uma antecipação do jornalismo ubíquo, no entanto, esse último ultrapassará as limitações do anterior e a relação entre conteúdo e usuários não será apenas de consulta, mas sim personalizada, oferecendo possibilidades precisas aos interesses e ao contexto pessoal.

Neste jornalismo onipresente, que se distingue pouco a pouco graças aos múltiplos sensores e telas que nos rodeiam, a informação sai ao encontro dos

\footnotetext{
45 Tradução da autora, trecho original: "Las personas cada vez portamos más sensores que incorporan y emiten información de manera continua. El móvil es uno de los principales, ya que solo con lo que él procesa se podría saber dónde estamos, el nivel de actividad que tenemos o, cada vez, más cosas de las que hacemos.
} 
usuários, poupando o esforço de busca-la. Por isso é algo mais do que um simples jornalismo móvel. Não se trata apenas de o usuário ter consigo um dispositivo a partir do qual possa consultar periodicamente a informação; na realidade, o jornalismo ubíquo proporciona uma oferta informativa personalizada e ininterrupta, que se mostra sem a necessidade de que cada usuário a solicite, através das telas que sucessivamente aparecem em seu caminho (em casa, no trabalho, num veículo de transporte, em um hotel...). [...] Os últimos avanços no âmbito da domótica e da internet das coisas apontam exatamente nessa direção: tanto o consumo como a produção de conteúdos jornalísticos se realizará num sistema interconectado de dispositivos que permitirá uma comunicação cada vez mais corpórea com a informação através da voz, dos gestos, do movimento dos olhos ou, quem sabe, pelo poder da mente - (SALAVERRÍA, 2016a, p. 259 e 260 $)^{46}$.

Como podemos perceber, o conceito de jornalismo ubíquo, proposto pelo autor, é mais amplo e complexo do que vemos aplicado, em geral, nos produtos jornalísticos existentes até o momento para dispositivos móveis. O próprio autor problematiza essa questão dizendo que a resposta dos veículos às transformações possibilitadas pela tecnologia tem sido pequena. Alguns exemplos existentes são adaptações nos sites para tornarem-se responsivos ${ }^{47}$, aplicativos criados em linguagem HTML5 ${ }^{48}$ e notificações por push, no entanto, essas possibilidades ainda estão distantes do potencial completo possibilitado por esses artefatos. "Pode-se dizer que, mais que elaborar publicações para dispositivos móveis, [as empresas] têm se contentado com re-empacotar suas publicações web. Esta forma de explorar a relação entre jornalismo e dispositivos móveis é insuficiente" (SALAVERRÍA, 2016a, p. 258-259) ${ }^{49}$.

Para o autor, os dispositivos funcionam como auxiliares na hora de produzir jornalismo, alterando e transformando as rotinas de produção. No entanto, apesar de

\footnotetext{
${ }^{46}$ Tradução da autora, trecho original: "En este periodismo omnipresente, que descuella poco a poco gracias a los múltiples sensores y pantallas que nos rodean, la información sale al encuentro de los usuarios, ahorrándoles el esfuerzo de buscarla. Por eso es algo más que un simple periodismo móvil. No se trata apenas de que el usuario porte consigo un dispositivo desde el que consultar periódicamente la información; en realidad, el periodismo ubicuo proporciona una oferta informativa personalizada e ininterrumpida, que se muestra sin necesidad de que cada usuario la solicite allá donde esté, a través de las pantallas que sucesivamente le salen al encuentro (en casa, en el lugar de trabajo, en un vehículo de transporte, en un hotel...). [...] Los múltiples avances actuales en el ámbito de la domótica y en la llamada internet de las cosas apuntan exactamente en esa dirección: tanto el consume como la producción de contenidos periodísticos se realizará en un sistema interconectado de dispositivos, que permitirán una comunicación cada vez más corpórea con la información - a través de la voz, los gestos, el movimiento de los ojos o, quién sabe, incluso por vía directa desde la mente -."

${ }^{47}$ Sites responsivos são aqueles que se adaptam a qualquer tamanho de tela.

${ }^{48}$ HTML 5 indica a quinta versão da linguagem de programação para web, HTML. Este tipo de código permite estruturação e apresentação do conteúdo em formatos mais amigáveis e com possibilidades que antes estavam atreladas a outros tipos de linguagem já em desuso. Sua vantagem é ser capaz de criar interfaces leves e multimídia.

${ }^{49}$ Tradução da autora, trecho original: "Es decir, más que elaborar publicaciones para móviles, se han contentado con reempaquetar sus publicaciones web. Esta forma de explorar la relación entre periodismo y móviles resulta, a la vista está, insuficiente".
} 
fazerem um uso considerável desses artefatos na esfera da produção, as empresas ainda pecam nas instâncias de distribuição e consumo, na medida em que essas extrapolam o limite do dispositivo móvel e envolvem toda a estrutura, cultura e estratégia da empresa. Entre as possibilidades pouco ou nada aproveitadas pelas empresas nessa área, Salaverría (2016a) cita como exemplos a geolocalização, os dispositivos vestíveis, tradutores automáticos, drones, algoritmos, web semântica e realidade aumentada. Além disso, a própria funcionalidade do dispositivo enquanto um sensor, uma fonte de informação sobre o usuário, também não parece estar sendo levada em consideração pelas empresas.

O desenvolvimento tecnológico cria possibilidades de produção, distribuição e consumo de conteúdos inéditas, como, por exemplo, os produtos que fazem parte da noção de internet das coisas. Usar o termo internet das coisas significa remeter-se a dispositivos conectados que fazem parte do dia a dia do usuário na maior parte dos seus contextos de existência. Por exemplo, é possível automatizar diversos serviços de uma casa, como acendimento de luzes, geladeira, aparelho de som, televisão, máquina de lavar, eletroeletrônicos em geral, tudo isso sendo controlado à distância, conectado à internet, e ainda, com possibilidade de personalização aos hábitos do usuário a partir do uso de inteligência artificial. A Amazon lançou em 2015 a caixa de som Amazon Echo que funciona como um assistente pessoal que responde a comandos de voz, normalmente iniciados pela palavra Alexa, nome dado à voz que interage com o interlocutor. Ao dizer "Alexa, give me the news" ("Alexa, me dê as notícias"), a assistente oferece ao usuário uma seleção de notícias e reportagens capturada a partir dos principais players de conteúdo do mercado. O Google também lançou em 2016 um assistente pessoal, o Google Home, bastante semelhante em formato e funcionamento ao da Amazon, sendo igualmente capaz de oferecer ao usuário um resumo das principais notícias do dia. Além disso, carros, smartwatches (relógios inteligentes) já são uma forte realidade do mercado, podendo somar-se ainda a óculos que venham a ser comercializados, num formato que se assemelhe ao Google Glass. Todos esses dispositivos são também sensores, ou seja, captam informações dos usuários. À parte da discussão sobre a segurança e a privacidade desses dados, um uso importante e útil, se feito eticamente, é a personalização de serviços para leitores e consumidores, a partir do conhecimento de seus hábitos e contextos de interação com o dispositivo móvel digital. 
Salaverría (2015) aponta que o futuro próximo é composto por um vasto repertório de dispositivos que permitem que a informação se conecte ao usuário em qualquer lugar e contexto. Isso, no entanto, não significa que estejamos visualizando uma indústria jornalística preparada para enfrentar esse tipo de cenário, na medida em que nem mesmo os produtos oferecidos para dispositivos móveis demonstram um aproveitamento das possibilidades existentes. Tascón e Coullaut (2016) também reforçam essa preocupação ao descreverem a importância da compreensão e do uso apropriado do Big Data $^{50}$ na atualidade, principalmente pelas empresas jornalísticas. “Até agora, muitos têm optado por aplicar o mesmo modelo de negócio para a impressão do jornal em papel e para as edições na web, inclusive o modelo da rede se adapta tal qual para as novas edições em tablets. Este enfoque funcionará com o Big Data?" (TASCÓN; COULLAUT, 2016, p. 51) ${ }^{51}$.

Durante a predominância dos veículos de comunicação de massa como televisão e jornal impresso, era comum que as empresas jornalísticas soubessem pouco ou quase nada sobre seus consumidores. A maioria dos dados que estavam disponíveis sobre o público vinha de pesquisas feitas com assinantes e com o público em geral por um instituto de pesquisa, o que encarecia o processo e o tornava esporádico. Em comparação com esse momento anterior, a realidade vivida atualmente é muito mais favorável, no sentido de permitir ao veículo que conheça os seus leitores. Uma grande quantidade de dados sobre o público se torna facilmente disponível a partir do momento em que os jornais solicitam cadastros de seus usuários. Além disso, quando o cadastro é feito a partir de um serviço de rede social online os dados podem ser mais amplos e pessoais. Numa esfera ainda mais ampla, a partir do aplicativo móvel é possível obter informações do usuário como localização, trajetos comuns, conteúdos mais acessados, interesses, tudo podendo ser realizado com permissão a partir da autorização do leitor.

Um dos desafios do Big Data aplicado aos meios de comunicação é oferecer às pessoas informação especificamente desenhada para elas. [...] Analisando o consumo de informação e como este se engendra, se podem realizar modelos

\footnotetext{
50 O desenvolvimento tecnológico fez com que muitos dados e informações fossem gerados numa velocidade e volume muito maiores do que ocorria antes do surgimento dos computadores. O nascimento destas máquinas fez com que se pudesse armazenar mais dados e contabilizá-los mais rapidamente. Com a Internet, a quantidade de informações armazenadas e também em circulação tomou proporções ainda maiores. Segundo Tascón e Coullaut (2016), essas "bases de dados gigantes às quais podemos acessar e trabalhar com" confiram o chamado Big Data.

${ }^{51}$ Tradução da autora, trecho original: "Hasta ahora, muchos han optado por aplicar el mismo modelo de negocio para la impresión del periódico en papel y para sus ediciones en la web, incluso el modelo de la Red se adapta tal cual a las nuevas ediciones en tableta. ¿Funcionará este enfoque con el Big Data?”
} 
preditivos que melhorem os produtos e a experiência dos leitores (TASCÓN; COULLAUT, 2016, p. 51-52) ${ }^{52}$.

Salaverría (2016c) acrescenta que a internet das coisas expande a rede atual, na medida em que a conexão alcança todo tipo de objeto cotidiano e esses não são apenas emissores de informação, como já comentamos, mas sensores capazes de emitir também dados sobre o próprio sistema e o usuário. Segundo o pesquisador, o tratamento correto e coordenado desses dados permite extrair padrões de uso dos sujeitos e, a partir daí, inferir gostos, preferências e contexto do usuário.

Há um novo ecossistema digital em vigência e o jornalismo não poderá operar dentro desse novo sistema a partir das mesmas regras com que operava no século XX. Todo um conjunto de comunicação de massa se transformou e afetou profundamente as esferas de consumo de conteúdo em geral. Berghella (2015) diz que a rede se converteu num grande sistema formado por aplicativos e plataformas digitais que oferecem ao público uma capacidade potencializada de interação e poder de decisão. Segundo ela, há uma nova dinâmica entre usuários e conteúdos, e isso transforma o modo como o jornalismo deve distribuir o resultado do seu trabalho.

Construir conteúdos para dispositivos móveis digitais e distribuí-los ao público não é simplesmente tornar menor o texto e mais rápido o carregamento da tela. $\mathrm{A}$ experiência não é simplesmente menor, em função da tela menor, a experiência de consumo é outra, completamente diferente e transformada do que se conhecida anteriormente. O produto do jornalismo ubíquo não é simplesmente uma versão menor daquele para o desktop, mas sim aquele que se adapta aos contextos de vida e consumo do usuário que está imerso em condições de mobilidade, portabilidade e ubiquidade. "Recordemos também que uma parte de nossa audiência são os millenials, a geração que hoje tem entre 18 e 35 anos, que busca informação imediata, explicativa, aberta à participação, audiovisual e presente em telefones móveis e redes sociais, principalmente" (IRIARTE, 2015, p. 148) ${ }^{53}$.

\footnotetext{
52 Tradução da autora, trecho original: "Uno de los retos del Big Data aplicado en los medios de comunicación es ofrecer a las personas información específicamente diseñada para ellos. [...] Analizando el consume de información y cómo este se produce, se pueden realizar modelos predictivos que mejoren los productos y la experiencia de los lectores."

${ }^{53}$ Tradução da autora, trecho original: "Recordemos además que una gran parte de nuestra audiencia son los millenials, la generación que hoy tiene entre 18 y 35 años, que busca información inmediata, explicativa, abierta a la participación, audiovisual y presente en teléfonos móviles y redes sociales, principalmente."
} 
Neste sentido, o jornalismo permanece tendo na sua essência obviamente os fundamentais preceitos da profissão, da ética e da busca pela informação, no entanto, o espectro de ação mudou e se ampliou, na medida em que a produção e os formatos de distribuição já não podem ser os mesmos. O profissional ganha novas e diferentes competências, os veículos também e os produtos se renovam e se adaptam. Por isso buscamos apresentar o jornalismo ubíquo como aquele que dá conta dos novos elementos que entram em questão nessa equação. Iriarte (2015) elenca alguns exemplos do que as redações deveriam adotar como comportamentos para o jornalismo atual: métricas e medição de tráfego adequado, reuniões de pauta com prioridade ao conteúdo móvel, coberturas ao vivo idealizadas para dispositivos móveis digitais, atualização $24 \times 7$, publicadores simples e adaptados às potencialidades de smartphones, conteúdo exclusivo para aplicativos de redes sociais online e uso de metadados.

Ao apresentarmos esta proposta de jornalismo ubíquo podem surgir questionamentos quanto a uma possível "codependência" dos dispositivos móveis digitais. Ou seja, o jornalismo ubíquo só existe em artefatos como smartphones e tablets? Sim e não. Para Aguado, Feijoó e Martínez (2013), o entorno móvel se “encarna" na atualidade em smartphones e tablets, mas isso não exclui que outras tecnologias futuras - e algumas até já presentes - adentrem na mesma concepção. Um exemplo disso são os wearables, os carros conectados e os dispositivos ligados à internet das coisas.

\begin{abstract}
A natureza híbrida da tecnologia resulta neste ponto em condição necessária dessa indefinição líquida: o meio móvel não são os dispositivos móveis ou, ao menos, não somente os que conhecemos até esta data. O entorno móvel é, em essência, um entorno multidispositivo, cujo núcleo reside em uma concepção de modo de consumo e acesso ao conteúdo e aos serviços [...] (AGUADO; FEIJOÓ; MARTÍNEZ, 2013, p. 18) ${ }^{54}$.
\end{abstract}

Para Tascón e Coullaut (2016), a internet das coisas é o ecossistema onde o Big Data é processado, sendo que esse ecossistema é formado por todo tipo de dispositivos e sensores que são capazes de executar ações e interagirem de forma independente da ação humana. Esses sensores nos acompanham diariamente, principalmente na figura do celular, mas não apenas. Segundo os autores, a própria roupa que vestimos está

\footnotetext{
${ }^{54}$ Tradução da autora, trecho original: "La naturaleza híbrida de la tecnología resulta en este ponto condición necesaria de esa indefinición líquida: el medio móvil no son los dispositivos móviles o, al menos, no sólo los que conocemos hasta la fecha. El entorno móvil es, en esencia, un entorno multidispositivo, cuyo núcleo reside en una concepción del modo de consumo y acceso al contenido y a los servicios [...]"
} 
começando a incorporar sensores que são capazes de oferecer informações como os índices de contaminação do ar do local onde o usuário está.

Os pesquisadores esclarecem que o termo internet das coisas foi criado pelo engenheiro Kevin Ashton, em 1999, quando tratava da tecnologia RFID (Radio Frequency Identification Device), pela qual é possível "reconhecer de forma automática qualquer objeto" que possua uma etiqueta de radiofrequência, e suas potencialidades quando se liga à internet. Para Tascón e Coullaut, a tecnologia RFID é o princípio das transformações que estão sendo e ainda serão geradas pela internet das coisas. "Somos dados - objetos, animais e pessoas - conectados" (p. 109) ${ }^{55}$.

A partir disso, é possível compreender que o jornalismo ubíquo é uma proposta que envolve um contexto de transformação midiática dentro do espaço híbrido no qual vivemos hoje. $\mathrm{Na}$ atualidade, essa proposta é profundamente evidente nos dispositivos móveis digitais mais avançados tecnologicamente, mas isso não significa que o conceito não possa abarcar outros e novos artefatos em seguida, além dos equipamentos já tradicionais e conhecidos como computadores pessoais. A fim de que possamos compreender melhor as características do jornalismo ubíquo, apresentamos a seguir um apanhado das características que compõem o conceito e que puderam ser agrupadas até este momento.

\subsection{Propriedades do jornalismo ubíquo}

Especificamente neste trabalho, por limitação temporal e física, estamos tratando mais a fundo e detalhadamente das mudanças nos formatos dos produtos jornalísticos, entretanto, o conceito abarca também outras mudanças como, por exemplo, nos perfis dos profissionais, das empresas e do público consumidor de conteúdo jornalístico, além do modelo de negócio e das estratégias das marcas jornalísticas. Essas últimas estão contempladas dentro das categorias aqui expostas e também nas entrevistas realizadas no trabalho de campo da pesquisa, apresentadas nas análises, no entanto, não são o foco principal desta investigação, por isso, não estão rigorosamente aprofundadas.

A fim de que possamos dar um panorama maior da amplitude do conceito de jornalismo ubíquo antes de nos debruçarmos sobre as mudanças específicas nos

\footnotetext{
${ }^{55}$ Tradução da autora, trecho original: "Somos datos -objetos, animales y personas- conectados".
} 
formatos da narrativa digital, apresentamos a seguir um conjunto de 13 propriedades que fazem parte deste conceito. A seleção foi realizada a partir da revisão bibliográfica do estado da arte dos estudos em jornalismo, mobilidade e ubiquidade com suas respectivas transformações ao longo dos anos, unindo propostas de vários e diferentes autores (BARBOSA, 2007, 2013; PALACIOS; BARBOSA; FIRMINO; CUNHA, 2014; BERTOCCHI, 2014; JENSEN, 2013; ARAUJO, 2003; PAVLIK, 2014; OKAZAKI; MENDEZ, 2013; SALAVERRÍA, 2016a, 2016b, 2016c; MIELNICZUK, 2001, 2003; SOUZA e SILVA, 2006; LEMOS, 2009; TASCÓN; COULLAUT, 2016).

\section{- Espaço híbrido}

De acordo com o conceito proposto por Souza e Silva (2006), vivemos na atualidade, em um espaço híbrido onde os dispositivos possuem interfaces sociais capazes de afetar e transformar a maneira como as pessoas interagem e circulam cotidianamente. O jornalismo ubíquo está inserido nesse contexto e nesse tipo de “interface social”, o que quer dizer que seus produtos são capazes de afetar o comportamento dos usuários em trânsito pela cidade, além de também poder interagir com o contexto no qual os usuários estão inseridos. Sendo assim, consideramos o jornalismo ubíquo como "invisível” no espaço híbrido, no sentido de que ele está - e estará ainda mais - tão impregnado nas atividades cotidianas dos sujeitos que já não se pode considerar que buscamos a informação num espaço superior ou diferente daquele em que estamos habitando.

\section{- Legado potencializado}

O jornalismo ubíquo congrega e potencializa as características do webjornalismo, ou seja, elas também fazem parte do atual contexto da produção jornalística. Mielniczuk (2001) apresenta seis características para o webjornalismo: hipertextualidade, interatividade, multimidialidade, personalização, atualização contínua e memória. Essas, no entanto, aparecem mais desenvolvidas na proposta atual. A característica personalização, na época, era muito pouco explorada pelos sites de notícia e ficou, basicamente, obsoleta até o surgimento dos aplicativos para dispositivos móveis digitais, quando os usuários podem efetivamente decidir 
as editorias que serão visualizadas dentro de um aplicativo jornalístico. Essa evolução transforma também a característica da hipertextualidade. Para Manovich (2001), a interação do usuário ocorre não apenas na possibilidade de escolher o caminho de leitura num conteúdo hipertextual, mas também na opção de escolher quais elementos serão apresentados na tela. Ou seja, o autor conecta a noção de interação com a de link no hipertexto. Além da questão hipertextual, também é possível dizer que a interação entre leitor e veículo jornalístico na rede digital é potencializada, na medida em que é possível interagir mais rapidamente pelo mesmo dispositivo em que se está tendo acesso ao produto, considerando as características próprias e potenciais desse artefato, como agilidade, mobilidade e geolocalização.

\section{- Jornalismo Digital em Base de Dados}

O jornalismo ubíquo também congrega as funcionalidades e categorias do Jornalismo Digital em Base de Dados. Barbosa (2009) apresenta o paradigma enquanto modelo jornalístico que tem as bases de dados como definidoras de sua estrutura e organização, detentor de 18 funcionalidades e sete categorias expressivas $^{56}$. Entre elas estão questões como automatização, densidade informativa, hiperlinkagem e flexibilidade. Todos esses elementos podem ser encontrados no jornalismo ubíquo porquanto esse também está fortemente conectado às bases de dados, ou seja, a base de dados ainda é um componente primordial para o jornalismo (e para basicamente todo serviço disponível via internet) também em sua fase ubíqua.

\section{- Multisuporte}

O jornalismo ubíquo opera a partir da integração de múltiplas plataformas e dispositivos. O conteúdo não circula somente no aplicativo de notícias da empresa jornalística, mas também por redes sociais online, outros aplicativos de terceiros e ainda, vários artefatos como smartphones, tablets, smartwatches,

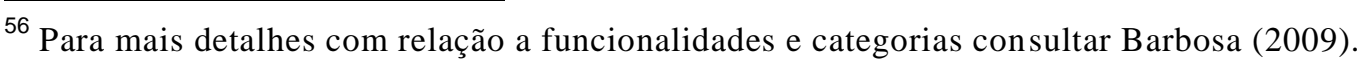


carros conectados, entre outros. Não se trata mais de uma notícia publicada em seu formato tradicional e nele se encerrando, mas de um conjunto híbrido de ambientes e artefatos em relacionamento. Para Salaverría e Avilés (2008), as publicações atuais subaproveitam as possibilidades oferecidas pela evolução tecnológica. "Os conteúdos multimídia que hoje caracterizam as formas mais vanguardistas do jornalismo são, no fundo, uma amálgama de linguagens exploradas durante o século XX pelos meios impressos e audiovisuais" (p. 32$)^{57}$. Segundo os autores, é preciso explorar conteúdos e serviços por múltiplas plataformas, utilizando-se de níveis de complexidade adequados às potencialidades de cada meio.

\section{- Contextualidade}

O jornalismo ubíquo permite que seu conteúdo seja não apenas consumido em trânsito, mas também reprocessado e redistribuído nessas condições. Conforme explicado por Jensen (2013), a mobilidade potencializada existente nos espaços híbridos faz com que as interações possibilitadas pela tecnologia digital ocorram em diferentes contextos geográficos e temporais ao longo de um curto período de tempo e com o mesmo usuário final. Ou seja, múltiplos contextos são enfrentados ao longo do dia e a informação jornalística se adapta a esses diferentes micromomentos. O lugar e o momento assumem novos sentidos para o conteúdo jornalístico na medida em que também assumem novos níveis de importância para o usuário ao longo do dia e do consumo de conteúdo.

\section{- Integração}

Conforme já discutimos aqui, a ubiquidade pressupõe não apenas a mobilidade e a conexão permanente, mas também o "desaparecimento" dos dispositivos com relação à percepção do usuário. Ou seja, os artefatos atuam como extensões de corpo humano e tornam-se plenamente integrados ao uso e consumo do público.

\footnotetext{
57 Tradução livre da autora deste trabalho, trecho original: "Los contenidos multimedia que hoy caracterizan a las formas más vanguardistas del periodismo son, en el fondo, una amalgama de los lenguajes explorados durante el siglo XX por los medios impresos y audiovisuales"
} 
Neste sentido, também o jornalismo ubíquo e a produção de conteúdo acabam tendo essa mesma lógica. O conteúdo integra-se ao cotidiano do usuário e ao dispositivo utilizado para seu consumo. Torna-se natural o recebimento de informações usuais e necessárias como, por exemplo, a previsão do tempo e as principais notícias do dia, no começo da manhã. Igualmente, tornam-se usuais as notificações recebidas no smartphone e essas não demandam, necessariamente, o acesso ao aplicativo de notícias, mas sim, integram-se ao próprio sistema operacional do dispositivo. Pellegrino (2006) afirma que a vida cotidiana está crescentemente mediada pelos artefatos digitais. Num primeiro aspecto, esse "colamento" dos dispositivos em nosso dia a dia tem uma dimensão de naturalização, onde esses se tornam invisíveis à atenção do usuário, com seu uso atrelado completamente à rotina. Num segundo aspecto, está o que a autora chama de ubiquidade da tecnologia, onde esta, além de estar invisível, permanece conectada ao nosso corpo e ao ambiente, "desaparecendo em nossos bolsos e mãos” (p. 135).

\section{- Continuidade}

O jornalismo ubíquo se dá 24 horas por dia, sete dias por semana. Poderia se argumentar que esse também é o andamento do jornalismo impresso ou na web, pois há sempre profissionais que podem ser destacados a qualquer momento para a cobertura de uma notícia. No entanto, o que se quer dizer com permanentemente disponível amplia essa noção, pois supera a ideia de uma edição fechada ou de um ciclo de notícia com início, meio e fim. Da mesma forma, esse aspecto também é uma evolução da característica atualização contínua do webjornalismo, pois os jornais feitos para a web, em sua grande maioria, são atualizados somente durante o horário de produção do jornal impresso. Bertocchi (2014) afirma que no ambiente complexo em que a produção de conteúdo se encontra, atualmente, um dos grandes desafios do jornalismo é superar a estrutura tradicional do formato narrativo ou do formato notícia enquanto algo fechado e finalizado, com começo, meio e fim, sendo o fim o momento em que aquele produto é impresso e entregue ao leitor, ou ainda, quando vai ao ar e está disponível para leitura. No lugar dessa linearidade 
tradicional do processo, a autora propõe que se enxergue a narrativa como algo circular e ainda mais sistêmico, onde há continuidades em formatos adaptativos e também leveza do produto apresentado. Anderson, Bell e Shirky (2013) também apontam a necessidade de se superar o modelo de produção jornalística em que o profissional apura, redige, formata, empacota e distribui, terminando assim seu trabalho. Para os autores, é necessário que se veja o processo como um fluxo constante de informação levada ao usuário, a partir de diversos formatos destinados a múltiplos dispositivos. Esses dispositivos requerem o desenho de narrativas que levem em consideração o caráter pervasivo da comunicação e atuem de forma contínua e sistemática, "sem ponto de origem e término estáticos e definitivos, prontas para novas formatações e desformatações, e inclusive deformações, com designs distintos em diferentes telas, sem estruturas fixas" (BERTOCCHI, 2014, p.73). O jornalismo ubíquo também tira proveito das características dos dispositivos móveis digitais que potencializam a transmissão de conteúdo ao vivo e geograficamente dispersa. Torna-se mais fácil fazer transmissões de locais onde estão ocorrendo determinados eventos importantes, ou então, transmitir um apanhado de informações publicadas pelo público que está presente nesses locais. Um dos exemplos mais atuais desse tipo de transmissão são os "lives" feitos na plataforma do Facebook. A maioria dos veículos de comunicação adotou a ferramenta e faz transmissões tanto de locais específicos quanto da própria redação para levar conteúdo ao público. Outras plataformas como Instagram, Snapchat e Periscope também vêm sendo apropriadas pelo jornalismo ubíquo para potencializar a transmissão ao vivo de informação.

\section{- Automação}

O jornalismo ubíquo existe dentro de um contexto de fortalecimento da inteligência artificial, do aprendizado de máquinas e potencialização da autonomia dos dispositivos a partir de algoritmos. Assim, os sistemas são programados para que possam interagir entre eles sem, necessariamente, uma mediação humana. Isso significa que muitas informações recebidas e enviadas ao smartphone, por exemplo, podem ser processadas automaticamente a partir de um 
estímulo geolocalizado ou de comportamento do público (temperatura, movimento, hora etc.). Uma notícia pode ser enviada ao dispositivo no momento em que o usuário passa por determinado local. Um alerta de meteorologia pode ser enviado quando o dispositivo envia a informação de que trocou de cidade. A compra de ingressos para um espetáculo ou jogo de futebol utilizando o pagamento pelo celular pode disparar o envio de notícias sobre os artistas que fazem parte do show ou sobre os times que disputam a partida. Essas interações não ocorrem somente com o ambiente externo, mas também entre dispositivos como telefones, satélites e bases de dados. Esse aspecto está relacionado à compreensão do dispositivo não apenas como objeto para consumo de informação, mas também como um sensor que capta e redistribui informação própria, possibilitando que esses sinais também sirvam de estímulo para produção e consumo de informação. "Tudo vai estar conectado; desde uma impressora até um semáforo, passando pelo nosso próprio carro e a garagem em que estacionamos, os objetos começam a 'falar' entre eles" (TÁSCON; COULLAUT, 2016, p. 9) ${ }^{58}$. Essa categoria apresenta alguns elementos a serem considerados para o presente e também para o futuro do jornalismo ubíquo. $\mathrm{Na}$ atualidade, muitos aplicativos já experimentam sistemas de recomendação de conteúdo aos usuários, que funcionam a partir de algoritmos que constroem perfis de uso e gosto da audiência. Além disso, empresas como o Quartz e o próprio The Guardian já investem em interfaces conversacionais a partir do uso de bots. Bots são uma espécie de linguagem de programação que atua como um robô e interage com o usuário de forma mais dialógica e tenta se assemelhar a um comportamento humano. Outro exemplo do uso de inteligência artificial no jornalismo são as notícias escritas por softwares. A agência de notícias AP (Associated Press) já utiliza esse tipo de tecnologia para criar conteúdos de economia e esportes, principalmente aqueles que entregam fundamentalmente dados aos leitores, resultados do fechamento do mercado financeiro ou o placar final de uma partida de futebol.

\footnotetext{
58 Tradução da autora, trecho original: "Todo va a estar enlazado; desde una impresora a un semáforo, pasando por nuestro propio coche y el garaje en el que aparquemos, los objetos empiezan a "hablar" entre ellos".
} 


\section{- Formato ubíquo}

Dispositivos móveis digitais como celulares, smartphones, e-readers e tablets possuem uma lógica própria de funcionamento diferente daquela que corresponde, por exemplo, aos computadores pessoais. A experiência de acesso ou interação com a informação, nesses casos, tem cada vez mais dinamicidade e, por isso, as interfaces e as experiências de uso desses artefatos demandam formatos adaptados a suas lógicas de funcionamento e operação. Ramos (2011) explica que a informação precisa ser modelizada em formatos adequados e próprios ao meio, ou seja, no caso do jornalismo ubíquo é preciso levar em consideração as características dos dispositivos em que os formatos serão apresentados para que se possa modelizar a informação de acordo com a lógica do artefato. Os aspectos técnicos próprios dos dispositivos móveis digitais proporcionam, por exemplo, a tactilidade ao usuário, o que faz com que o design digital precise se adaptar a essas condicionantes tecnológicas, visuais e estéticas, além de levar em consideração questões como arquitetura de informação e usabilidade. Transpor formatos de outros modelos, como impresso e desktop, para essas plataformas acaba incorrendo numa subutilização das potencialidades oferecidas por esses artefatos. Possibilidades como narrativas interativas, gamificação, textos em movimento, vídeos curtos e disparados automaticamente são alguns dos exemplos dos formatos mais adaptados aos dispositivos móveis. Além disso, o uso da realidade aumentada e da realidade virtual são exemplos do potencial oferecido por esses novos formatos (PAVLIK, 2014). Jornais como o The New York Times, The Guardian e El País já possuem aplicativos específicos e exclusivos para a distribuição de conteúdo criado para visualização em realidade virtual, com equipes destacadas especialmente para esse trabalho. Salaverría (2014) fala num enriquecimento dos códigos comunicativos no contexto ubíquo dos dispositivos móveis digitais, o que nos leva a experiências também mais sensoriais que podem envolver vibração (percepção corporal), por exemplo.

Os oito elementos multimédia [texto, fotografia, iconografia e ilustração, gráficos, vídeos, animação digital, discurso oral, música e efeitos sonoros, vibração] que temos vindo a analisar são assimilados mediante três sentidos corporais: visão, audição e - no caso da vibração - o tacto. Todavia, existem cada vez mais evidências de que no futuro iremos contar com novos formatos 
que irão apelar aos demais sentidos; isto é, além dos elementos direcionados para a visão e audição, passaremos a dispor de elementos tácteis e, quem sabe, até pode ser que passemos a receber informação através do olfacto e do paladar (SALAVERRÍA, 2014, p. 38).

Assim, o que o autor propõe é que pensemos numa multisensorialidade como característica para os formatos ubíquos que podem ser criados quando do aproveitamento das potencialidades dos dispositivos móveis digitais.

\section{- Redistribuição e re-produção}

A conexão permanente e a facilidade de uso dos dispositivos móveis digitais potencializa a capacidade de redistribuição e re-produção dos conteúdos que são consumidos através deles. Isso quer dizer que os usuários que estão em movimento e recebem alguma informação relacionada ao seu contexto podem facilmente compartilhar essa informação com seus pares e também adicionar a ela outros dados obtidos a partir de suas observações e interações feitas naquele momento. O compartilhamento pode ser feito por mensagens de áudio, por mensageiros instantâneos, como o WhatsApp, por vídeo pessoal através de redes como o Snapchat, ou seja, ampliam-se os canais e as formas como a informação pode ser redirecionada e redistribuída. Além disso, também se facilita a colaboração do público com o próprio veículo com o envio de mais informações ou opiniões. O usuário acaba agindo, nesse caso, também como um mediador da informação, pois ele redistribui e coproduz os conteúdos que circulam pelas redes que frequentam.

\section{- Personalização bidirecional}

No jornalismo ubíquo, como explica Salaverría (2016a), a informação não é apenas móvel e ubíqua, mas é personalizada. O conteúdo é desenvolvido para atender aos anseios mais específicos e pessoais do usuário final, e isso é possível em função de uma personalização de duas vias. Isso significa que tanto o público é capaz de definir quais informações quer receber e de que forma as quer receber, quanto o veículo é capaz de receber informações enviadas pelos sensores dos dispositivos e construir perfis de leitores a partir desses dados. Gosto, gestos, 
tato, voz, geolocalização e hábitos de consumo são exemplos de alguns dos tipos de informação que podem ser capturados por esses sensores e utilizados para entregar o conteúdo de forma mais adequada ao interesse do leitor. Além dis so, o público também conta com mais possibilidades de personalização do consumo, uma vez que essa é potencializada nos dispositivos móveis digitais por características dos próprios artefatos e seus sistemas operacionais. Um exemplo disso é o usuário que opta por receber alertas de notícias dos aplicativos jornalísticos que possui no smartphone, no entanto, à noite, ativa a opção "não perturbe" do sistema para que não tenha o sono interrompido por nenhuma notificação.

\section{- Redação mobile first}

Uma das características do jornalismo ubíquo também é a transformação que ele causa nas redações jornalísticas. O modelo de produção mobile first, onde a prioridade é dada para a produção de conteúdo para os dispositivos móveis digitais, já é uma realidade em veículos como, por exemplo, El País e O Estado de S. Paulo. Os jornalistas mudam suas rotinas de produção para produzir e formatar o conteúdo com foco principal para smartphones. Além disso, a rotina da redação também é alterada, sendo modificados os horários das reuniões de pauta e a própria disposição das mesas e dos profissionais dentro do espaço físico, agregando a um centro produtor de conteúdo móvel telas que informam em tempo real a audiência do veículo em todas as plataformas e o desempenho da concorrência. "As mudanças tanto na coleta, análise e visualização do grande volume de dados teria que afetar não apenas a informação que se produz para o leitor, quanto também o próprio modelo de negócio dos meios de comunicação" (TASCÓN; COULLAUT, 2016, p. 51). A empresa se adapta e modifica seus modos de agir, seus padrões de produção, seu modelo de negócios e até mesmo sua cultura para privilegiar um tipo de produção que, no caso de marcas jornalísticas ligadas ao jornal impresso, não era, até então, o seu principal foco e produto. 


\section{- Multicompetências}

Os novos dispositivos de consumo de informação em mobilidade, aliados a um novo formato de apresentação da narrativa que leva em consideração o sistema e as bases de dados, formam um conjunto inovador que demanda do entorno uma série de "killer competências". Por "killer competências", quer-se propor a ideia de que há uma nova série de saberes imprescindíveis aos jornalistas e às empresas que produzem conteúdo jornalístico que se fazem indispensáveis para realização de um produto que atenda às demandas do público. No vocabulário de tecnologia, é comum utilizar o termo killer applications ou killer app para designar um software que seja tão interessante e desejado que justifique a compra de um hardware específico apenas para o seu consumo. As mudanças nas organizações que comandam marcas jornalísticas de legado fazem com que a redação passe a incluir não apenas jornalistas, mas também designers, programadores, engenheiros, entre outros. Salaverría (2016b) coloca que, nos últimos anos, as redações têm diversificado os tipos de profissionais que produzem seus periódicos. Nos maiores jornais, os profissionais começam a se especializar e surgem repórteres multimídia, redatores digitais, editores de mídias sociais, designers multimídia, infografistas digitais, produtores de vídeo para $w e b$, analistas de métricas e audiência, jornalistas de dados, editores de dispositivos móveis, editores $w e b$, entre outras denominações que são associadas aos profissionais que precisam adquirir diferentes e novas competências para dar conta do novo produto distribuído pela empresa.

Esse conjunto de categorias elencadas até aqui não é definitivo nem imutável. Esse é um levantamento e um aprofundamento teórico que realizamos para este trabalho, na medida em que consideramos que seria insuficiente analisar os produtos jornalísticos desenvolvidos no atual contexto de espaços híbridos e ubiquidade, a partir de características e categorias elencadas anteriormente por autores que se debruçaram sobre o jornalismo feito somente na e para a web. Ou seja, ao propormos a adoção do conceito de jornalismo ubíquo, naturalmente se fez necessário construir uma base teórica de observação desse mesmo jornalismo nos produtos consumidos pelos usuários. Partimos da ampla contribuição da base teórica desenvolvida nos estudos sobre o jornalismo 
digital, webjornalismo, jornalismo online, jornalismo móvel, mas apresentamos um novo conjunto de categorias, a fim de que possamos usá-lo como instrumento de observação em nossa pesquisa.

Para que possamos nos aprofundar ainda mais nessas potencialidades do jornalismo ubíquo e compreendê-las mais detalhadamente, propomos no próximo capítulo uma discussão envolvendo o conceito de narrativa sistêmica, as propriedades dos dispositivos móveis digitais e, consequentemente, do jornalismo que pode ser apresentado neles. O objetivo é que possamos aprofundar o conhecimento de como funciona o jornalismo ubíquo e, mais especificamente, como foco desta pesquisa, do formato da narrativa sistêmica dentro deste novo contexto de produção de conteúdo. 


\section{NARRATIVA, SISTEMA E FORMATO}

O objetivo deste capítulo é apresentar alguns dos elementos que fazem parte do formato da narrativa que encontramos nos smartphones dentro das especificidades do jornalismo ubíquo. Para isso, buscamos explicar o conceito de narrativa sistêmica proposto por Bertocchi (2014), problematizando-o com relação aos dispositivos móveis digitais, unindo-o à proposta de jornalismo ubíquo para, a partir daí, encontrar elementos relativos ao formato desta narrativa sistêmica em smartphones. Partimos do raciocínio (já previamente explicitado no primeiro capítulo do trabalho) de que toda narrativa digital é sistêmica, composta por diversas camadas de atores que, por sua vez, se apresentam de forma diferente nos dispositivos móveis digitais e, por isso, justificam um trabalho de investigação específico com relação a elas.

Sendo assim, uma vez que estamos tratando de um jornalismo ubíquo e do formato que esse jornalismo assume em smartphones, buscamos na última parte deste capítulo discutir as características que fazem parte do design dessa narrativa que se apresenta de forma diferente nesses dispositivos em função das características técnicas oferecidas e das potenciais affordances do dispositivo. A união desses elementos e das próprias categorias do jornalismo ubíquo, destacadas no capítulo anterior, serve de base para a construção do instrumento de análise e observação que será usado na pesquisa empírica.

\subsection{Narrativa sistêmica}

Em sua pesquisa de Doutorado, Bertocchi (2014) afirma que no ambiente complexo em que a produção de conteúdo jornalístico se encontra atualmente, um dos grandes desafios do jornalismo é superar a estrutura tradicional da narrativa, ou da notícia, enquanto algo fechado e finalizado, com começo, meio e fim, sendo o fim o momento em que aquele produto é impresso e entregue ao leitor, ou ainda, quando vai ao ar e está disponível para leitura. No lugar dessa linearidade tradicional do processo, a autora propõe que se enxergue a narrativa como algo circular e mais ainda sistêmico, onde há continuidades em formatos adaptativos e também leveza do produto apresentado. Anderson, Bell e Shirky (2013) também apontam a necessidade de se superar o modelo de produção jornalística em que o profissional apura, redige, formata, 
empacota e distribui, terminando assim seu trabalho. Para os autores, é necessário que se veja o processo como um fluxo constante de informação levada ao usuário a partir de diversos formatos destinados a múltiplos dispositivos.

A proposta de Bertocchi (2014) é que a narrativa em si seja vista a partir do conceito de sistema. Um sistema é formado por objetos ou entidades que se interrelacionam. Sendo assim, a narrativa se configura não num produto final estático e definido, mas sim num resultado mutante e contínuo que pode se adaptar ao formato necessário e ao dispositivo em que será visualizada. Em 2006, a autora já propunha que a narrativa digital estava diretamente ligada à multimidialidade, hipertextualidade e interatividade. Com o desenvolvimento da tecnologia e, consequentemente, da indústria jornalística com ela, esses conceitos já aparecem como dados e intrínsecos ao conteúdo digital, o que faz com que se precise avançar na conceituação do formato narrativo atual, dando conta de questões como materialidade, mobilidade, bancos e fluxos de dados.

Bertocchi (2016) defende que a narrativa contemporânea deve ser vista mais como fluxo e menos como um ponto final de um processo com etapas rigidamente estabelecidas. Para ela, na narratologia pós-clássica, as condições da escrita e do contexto ganham mais importância junto às "plataformas e equipamentos tecnológicos, as bases de dados, os algoritmos e a inteligência artificial" (p. 40). Isto faz com que as narrativas atuais se apresentem de forma mais complexa e com isso tenham formatos diferentes e até mesmo experimentais.

\footnotetext{
Expandimos aqui a perspectiva da narrativa clássica que toma a narrativa jornalística como agenciamento dos fatos e a colocamos como agenciamento coletivo entre os estratos de um sistema narrativo ou, de forma mais reduzida: como sistema narrativo. Expansão aqui significa dilatação da visão, e não negação ou discordância em relação às construções e aos percursos teóricos que precedem este livro. Propomos, sim, algum tipo de prolongamento para a noção de narrativa (BERTOCCHI, 2016, p. 48).
}

Baseando-se em Manovich (2013), a autora adota a ideia de que as narrativas atuais se configuram muito mais por um fluxo de dados do que pela base de dados em si. Além disso, Bertocchi aponta outros elementos que, segundo ela, devem ser levados em consideração como pertencentes ao processo de modelagem das narrativas, alguns deles são: algoritmos internos ao sistema de base de dados, semântica das bases de dados, 
relação entre o sistema e APIs (Application Programming Interface ${ }^{59}$ ) externas de outros serviços; e o sistema publicador da narrativa, CMS (Content Management System ${ }^{60}$ ).

Podemos perceber que estes elementos apontados pela autora são elementos técnicos, atores não humanos, ou seja, aqui mais uma vez, vemos a interferência e o agenciamento provocado por estes objetos no processo de construção da narrativa. Especificamente com relação ao sistema publicador, ele pode ser considerado o primeiro editor de uma narrativa jornalística, segundo o jornalista David Cohn ${ }^{61}$. As propriedades técnicas disponíveis dentro do sistema publicador são capazes de determinar que tipo de narrativa poderá ou não ser construída. A possibilidade de usar algoritmos, o uso da memória da base de dados, tagueamento ${ }^{62}$, interatividade, multimidialidade, interação com outros serviços, entre outras coisas são elementos que precisam estar previstos no CMS. Ou seja, o agenciamento deste agente não humano é fundamental no processo de construção da narrativa jornalística. A narrativa jornalística sistêmica, portanto, configura-se como a atuação coletiva de diversos atores, humanos e não humanos, sendo importante diferenciá-la, por exemplo, de conjuntos de elementos que não possuem interação entre si e que seu resultado final não vá além da soma de suas partes.

\begin{abstract}
A narrativa começa a ser construída em cima da codificação maquínica. Conforme esta camada de base dialoga com outras camadas, vai-se formando um tecido narrativo complexo, até então termos uma substância tangível e reconhecível no ecrã pelo usuário: a narrativa reúne substância e torna-se, por fim, um formato narrativo digital. Assim, conforme rajadas de fluxos informativos passam pelos diversos estratos do sistema, temos por fim a narrativa formatada - ou seja, renderizada, como interface reconhecível numa tela qualquer pelo humano. [...] Após sua renderização, novos endereçamentos podem ocorrer: usuários acrescentam comentários aos conteúdos, o texto narrativo pode ser partilhado em uma rede social, a narrativa pode ser subvertida. A narrativa é um sistema que não está em isolamento, mas em constante interação com outros sistemas e muitas vezes é modelada para bem atendê-los (BERTOCCHI, 2014, p. 55).
\end{abstract}

\footnotetext{
${ }^{59}$ Em tradução literal para o português API significa Interface de Programação de Aplicativos que indica um padrão de acesso determinado para um software. Ou seja, quando uma empresa desenvolve um serviço que irá se integrar a outros, ela designa uma API específica para acesso e desenvolvimento do produto. Além disso, a API também serve para que o software inicial seja utilizado de forma integrada ao que é desenvolvido posteriormente por terceiros.

${ }^{60}$ Em tradução literal para o português CMS significa Sistema de Gerenciamento de Conteúdo, que nada mais é que o sistema que uma empresa utiliza para gerenciar a publicação de conteúdo em seus mais diversos canais de comunicação, de sites a aplicativos de smartphones.

${ }^{61}$ https://medium.com/@ digidave/the-cms-is-your-first-editor-f8dc948aa500\#.38e8jn29x

${ }^{62}$ Tagueamento se refere à inserção de tags no sistema, ou seja, palavras-chave que funcionam como metadados para identificação do conteúdo na base de dados.
} 
Como expusemos no primeiro capítulo, a autora apresenta um modelo teórico do sistema narrativo jornalístico. Esse modelo busca explicitar os elementos envolvidos nas diversas fases da constituição de uma narrativa, mas se debruça de maneira mais forte sobre os momentos que envolvem a antenarrativa, ou seja, o processamento de dados e metadados que envolvem a construção do material que será exibido ao público através do formato que receberá na etapa de constituição de sua interface. Esses elementos e suas interações ficam mais bem explicitados na representação gráfica do modelo proposto pela autora (ver figura 3). Nele também é possível visualizar o ponto em que se encontram os formatos da narrativa, foco mais específico desta pesquisa.

Figura 3 - O Sistema narrativo no jornalismo digital

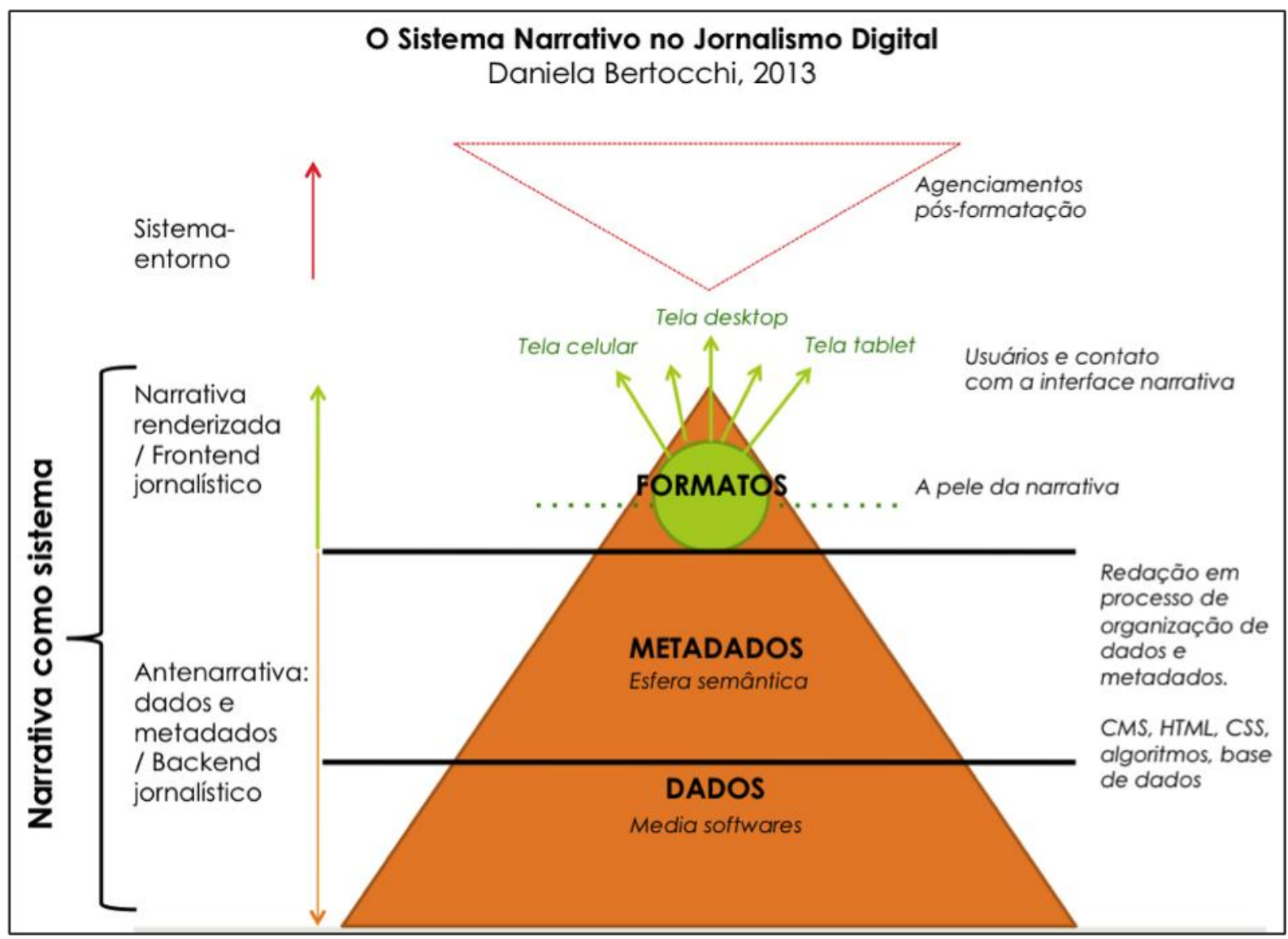

Fonte: Bertocchi (2014)

É importante ressaltar que a visão da narrativa como complexa, sistêmica e processual não é oposta ao método de análise desta pesquisa. Ao observarmos os aplicativos jornalísticos para smartphone da nossa amostra de trabalho, vamos investigar o formato da narrativa, ou seja, a renderização da narrativa na interface do dispositivo, 
ou ainda o resultado provisório das ações realizadas pelo sistema narrativo. A narrativa indica algo maior do que somente o formato, o sistema narrativo é o todo. Retomando a imagem proposta por Bertocchi, da pirâmide que representa o processo sistêmico, é esta imagem por completo que configura o sistema narrativo, aqui, especificamente, observamos o formato, a pele da narrativa, a ponta da pirâmide.

Como afirma Bertocchi (2016), a narrativa é um processo contínuo, capaz de se apresentar em múltiplos formatos, dispositivos e substâncias, de acordo com as interações e agenciamentos que são realizadas dentro do sistema e na relação sistemaentorno. "O que se vê na vitrine das telas - nesse palco costumeiramente chamado de front-end ou interface usuário ou ainda interface pública - é o que ao longo deste estudo tomamos por formatação da narrativa" (p. 56). Ao ser processo, a narrativa como um todo não acaba quando é renderizada, mas sim, entra em contato com outros sistemas e se transforma a partir daí. Redes sociais, aplicativos de relacionamento, mensageiros pessoais, agregadores de notícias, entre tantos outros são alguns exemplos de serviços que prolongam, modificam e ressignificam a narrativa.

\begin{abstract}
Rara é a empresa jornalística que, hoje, possui uma única plataforma. Mesmo que ela tenha começado como um jornal, revista, rádio ou canal de TV, cada marca de notícias hoje precisa levar em conta a forma de engajamento com seus leitores, ouvintes ou telespectadores através de um número crescente de plataformas. Isso pode significar tanto Twitter, Facebook e Snapchat, quanto algum das centenas de novos tipos de aplicativos. As pessoas podem estar em seus telefones, tablets ou computadores. Elas podem estar em um carro, numa corrida ao ar livre, no metrô, almoçando ou quase dormindo na cama. Tudo isso implica em desenhar uma multiplicidade de possíveis experiências em torno do mesmo conteúdo noticioso e considerar uma gama de diferentes contextos de consumo. As empresas jornalísticas também precisam considerar o que o leitor, telespectador ou ouvinte irá fazer com a notícia que receber, além de ler, ver ou ouvir. Em resumo, cada parte entregue do conteúdo noticioso é incorporada em um complexo sistema de experiência e possíveis ações (CHAPLIN, 2016, p. 37) ${ }^{63}$.
\end{abstract}

Bertocchi (2016) e também Lima (2014) defendem que as partes atuantes no sistema precisam compartilhar metas e objetivos a fim de que o resultado do sistema

\footnotetext{
${ }^{63}$ Tradução da autora, trecho original: "Rare is the news organization today with a single platform. Even if it started out as a newspaper, magazine, radio station, or TV channel, each news outlet now has to contend with how to engage with its readers, listeners, or viewers across a growing number of platforms. That might mean Twitter, Facebook, and Snapchat, or one of hundreds of new kinds of apps. People might be on their phones, tablets, or computers. They might be in a car, out for a run, on the subway, eating lunch, or half asleep in bed. This all entails designing a multitude of possible experiences around the same piece of news, and considering a range of different contexts for consumption. News organizations must also consider what the reader, viewer, or listener is going to do with any given piece of news, besides just reading, viewing, or listening to it. In short, every piece of news delivered is embedded in a complex system of experience and possible action".
} 
seja o esperado. O alinhamento entre as partes é responsável por uma formatação mais adequada da narrativa, levando em conta, inclusive o alinhamento com os serviços e sistemas que entrarão em interação com a narrativa após sua visualização.

Bertocchi coloca a ideia de formato a partir do trabalho doutoral de Ramos (2011) que apresenta a noção de formato para designar a condição para a escrita do jornalismo. Segundo a autora, um dos desafios do jornalismo atual é entender como selecionar e combinar bases e fluxos de dados a fim de criar narrativas em formatos digitais. Para ela, "os formatos modelizam as linguagens digitais” (p. 6). Em algumas mídias, como rádio e televisão, o formato é mais evidente, pois é a forma como o produto jornalístico será organizado para se inserir numa grade de programação.

No jornalismo ubíquo, o formato é modelizado pelo design informático e suas diversas classes de códigos. Nesse caso, Machado (2007) esclarece que formato não é gênero, pois enquanto na televisão ele se caracteriza pela "produção de esferas de uso da linguagem", na rede ele se caracteriza por uma síntese informática, que no caso tratado aqui, envolveu códigos, sistemas, jornalistas, programadores e outros diversos atores. $\mathrm{O}$ formato é o design da informação.

\footnotetext{
Os autores consideram que os aspectos do formato do design digital restringem-se à área de navegação na tela, à própria navegação e à rolagem, o que não é a nossa concepção, já que para nós o formato é resultado do desenho informático, o que pode conter muitas variáveis, pois a execução do design não é física e palpável, mas um processamento de códigos e linguagens na tela digital, uma síntese do design informático (RAMOS, 2011, p. 45).
}

Baseada em Machado (2007), Ramos acrescenta que a informação precisa ser modelizada em formatos adequados e próprios ao meio, ou seja, no caso do jornalismo digital é preciso levar em consideração as características dos dispositivos em que os formatos serão apresentados para que se possa modelizar a informação de acordo com a lógica do artefato. Atualmente, as marcas jornalísticas que atuam em plataformas digitais apresentam seus produtos organizados em formatos que remetem aos já tradicionais operados pela televisão ou pelo jornal impresso. Para Ramos (2011), isso ocorre porque as empresas recorrem a essas modelizações para atualizar a memória cultural da sociedade que tem como referência um formato jornalístico anterior. Ao mesmo tempo em que o formato antigo modeliza o formato atual, o inverso também ocorre, com muitos jornais impressos adotando linguagens rápidas e de mosaico em suas 
páginas, na tentativa de atrair o leitor mais apressado, mas tornando sua configuração e identidade nebulosas diante do público mais atento.

O tablet, por exemplo, é um artefato inserido numa era específica que adota modelos de usabilidade anteriores, principalmente no que diz respeito ao caminho de leitura. Para Pires (2010), a leitura hipertextual não nasce com a tecnologia digital, entretanto, no livro impresso, existe uma sequência imposta pelo objeto e uma relação própria entre esse objeto e a narrativa ali apresentada, as páginas pressupõem uma ordem por mais que o leitor possa saltá-las. No âmbito da tecnologia digital, a mudança no artefato, no dispositivo e na materialidade deste faz com que o leitor desperte para o aprendizado de uma nova forma de leitura, além de poder adicionar à narrativa novos elementos de estímulo. “[...] [a leitura na tela é] uma leitura fragmentada na qual a percepção global da obra, imposta pela própria materialidade do objeto, está sempre presente" (CHARTIER, 2002, p. 43).

Bertocchi (2014) acrescenta à noção de formato, a sua interpretação de que "o formato é capaz de revelar o comportamento de todo um sistema" (p. 72), na medida em que ele é fruto não apenas da base de dados, mas da interação de todos os elementos envolvidos no processo narrativo, demonstrados mais especificamente na representação gráfica de seu modelo. A autora também acrescenta a discussão que diferencia gêneros de formatos. Para ela, os gêneros jornalísticos são "modelos textuais caracterizados por certas convenções estilísticas e retóricas" identificáveis por autores e leitores que diferenciam, por exemplo, opinião, informação e entretenimento.

O jornalismo ubíquo possui gêneros derivados do jornalismo impresso, por essa ser sua referência mais inicial e direta, mas também atualiza o conjunto com o surgimento de novos gêneros. No modelo sistêmico de narrativa do jornalismo digital, o gênero é anterior ao formato.

\begin{abstract}
Assumimos aqui, portanto, que um certo gênero textual jornalístico pode ter mais de um formato. A notícia pode ter vários formatos. O gênero mantém-se como contrato. O formato é mais livre, impõem- se como um contrato extremamente provisório e sem fidelidade, que vale apenas para aquele minuto do acesso. O formato é mais adaptativo que o gênero. O formato pode ser compreendido, portanto, como o design do gênero (Machado). Nesta condição, funciona como um artefato de produção jornalística, como uma maneira de interação (BERTOCCHI, 2014, p. 78)
\end{abstract}

É o gênero que vai designar o formato a ser construído, na medida em que as formas são amplamente multiplicáveis, mas os gêneros demandam uma correlação mais 
profunda com elementos já produzidos anteriormente e também do conhecimento prévio da audiência (BERTOCCHI, 2014). Machado (2007) acrescenta que o formato é o “design do gênero" e Bertocchi (2014) finaliza esclarecendo que o formato é "a configuração da materialidade discursiva, condicionada pelo dispositivo". Ou seja, um mesmo gênero jornalístico pode ser apresentado em vários formatos, que por sua vez aparecem na interface do dispositivo.

Uma maneira simples de definir interface é proposta por Johnson (2001). Para o autor, "a palavra se refere a softwares que dão forma à interação entre usuário e computador" (p. 17). O computador, além de manipular sequências de zeros e uns, precisa "se fazer entender" ao usuário de uma maneira compreensível e a interface atuaria como o tradutor das diferentes linguagens do computador e do usuário. O autor ainda afirma que, essa relação viabilizada pela interface é uma relação semântica, cheia de significado e expressão. No caso dos dispositivos móveis digitais esta noção de interface se amplia para abarcar a característica de interface social, conceito proposto por Souza e Silva (2006) e já explicitado no capítulo anterior, e também o aspecto de tactilidade, ou seja, a interface gestual, que pode ser controlada pelo toque e gestos das mãos. Farman (2012) chama a atenção para a possibilidade de um conceito mais aberto de interface. Segundo ele, é possível considerar a interface como o ambiente que medeia e constrói a experiência do usuário.

\subsection{Narrativa sistêmica ubíqua}

Como afirma a própria autora do conceito de narrativa sistêmica, Daniela Bertocchi (2016), a narrativa enquanto sistema é composta por diversas camadas, estas estão, obviamente, relacionadas às características do sistema em que a narrativa é construída e também do dispositivo para o qual ela é formatada. "O que o usuário final vê é a soma das camadas agenciadas por vários profissionais, usuários finais e máquinas" (p. 65). Assim, partimos da percepção de que narrativas formatadas para smartphones se encontram dentro de um sistema com diferentes camadas do que aquelas desenhadas para uma tela de computador pessoal, por exemplo, isso porque se alteram os atores e sistemas envolvidos no processo. 
O consumo de conteúdo jornalístico via smartphone possui como elementos participantes, por exemplo, o plano de dados e a conexão a qual o usuário tem acesso, a cobertura da operadora no local onde o usuário está, o local de onde está sendo realizado o acesso e todos o contexto ligado a ele, o possibilidade de o usuário ter contato com o telefone a qualquer momento, o local onde o telefone está guardado, o volume dos sinais sonoros emitidos pelo dispositivo, o sistema operacional que está sendo utilizado pelo usuário, o modelo do telefone, a versão do aplicativo que está sendo usada, o tamanho da tela, o tamanho da mão do usuário, a comodidade no uso do aparelho, as preferências que foram configuradas pelo usuário com relação ao recebimento de notificações, identificação do aparelho e de seu comportamento de uso, entre outros.

\begin{abstract}
Caracteristicamente, as plataformas móveis agrupam as relações entre os distintos atores em torno do controle do canal de distribuição de conteúdos e serviços, constituído sobre as chamadas lojas de aplicativos (app stores) e assentado sobre o domínio do sistema operacional, do qual depende tanto o entorno de programação, como a interface do usuário. Assim, além de incluir relações específicas (geralmente externas e muitas vezes tensas) com os operadores das redes, as plataformas móveis articulam o hardware de acesso (dispositivos móveis e fixos), o sistema operacional e sua interface de usuário, um software de gestão de conteúdo/aplicativos que também opera como elemento de controle da atividade do usuário (reunindo informação sobre seu perfil e preferências e limitando as formas de ingresso e execução com objetivo de minimizar a integração de conteúdo de fora da plataforma) e, finalmente, um kit de desenvolvimento de software (SDK) com linguagem e parâmetros de programação próprios da plataforma (CASTELLET; FEIJÓO, 2013, p. 31) $)^{64}$.
\end{abstract}

Castellet e Feijoó (2013) apresentam uma proposta de visão das atividades e dos atores que participam do sistema móvel (Figura 4) e, em consonância à proposta de Bertocchi (2014), a organização é feita em camadas. O quadro reúne três grupos de atividade: criação e produção; entrega, distribuição e acesso; uso consumo e interação. As camadas propostas pelos autores estão diretamente ligadas às esferas das quais

\footnotetext{
${ }^{64}$ Tradução da autora, trecho original: "Característicamente, las plataformas móviles agrupan las relaciones entre los distintos actores en torno al control del canal de distribución de contenidos y servicios, conformado sobre las denominadas tiendas de aplicaciones (app stores) y asentado sobre el dominio del sistema operativo, del que dependen tanto el entorno de programación, como la interfaz de usuario. Así, además de incluir relaciones específicas (generalmente externas y no pocas veces tensas) con los operadores de redes, las plataformas móviles articulan el hardware de acceso (dispositivos móviles y fijos), el sistema operativo y su interfaz de usuario, un software de gestión del contenido/aplicaciones que también opera como elemento de control de la actividad del usuario (recopilando información sobre su perfil y preferencias y limitando las formas de ingreso y ejecución con el fin de minimizar la integración de contenido ajeno a la plataforma) y, finalmente, un kit de desarrollo de software (o SDK) con el lenguaje y parámetros de programación propios de la plataforma".
} 
falamos anteriormente, onde a transformação tecnológica e cultural interfere diretamente: produção, distribuição e consumo de conteúdo jornalístico.

Figura 4 - Esquema do ecossistema móvel

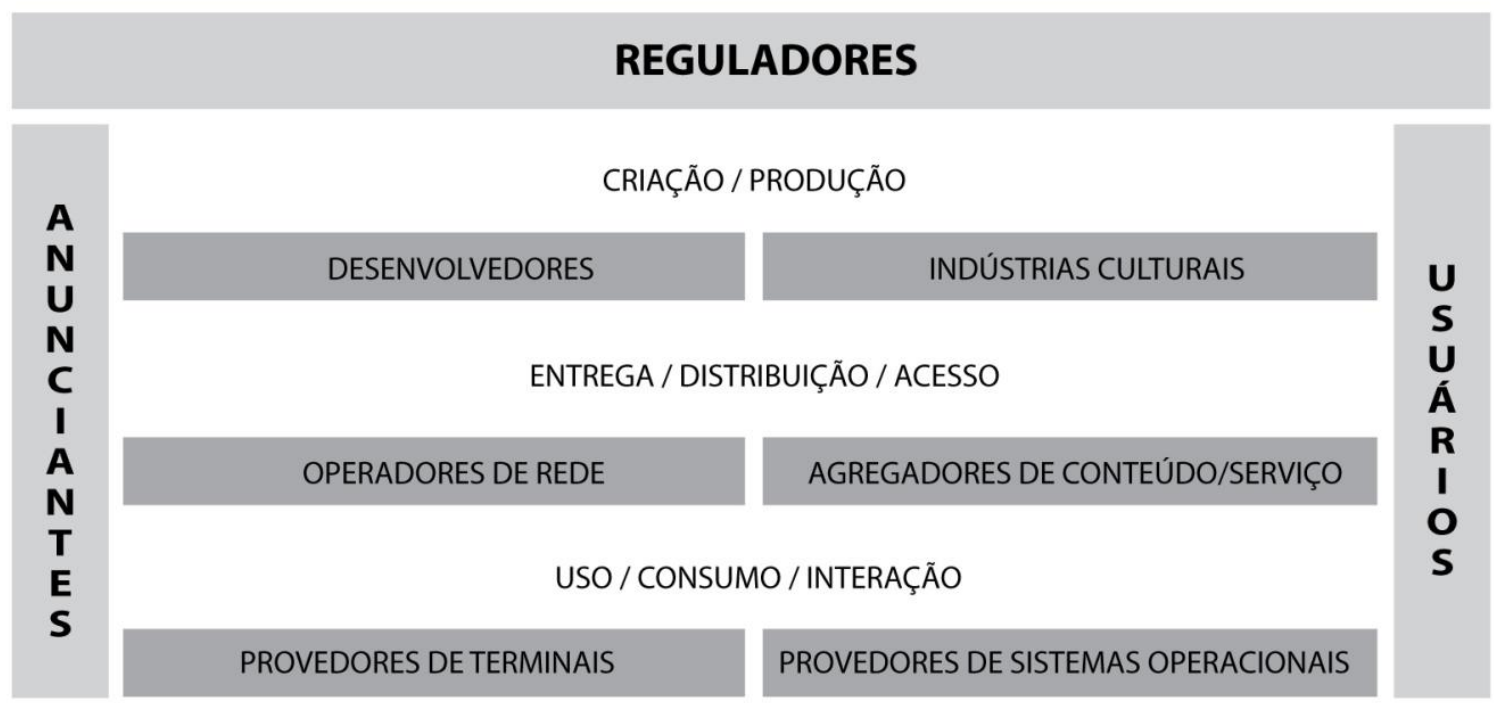

Fonte: Castellet e Feijoó (2013)

$\mathrm{Na}$ camada da criação e distribuição estão os desenvolvedores, ou seja, programadores e designers responsáveis pela criação dos apps que são distribuídos nas lojas de aplicativos e o que os autores chamam de indústrias culturais. Dentro desta categoria estão as empresas jornalísticas, indústria editorial e musical, cinema, entretenimento, entre outros. Enquanto os desenvolvedores são capazes de produção inovação constante, isto não ocorre com as empresas convencionais, segundo os autores, com exceção dos serviços de streaming, tanto para música quanto no audiovisual, dentro da área de indústrias culturais.

Os operadores de rede são as empresas operadoras de telefonia e conexão de banda larga. Os agregadores são as ferramentas que facilitam o acesso à informação disponível na internet. Alguns exemplos de agregadores são o Google e o Facebook. Com os dispositivos móveis, os agregadores se adaptam à nova realidade e passam a funcionar integrados ao sistema e não como um endereço num navegador, alguns exemplos são a assistente pessoal dos smartphones da Apple, Siri, e o Google Now, que integra serviços do Google em dispositivos Android e permite comando de voz. 
Os provedores de terminais são as empresa fabricantes dos dispositivos móveis digitais. Segundo os autores, a relação entre usuários e seus smartphones, por exemplo, é de maior apego na medida em que estes são dispositivos pessoais, carregados consigo para todos os lados e auxiliares em inúmeras tarefas cotidianas. Para os autores, quando se faz uma ligação para um telefone fixo, nossa mente faz a conexão de que estamos ligando para um local, no entanto, quando chamamos um número de celular estamos ligando para uma pessoa especificamente. O dispositivo possui um significado pessoal para o usuário e esta relação que já é pessoal entre usuário e dispositivo móvel digital pode ser amplificada com os wearables ou vestíveis, como relógios e óculos, fazendo com que os dispositivos adquiram mais fortemente o caráter de extensões do homem.

Os sistemas operativos são obviamente os sistemas operacionais através do quais os dispositivos operam, os mais conhecidos são o iOS, da Apple, e o Android, do Google. Segundo os autores, os sistemas operacionais são capazes de delimitar o terreno pelo qual vai transcorrer a experiência do usuário, na medida em que os desenvolvedores precisam se adaptar às regras dos sistemas para criar aplicativos e os provedores precisam ser capazes de criar aparelhos adequados para o funcionamento com determinando sistema. Anunciantes e usuários são exatamente o que os termos indicam e reguladores são os marcos legislativos que definem as regras sobre o funcionamento da rede e dos conteúdos nela presentes. No Brasil, por exemplo, um dos nossos reguladores é o Marco Civil da Internet.

A partir desta proposta apresentada por Castellet e Feijóo (2013), é possível apreender um pouco mais da noção de que os dispositivos móveis digitais fazem com que as camadas dos sistemas se alterem e, muitas vezes, se tornem mais complexas. Olhando para as camadas utilizadas por Bertocchi (2014) na representação gráfica da narrativa sistêmica (ver Figura 4, deste Capítulo), a antenarrativa nos dispositivos móveis digitais é composta por diferentes códigos de programação, diferentes sistemas de publicação adaptados ao produto para smartphones, metadados diferentes conectados a bases de dados mais amplas, algoritmos ligados à capacidade dos dispositivos funcionarem enquanto sensores, entre outros. Com relação à pele da narrativa, ou seja, ao formato que o conteúdo receberá na interface do smartphone, este também possui atores e camadas diferentes daquelas empenhadas no formato do computador pessoal, principalmente no que se refere à adaptação da narrativa ao tamanho da tela e às potencialidades oferecidas pelo dispositivo. Como explicamos amplamente no capítulo 
anterior, os dispositivos móveis digitais resignificam as formas de interação dos usuários com os conteúdos e também dos próprios conteúdos com os artefatos, isso significa dizer que a narrativa sistêmica no smartphone possui especificidades que justificam nosso interesse e empenho de pesquisa.

Os espaços híbridos de vivência e os dispositivos móveis contribuem para despertar no sujeito novos comportamentos de consumo de informação. Os dispositivos móveis possuem affordances diferentes daquelas disponíveis em outros tipos de artefatos. Gibson (1986) conceitua affordance (o termo não possui uma tradução para o português) como aquilo que o ambiente/objeto oferece, provê, possibilita a quem interage com ele. Para o autor, os objetos detém determinadas affordances previstas em sua criação ou inerentes a sua natureza e essas não mudam de acordo com a necessidade do interagente ou de acordo com sua percepção. "O objeto oferece o que ele oferece porque ele é o que é” (p. 139).

\begin{abstract}
Um importante fato sobre as affordances do ambiente é que elas são objetivas, reais e físicas, diferentemente de valores e significados, que são normalmente subjetivos, fenomenológicos e mentais. Na verdade, uma affordance não é nem uma propriedade objetiva nem subjetiva; ou é os dois se você desejar. Uma affordance ultrapassa a dicotomia de subjetivo-objetivo e nos ajuda a entender a insuficiência dessa divisão. Ela é igualmente um dado do ambiente e um dado do comportamento. Ela é física e psíquica, ao mesmo tempo em que não é nenhuma. Uma affordance aponta para os dois caminhos, o do ambiente e o do observador (GIBSON, 1986, p. 129) ${ }^{65}$.
\end{abstract}

Greeno (1994) explica que o conceito de affordance é útil para pensarmos sobre aspectos do sistema de interações entre agentes e situações. Assim, o termo se refere a qualquer elemento do ambiente que contribui para o tipo de interação que ocorre no momento observado. "Em qualquer interação envolvendo um agente com um outro sistema, as condições que permitem a interação incluem algumas propriedades do agente junto a algumas propriedades do outro sistema" (p. 338). Se pensarmos que a propriedade do sistema são as affordances, a propriedade do agente pode ser considerada a habilidade. A affordance apresenta as propriedades do sistema num processo de interação com um agente que traz consigo suas habilidades. A affordance é

\footnotetext{
${ }^{65}$ Tradução da autora, trecho original: "An important fact about the affordances of the environment is that they are in a sense objective, real, and physical, unlike values and meanings, which are often supposed to be subjective, phenomenal, and mental. But, actually, an affordance is neither an objective property nor a subjective property; or it is both if you like. An affordance cuts across the dichotomy of subjective-objective and helps us to understand its inadequacy. It is equally a fact of the environment and a fact of behavior. It is both physical and psychical, yet neither. An affordance points both ways, to the environment and to the observer."
} 
a potência, é uma pré-condição do sistema/objeto para a atividade, ou seja, a existência da affordance não obriga que a ação que ela pressupõe seja efetuada, mas a potência dela ocorrer está ali e precisa ser levada em conta quando abordamos as propriedades dos sistemas/objetos.

De acordo com Lievrouw (2014), as affordances possuem três características próprias: são funcionais, relacionais e aprendíveis. A qualidade de funcional se refere à possibilidade de permitir e restringir ações. Ser relacional está ligado ao fato de ligar atores humanos com o mundo dos objetos, e aprendível, quer dizer que o repertório de usos e possibilidades oferecido pelo artefato é criado e aumentado através da experiência e da relação entre atores humanos e não humanos. Segundo a autora, estas características estão ligadas diretamente a processos de mediação. "Affordances, em resumo, são oportunidades para ou convites para a ação que o objeto oferece aos atores" (LIEVROUW, 2014, p. 48) ${ }^{66}$.

Bloomfield et. al. (2010) estendem o conceito de affordances para incluir nele também os atributos não previstos inicialmente com o objeto. Os autores propõem que o conceito pode abarcar as trocas que estão em curso entre agentes e objetos/sistemas/dispositivos. Isso significa dizer que as affordances de um objeto são alteradas pela presença e interação com outros objetos ou agentes. Ou seja, além de levarmos em consideração que as propriedades específicas dos dispositivos móveis engendram hábitos e interações também específicas junto aos sujeitos, podemos também compreender que os artefatos podem também "ganhar" diferentes características à medida que entram em ação com outros objetos e sujeitos.

A materialidade do dispositivo/objeto/sistema com o qual se está interagindo é determinante para a compreensão do processo de interação, na medida em que ela engendra hábitos de consumo, de ação corporal, de cognição, além de práticas particulares de uso. Lemos (2012) problematiza o processo de leitura de um jornal em diferentes dispositivos como papel impresso, web, e-reader e tablet. O autor elenca inúmeras diferenças como postura de leitura, temporalidade, mobilidade do objeto, luz, preço, formatos multimídia, bancos de dados acessíveis, acessórios para interação, rapidez, conexão, coleção de exemplares, hipertextualidade etc. Todos esses aspectos diferem de um suporte para outro e alteram a experiência completamente. "Ao usar o

\footnotetext{
${ }^{66}$ Tradução da autora, trecho original: "Affordances, in short, are opportunities for or invitations to action that thing present to actors".
} 
acelerômetro (rodá-lo e colocá-lo na horizontal ou vertical) uma imagem pode se transformar em um vídeo. A tela tátil permite uma interação mais complexa e intuitiva do que aquela com o teclado para a web" (p. 122).

Um dispositivo móvel como o smartphone, por exemplo, tem a particularidade de ser um artefato para o consumo de conteúdos em situações que, na maioria das vezes, envolvem deslocamento, entretenimento momentâneo ou ainda a busca por informações específicas e/ou relacionadas à localização e, atualmente, em geral, são poucos os produtos jornalísticos que se utilizam dessas características para oferecer ao público conteúdo mais personalizado ou geolocalizado. Existe um imediatismo e um geolocalismo no consumo de informações, na medida em que, por exemplo, se o usuário enfrenta um problema no trânsito ele recorre ao seu dispositivo móvel para buscar informações sobre o assunto e também saber qual o melhor caminho para seguir a partir dali. Além disso, nesses artefatos, os conteúdos são acessados de forma privada, mas facilmente compartilhados de forma social através dos mesmos aparelhos, o que significa que os conteúdos precisam ser pensados dentro da possibilidade de replicação e redistribuição.

Aguado e Martínez (2008b) propõem caracterizar os dispositivos móveis digitais enquanto uma quarta tela incipiente de uso cotidiano para o consumo de conteúdo junto as outras três telas predominantes: PC, TV e cinema. Esta quarta tela personaliza e desloca as práticas tradicionais de consumo de conteúdo, segundo os autores. O seu crescimento junto aos usuários e sua valorização pelas empresas produtoras de conteúdo faz com que a percepção do telefone móvel enquanto algo além de um telefone predomine entre os usuários e os dispositivos se configurem num híbrido cultural e tecnológico dos "self-media", que seriam meios vinculados a identidade do usuário e que permitem a produção de conteúdos pessoais, atuam como meios conversacionais de interação e também meios tradicionais.

Os dispositivos móveis digitais, como smartphones e tablets, possuem uma lógica própria de funcionamento. Se na década de 1990, o jornalismo precisou compreender o funcionamento da lógica da internet e do consumo de informações através do computador pessoal para poder se renovar e atender às novas demandas, agora, esse mesmo jornalismo também precisa enxergar um modelo de consumo e produção diferente. Da mesma forma como não se aplicava transpor o conteúdo do impresso para os sites de jornais online, não se aplica também aos artefatos móveis a transposição 
desse conteúdo e dos comportamentos de leitura derivados das publicações anteriores. "Os dispositivos digitais, por exemplo, exigem o aprendizado das suas interfaces e protocolos. Por esta razão terminam produzindo, em longo prazo, modificações na produção e nos hábitos de trabalho dos seus usuários” (HOLANDA, 2014, p. 56).

[...] vemos como estas empresas se concentraram em conteúdos predominantemente adaptados ou reestruturados, que supõem um menor esforço de elaboração e uma menor necessidade de repensar suas estruturas produtivas. Os conteúdos com características específicas ou melhoradas - que aproveitam as vantagens da tecnologia móvel - têm sido minoritários, ainda que se admita que nos últimos tempos se pode perceber um maior interesse por desenvolver estes formatos (CASTELLET; FEIJÓO, 2013, p. 35) ${ }^{67}$.

Pellanda (2007) coloca que a personalização do consumo de informações é um dos principais aspectos inovadores que surge na mudança do modelo de mídia massiva para a rede móvel digital. Além disso, outro efeito visualizado é a potencialização do potencial interativo entre conteúdo, artefato e usuário. Os dispositivos móveis aparecem definidos nesse ponto como "computadores hiper-pessoais", pois, enquanto o desktop era compartilhado como um computador familiar, o smartphone é de uso extremamente pessoal e particular.

Aqui é importante fazermos uma diferenciação das ideias de personalização e customização. Camargo e Vidotti (2009) esclarecem que a customização está, normalmente, relacionada à aparência da interface que é visualizada pelo usuário, enquanto a personalização, geralmente, diz respeito às preferências do usuário com relação ao conteúdo. Ou seja, customização pode ser a possibilidade de trocar a cor do fundo da tela, aumentar o tamanho da fonte, trocar a fonte do texto, já a personalização é a opção por informações de temas e editorias específicas, recebimento de newsletter ou ainda o oferecimento por parte do serviço de conteúdos específicos relacionados aos hábitos de leitura do usuário. As autoras ainda esclarecem que a personalização pode demandar a coleta de dados do usuário, que é potencializada nos dispositivos móveis digitais na medida em que estes funcionam também como sensores. Sendo assim, para ampliar a oferta de personalização, os serviços podem captar dados como hábitos de

\footnotetext{
67 Tradução da autora, trecho original: “[...] vemos cómo estas empresas se han concentrado en contenidos predominantemente adaptados o replanteados, que suponen un menor esfuerzo de elaboración y una menor necesidad de repensar sus estructuras productivas. Los contenidos con características específicas o aumentadas -que aprovechan las ventajas de la tecnología móvil- han sido minoritarios, aunque hay que recetar que en los últimos tiempos sí puede percibirse un mayor interés por desarrollar estos formatos".
} 
consumo, padrões de compartilhamento, domínio de assuntos, tarefas e ambientes, frequência de uso, contexto econômico e geográfico, entre outros.

Scolari et al. (2009) defendem que, de acordo com o estudo dos meios, as plataformas móveis devem ser consideradas novos meios, onde a produção de conteúdo, o consumo e os modelos de negócio seguem uma lógica específica e diferente. Como exemplo disso é possível citar questões como: a permanência de contato dos sujeitos com os dispositivos móveis, na medida em que se está permanentemente junto a esse aparelho; e o fato de que esses artefatos são aparelhos pessoais que estão diretamente conectados à identidade do sujeito e ao seu movimento de consumo e também localização física, ou seja, há uma conectividade contínua e uma funcionalidade ligada ao contexto do usuário.

Nesse processo, a experiência de acesso ou interação com a informação tem cada vez mais dinamicidade. Os aspectos técnicos próprios dos dispositivos móveis proporcionam a tactilidade (característica de ser tátil, controlável com mãos e dedos) ao usuário o que faz com que o design digital precise se adaptar a essas condicionantes tecnológicas, visuais e estéticas, além de levar em consideração questões como arquitetura de informação e usabilidade.

Palacios e Cunha (2012) defendem que a tactilidade seja considerada uma característica dos espaços de informação jornalística na internet que ganha importância com o surgimento dos dispositivos móveis digitais, como tablets e smartphones. Segundo os autores, este novo tipo de interface se difere das interfaces gráficas porque possui a possibilidade de mudar suas propriedades mecânicas, gerando trocas bidirecionais entre sistema e usuário.

[...] a tactilidade já nasce plenamente apropriável para utilizações em aplicativos criados para plataformas móveis. Seu uso não está limitado por barreiras técnicas, mas apenas circunscrito pela capacidade criativa para um melhor aproveitamento. Em última instância, trata-se, como é de praxe cada vez que uma nova mídia ou - neste caso - um novo recurso midiático surge, de criar/aperfeiçoar os softwares e dispositivos que tirem melhor proveito das potencialidades oferecidas (PALACIOS; CUNHA, 2012, p. 671).

Os autores propõem também uma tipologia de ações possíveis de operacionalização da tactilidade divididas entre duas categorias. Na categoria de gestos, estão os movimentos possíveis dos dedos sobre a tela e suas diferentes ações resultantes (toque, duplo toque, rolar, deslizar, pinçar, pressionar, rotacional, deslizar com dois 
dedos ou mais, espalhar, comprimir). Na categoria sensores, estão as especificidades dos dispositivos que permitem o reconhecimento de ações do usuário e uma resposta direta a elas (girar, movimentar, vibrar). Apesar de proporem uma conexão destas potencialidades com os produtos jornalísticos, os autores afirmam que a exploração destes recursos ainda é pequena dentro desta indústria, deixando espaço aberto para experimentações mais efetivas. "O fato é que - por agora - a tactilidade apenas engatinha no jornalismo de tablets e smartphones e quase tudo está por ser feito" (PALACIOS; CUNHA, 2012, p. 682).

Saffer (2009) considera gesto qualquer movimento físico que um sistema digital pode perceber e responder sem a necessidade de um intermediário como, por exemplo, o mouse. Um abano, um aceno com a cabeça, uma batida de mãos ou pés, ou ainda o levantar de uma sobrancelha podem ser considerados gestos para o autor. Ele explica que, atualmente, a maioria das interfaces gestuais que possuímos é ou interfaces táteis ou "free-form". As interfaces táteis requerem que o usuário toque diretamente o dispositivo o que, segundo Saffer, limita a quantidade de gestos possíveis e o tipo de gestos também. Nas interfaces "free-form", o usuário não precisa tocar em nada e o usa o corpo como controle do sistema.

\begin{abstract}
Nós entramos numa nova era do design de interação. Nos últimos quarenta anos, nós permanecemos usando os mesmos paradigmas de interação humanocomputador que foram desenhados por Doug Engelbart, Alan Kay, Tim Mott, Larry Tesler e outros na Xerox PARC nos anos 1960 e 1970. Cortar e colar. Salvar. Janelas. A metáfora do desktop. E muitos outros que nós nem mesmo pensamos sobre quando trabalhamos em nossos dispositivos digitais. Estas convenções de interação irão permanecer, é claro, mas elas também serão complementadas por muitas outras que se aproveitam de todo corpo humano, dos sensores, de novos dispositivos de acesso e do crescente poder de processamento (SAFFER, 2009, p. 23) ${ }^{68}$.
\end{abstract}

Norman e Nielsen (2010) afirmam que ainda há muito espaço para evolução em se tratando de design de interfaces gestuais. Segundo os autores, há problemas nas questões de visibilidade, feedback, consistência, clareza, escala e confiabilidade. Na visibilidade, Norman e Nielsen apontam que é comum que, dentro do mesmo aplicativo,

\footnotetext{
${ }^{68}$ Tradução da autora, trecho original: "We've entered a new era of interaction design. For the past 40 years, we have been using the same human-computer interaction paradigms that were designed by the likes of Doug Engelbart, Alan Kay, Tim Mott, Larry Tesler, and others at Xerox PARC in the 1960s and 1970s. Cut and paste. Save. Windows. The desktop metaphor. And so many others that we now don't even think about when working on our digital devices. These interaction conventions will continue, of course, but they will also be supplemented by many others that take advantage of the whole human body, of sensors, of new input devices, and of increased processing power".
} 
uma ação tenha um resultado numa tela e outro tipo de resultado em outra. Por exemplo, se o deslizar para a direita exclui um e-mail numa tela do aplicativo do correio eletrônico, é preciso que a ação de deslizar para a direita seja o padrão para exclusão de mensagens e por isso, em todas as outras telas, ela precisa ter o mesmo resultado.

A categoria de feedback, para Nielsen, quer dizer que o sistema sempre precisa responder às ações do usuário, ou seja, o sujeito precisa receber do sistema uma indicação da ação que está realizando na interface, a fim de que confirme que está no caminho do resultado desejado. Para os autores, no entanto, isto não ocorre, por exemplo, com o botão de "voltar" padrão dos dispositivos que utilizam o sistema operacional Android. Ao tocar o botão voltar múltiplas vezes, o resultado final é que o usuário é enviado para a tela inicial do sistema, saindo do aplicativo onde estava, sem receber, entretanto, um feedback de que o último toque o faria receber este resultado.

Mais um problema é a falta de consistência nas ações possíveis dentro de diferentes aplicativos, indicando que os mesmos gestos são capazes de gerar múltiplos resultados diferentes, de acordo com a vontade do designer que construiu cada um dos serviços que se está usando. Segundo os autores, este tipo de atitude enfraquece a principal forma pela qual os usuários aprendem comportamentos: vendo o comportamento de outros usuários. Farman (2012) também reforça esse aspecto afirmando que as interfaces dos dispositivos móveis digitais são um conjunto de relações e estas relações são habituais, ou seja, a interface está diretamente conectada às experiências corpóreas habituais dos usuários e com isso, as relações que são estabelecidas estão ligadas às práticas e hábitos engendrados no consumo.

Outra diferença entre interfaces feitas para desktops e interfaces feitas para smartphones é que, nas primeiras, havia sempre um menu disponível a partir do qual o usuário poderia saber quais são as opções de navegação hipertextual disponíveis, nas segundas, no entanto, o uso de menus ainda oferece um resultado confuso, fazendo com que, na maioria das vezes, os usuários não saibam quais ações sequenciais realizar para seguir a leitura. Também num comparativo com desktops, Norman e Nielsen (2010) comentam a dificuldade de escalar o conteúdo para telas pequenas e grandes, na medida em que os gestos possíveis numa, nem sempre são possíveis, ou fáceis, na outra.

Ainda na questão da adaptação para telas pequenas, os autores comentam sobre a confiabilidade. Numa tela do computador pessoal, normalmente temos o ponteiro do mouse que nos indica por onde estamos navegando ou ainda onde estamos clicando. Nas 
interfaces gestuais, os gestos são invisíveis na tela, logo, o sistema precisa prover confiança ao usuário para que ele não cometa erros tão facilmente, ou então, para que ele saiba que é fácil ter uma ação de retorno (desfazer) no caso de realizar alguma ação indesejada.

\begin{abstract}
Sistemas gestuais requerem métodos inovadores de interação. Na verdade, esta é uma de suas virtudes: nós podemos usar o corpo. Nós podemos inclinar e balançar, girar e tocar, cutucar e sondar. Os resultados podem ser extremamente efetivos ao mesmo tempo em que transmitem uma sensação de prazer e diversão. No entanto, esses estilos de interação ainda estão em sua infância, fazendo com que seja natural esperar por grandes estudos e explorações que ainda precisam ser feitos. [...] As novas telas prometem revolucionar nossa mídia: notícias e artigos de opinião podem ser dinâmicos, com pequenos vídeos em vez de fotografias estáticas, imagens ajustáveis e manipuláveis em vez de diagramas estáticos. A Consumer Reports poderia publicar suas tabelas de classificação com pesos controlados pelo leitor, de modo que cada visualizador teria um conjunto personalizado de recomendações com base em resultados de teste padronizados. Os novos dispositivos também são divertidos de usar: gestos adicionam um bem vindo sentimento de atividade aos outrora cansativos apontar e clicar (NORMAN; NIELSEN, 2010, s/p $)^{69}$.
\end{abstract}

Para Bertocchi (2014), formatar uma narrativa é construir a experiência que será vivenciada pelo usuário e que ganha substância na interface. O desenho dessa interface é o lugar onde o formato narrativo se substancializa, logo, para a autora, não se trata apenas de organizar a informação, mas de desenhar uma experiência de interação entre usuário e conteúdo, levando em consideração tanto as potencialidades narrativas do próprio texto quanto as potencialidades técnicas oferecidas pelo dispositivo e pelo acesso à rede. Para discutir esse aspecto, a autora faz um apanhado histórico da evolução dos estudos de Arquitetura de Informação a fim de chegar à definição mais atual dessa função que é a de Design de Experiência ou ainda User Experience Design (Design de Experiência do Usuário).

Segundo Morville e Rosenfeld (2007), que estão entre os primeiros autores a tratarem do tema da Arquitetura de Informação, é possível conceituar AI como o design estrutural de ambientes de informação compartilhada que envolve a combinação de

\footnotetext{
${ }^{69}$ Tradução da autora, trecho original: "Gestural systems do require novel interaction methods. Indeed, this is one of their virtues: we can use the body. We can tilt and shake, rotate and touch, poke and probe. The results can be extremely effective while also conveying a sense of fun and pleasure. But these interaction styles are still in their infancy, so it is only natural to expect that a great deal of exploration and study still needs to be done. [...] The new displays promises to revolutionize our media: news and opinion pieces can be dynamic, with short video instead of still photographs, adjustable, manipulatable figures instead of static diagrams. Consumer Reports could publish its rating tables with readercontrolled weights, so each viewer would have a tailored set of recommendations based upon standardized test results. The new devices are also fun to use: gestures add a welcome feeling of activity to the otherwise joyless ones of pointing and clicking".
} 
sistemas de organização, rotulação, busca e navegação em sites. Os autores a definem ainda como a arte e a ciência de formatar produtos e experiências de informação com base na usabilidade e "encontrabilidade" (tradução literal do termo findability, que significa a possibilidade de algo ser facilmente encontrado numa interface). Além disso, eles também afirmam que a disciplina é focada na prática de trazer princípios do design e arquitetura para o cenário digital.

Segundo o Information Architecture Institute ${ }^{70}$, Arquitetura de Informação consiste na arte e ciência de organizar e rotular sites, intranets, comunidades online e softwares para favorecer a usabilidade e a "encontrabilidade". Como se pode ver, ambas as definições foram criadas levando em conta as interfaces produzidas para computadores pessoais, ou desktops. Com o avanço do tempo e da tecnologia, foi preciso levar em conta os aplicativos móveis e as interfaces para tablets e smartphones, que apresentam maior complexidade e também um maior número de possibilidades interativas, tornando-se necessário ampliar o espectro de atuação do arquiteto de informação, trazendo a figura do designer de experiência, visão que integra a necessidade de arquitetar não só a informação enquanto conteúdo, mas o sistema como um todo.

Esse novo aspecto da AI leva em conta o atual contexto pervasivo e ubíquo da comunicação contemporânea. Nesse sentido, chama-se arquitetura de informação pervasiva aquela que é pensada para o momento atual em que a tecnologia, a mobilidade e a conexão estão constantemente presentes e inseridas no cotidiano das pessoas. Ao falar de pervasividade e ubiquidade quer-se dizer aqui que a informação e a conexão digital estão permanentemente presentes na vida das pessoas, fazendo parte do contexto contemporâneo da comunicação. Ou seja, ainda que se tente, é muito difícil fugir do contexto de conexão contínua e permanente, na medida em que se usam sistemas bancários conectados, máquinas de cartões de crédito, telas informativas conectadas no sistema viário, terminais de compra de vale transporte, televisão digital, além, obviamente, dos smartphones e tablets. Assim, informação e conexão estão presentes e integradas na vida dos sujeitos e sua utilização está ligada diretamente ao dispositivo utilizado e às características específicas deste, que direcionam o consumo e mobilizam diferentes tipos de interação.

\footnotetext{
${ }^{70}$ http://iainstitute.org
} 
Oliveira; Vidotti e Bentes (2015) explicam que os debates mais atuais relacionados à Arquitetura de Informação buscam conectar a disciplina aos problemas mais recentes relacionados à ubiquidade dos dispositivos tecnológicos. Neste sentido, a AI recebe das autoras o enfoque pervasivo, ligado à noção de computação ubíqua que já tratamos no Capítulo 3. Para desenvolver este enfoque, as autoras utilizam a metáfora de uma represa. Segundo elas, quando uma represa rompe e a água se espalha por todos os lugares que não eram ocupados por ela anteriormente, temos uma metáfora da natureza pervasiva da informação que no atual contexto se espalha também por todos os espaços, dispositivos e momentos.

A metáfora da ubiquidade está no rastro que a água deixa ao se espalhar. Quando toca algum lugar ou objeto a água molha e deixa ali uma camada de sua existência, assim também é a informação ubíqua, que se integra aos ambientes e artefatos. Uma terceira metáfora possível é a de responsividade. Ao espalhar-se e entrar em contato com objetos e lugares, a água será absorvida de diferentes modos, de acordo com o material e natureza dos objetos. A informação digital também é dependente da natureza dos objetos e, ao mesmo tempo em que penetra nos mais diversos artefatos, também se diferencia de acordo com o dispositivo no qual é visualizada.

\footnotetext{
Dependendo das características do dispositivo e da capacidade de seus ambientes de informação se moldarem ao contexto e à informação, os sujeitos poderão utilizar melhor a informação digital, fazendo pontes entre esses dispositivos e seus ambientes, mas também poderão não conseguir utilizar dispositivos não responsivos, assim como a água pode não penetrar objetos com maior grau de compactação e dureza (OLIVEIRA; VIDOTTI; BENTES, 2015, p. 76).
}

A partir das metáforas, as autoras concluem que a arquitetura de informação pervasiva integra ambientes, espaços, lugares, pessoas e dispositivos fazendo com que a conexão e os aparatos se tornem invisíveis aos usuários, ou seja, tão integrados que suas presenças já sejam dadas como naturais e permanentes. Resmini e Rossati (2011) apresentam um conjunto de circunstâncias que ao longo do desenvolvimento da tecnologia fizeram com que se chegasse à ideia de arquitetura de informação pervasiva. Este conjunto apresentado pelos autores traz uma série de elementos e conceitos que já foram tratados ao longo do trabalho, funcionando como uma espécie de confirmação e união dos debates que vinham sendo empreendidos até aqui. São eles: 
a) arquitetura como ecossistema: nenhum artefato pode ser considerado isolado no sistema, mas sim integrante de um conjunto inter-relacionado que entrega uma experiência ao usuário;

b) usuário como mediador: os sujeitos redistribuem e coproduzem os conteúdos que circulam pelos ecossistemas comunicacionais;

c) conteúdo dinâmico: o conteúdo não acaba, permanece dinamicamente em evolução;

d) conteúdo híbrido: não se trata mais de uma notícia publicada em seu formato tradicional e nele se encerrando, mas de um conjunto híbrido de ambientes e mídias em relacionamento;

e) desenho de experiência: a construção da interface vai além da organização visual de elementos, mas leva em conta o trabalho de diferentes sistemas para entregar uma experiência específica ao usuário;

f) consumo multiplataformas: o usuário entra em contato com diversos elementos de forma ubíqua e cross-media.

Como explica Burgos (2013), o ambiente pervasivo faz com que os conteúdos precisem transitar por interfaces responsivas de tablets e celulares, dispositivos wearables ou vestíveis (como relógios inteligentes ou produtos que estejam ligados à lógica da Internet das coisas), carros conectados, vitrines, entre outros. Isso quer dizer que a informação transita em sistemas midiáticos híbridos que estão sendo utilizados por consumidores mais participativos e envolvidos no processo de produção, consumo e distribuição.

\footnotetext{
Este redesenho demanda novos layouts de interfaces com objetivos de relacionar: diferentes medidas antropométricas e resoluções de telas; variados contextos de uso de um mesmo dispositivo; o emprego de ferramentas de navegação mistas entre os sistemas operacionais e apps de produtividade, imersão e utilidade; a necessidade de circulação de dados online e offline em navegadores móveis e softwares aplicativos, bem como o emprego de restrições para o uso de linguagens que resultam em alto consumo de baterias, como Ajax e Javascript (BURGOS, 2013, p. 322).
}

Esses dispositivos requerem o desenho de narrativas que levem em consideração o caráter pervasivo e ubíquo da comunicação e atuem de forma contínua e sistemática, 
"sem ponto de origem e término estáticos e definitivos, prontas para novas formatações e desformatações, e inclusive deformações, com designs distintos em diferentes telas, sem estruturas fixas" (BERTOCCHI, 2014, p.73). O designer de experiência é um dos responsáveis por organizar o desenho do formato narrativo sistêmico, e aqui se utiliza o termo desenho para abarcar a construção da narrativa como um todo, levando em consideração todos os sistemas envolvidos e ampliando a ideia para além do design da interface gráfica. Por desenho tem-se uma noção mais ampla do que somente a diagramação do produto, mas sim a construção de uma interface que leve em conta aspectos de interação, sistemas, usabilidade e potencialidades específicas dos dispositivos móveis e da rede de conexão.

Para Saffer (2009), o design de qualquer produto ou serviço deve sempre partir das necessidades dos usuários, implicadas com as restrições do ambiente, da tec nologia, de recursos e objetivos da organização. Apesar desse conjunto, o sucesso do desenho de uma plataforma, normalmente, está diretamente ligado ao atendimento das necessidades de quem a usa, se isso não ocorrer, as chances de o serviço ser deixado de lado são bastante grandes. O autor estabelece alguns aspectos que são necessários para o bom design de interfaces gestuais, alguns bastante semelhantes aos de Norman e Nielsen (2010), são eles: affordances detectáveis, confiabilidade, feedback, adequação, significado, perspicácia, inteligência e ludicidade.

Affordances detectáveis quer dizer que o usuário precisa olhar para o objeto e entender o que deve fazer com ele, seu tipo de interação, as ações que estão sendo propostas a partir das affordances ali presentes. Confiabilidade quer dizer que a interface precisa ser confiável, ou ainda, precisa oferecer ao usuário a garantia de que ele não está caindo em alguma armadilha ao utilizá-la. Feedback está relacionado à convenção de determina que o usuário sempre precisa receber uma resposta ou uma indicação sobre o que está realizando naquele momento, a fim de que possa ter garantias de que está no caminho desejado. Adequação significa que os gestos propostos precisam ser adequados aos usuários para quem se está projetando a interface ou o dispositivo, sem construir barreiras inesperadas ou situações que possam causar constrangimento. Significado e perspicácia querem dizer que o sistema precisa ser significativo para quem o usa, ou do contrário, não será adotado, além disso, ele também precisa ser perspicaz ao oferecer-se para realizar tarefas que normalmente são difíceis ou custosas aos usuários. Inteligência e ludicidade querem dizer que o serviço precisa preencher as necessidades 
dos usuários de forma agradável e também mostrar-se acessível, a fim de que o sujeito se engaje na descoberta de novas possibilidades de interação. Quanto mais difícil for de realizar um gesto ou quanto mais complexa for a interação numa interface, mais penoso será para que os usuários se engajem no serviço e consequentemente, poucos irão adotar o sistema.

Rowland et al. (2017) afirmam que o design de experiência do usuário nasceu num mundo dominado pela computação pessoal, ou seja, pelos computadores de mesa, conhecidos como desktop. No entanto, a experiência do usuário mudou completamente a partir do momento em que as interações passaram a ocorre mais por smartphones, tablets, e-readers e televisões conectadas. Os profissionais ainda desenvolvem o que poderiam ser as melhores práticas de design para estes novos dispositivos, especialmente levando em consideração que as interações ocorrem numa variedade muito grande de contextos. Outro desafio que surge para os designers são os dispositivos ligados à internet das coisas que muitas vezes não possuem uma tela para a interação com o usuário (os assistentes pessoais Alexa e Google Home, mencionados no capítulo anterior, são acessíveis somente pela voz do usuário). Além disso, segundo os autores, estes dispositivos têm a característica de interagirem com muitos objetos ao mesmo tempo, o que precisa ser também levado em conta na hora de desenhar a experiência para eles. "Muitos produtos hoje são parte de um grande ecossistema de produtos e serviços, por isso os designers precisam considerar todas as partes deste ecossistema à medida que mapeiam como várias camadas habilitam ou restringem umas as outras" (CHANG; KING, 2015, s/p) ${ }^{71}$.

Haugen (2013) propõe uma série de elementos que diferenciam as características de aplicativos para dispositivos móveis digitais dos produtos que são criados para computadores pessoais. Inicialmente, ele aponta a diferença mais evidente que é o tamanho da tela. No computador pessoal, o espaço para apresentação de conteúdos é muito maior, além disso, os conteúdos são acessados pelo software navegador o que faz com que o design da informação seja independente do sistema operacional do aparelho. Nos smartphones, por exemplo, a realidade é bastante diferente, pois os produtos precisam se adaptar não somente ao sistema operacional que está sendo utilizado (Android, iOS, Windows), como também aos múltiplos e diferentes tamanhos de tela

\footnotetext{
${ }^{71}$ Tradução da autora, trecho original: "Many products today are part of a larger ecosystem of products and services, so designers should consider all parts of that ecosystem as they map out how various layers enable and constrain each other".
} 
disponíveis no mercado. Com isso, a quantidade de informação exibida é, normalmente, dividida em pedaços menores, além de possuir uma lógica de navegação diferente da que é pensada para a tela do desktop.

Isso nos leva à questão da interação nos dispositivos móveis digitais. Os padrões de interação dos smartphones são bastante diferentes daqueles que ocorrem num PC, normalmente controlado por um teclado e um mouse. O telefone é controlado com as mãos, utilizando uma interface táctil, além disso, o teclado do smartphone é muito menor, fazendo com que ações que demandam a digitação de muitas palavras se tornem mais onerosas aos usuários. Outra facilidade que o mouse oferece é a possibilidade de colocar o ponteiro em cima de alguma informação da tela e descobrir mais dados sobre o que pode ser acessado a partir dali. Este tipo de funcionalidade, costumeiramente chamado de "hover" ou "mouse-over" (flutuar, pairar, em tradução literal), não existe quando a tela é controlada com o dedo, fazendo com que seja necessário criar um outro tipo de interação que ofereça ao usuário estas mesmas informações ${ }^{72}$.

A interface táctil, no entanto, também traz vantagens nas suas formas de interação como, por exemplo, a interação direta com o elemento da tela, gestos, toques e ações que são disparadas a partir do movimento do dispositivo (girar a tela, ligar a câmera ou a lanterna, mostrar as horas etc.). Um exemplo ocorre quando o telefone está em alguma superfície, começa a tocar e a ação de virar a tela para baixo faz com que a ligação seja rejeitada automaticamente. Além disso, alguns dos smartphones mais atuais são capazes, inclusive, de responder a comandos de voz sem a necessidade de serem ativados com o toque da mão. Os telefones com os sistemas operacionais Android mais atuais são capazes de compreender a frase "OK Google" e a partir daí executarem ações solicitadas oralmente pelo usuário. Os modelos de iPhone 7 também já dispensaram a necessidade de tocar qualquer botão para ativar a assistente pessoal Siri.

Uma das diferenças mais essenciais e óbvias entre smartphones e computadores pessoais é a mobilidade, ou seja, a facilidade de carregar o dispositivo consigo ao longo de todo dia sem dificuldades. Ainda que seja possível fazer isso com um notebook, por exemplo, a facilidade com um aparelho de cinco polegadas e 200 gramas ainda é bem maior. A facilidade, no entanto, não é o principal aspecto da mobilidade, mas sim as possibilidades que ela traz consigo. Já mencionamos no capítulo anterior a diferença

\footnotetext{
${ }^{72}$ Para conhecer todos os padrões de interação e gestos utilizados em interfaces gestuais ver Saffer (2009).
} 
entre a mobilidade dos dispositivos móveis digitais e aquela que possuíamos em outros suportes, todavia, vale destacar que, em se tratando de interações, esta característica traz possibilidades como: acesso à localização do usuário com exatidão, acesso por parte do usuário a localizações de outros usuários, conexão ubíqua (embora mais custosa do que a conexão residencial), consumo de informações praticamente contínuo e inin terrupto (o usuário pode receber notificações de conteúdo 24 horas por dia), uso da câmera como escâner de códigos e $Q R$ Codes, entre outros.

\subsection{Características do formato do jornalismo ubíquo em smartphones}

Aguado e Castellet (2013) fazem um histórico da inserção do jornalismo nos dispositivos móveis digitais. No princípio, quando os telefones celulares não eram considerados smartphones e a conexão ainda era precária, o conteúdo era enviado aos usuários basicamente a partir de mensagens de texto (SMS) ou, quando mais evoluídos os aparelhos, mensagens multimídia (MMS) que continham algum tipo de imagem. Posteriormente, com a chegada dos primeiros "telefones inteligentes" como, por exemplo, os primeiros BlackBerry, o conteúdo já podia ser acessado em portais WAP. Alguns jornais também chegaram a ser distribuídos via e-readers como o Kindle, da Amazon, onde era possível visualizar o jornal de forma idêntica à versão impressa. Embora não tenham sido os precursores do mercado, foi a chegada do iPhone, telefone inteligente da Apple, em 2007, e do iPad, tablet da mesma empresa, em 2010, que transformou de vez o mercado em função da estética inovadora, da tela táctil e da plataforma de venda de aplicativos.

Pellanda (2016) localiza sete fases de desenvolvimento do jornalismo relacionadas à mobilidade (o autor utiliza o termo jornalismo móvel para se referir a este momento). São elas: 1) SMS; 2) WAP; 3) Web Móvel; 4) iPhone e Web Apps; 5) Notificações móveis e Apps; 6) Wearables; e, 7) Inteligência artificial e assistentes pessoais. $\mathrm{O}$ autor afirma que os caminhos de expansão atuais se localizam nas fases 6 e 7, sendo representados principalmente pelos relógios inteligentes e pelos assistentes pessoais que já operam nos smartphones. Segundo ele, o fato de o usuário receber alertas primeiro pelo smartwatch pode significar que este será o caminho para o envio de notícias de última hora, ampliando a característica de conexão ininterrupta do jornalismo contemporâneo. Pellanda também fala sobre a internet das coisas e o quanto 
a expansão deste tipo de dispositivo pode significar que teremos outras formas de transmitir informação como, por exemplo, pela cor dos dispositivos.

Desde o surgimento dos dispositivos móveis digitais, as empresas jornalísticas já criam produtos para serem distribuídos a partir deles o que, no entanto, não quer dizer que estes produtos sejam desenhados especificamente para estes artefatos e suas características. "Todavia, o conflito entre papel e internet como paradigmas, respectivamente, do portátil e do estático, não é, no fundo, um conflito de suportes: é, antes que isso, um conflito de formatos, de formas de entender o consumo de informação e a relação com o leitor" (AGUADO; CASTELLET, 2013, p. 191) ${ }^{73}$.

Aguado e Castellet (2013) ressaltam a linguagem de programação HTML5, desenvolvida a partir de 2008, como um ponto importante para o desenvolvimento de produtos destinados aos dispositivos móveis digitais. Segundo eles, inicialmente os produtos jornalísticos desenvolvidos para smartphones eram centrados na compressão do conteúdo, gerando uma navegabilidade restrita, no entanto, após a chegada dos tablets, buscou-se mais fortemente a possibilidade de desenvolver produtos melhor formatados, onde o visual e a qualidade fossem protagonistas na experiência do usuário. Muitos jornais adotaram o HTML5 como uma possibilidade de desenvolver aplicativos que pudessem chegar aos smartphones fora do círculo fechado das lojas de aplicativos. No Brasil, um desses exemplos é a Folha de São Paulo, que desenvolveu este tipo de aplicativo em 2011, onde os usuários podiam "salvar" um atalho para o site do jornal na tela inicial do telefone e a partir daí acessar os conteúdos atualizados ${ }^{74}$.

Aguado e Castellet destacam algumas características específicas dos aplicativos nativos para smartphones e dos baseados na web, feitos em HMTL5. Entre os pontos positivos dos apps estão: controle da experiência do usuário, integração ao hardware, segurança, estabilidade e integração com o sistema operacional. Como aspectos negativos estão: custo, complexidade, processo de aprovação, métricas e pouco controle de visibilidade. Como pontos positivos para o HTML5 estão: custo mais baixo, sem

\footnotetext{
73 Tradução da autora, trecho original: "Sin embargo, el conflicto entre el papel e internet como paradigmas, respectivamente, de lo portable y lo estático, no es, en el fondo, un conflicto de soportes: es, antes que eso, un conflicto de formatos, de formas de entender el consumo de información y la relación con el lector".

${ }^{74}$ As lojas de aplicativos recebem críticas de algumas empresas jornalísticas porque ficam com uma parte do lucro (normalmente 30\%) obtido pelas empresas com a venda de exemplares idênticos ao jornal impresso. As controladoras também restringem dados de acesso, métricas e controle sobre publicidade. Além disso, para ser aceito no sistema, o aplicativo precisa passar pelo crivo da empresa criadora do dispositivo. Atualmente, o aplicativo da Folha de São Paulo ainda é feito em HTML5, mas é distribuído pelas lojas de aplicativos.
} 
processo de aprovação, controle de métricas e controle de visibilidade. Entre os aspectos negativos estão: pior experiência do usuário, pior integração ao hardware e pouca integração ao sistema operacional. Os autores afirmam que, em termos gerais, os aplicativos nativos são capazes de oferecer uma experiência mais rica e de melhor qualidade aos usuários, incluindo sua capacidade de se integrarem melhor ao hardware do dispositivo e, consequentemente, às potencialidades do artefato. Por estarmos em consonância ao pensamento de Aguado e Castellet é que optamos neste trabalho por analisar os aplicativos para smartphone de quatro marcas jornalísticas de legado ${ }^{75}$. Neste sentido, as características que apresentamos aqui estão ligadas ao uso de aplicativos jornalísticos e não de websites em versão para dispositivos móveis digitais.

Após a apresentação do conceito de narrativa sistêmica e dos elementos que a diferenciam e complexificam no ambiente ubíquo, buscamos apresentar um conjunto de oito categorias que podem ser consideradas como características do formato da narrativa sistêmica no jornalismo ubíquo oferecido em aplicativos para smartphones. Chegamos a este conjunto de elementos a partir da leitura de múltiplos autores que compõem a base de sustentação deste trabalho (SAFFER, 2009; BERTOCCHI, 2014, 2016; RAMOS, 2011; RESMINI e ROSSATI, 2011; BURGOS, 2013; LEMOS, 2012, PALACIOS e CUNHA, 2012; SILVEIRA, 2016a, 2016b; GARRETT, 2011; NORMAN e NIELSEN, 2010). São elas:

a) geolocalização: identificação da localização geográfica do usuário e uso deste tipo de informação para oferecer conteúdo contextualizado. Falar em mobilidade, compressão da noção de espaço-tempo, não significa que o lugar não tenha mais importância dentro do consumo de conteúdo. Muito pelo contrário, "os lugares importam, e muito" na medida em que a experiência é construída dentro de um contexto local, um pertencimento que funda um espaço de memória e experiência. "Mesmo com os dispositivos móveis e os fenômenos de deslocalização e multilocalização, não há apagamento ou perda de sentido dos lugares. Toda comunicação será balizada por presenças em jogos territoriais” (LEMOS, 2009, p. 32). É possível dizer que a mobilidade dá

\footnotetext{
${ }^{75}$ Utilizamos o termo marcas jornalísticas de legado em consonância à expressão em inglês "legacy media" que se refere a empresas que possuem presença digital, mas construíram suas marcas, credibilidade e solidez em outros tipos de plataformas.
} 
maior importância ao lugar na medida em que ele é determinante para o contexto de conexão e informação. Se o sujeito utiliza o celular dentro do metrô para descobrir a causa do atraso do trem, por exemplo, é porque o local que ele ocupa naquele momento e o contexto de sua conexão - transporte público, deslocamento para outro endereço, divisão de espaço com outras pessoas - são determinantes para o consumo de informação. "É na tensão entre vários territórios (limites, bordas) que um ponto do espaço ganha atributos próprios (sociais, culturais, históricos) e torna-se um lugar. Este deve ser pensado como resultante de fluxos de territorialidades, incluindo agora a nova territorialidade informacional" (idem, p. 32). Assim, temos aqui mais um aspecto que corrobora a noção de espaços híbridos, na medida em que o lugar físico é determinante para o tipo de interação que o sujeito terá com o dispositivo móvel e com os conteúdos aos quais terá acesso a partir dele. Espaços físico e digital são indissociáveis neste novo contexto móvel, não há um ciberespaço para o qual nos transportamos e também não há a necessidade de estar num local físico específico e estático para que ocorra o acesso e a conexão;

b) conexão entre dispositivos: uso da capacidade do dispositivo de se vincular a outros artefatos conectados à rede de qualquer natureza (smartphones, tablets, carros, relógios, geladeiras etc.) para enriquecimento do conteúdo. Como já dissemos anteriormente, os dispositivos móveis digitais não atuam somente como artefatos para consumo de conteúdo, mas também como sensores capazes de capturar diversas informações sobre o contexto de uso e enviar estes dados para outros sistemas conectados. Normalmente, os dispositivos realizam este tipo de tarefa de forma autônoma, sem interação humana, numa ação que se dá entre objetos actantes. Incluir este aspecto nos serviços oferecidos por aplicativos jornalísticos pode automatizar o envio de vários tipos de informação relacionados aos objetos com os quais o smartphone está entrando em contato automaticamente. Por exemplo, se a minha geladeira é capaz de avisar ao meu telefone quais itens da minha lista de supermercado 
estão faltando, o aplicativo pode ser capaz de me enviar conteúdos sobre saúde e alimentação que estejam relacionados ao que eu estou consumindo ${ }^{76}$;

c) navegação em camadas: apresentação do conteúdo com diferentes níveis de profundidade, oferecendo ao leitor a possibilidade de aprofundamento na informação de acordo com a sua vontade, necessidade e contexto. Apesar de se referirem à arquitetura de conteúdo para a web, alguns autores apresentam aspectos relevantes a serem considerados também na hora de formatar notícias para os smartphones. Lowrey e Choi ${ }^{77}$ (2006, apud Canavilhas, 2014) afirmam que as notícias precisam atender tanto quem procura uma informação específica e tem um caminho próprio de leitura, quanto os usuários que necessitam ser guiados pelo sistema. Um modelo de design de navegação que faz sentido para os dispositivos móveis digitais é o modelo multilinear arbóreo apresentado por Salaverría (2005). Segundo ele, a notícia é composta por vários blocos de informação interconectados por links, sendo que cada bloco por ter múltiplos links para vários outros blocos subsequentes. Canavilhas (2005) apresenta um modelo bastante semelhante, mas com uma hierarquização dos blocos por níveis de importância e profundidade no texto, sendo o primeiro nível a unidade base, o segundo o nível de explicação, o terceiro, o de contextualização, e os seguintes, níveis de exploração. Outro modelo que se demonstra ainda mais adequado para os smartphones é o de Paul Bradshaw (2007), intitulado "The News Diamond" em função de sua forma semelhante a de um diamante. Neste modelo, o autor organiza a informação em fluxo, onde uma sequência de blocos de informação é produzida de acordo com o nível de profundidade e interesse do leitor. O primeiro bloco é composto de um alerta para a notícia, com poucas informações e links que podem levar o leitor a níveis mais profundos. Em seguida, viria uma espécie de rascunho da notícia, seguido do artigo completo

\footnotetext{
${ }^{76}$ Não apenas este aspecto, mas vários outros abordados neste trabalho levantam a discussão acerca da privacidade e segurança dos dados dos usuários. É importante ressaltar que nenhum dos usos que se propõe destes dados neste trabalho é feito sem a consideração de que todos demandam autorização e concordância do usuário, além de demandarem também sistemas de segurança próprios para que vazamentos ou invasões a estes bancos de dados sejam evitados. Esta discussão, embora extremamente importante e frutífera, não é tema deste trabalho e, por questões de tempo e espaço, não está contida em nosso espectro de ação e objetivos.

${ }^{77}$ LOWREY, W; CHOI, J. The News Story and Cognitive Flexibility. In: XINGEN, Li. Internet users: the making of a mainstream medium. New Jersey: Lawrence Erlbaum, 2006.
} 
num nível abaixo e sequencialmente, análises, reflexões e contextualizações para o leitor mais interessado. Como já dissemos anteriormente, o leitor que está consumindo conteúdo num smartphone possui características específicas de contexto, onde este provavelmente se dá num momento rápido ou de trânsito entre um lugar e outro. Sendo assim, o conteúdo precisa ser apresentado de uma forma que permita ao leitor ter uma ideia do que está sendo noticiado com opções de ignorar o material, seguir a leitura ou aprofundar-se efetivamente no tema, todas elas em formatos adequados ao dispositivo móvel digital;

d) personalização e fluxo de conteúdo: oferecimento ao usuário da possibilidade de definir quais conteúdos quer receber e quando, ou ainda, uso de algoritmos para construção de perfis dos leitores, levando em consideração seu hábitos e preferências, ou ainda, envio de informação curada por editores humanos de acordo com o perfil do usuário. Essa funcionalidade também inclui a capacidade de armazenar conteúdos já vistos pelo usuário e consequentemente não repeti-los, ou ainda, habilidade de oferecer leitura offline e programada. Outro elemento que pode ser visto nesta personalização potencializada é o envio de notificações a partir da autorização do usuário levando em consideração o contexto do leitor e também suas preferências e hábitos de consumo;

e) redistribuição: facilitação da possibilidade de compartilhar conteúdos com outros aplicativos sem necessariamente precisar sair do primeiro. A característica do usuário ativo de atuar diretamente na redistribuição de conteúdos e no caminho que a narrativa percorre depois de sua visualização na interface é crucial no jornalismo contemporâneo. Respeitar esse protagonismo do usuário é fundamental e facilitar este papel que ele exerce também, neste sentido, os aplicativos precisam facilitar o compartilhamento de seus conteúdos a partir do próprio serviço, sem que seja necessário que o leitor copie um link, saia do aplicativo jornalístico, abra um segundo aplicativo, cole o link copiado numa mensagem e aí sim envie o conteúdo para seus contatos. Este trajeto precisa ser realizado diretamente dentro do primeiro app, de forma facilitada e com a garantia de que o conteúdo terá uma boa adaptação ao 
serviço que está sendo conectado. Isso garante a perpetuação da narrativa enquanto sistema circular e mutante;

f) contextualização: o aplicativo é capaz de compreender o contexto do usuário, tanto de localização, quanto de momento de uso e com isso envia informações ligadas à interação pontual que está ocorrendo. Em 2015, o Google apresentou um estudo ${ }^{78}$ sobre o que convencionou chamar de micromomentos. De acordo com o documento que congrega dados de pesquisas realizadas pela empresa com usuários de smartphones, as pessoas checam seus telefones em média 150 vezes ao dia, sendo que $68 \%$ faz isso pelo menos nos 15 minutos iniciais do dia depois que acorda. O estudo indica que os smartphones ativam novas formas de realizar tarefas cotidianas e também de aprendizado. Os números apresentados no relatório indicam que os usuários gastam em média 177 minutos do dia no telefone e este período, normalmente, se divide em sessões de um minuto e dez segundos. Esses pequenos intervalos de uso congregam diversos tipos de ações: enviar uma mensagem, postar uma foto, ligar para um amigo, checar o e-mail e as redes sociais, entre outros. O que a empresa chama de micromomentos são os intervalos nos quais os usuários podem ser sensibilizados para alguma mensagem específica de uma marca. Não são todos os intervalos de um minuto e dez segundos, na medida em que nem sempre o usuário quer ter sua atenção desviada da atividade que está sendo realizada. Os micromomentos são os intervalos nos quais o usuário se volta para o dispositivo para realizar uma ação relacionada com algo que ele precisa ou quer naquele momento. Esses momentos, divididos em "eu quero saber", "eu quero ir", "eu quero comprar" e "eu quero fazer", são compostos por intenção, contexto e imediatismo. Embora o documento elaborado pelo Google seja bastante direcionado para conversões de compra, os dados e as considerações não deixam de valer para o jornalismo contemporâneo na medida em que este, dentro do smartphone, compete com todos os outros serviços que ali estão. Se a empresa deseja que o usuário abra o meu aplicativo de notícias e se engaje com a minha marca jornalística, ela precisa conquistar a sua atenção e o seu micromomento, demonstrando capacidade de ser relevante no contexto do

\footnotetext{
${ }^{78} \mathrm{https}$ ://think.storage.googleapis.com/images/micromoments-guide-to-winning-shift-to-mobiledownload.pdf
} 
usuário. A pesquisa realizada pelo Google indica três boas práticas para chegar aos usuários em seus intervalos de uso do smartphone, são elas: 1) Presença (antecipe os micromomentos e esteja visível e presente para o instante em que eles ocorrerem); 2) Utilidade (seja relevante para as necessidades dos usuários); e, 3) Rapidez (seja rápido e ágil, pois o intervalo de uso é muito pequeno);

g) integração ao sistema: o aplicativo é capaz de se integrar ao sistema operacional e oferecer conteúdo e serviços ao usuário sem que ele precise buscar o app em sua tela inicial, incluindo aí interações por voz e por gestos, oferecendo uma interface mais conversacional para o usuário. Teixeira (2015) explica que uma das principais tendências no design de experiências de usuário é deixar de pensar somente na interface quando se tratam de serviços oferecidos para o smartphone. Segundo ele, uma das primeiras ações que são tomadas pelas pessoas ao pegar o telefone na mão é conferir as suas notificações, ou ainda, quando estas são recebidas acabam virando justamente o motivo para que a pessoa volte sua atenção para o celular. Neste sentido, já não importa somente a interface do aplicativo em si, mas o conteúdo e as notificações que partem deste serviço. "Você não precisa de uma interface maravilhosa para ver a previsão do tempo. Você precisa é ser avisado 5 minutos antes de começar a chover" (s/p). Os sistemas operacionais e suas interfaces estão se tornando cada vez mais pró-ativas, significando que são capazes de executar tarefas pelo usuário a partir da detecção de ações realizadas por ele como: ida para o trabalho, compra de uma passagem de avião, chegada em casa etc. Alguns aplicativos já seguem esta tendência, o WhatsApp, por exemplo, permite que o usuário visualize as mensagens por notificação e também que ele responda às mensagens sem precisar acessar o aplicativo e parar o que está fazendo no smartphone;

h) boa usabilidade: o produto é intuitivo, oferece feedback ao usuário de suas ações, não necessita de instruções de uso e respeita as heurísticas tradicionais de usabilidade. Nielsen (1995) estabeleceu dez heurísticas de usabilidade para o design de interfaces que se tornaram clássicas nos estudos de arquitetura de informação, webdesign e experiência do usuário. Apresentamos o conjunto a seguir: 
- visibilidade do status do sistema: o sistema precisa sempre manter os usuários informados sobre as ações que estão sendo realizadas através de feedback em tempo adequado;

- adequação ao contexto: o sistema precisa utilizar linguagem adequada ao usuário, com conceitos e frases familiares ao código que é compartilhado pelos consumidores naturalmente;

- controle e liberdade do usuário: é preciso oferecer saídas fáceis e rápidas aos usuários que eventualmente escolherem alguma opção errada dentro do sistema;

- consistência e padrão: as interações propostas pelo aplicativo precisam seguir um padrão e uma consistência, normalmente seguindo convenções já sólidas no design de interface;

- prevenção de erros: o sistema precisa ter um design cuidadoso que previna os usuários de cometerem erros em suas interações, para isso é preciso eliminar condições que possam favorecer o erro ou oferecer mensagens de confirmação para a ação;

- reconhecimento: o usuário não pode ser forçado a lembrar de algo dentro do sistema; opções, objetos e ações precisam estar visíveis e acessíveis;

- flexibilidade: o sistema precisa servir tanto ao usuário experiente quanto ao novato; para o primeiro é importante oferecer atalhos, para o segundo, informações claras;

- minimalismo: tudo que está numa interface precisa ser útil e relevante; não há espaço para dados e ações irrelevantes;

- ajuda: mensagens de erro precisam ser claras e sempre oferecer uma opção para resolução do problema;

- documentação: o ideal é que o sistema seja fácil o suficiente para ser usado sem um manual, no entanto, se este for necessário, ele precisa estar visível, ser claro e conciso. 
A reunião e apresentação desses aspectos relacionados ao formato da narrativa sistêmica no jornalismo ubíquo nos remetem à nossa segunda hipótese de pesquisa (H2). Aqui podemos perceber que a união do conceito de jornalismo ubíquo e suas respectivas categorias aos preceitos da narrativa sistêmica nos levam à identificação de elementos específicos constituintes do formato do jornalismo ubíquo, tanto no desenvolvimento dos códigos e sistemas tecnológicos dos produtos nos quais a narrativa é renderizada quanto nos desenhos de interface e navegação.

São esses aspectos que norteiam - em conjunto a outros - a análise empírica desta pesquisa. Quer-se observar de que forma quatro dos principais jornais do mundo (The New York Times, The Guardian, El País e O Estado de S. Paulo) estão levando em consideração essas questões, como as estão trabalhando e, principalmente, se as estão implantando em seus produtos jornalísticos. Nosso instrumento de observação para os aplicativos é mais bem explicitado no capitulo seguinte, o qual é composto pela junção das características citadas acima com as categorias do jornalismo ubíquo e também com elementos de análise de design que são expostos a seguir. 


\section{ANÁLISES}

O objetivo deste capítulo é apresentar a finalização de nosso estudo. Enquanto pesquisa aplicada, que visa um conhecimento referenciado à realidade empírica, trazemos nesta parte a instância técnica que é posterior à adesão ao quadro teórico de referência do trabalho. A finalidade, aqui, é realizar a operação de causação (LOPES, 2001), que tem como meta traçar conexões entre as teses que foram expostas nos capítulos anteriores e os fatos que foram coletados junto aos aplicativos das empresas analisadas e, também, durante entrevistas com os editores responsáveis pelas marcas.

Um dos instrumentos que utilizamos para realizar a nossa instância técnica consiste numa tabela de análise. Esta tabela surge da união dos elementos que caracterizam o jornalismo ubíquo, aliada às categorias do formato narrativo sistêmico no jornalismo ubíquo. Além disso, também construímos um instrumento que se une à tabela inicial para avaliar aspectos da usabilidade e do design dos aplicativos jornalísticos para smartphones. Como já explicitamos anteriormente, nossa instância técnica é composta pela observação de quatro aplicativos para smartphone de jornais de referência nacional e internacional The New York Times, The Guardian, El País e O Estado de S. Paulo (Estadão). A justificativa para a escolha dessas marcas em específico foi apresentada no item 2.3 do trabalho. Também como já dito, realizamos entrevistas (semiestruturadas e in loco) com editores de todas as marcas que fazem parte da nossa amostra selecionada. As entrevistas não são método para obtenção da resposta à pergunta principal desta pesquisa, mas foram realizadas com o objetivo de qualificar e enriquecer a análise dos dados.

No próximo item deste capítulo apresentamos os nossos instrumentos de observação dos aplicativos para smartphone das marcas selecionadas. Em seguida, trazemos as análises detalhadas para cada uma das empresas em conjunto com dados que consideramos relevantes, obtidos através das entrevistas realizadas com profissionais das marcas pesquisadas. Ao final, apresentamos uma análise de comparação entre todas as marcas que fazem parte deste estudo. 


\subsection{Instrumentos de observação}

Como já dissemos anteriormente, nosso instrumento de observação e análise empírica desta pesquisa nasce a partir de nosso referencial bibliográfico. Nosso primeiro instrumento é composto pela união das características que foram organizadas nos capítulos anteriores em relação ao jornalismo ubíquo (item 3.5) e às características do formato da narrativa sistêmica para smartphones (item 4.3) dentro desse conceito de jornalismo.

\section{Quadro 1 - Propriedades do Jornalismo Ubíquo}

\begin{tabular}{|c|c|}
\hline (1) & $\begin{array}{l}\text { paço híbrido: o JU está inserido no contexto de interface social, onde os } \\
\text { odutos são capazes de afetar o comportamento dos usuários em trânsito. }\end{array}$ \\
\hline (2) & $\begin{array}{l}\text { Legado potencializado: o JU congrega e potencializa as seis características } \\
\text { estabelecidas para o webjornalismo: hipertextualidade, interatividade, } \\
\text { multimidialidade, personalização, atualização contínua e memória. }\end{array}$ \\
\hline (3) & $\begin{array}{l}\text { JDBD: o JU também reúne as funcionalidades e categorias do Jornalismo Digital } \\
\text { em Base de Dados. }\end{array}$ \\
\hline (4) & $\begin{array}{l}\text { Multisuporte: o JU integra múltiplas plataformas e dispositivos, tendo um } \\
\text { conteúdo circulando e não finito. }\end{array}$ \\
\hline (5) & $\begin{array}{l}\text { Contextualidade: o JU leva em consideração o contexto de consumo do usuário e } \\
\text { se adapta de acordo com o momento de consumo. }\end{array}$ \\
\hline (6) & $\begin{array}{l}\text { Integração: assim como os dispositivos móveis digitais e a conexão ubíqua, o JU } \\
\text { "desaparece" no cotidiano do usuário e se integra ao seu padrão de consumo. }\end{array}$ \\
\hline (7) & $\begin{array}{l}\text { Continuidade: o JU ocorre } 24 \text { horas por dia, } 7 \text { dias por semana, permanentemente } \\
\text { disponível. }\end{array}$ \\
\hline (8) & Automação: o JU usa algoritmos e opera em conjunto à inteligência artificial. \\
\hline (9) & $\begin{array}{l}\text { Formato ubíquo: o JU se diferencia a partir de formatos narrativos inovadores e } \\
\text { imersivos com o uso de realidade virtual, por exemplo. }\end{array}$ \\
\hline (10) & $\begin{array}{l}\text { Redistribuição e re-produção: enquanto serviço e produto diretamente } \\
\text { relacionado à ubiquidade, o JU favorece a produção de conteúdo pelo público e } \\
\text { também a distribuição de outros conteúdos a partir dos usuários. }\end{array}$ \\
\hline (11) & $\begin{array}{l}\text { Personalização bidirecional: no JU, tanto o usuário pode personalizar seu } \\
\text { conteúdo, quanto o produto pode construir um perfil do leitor e personalizar a } \\
\text { entrega a partir disso. }\end{array}$ \\
\hline (12) & $\begin{array}{l}\text { Redação mobile first: com a ascensão crescente dos dispositivos móveis digitais, } \\
\text { as empresas jornalísticas transformam suas redações para operar dentro da lógica } \\
\text { desses artefatos. }\end{array}$ \\
\hline (13) & $\begin{array}{l}\text { Multicompetências: tanto a diversidade de profissionais envolvidos na produção } \\
\text { jornalística cresce dentro do JU, quanto à multiplicidade de competências que } \\
\text { passam a fazer parte do perfil profissional do próprio jornalista. }\end{array}$ \\
\hline
\end{tabular}


Quadro 2 - Propriedades do formato narrativo sistêmico para smartphones no JU

\begin{tabular}{|c|l|}
\hline (A) & $\begin{array}{l}\text { Geolocalização: identificação da localização do usuário e uso desta para o envio } \\
\text { de conteúdo. }\end{array}$ \\
\hline (B) & $\begin{array}{l}\text { Conexão entre dispositivos: vinculação do artefato com outros dispositivos com } \\
\text { ou sem interferência humana. }\end{array}$ \\
\hline (C) & $\begin{array}{l}\text { Navegação em camadas: apresentação do conteúdo em diferentes níveis de } \\
\text { profundidade. }\end{array}$ \\
\hline (D) & $\begin{array}{l}\text { Personalização e fluxo de conteúdo: definição das preferências de leitura tanto } \\
\text { por parte do usuário quanto por parte do serviço. }\end{array}$ \\
\hline (E) & $\begin{array}{l}\text { Redistribuição: facilidade de compartilhamento no conteúdo com outros } \\
\text { serviços. }\end{array}$ \\
\hline (F) & $\begin{array}{l}\text { Contextualização: o aplicativo é capaz de compreender o contexto de uso do } \\
\text { leitor e agir a partir desse conhecimento. }\end{array}$ \\
\hline (G) & $\begin{array}{l}\text { Integração ao sistema: o aplicativo se integra ao sistema operacional do } \\
\text { dispositivo facilitando o contato com seu conteúdo. }\end{array}$ \\
\hline (H) & $\begin{array}{l}\text { Boa usabilidade: o produto atende aos princípios de usabilidade estabelecidos } \\
\text { por Nielsen (1995). }\end{array}$ \\
\hline
\end{tabular}

Fonte: a autora

Como alguns itens dos dois quadros supracitados (1 e 2) se assemelham, para que não ocorressem repetições durante a análise dos objetos empíricos, decidimos construir um novo quadro que reunisse os dois, agrupando itens que possam ser analisados conjuntamente e também eliminando categorias, a fim de dar preferência à resolução do objetivo principal do trabalho que é a investigação acerca do formato narrativo para smartphones. Além disso, o último item $(\mathrm{H})$ do quadro 2, que apresenta os formatos narrativos sistêmicos para smartphones, "Boa usabilidade", é tema de um segundo instrumento de observação, exclusivo para observação de aspectos mais ligados ao design da narrativa, por isso, ele foi suprimido da união dos aspectos apresentados aqui. Vale ressaltar ainda que os itens 12 e 13 do quadro 1 não estão presentes em nosso instrumento de observação dos formatos narrativos nos aplicativos, mas fizeram parte de nossa sondagem realizada pessoalmente nas redações das empresas, por isso, aparecem em nossa análise subsequente, mas não na tabela. Sendo assim, nosso primeiro instrumento de observação dos aplicativos jornalísticos pesquisados pode ser visualizado no quadro a seguir. 
Quadro 3 - Categorias de análise do formato narrativo no Jornalismo Ubíquo (Instrumento 1 de observação)

\begin{tabular}{|c|c|c|}
\hline I & $(A)$ & Geolocalização \\
\hline II & $(B)+6$ & Conexão entre dispositivos / Integração \\
\hline III & $(C)$ & Navegação em camadas \\
\hline IV & $(D)+8+11$ & $\begin{array}{c}\text { Personalização e fluxo de conteúdos / Automação / } \\
\text { Personalização bidirecional }\end{array}$ \\
\hline V & $(E)+10$ & Redistribuição / Redistribuição e re-produção \\
\hline VI & $(F)+5$ & Contextualização / Contextualidade \\
\hline VII & $(G)$ & Integração ao sistema \\
\hline
\end{tabular}

Fonte: a autora

Após a apresentação de nosso primeiro instrumento de observação, é necessário que expliquemos a construção e fundamentação do segundo instrumento utilizado na análise de nosso objeto empírico, no qual objetivamos levar em consideração elementos mais conectados à usabilidade do aplicativo e do design de experiência deste. Para construção deste segundo instrumento, apoiamos-nos em autores que abordam temas como o design para dispositivos móveis digitais e também design de experiência do usuário. Um deles é Garret (2011) que propõe um modelo de visualização da construção de projetos digitais voltados à experiência do usuário. $\mathrm{O}$ objetivo do modelo, segundo o autor, é enfatizar que o processo de constituição de um produto ou serviço que leva em consideração a experiência do usuário, que não pode ocorrer sem a consciência de todas as etapas envolvidas no trabalho e também de todos os profissionais que se conectam a cada uma delas. O modelo de Garret é composto por cinco camadas: a superfície, o esqueleto, a estrutura, o escopo e a estratégia. Graficamente, o modelo se apresenta da seguinte forma (figura 5): 
Figura 5 - Elementos de projetos de experiência do usuário

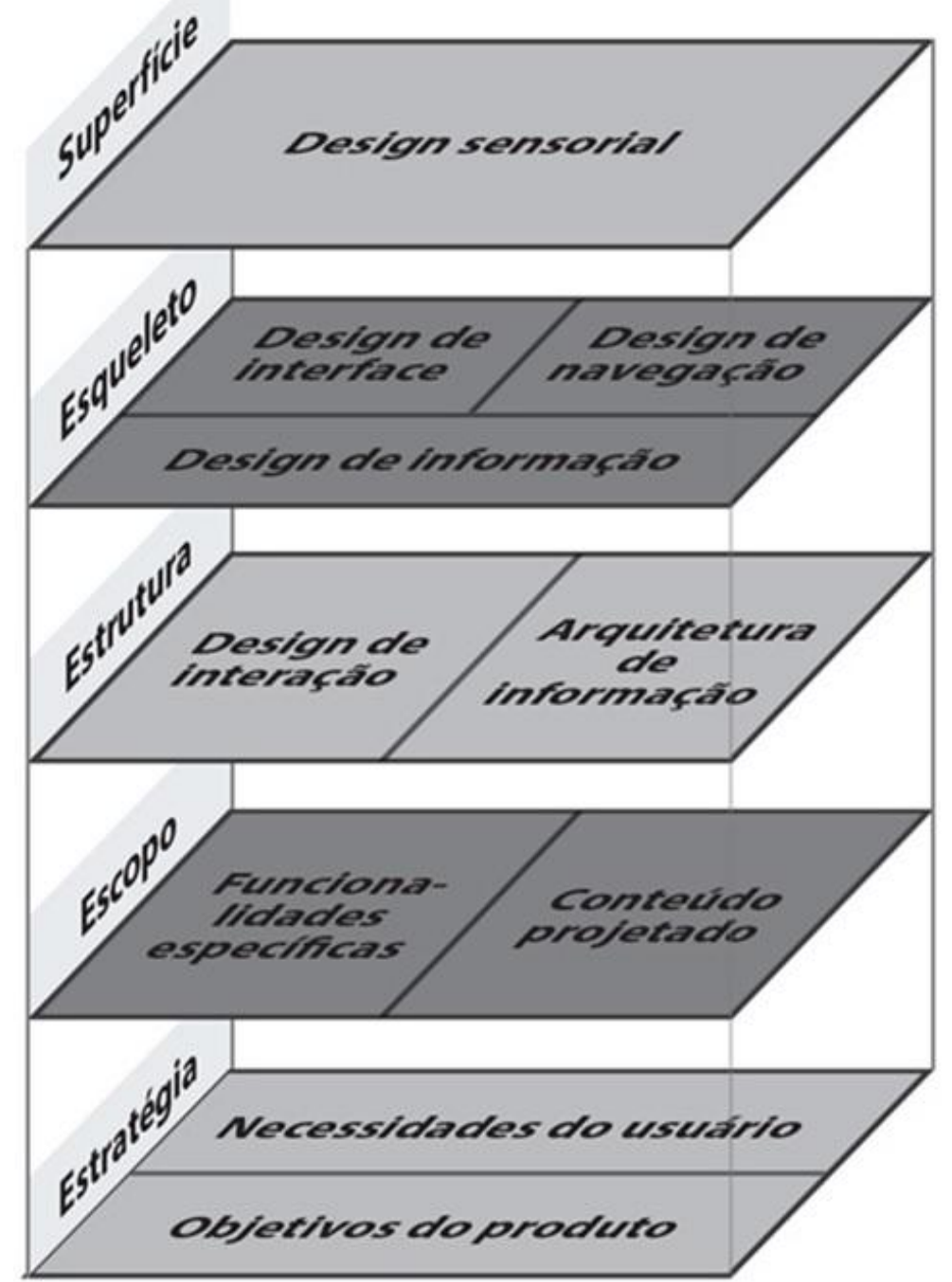

Fonte: Garret (2011)

A superfície é a parte visível do projeto, a interface que apresenta as informações levadas ao usuário. Abaixo dela está o esqueleto, que é desenhado para otimizar a localização e operação de botões, controles, blocos de imagem e texto, entre outros elementos, presentes na interface. Em seguida está a estrutura que, segundo Garret, é a forma abstrata do esqueleto. Enquanto esse último define como os elementos serão dispostos na interface, a estrutura define como o usuário chegará até o serviço e também como se relacionam cada um dos elementos que serão dispostos na tela e suas funções. Mais abaixo está o escopo que especifica quais serão as características do serviço e também que funções serão desempenhadas por cada uma delas. Por último, o plano da estratégia determina o escopo, a partir da incorporação tanto do objetivo da empresa que 
está construindo o produto digital quanto dos usuários que irão se apropriar desse serviço. Todos os planos são interdependentes e fundamentais para que se consiga chegar a um projeto desenhado visando à experiência do usuário. Garret esclarece que as decisões que são tomadas em cada um dos planos afetam diretamente as opções disponíveis no plano seguinte.

Cada plano é composto por alguns elementos-chave na construção do projeto, essa divisão torna mais fácil e visível a função de cada uma das camadas. No plano da estratégia estão as necessidades dos usuários e os objetivos do produto. No escopo, estão as funcionalidades específicas do serviço e o conteúdo que será projetado. Na estrutura, estão o design de interação e a arquitetura de informação do projeto, ou seja, onde se define como o sistema responde ao usuário e como os conteúdos serão organizados para facilitar a experiência do consumidor. No plano do esqueleto, estão o design de informação (semelhante à arquitetura de informação, mas com um passo além, onde se simula graficamente a posição dos conteúdos na tela), o design de interface (desenho da interface efetiva, propriamente dito), e o design de navegação (definição dos elementos que permitirão a navegação do usuário entre os conteúdos do sistema). No plano da superfície, está a experiência sensorial do usuário com o produto final, efetivamente.

Obviamente, como esclarece Garret, assim como todo modelo, esse também é uma redução e simplificação de como operam os elementos de um projeto que visa à experiência do usuário. Na prática, os planos se entrecruzam ou não têm limites tão claros e expressivos. Além disso, também é possível que outros elementos-chave e até mesmo outras camadas apareçam em projetos específicos. Para o foco deste trabalho, interessam-nos, mais especificamente, as camadas do esqueleto e da superfície na medida em que congregam mais elementos relacionados ao formato da narrativa sistêmica (embora todos os elementos e todas as camadas sejam interdependentes e acabem interferindo no processo como um todo).

Outra autora que também nos serve de fundamentação e apoio para a construção do segundo instrumento é Gruszynski (2016) que propõe, através de Garret, a construção de um instrumento de níveis de avaliação do papel do design na consolidação da identidade de veículos que nascem no impresso e se ramificam para plataformas digitais. A autora apresenta roteiros de avaliação de marcas jornalísticas para cada uma das camadas propostas por Garret (2011), no entanto, os modelos propostos por ela são 
bastante amplos e extensos por condensarem a análise de uma marca jornalística em multiplataformas: impressa, desktop e tablet.

Em função da extensão do roteiro (figura 6) proposto pela autora e também do fato de ele conter elementos que não interessam especificamente para o nosso objeto empírico, pois estão relacionados à tablets e sites mobile, utilizamos o modelo como fundamentação e inspiração para compor um novo instrumento adaptado a este trabalho. Unimos às propostas de Gruszynski (2016), algumas ideias de Palomo et al. (2011), como, por exemplo, posição e funcionamento da publicidade e dos elementos multimídia, para configurar uma sugestão mais compacta e adequada ao design narrativo para smartphones. 
No capítulo anterior, apresentamos as 10 heurísticas clássicas de Nielsen (1995) para a usabilidade, um trabalho, obviamente, relacionado à websites. Também apresentamos os elementos que Saffer (2009) considera necessários para se levar em conta no desenho de interfaces gestuais. Além disso, também trouxemos os principais erros e problemas encontrados em interfaces de dispositivos móveis digitais de acordo com Norman e Nielsen (2010). Esse conjunto de condições apresentadas pelos autores foi reunido e filtrado, a fim de conservar o essencial ao nosso objeto empírico e eliminar repetições. Apresentamos o resultado na lista a seguir:

a) affordances detectáveis: o usuário olha para o sistema e entende o que deve fazer com ele;

b) adequação e acessibilidade: os gestos propostos são adequados aos usuários para quem a interface foi projetada;

c) significado e perspicácia: o sistema é significativo para o usuário e perspicaz ao realizar tarefas complexas ou cansativas;

d) feedback: o sistema mantém os usuários informados sobre as ações que estão sendo realizadas;

e) consistência e padrão: as interações propostas pelo aplicativo têm padrão e consistência;

f) prevenção de problemas, confiabilidade e retorno: o sistema previne problemas, oferece mensagens de confirmação e alternativas rápidas de retorno;

g) reconhecimento: o usuário reconhece as opções existentes no sistema;

h) ajuda: mensagens de erro são claras e oferecem uma opções de resolução.

Outra proposta que também nos serve de fundamentação é a de Shitkova et al. (2015) que introduzem um conjunto de guias de usabilidade para aplicativos e sites desenvolvidos para dispositivos móveis. Os autores levam em consideração as heurísticas já tradicionais ligadas à usabilidade criadas por Nielsen, na década de 1990, e também suas atualizações propostas nos anos seguintes por vários autores. O conjunto de 39 guias, construído pelos autores, é dividido em cinco categorias: layout, navegação, design, conteúdo e performance. Em função de também ser um guia extenso e composto por categorias que não se encaixam perfeitamente nos objetivos deste trabalho, fizemos 
uma filtragem dos elementos apresentados no modelo e chegamos à seguinte relação de aspectos a serem considerados nesta pesquisa:

a) conteúdo posicionado na parte central da tela;

b) rolagem horizontal evitada;

c) conteúdo organizado verticalmente e sem uso de abas;

d) botão de login no topo da tela;

e) barra de busca visível e fácil de usar;

f) menus de navegação simples e fáceis de usar;

g) menus de navegação com um nível de profundidade;

h) rolagem e multiplicidade de opções no теnи evitadas;

i) opção fácil e rápida de retorno à tela inicial;

j) conteúdos clicáveis visíveis e destacados na tela;

k) ícones visíveis e identificáveis;

1) mantém a posição de leitura da tela quando o aplicativo é minimizado;

m) corrige automaticamente erros de digitação;

n) implementa feedback sensorial para as ações do usuário;

o) suporta os gestos clássicos para controle de aplicativos;

p) minimiza o tempo de carregamento e oferece rapidez.

Cabe ainda trazer como contribuição nesta área as ideias de Griffiths (2015) que é o autor de um estudo do Google sobre os princípios de UX para dispositivos móveis digitais. O material foi produzido a partir de uma seleção das melhores práticas de UX para aplicativos, da auditoria de apps na Europa, Oriente Médio, África e América do Norte; das linguagens visuais dos sistemas Android e iOS, além de outras pesquisas secundárias. O estudo é dividido em categorias como adoção, uso, transação, retorno e usabilidade, onde, dentro delas, o pesquisador detalha boas práticas que devem ser realizadas para que o usuário não perca o interesse no serviço. Expomos a seguir uma seleção das boas práticas apresentadas no estudo que servem a este trabalho: 
a) rapidez de carregamento inicial do aplicativo;

b) tela de abertura comunica a essência da marca e oferece funcionalidades prioritárias;

c) a ajuda condiz com a ação que o usuário está executando;

d) menu acessível em todos os níveis do aplicativo;

e) páginas longas oferecem, ao final, elementos que permitem ao usuário continuar navegando;

f) o login é fácil ou social (Facebook, Google, LinkedIn etc.), e não obrigatório;

g) o aplicativo solicita permissões, autorizações e explica os motivos para os pedidos;

h) as imagens podem ser deslizadas na horizontal;

i) há opções para escolher a qualidade do vídeo que será visualizado;

j) as notificações por push são configuráveis e também desativáveis;

k) o formulário se adapta ao tipo de informação que precisa ser preenchida (para campos de e-mail, a opção de @ fica visível; para campos de telefone, só o teclado numérico aparece etc.).

Após a exposição das contribuições de diversos autores com relação à análise do design de aplicativos para smartphone que nos servem de embasamento, podemos apresentar nosso segundo instrumento de observação dos objetos empíricos. Para sua construção utilizamos os subsídios de Garret (2011), Gruszynski (2016), Palomo et al. (2011), Shitkova et al. (2015), Saffer (2009), Norman e Nielsen (2010), Nielsen (1995), Resmini e Rosati (2011), Hartson e Pyla (2012), e Griffiths (2015). Apresentamos o instrumento a seguir em formato de quadro e dividido em duas categorias: design de navegação e design de interface. 
Quadro 4 - Categorias de análise da interface e navegação dos aplicativos

(Instrumento 2 de observação)

\begin{tabular}{|c|c|}
\hline & Design de Navegação \\
\hline 1 & Menus de navegação simples e fáceis de usar \\
\hline 2 & Opção rápida e fácil de retorno à tela inicial \\
\hline 3 & Posição de leitura na tela é mantida quando o aplicativo é minimizado \\
\hline 4 & Corrige automaticamente erros de digitação na busca \\
\hline 5 & Implementa feedback sensorial para as ações do usuário \\
\hline 6 & Suporta gestos clássicos para controle de aplicativos \\
\hline 7 & Minimiza o tempo de carregamento e oferece rapidez \\
\hline 8 & A ajuda condiz com a ação que o usuário está executando \\
\hline 9 & Menu acessível em todos os níveis do aplicativo \\
\hline 10 & $\begin{array}{l}\text { Páginas longas oferecem, ao final da rolagem, elementos que permitem ao usuário } \\
\text { continuar navegando }\end{array}$ \\
\hline 11 & O login é fácil ou social, e não obrigatório \\
\hline 12 & O aplicativo solicita permissões e explica as razões dos pedidos \\
\hline 13 & As interações propostas têm padrão e consistência \\
\hline 14 & $\begin{array}{l}\text { O sistema oferece mensagens de erros claras com opções de solução e retorno, } \\
\text { além de mensagens de confirmação }\end{array}$ \\
\hline \multirow[t]{2}{*}{15} & As opções existentes no sistema são reconhecíveis pelo usuário \\
\hline & Design de Interface \\
\hline 16 & Conteúdo posicionado na parte central da tela \\
\hline 17 & Conteúdo organizado verticalmente, sem uso de abas \\
\hline 18 & Botão de login e barra de busca no topo da tela \\
\hline 19 & Menus de navegação com um nível de profundidade \\
\hline 20 & Rolagem e multiplicidade de opções no menu evitadas \\
\hline 21 & Conteúdos clicáveis visíveis e destacados na tela \\
\hline 22 & Ícones visíveis e identificáveis \\
\hline 23 & $\begin{array}{l}\text { Tela de abertura comunica a essência da marca e oferece funcionalidades } \\
\text { prioritárias }\end{array}$ \\
\hline 24 & As imagens podem ser deslizadas na horizontal \\
\hline 25 & Há opções para escolher a qualidade do vídeo que será visualizado \\
\hline 26 & As notificações por push são configuráveis e também desativáveis \\
\hline 27 & Os formulários se adaptam ao tipo de informação preenchida \\
\hline 28 & A publicidade não é invasiva e pode ser fechada \\
\hline 29 & As fotos podem ser ampliadas \\
\hline 30 & A interface tem opções de acessibilidade \\
\hline
\end{tabular}


A partir desses dois instrumentos apresentados neste capítulo realizamos as análises dos aplicativos para smartphone das marcas jornalísticas que fazem parte de nosso objeto empírico. As análises são apresentadas separadamente por marca, a fim de dar a atenção e a profundidade necessárias a cada uma delas, além disso, ao final das observações de cada um dos produtos, apresentamos uma apreciação de níveis de adoção das características que fazem parte dos nossos instrumentos. Esta apreciação está dividida em três níveis: Implementado, Parcialmente implementado e Não implementado, tornando possível uma consideração acerca da posição em que se encontram as marcas analisadas com relação à utilização dos elementos característicos do Jornalismo Ubíquo e seus formatos narrativos.

\subsection{The New York Times}

O The New York Times é um jornal norte-americano fundado em 1851, com sua sede principal em Nova York. Dentro da indústria jornalística, ele é considerado um jornal de referência por ter características únicas que dificultam sua comparação a outros veículos, entre elas, o investimento financeiro da família que comanda a empresa Ochs-Sulzberger -, a capacidade de produção, e o perfil editorial. Na internet, o jornal é publicado desde 1996 já com produção de conteúdo específico para a plataforma. Em 2006, a empresa lançou seu site móvel (mobile.nytimes.com), voltado para os smartphones da época. Em 2008, nasceu o primeiro aplicativo do jornal para iPhones com o diferencial de oferecer conteúdo para leitura offline. Em 2011, o jornal implantou o paywall (traduzido, normalmente, como muro de pagamentos), sistema de acesso que limita a quantidade de artigos que podem ser lidos gratuitamente no veículo e oferece um tipo de assinatura digital para que os usuários tenham acesso total a todo o conteúdo. No mesmo ano, a empresa lançou um aplicativo para Windows Phone que foi atualizado na metade do ano seguinte. Em 2012, o jornal investiu num aplicativo para Android, exclusivo para a cobertura das eleições, além de atualizar a versão já existente para esse tipo de sistema operacional. A empresa também lançou, no mesmo ano, um app em HTML5 para iPad.

Em 2014, a empresa lançou um segundo aplicativo intitulado NYT Now para iPhones. A ideia desse app era oferecer aos leitores que não podiam dedicar muito tempo à leitura, uma curadoria de assuntos importantes ao longo do dia. Um dos 
diferencias do aplicativo era que o conteúdo oferecido não era, necessariamente, do jornal, sendo seu papel oferecer uma seleção confiável de textos e temas aos seus leitores. O aplicativo foi descontinuado em 2016, fazendo com que o jornal permanecesse somente com o app tradicional lançado há mais tempo e que dá acesso direto ao conteúdo produzido pelo veículo.

Em 2015, o New York Times lançou o aplicativo NYT VR que dá acesso, exclusivamente, aos conteúdos produzidos pelo jornal em realidade virtual. Durante a campanha de promoção do aplicativo, o jornal enviou gratuitamente a seus assinantes um Google Cardboard ${ }^{79}$ para ser utilizado com o smartphone para visualização das reportagens em realidade virtual. Conforme exposto por Pavlik (2014), os conteúdos imersivos, em realidade virtual, $360^{\circ}$, ou realidade aumentada são um dos formatos inovadores pertencentes ao que chamamos aqui de Jornalismo Ubíquo. Esse tipo de conteúdo vem recebendo atenção e investimento de diversas marcas jornalísticas. Dentre as abordadas neste trabalho, NYT, The Guardian e El País possuem aplicativos exclusivos para oferta e visualização desse tipo de produção. Embora não seja o nosso foco de análise nesta pesquisa, consideramos que a produção desse tipo de conteúdo é uma característica do direcionamento da marca jornalística à adoção das categorias do Jornalismo Ubíquo, pois se trata de um investimento num formato imersivo fortemente relacionado ao contexto contemporâneo.

Para esta análise, focamo-nos em observar o aplicativo tradicional do NYT em sua versão 6.06.1 (9814), visualizando a versão internacional do produto ao longo do mês de fevereiro de 2017. A observação foi realizada num smartphone da marca Motorola, modelo Moto G4 Plus, com tela Full HD 1080p (1920 x 1080) de 5,5 polegadas, processador octa-core Qualcomm Snapdragon 1,5 Ghz, memória RAM de $2 \mathrm{~Gb}$, armazenamento interno de $32 \mathrm{~Gb}$ e sistema operacional Android versão 6.0.1 Marshmallow. As condições de conexão se deram por acesso em rede sem fio residencial de fibra ótica $5 \mathrm{Ghz}$ com velocidade de $100 \mathrm{Mb} / \mathrm{s}$ de download e $50 \mathrm{Mb} / \mathrm{s}$ de upload ou, então, por acesso em rede móvel 4G. Todas as observações subsequentes de outras marcas jornalísticas também foram feitas sob essas condições. É importante

\footnotetext{
${ }^{79}$ Google Cardboard é um óculos de realidade virtual desenvolvido pelo Google para ser utilizado com o smartphone. O óculos é feito de papelão e é facilmente montado em casa pelo próprio usuário. As dobras permitem o encaixe o telefone à frente das lentes que permitem a visualização do conteúdo no formato esperado.
} 
pontuar nossas condições de observação, pois caso fossem diferentes poderiam, obviamente, gerar resultados distintos ${ }^{80}$.

Figura 7 - Tela inicial do aplicativo do NYT para smartphones Android

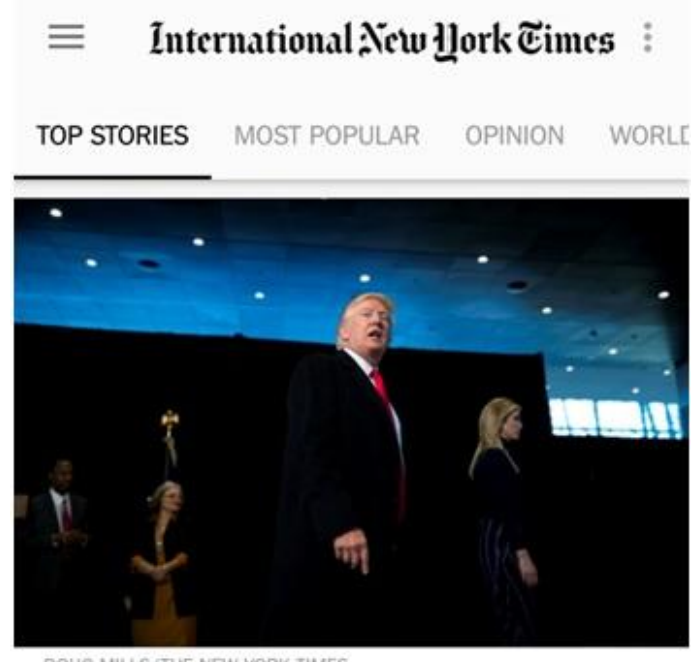

DOUG MILLS/THE NEW YORK TIMES

\section{Your Morning Briefing}

Here's what you need to know to start your day.

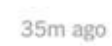

THE 45TH PRESIDENT

Fonte: ${ }^{81}$

Ao longo da observação aqui apresentada acerca do aplicativo do NYT também trazemos partes que consideramos relevantes da entrevista realizada com editores da empresa. Em maio de 2016, estivemos na sede do NYT em Nova York e conversamos com Alexandra Hardiman, então vice-presidente de Produto, Brian Hagman, diretor de Desenvolvimento de Novos Produtos Digitais, e Kate Harris, diretora de Produto com foco em parcerias com plataformas externas. Todas as entrevistas deste trabalho foram realizadas de forma semiestruturada.

Iniciando nossa observação pelos elementos do primeiro instrumento, o primeiro ponto que nos chama a atenção no aplicativo do NYT é o pequeno ou quase nulo uso de

80 Os aplicativos analisados também foram observados brevemente num iPhone 5C com sistema operacional $i O S$, onde não constatamos diferenças significativas entre estas versões dos apps e as que operam em sistema Android. Esta observação, no entanto, foi breve e sem o rigor científico empenhado na que apresentamos ao longo deste capítulo.

${ }^{81}$ Todas as imagens que compõem as análises deste trabalho são capturas da tela do smartphone onde foram realizadas as observações. 
recursos de geolocalização. O serviço não envia informações de uma forma precisa com relação a pontos específicos de localização do usuário. Brian Hagman esclarece que o uso de geolocalização na empresa se dá mais em relação ao fuso horário dos leitores. Por exemplo, o resumo matinal que o jornal envia diariamente para que as pessoas saibam os principais assuntos da manhã é recebido pelos usuários de acordo com o fuso horário no qual estão, isso porque, na costa oeste dos Estados Unidos, por exemplo, há uma diferença de tempo com relação a Nova York, o que faria com que os leitores daquela área recebessem o alerta ainda enquanto estão dormindo. "A maneira como usamos geolocalização está mais relacionada à como o conteúdo cabe na vida e no ritmo das pessoas do que o envio de conteúdo que está precisa e especificamente relacionado ao local onde elas estão no momento", explica. Algo que poderíamos explicar como uma espécie de "cronolocalização".

Além dessa possível opção editorial, Hagman explica também que o veículo não possui dados suficientemente ricos sobre os usuários para poder fazer esse tipo de entrega mais personalizada. Há alguns experimentos sendo realizados dentro do jornal, no entanto, o que é possível de ser feito com geolocalização no momento se resume a um nível nacional e não tão específico. O diretor também explica que há uma preocupação ética com relação ao uso que se faz das informações que são possíveis de serem obtidas a partir do dispositivo móvel digital. "É preciso pensar sobre a quantidade de dados que o usuário nos oferece e o quanto isso volta para ele em valor de conteúdo ou interação. Então é preciso saber que há tecnologia baseada em movimentos capaz de me informar cada vez que o usuário pega o telefone, no entanto, é preciso questionar como interagir a partir disso de uma forma que seja valiosa para o leitor”. Sendo assim, o serviço também não possui um nível avançado de contextualização com relação ao momento do leitor. O contexto ao qual o aplicativo se adapta ocorre somente com relação ao fuso horário do leitor e ao fato de ele estar desperto ou não para receber o resumo matinal de notícias (no final do dia, o aplicativo mostra um resumo de notícias da noite, entretanto, ele não é enviado como alerta, o usuário só o vê se acessa o app), o aplicativo não é capaz de detectar questões como estar em movimento ou pausa para alguma atividade específica.

Apesar disso, tanto Hagman quanto Hardiman destacam que a empresa vem trabalhando para oferecer cada vez mais níveis de personalização da experiência com o aplicativo para o usuário. Uma das possibilidades que era trabalhada naquele momento 
era a capacidade de detectar a língua que está sendo usada no dispositivo do usuário e, a partir disso, enviar conteúdo traduzido ou produzido naquela língua para o leitor. Além disso, os usuários que optam por receber o resumo matinal de notícias do NYT, o recebem de acordo com a localização: todos que estão fora dos Estados Unidos recebem a versão internacional do alerta.

A despeito dessas possibilidades, o aplicativo não utiliza algoritmos para detectar preferências de leitura do usuário ou ainda para construir um perfil do leitor e enviar alertas a partir disso. $\mathrm{O}$ aplicativo também não armazena que conteúdos já foram lidos pelo usuário para que não apareçam novamente na tela, ou então, para que sejam acompanhados no caso de interesse maior sobre o assunto. O que é possível fazer em termos de personalização do serviço, do lado do usuário, é: salvar textos para leitura offline; escolher as editorias das quais deseja receber alertas (são sete opções: notícias urgentes, reportagens especiais, resumo matinal, negócios e tecnologia, Nova York, política e esportes); alterar o tamanho do texto e o brilho da tela; customizar as editorias que aparecem no mепи superior; e, definir a qual edição se deseja ter acesso (Norteamericana, Internacional ou em Espanhol).

Figura 8 - Elementos de personalização e redistribuição no app do NYT

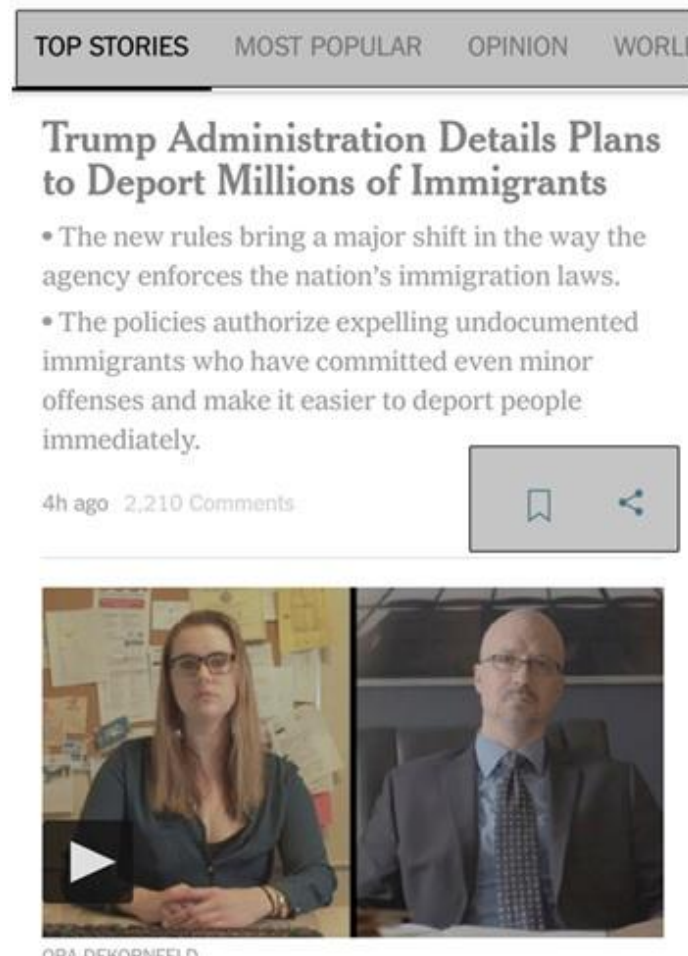

Watch: Taking On Trump's Travel Ban 
Na figura 8, acima, é possível ver sombreado o menu principal que pode ser personalizado com as editorias de preferência do usuário. É permitido visualizar até dez editorias nesse menu de acordo com a escolha do leitor. A navegação entre as editorias é feita através de rolagem horizontal e isso ocorre tanto quando se está na tela principal, quanto dentro de um artigo. Outro elemento sombreado abaixo à esquerda é o ícone para salvar conteúdos para leitura posterior offline. Ao lado direito dele está o ícone para compartilhamento da matéria com outros serviços. O aplicativo oferece ao usuário uma ampla gama de possibilidades de redistribuição dos conteúdos. Quando se clica no ícone para compartilhar aparecem diversos aplicativos instalados no dispositivo como Twitter, Facebook, Messenger, WhatsApp, Hangouts, Skype e Snapchat. Além disso, também é possível enviar o conteúdo por bluetooth e SMS e salvá-lo em serviços de armazenamento como Dropbox, Google Drive e Evernote. A mensagem compartilhada normalmente inclui o título do artigo e um link para o acesso que pode ser aberto tanto no navegador como no aplicativo se quem o recebeu o tiver instalado (ao tocar no link o sistema oferece a opção de escolha de onde se quer acessar o conteúdo). Ou seja, o serviço favorece a redistribuição dos seus conteúdos, mas não facilita algum tipo de intervenção do usuário diretamente no conteúdo. Uma característica que pode ser considerada uma pequena possibilidade de intervenção é a opção de compartilhar partes do texto que se está lendo, é possível selecionar uma parte do texto na tela e compartilhar somente aquele trecho através de serviços de terceiros.

O aplicativo também não favorece ou estimula a integração entre dispositivos, na medida em que não se conecta diretamente com outros artefatos sem a intervenção humana. Um exemplo de conexão é a possibilidade de enviar conteúdos via bluetooth, no entanto, isso só pode ser feito com a ação do leitor. Também a integração com o próprio sistema operacional do dispositivo não é aproveitada além da possibilidade de enviar notificações. Ao receber o alerta, o usuário precisa ser direcionado para o aplicativo para realizar a leitura do conteúdo, sem poder fazê-lo numa janela que não o tire da ação que está realizando naquele momento no dispositivo. Além disso, não há a possibilidade de uso de comandos de voz ou sensor de movimentos.

No aspecto da navegação em camadas, o aplicativo também não demonstra inovação na arquitetura dos conteúdos e na oferta de níveis de profundidade de leitura. $\mathrm{Na}$ tela inicial, as principais notícias são exibidas com pequenas chamadas adicionais à manchete principal, no entanto, o usuário não recebe outras opções de tamanho de 
conteúdo a ser consumido. Uma vez acessado o artigo, ele possui o mesmo tamanho e organização que está presente no site do jornal, reduzindo a possibilidade de aprofundamento ou contexto do tema aos links que ficam dispostos no meio do texto, repetindo, uma vez mais, o desenho de hipertextualidade tradicional da web, como pode ser visto na figura 9 , abaixo.

Figura 9 - Visão interna de um artigo aberto no aplicativo do NYT

\section{Got a confidential news tip?}

The New York Times would like to hear from readers who want to share messages and materials with our journalists.

\section{Learn More}

The directives would also instruct Immigration and Customs Enforcement, as well as Customs and Border Protection, the parent agency of the Border Patrol, to begin reviving a program that recruits local police officers and sheriff's deputies to help with deportation, effectively making them de facto immigration agents. The effort, called the $287(\mathrm{~g})$ program, was scaled back during the Obama administration.

The program faces resistance from many states and dozens of so-called sanctuary cities, which have refused to allow their law enforcement workers to help round up undocumented individuals.

Sendo assim, podemos ver na tabela 1 e no gráfico 1 , a seguir, um resumo da análise realizada com nosso primeiro instrumento. As categorias foram avaliadas a partir das condições "Implementada", "Parcialmente Implementada" e "Não implementada". 
Tabela 1 - Avaliação 1 do app do NYT

\begin{tabular}{c|c|c|c}
\hline & Implementada & $\begin{array}{c}\text { Parcialmente } \\
\text { Implementada }\end{array}$ & Não Implementada \\
\hline I & & $\mathrm{X}$ & $\mathrm{X}$ \\
\hline II & & & $\mathrm{X}$ \\
\hline III & & $\mathrm{X}$ & \\
\hline IV & $\mathrm{X}$ & $\mathrm{X}$ & \\
\hline V & & $\mathrm{X}$ & \\
\hline VI & & & \\
\hline VII & & &
\end{tabular}

Fonte: a autora

Gráfico 1 - Representação das categorias do JU no app do NYT

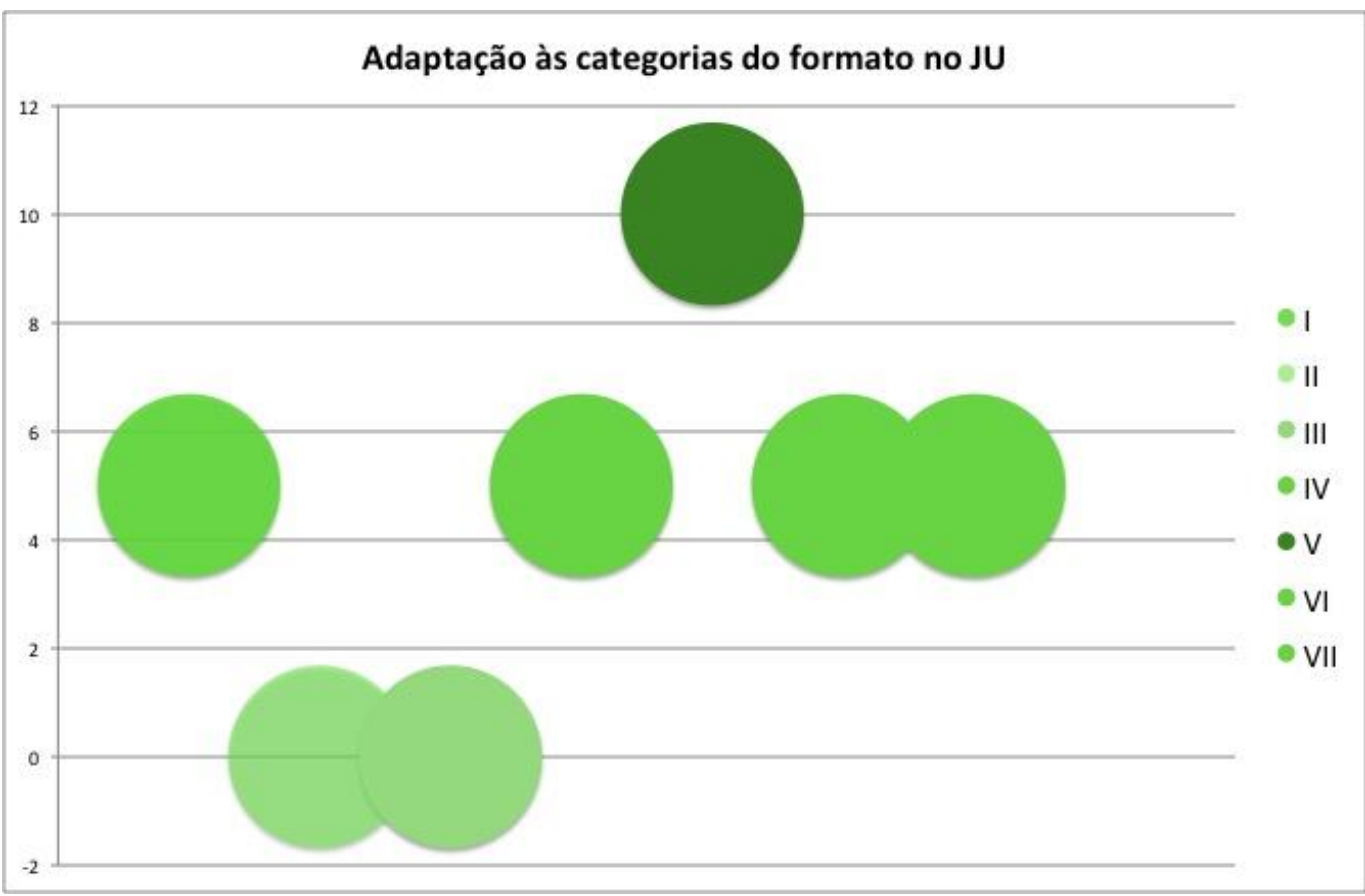

Fonte: a autora

Ao observar os dados acima (tabela 1, gráfico 1), podemos perceber que o aplicativo se encontra num momento de transição, onde as categorias relacionadas ao Jornalismo Ubíquo ainda estão parcialmente implementadas ou então, visivelmente não implementadas. Somente uma das categorias demonstrou-se capaz de ser considerada completamente implementada, a de redistribuição, o que fica mais bem visualizado no gráfico que representa esta avaliação. No eixo Y, as avaliações foram representadas a partir de números, sendo 10 para "Implementada", 5 para "Parcialmente implementada" 
e 0 para "Não implementada". Cada um dos círculos coloridos representa uma categoria, estando organizadas em ordem crescente a partir do eixo $\mathrm{X}$, como pode ser visualizado na legenda.

Uma categoria (14\%) está implementada e quatro se apresentam como parcialmente implementadas (57\%), ou seja, é possível perceber que a maioria das categorias permanece numa situação de transição ou possível evolução, o que pode significar que a empresa tem certa compreensão de quais elementos podem ser explorados dentro do jornalismo contemporâneo feito para dispositivos móveis digitais, no entanto, ainda não possui condições (sejam elas financeiras, de pessoal ou de tecnologia) para explorar totalmente as potencialidades latentes dos artefatos. O fato de a maioria das categorias se localizar numa condição parcial de implementação indica que ainda há um caminho considerável a ser percorrido, a fim de que todas as características cheguem a um total aproveitamento de seu potencial.

A diretora Alexandra Hardiman afirma que o NYT enxerga o móvel como um dos principais locais onde a audiência está e, consequentemente, onde ela deve ser engajada. Segundo ela, o jornal pesquisa como oferecer às pessoas não somente o conteúdo jornalístico na plataforma, mas também serviços que tornem o produto oferecido pelo jornal relevante e integrado na rotina e no cotidiano do leitor. Além disso, a empresa também busca oferecer cada vez mais conteúdos e serviços exclusivos aos assinantes do jornal, como forma de deixar claro o valor agregado à assinatura do veículo.

O NYT não tem uma redação exclusiva para a produção do conteúdo digital, dentro da redação tradicional há pessoas com cargos que são exclusivos para a área digital do jornal, no entanto, todos os produtores de conteúdos são motivados a produzir material para todos os canais, segundo o diretor Brian Hagman. Em 2014, ao contrário do movimento que marcou o começo da adaptação dos jornais à chegada da internet, em vez de ter um núcleo específico para o digital, o jornal criou uma área dentro da redação exclusiva para o produto impresso, onde trabalham editores responsáveis por adaptar o material que foi produzido para o digital e também em planejar e construir a edição impressa do dia seguinte. A criação de uma área exclusiva para o impresso é uma tendência que se mostra presente em outras marcas de nossa amostra empírica como é possível de ser constatado nos próximos itens do trabalho.

Além da redação, o jornal tem uma área chamada "Produto" onde atuam cerca de 30 profissionais divididos em três áreas: "News Products", "Data" e "Subscriber 
Experience". O primeiro grupo é responsável pelos produtos mais jornalísticos como o aplicativo principal da empresa, o segundo cuida de outros produtos como os aplicativos de receitas, vídeos e entretenimento, e o terceiro grupo é responsável por cuidar da experiência dos usuários, agindo tanto no back-end, quanto no front-end. Segundo Brian Hagman, a área de tecnologia do NYT responsável por bancos de dados, sistemas de publicação, APIs e sistemas móveis, possui cerca de 200 funcionários. Na área de design de produtos digitais, são cerca de 30 pessoas atuando.

Hagman explica que o aplicativo do jornal foi desenhado a partir da ideia de oferecer ao usuário o NYT completo dentro do telefone, algo que, segundo ele, foi também uma resposta recebida em pesquisas com leitores que demonstraram ter esse desejo. O que pode ser considerado justamente o desafio na hora de entregar o conteúdo no dispositivo móvel, na medida em que, por ser um artefato completamente diferente, ele não compõe receber o mesmo conteúdo, formatado da mesma maneira para o usuário. Essa questão fica mais clara ao aplicarmos nosso segundo instrumento de observação junto ao app do NYT, pois assim também podemos fazer algumas considerações com relação ao design de navegação e de interface do aplicativo.

Tabela 2 - Análise do Design de Navegação do app do NYT

\begin{tabular}{c|c|c|c}
\hline & Implementada & $\begin{array}{c}\text { Parcialmente } \\
\text { Implementada }\end{array}$ & Não Implementada \\
\hline $\mathbf{1}$ & & $\mathrm{X}$ & \\
\hline $\mathbf{2}$ & $\mathrm{X}$ & & \\
\hline $\mathbf{3}$ & $\mathrm{X}$ & & $\mathrm{X}$ \\
\hline $\mathbf{4}$ & & & $\mathrm{X}$ \\
\hline $\mathbf{5}$ & $\mathrm{X}$ & $\mathrm{X}$ & \\
\hline $\mathbf{6}$ & & & $\mathrm{X}$ \\
\hline $\mathbf{7}$ & $\mathrm{X}$ & & \\
\hline $\mathbf{8}$ & $\mathrm{X}$ & & \\
\hline $\mathbf{9}$ & $\mathrm{X}$ & $\mathrm{X}$ & \\
\hline 10 & & & $\mathrm{X}$ \\
\hline 11 & $\mathrm{X}$ & & \\
\hline 12 & $\mathrm{X}$ & & \\
\hline 13 & & & \\
\hline 14 & & & \\
\hline 15 & & & \\
\hline
\end{tabular}

Fonte: a autora 
Gráfico 2 - Representação da Análise do Design de Navegação no app do NYT

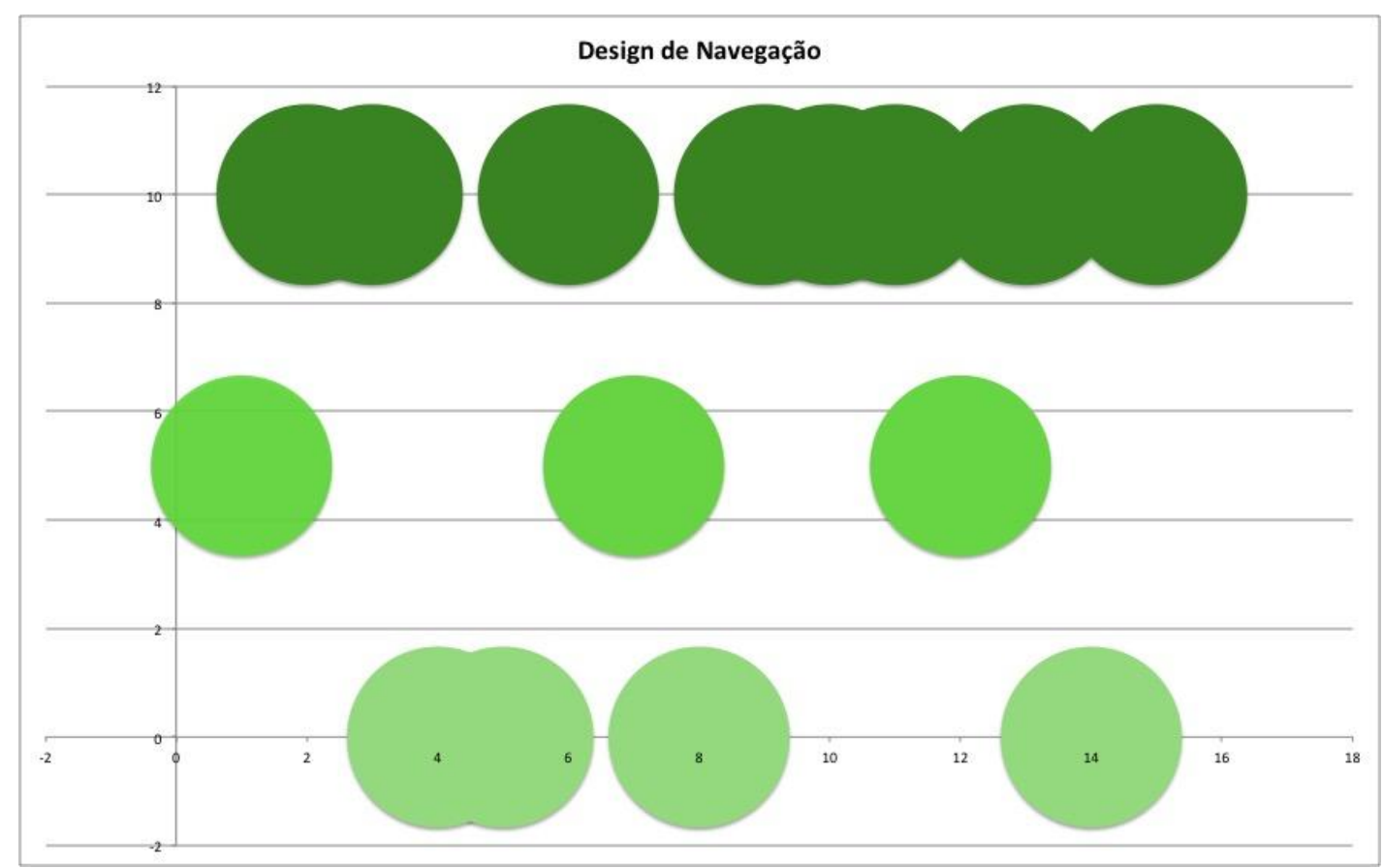

Fonte: a autora

Tabela 3 - Avaliação do Design de Interface do app do NYT

\begin{tabular}{|c|c|c|c|}
\hline & Implementada & $\begin{array}{l}\text { Parcialmente } \\
\text { Implementada }\end{array}$ & Não Implementada \\
\hline 16 & $\mathbf{X}$ & & \\
\hline 17 & $\mathbf{X}$ & & \\
\hline 18 & & $\mathbf{X}$ & \\
\hline 19 & $\mathbf{X}$ & & \\
\hline 20 & & & $\mathbf{X}$ \\
\hline 21 & & $\mathbf{X}$ & \\
\hline 22 & $\mathbf{X}$ & & \\
\hline 23 & & $\mathbf{X}$ & \\
\hline 24 & & & $\mathbf{X}$ \\
\hline 25 & & $\mathbf{X}$ & \\
\hline 26 & $\mathbf{X}$ & & \\
\hline 27 & $\mathbf{X}$ & & \\
\hline 28 & & $\mathbf{X}$ & \\
\hline 29 & $\mathbf{X}$ & & \\
\hline 30 & $\mathbf{X}$ & & \\
\hline
\end{tabular}

Fonte: a autora 
Gráfico 3 - Representação da Análise do Design de Interface do app do NYT

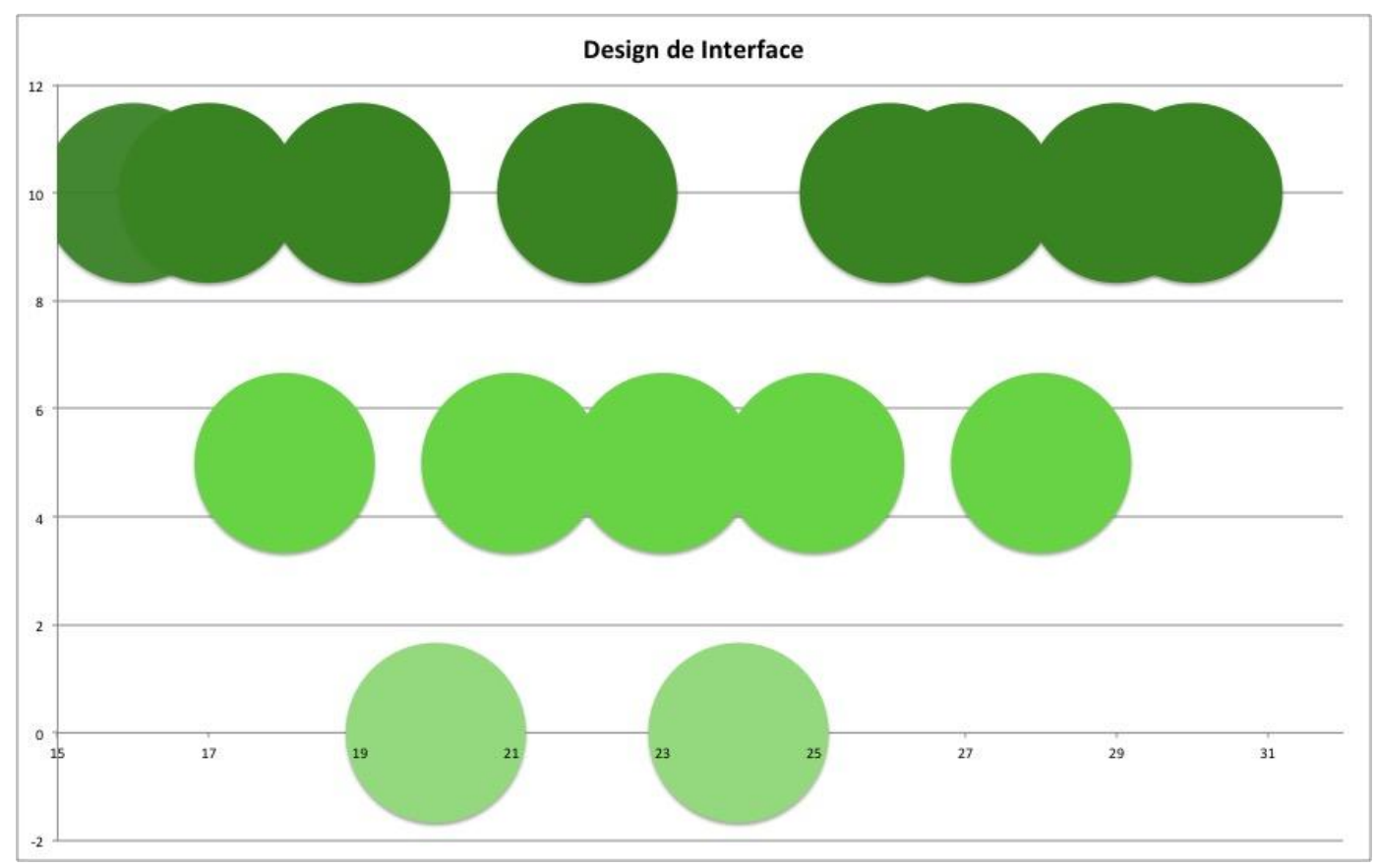

Fonte: a autora

Já quando analisamos as tabelas e os gráficos acima (tabelas e gráficos 2 e 3), relacionadas ao design de navegação e ao design de interface do aplicativo do NYT para smartphones, podemos perceber que nesses quesitos a empresa encontra-se muito mais adequada às características do jornalismo contemporâneo e também da formatação de narrativas para os dispositivos digitais mais atuais. De 30 categorias, 16 (53\%) estão implementadas e $8(27 \%)$ aparecem como parcialmente implementadas, ou seja, mais da metade já apresenta um desenvolvimento adequado aos dispositivos digitais e, do restante, a maioria já demonstra estar num caminho de desenvolvimento.

Alguns pontos, no entanto, valem ser destacados. O sistema oferece mensagens de erro claras, no entanto, não dá ao usuário nenhuma proposta de solução para o problema que foi encontrado, é preciso que o próprio leitor defina qual alternativa será seguida para resolver a questão. Na busca, o sistema também não é capaz de corrigir algum erro de digitação ou escrita do usuário, gerando resultados vazios sempre que ocorre algum problema. Também, em se tratando de resposta ao usuário, o aplicativo não possui um feedback sensorial, o que pode tornar a navegação um pouco mais difícil para alguns usuários, pois eles não são informados do caminho que está sendo percorrido no uso do app. 
$\mathrm{Na}$ área de interface, dois pontos valem ser destacados. O primeiro é que o menu do aplicativo (figura 10) oferece 42 opções de navegação, além de necessitar de rolagem para que se vejam todas essas opções. Esse excesso certamente deriva da proposta citada por Hagman de oferecer o produto por completo dentro do dispositivo móvel digital. Apesar de ter o objetivo de não deixar o usuário do smartphone sem receber a experiência completa do jornal, a empresa não encontrou ainda uma forma de fazê-lo que seja adaptada aos modos específicos e diferentes de consumo de conteúdo nesse tipo de artefato.

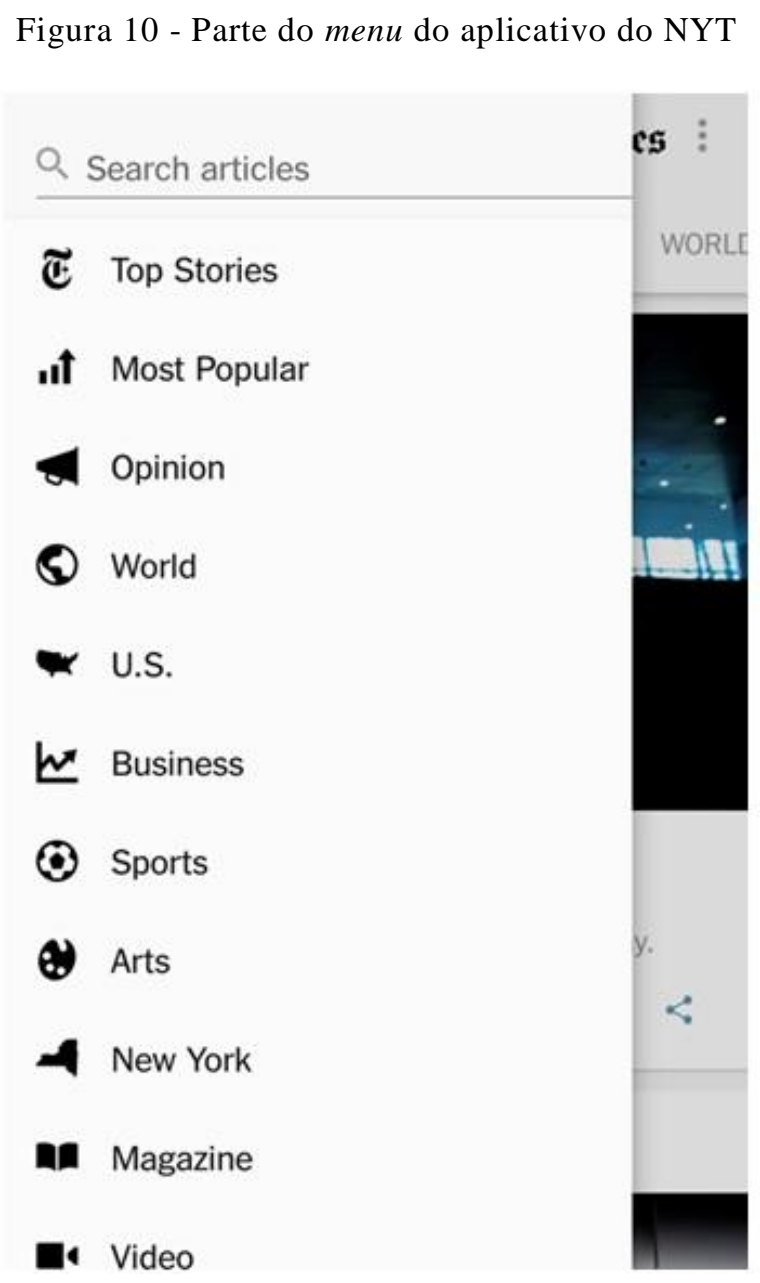

Além do excesso de opções disponíveis no menu, os textos das reportagens costumam ser bastante longos e sua formatação não difere da que é apresentada no desktop. O usuário precisa rolar muitas vezes a tela para chegar ao final da notícia e, embora uma vez no final ele receba links e opções para seguir a navegação, a leitura de um texto tão grande numa tela pequena pode ser cansativa e fazer com que o leitor 
disperse para outra interação possível e acabe não tendo, de forma alguma, a experiência completa do jornal no celular.

Outra dificuldade dentro do modo de formatação é a presença de links dentro do texto destacados somente pela troca de cor e uso do sublinhado como pode ser visto na imagem com a visão interna de um artigo aberto no aplicativo do NYT, mostrada anteriormente na figura 9. Esse tipo de construção da hipertextualidade não é adequado, segundo Shitkova et al. (2015), porque na experiência de leitura do usuário no smartphone não existem abas para dividir o conteúdo, fazendo com que o movimento de ir e voltar num texto seja prejudicado, demandando uma inovação no desenho dessa interação por parte da equipe responsável.

Alguns pontos positivos, no entanto, valem ser destacados. Além de oferecer a possibilidade de personalizar as notificações por push, o aplicativo do NYT, por padrão, notifica o usuário do recebimento do alerta somente por vibração, sem u so de som, o que se torna bastante importante, na medida em que o jornal envia conteúdo a qualquer momento do dia, podendo acordar o leitor ou interrompê-lo durante uma reunião, por exemplo. Outro aspecto positivo é o uso da publicidade dentro do aplicativo. Em nenhum momento ela é invasiva, aparece poucas vezes ao longo do texto e na ampla maioria dos casos se refere ao próprio jornal, ou seja, é um anúncio de alguma seção, caderno especial, suplemento ou serviço oferecido pelo veículo. Além disso, as imagens das reportagens podem ser aumentadas na tela conforme o desejo do leitor e os vídeos possuem a opção de desativar a alta definição, o que pode ser uma boa saída no caso de quem precisa economizar o pacote de dados do telefone.

No tocante aos pontos 12 e 13 do Quadro 1, mostrado anteriormente, o NYT é um bom exemplo de redação mobile first e de profissionais com multicompetências atuando na empresa. Conforme já comentamos, o NYT implantou em sua redação uma lógica em que a maioria dos profissionais atua para produzir conteúdo para plataformas digitais e, dentro dessas, priorizam os dispositivos móveis. A área do jornal impresso, embora ainda muito relevante e importante para a marca, já é gerenciada por apenas um grupo de editores e não por toda redação como ocorria tradicionalmente nos veículos jornalísticos. Outro ponto que reforça essa estratégia é o relatório ${ }^{82}$ recém-lançado pela companhia onde os autores afirmam: “Apesar de todo progresso que tivemos, nós ainda não construímos um negócio digital grande o suficiente por si só para suportar uma

\footnotetext{
82 https://www.nytimes.com/projects/2020-report/
} 
redação que consiga satisfazer nossas ambições". Para alcançar esses objetivos, o NYT planeja aumentar seu faturamento digital em 800 milhões de dólares até o ano de 2020 e o foco dessa proposta é ampliar as assinaturas digitais. A empresa pretende contratar ainda este ano, 2017, de acordo com o documento, um editor de "recursos digitais" que possa ser responsável por aumentar as "apostas digitais” do jornal. O que também demonstra o seu interesse por profissionais com multicompetências, capazes de compreender as características específicas da produção para plataformas digitais e, a partir disso, dialogar e promover ideias com programadores, designers e profissionais de tecnologia. Nesse mesmo relatório, os diretores admitem que a maioria do conteúdo produzido pelo NYT ainda se baseia em texto (o que exemplifica nossa fala sobre os grandes volumes de texto no aplicativo) e, por isso, eles pretendem, também neste ano, investir em treinamentos para os profissionais, sobre ferramentas de visualização da informação. Dentro dessa meta, o jornal também irá trocar o seu sistema publicador por um que dê mais atenção às questões gráficas e visuais da informação, além de contratar mais profissionais nessa área.

\subsection{The Guardian}

O The Guardian é um jornal britânico nascido em 1821, sendo que até 1959 denominava-se Manchester Guardian. A empresa tem o diferencial de ser controlada por um fundo chamado The Scott Trust Limited, fundado em 1936. O fundo se tornou limitado em 2008, o que faz com que seus controladores não obtenham lucro a partir da operação da empresa e esse, quando existir, seja sempre reinvestido no jornal. O Guardian é o único jornal britânico a ter um profissional no cargo de ombudsman. Ao contrário do NYT, a publicação não possui paywall, ao final de cada conteúdo exibido em suas plataformas, os usuários são convidados a conhecer o programa de associação ao jornal, que é semelhante a uma assinatura e tem diferentes modelos de participação e pagamento.

O Guardian lançou seu primeiro aplicativo para iPhone em 2009. Em 2011, a empresa lançou os aplicativos para Windows Phone e Android, e foi somente nesse mesmo ano que a empresa descontinuou o serviço de envio de SMS com notícias para os usuários cadastrados, orientando-os a utilizar os aplicativos, o site mobile ou então seguir as contas do Twitter da empresa. Ainda em 2011, o grupo lançou um comunicado 
onde afirmava que o Guardian e o Observer, jornal controlado pelo mesmo fundo, adotariam uma estratégia "digital-first", onde as plataformas digitais são priorizadas dentro da operação da empresa. O comunicado veio após um acúmulo de perdas de 33 milhões de libras no ano anterior. Logo após o anúncio, o jornal lançou sua versão para iPad. A partir daí, o jornal investiu fortemente, ao longo dos anos, em atualizações dos aplicativos e na criação no site móvel. Em 2014, a empresa lançou também um serviço para o Google Glass. Atualmente, o Guardian conta com um app para Apple Watch. Em 2016, o grupo que controla o jornal anunciou que as perdas anuais em faturamento seguem crescendo (69 milhões de libras naquele ano), no entanto, a empresa aposta no crescimento da base de associados digitais que já passa de 50 mil.

No final de 2015, o jornal anunciou a criação do "Guardian Mobile Innovation Lab". O local é uma espécie de laboratório onde o jornal testa diversos tipos de ação, formatos e propostas para o jornalismo nos dispositivos móveis digitais. A editora do laboratório é a jornalista Sasha Koren que divide a coordenação com a gerente de produto sênior Sarah Schmalbach. Em maio de 2016, tivemos a oportunidade de entrevistar as duas e a editora adjunta Madeline Welsh na sede do laboratório em Nova York, onde também funciona a redação norte-americana do jornal. As atividades do laboratório são financiadas pela John S. and James L. Knight Foundation, fundação responsável pelo apoio a diversos projetos jornalísticos nos Estados Unidos.

O laboratório de inovação do Guardian foi estabelecido em Nova York por dois motivos, segundo Sarah Schmalbach: primeiro porque é financiado pela Knight Foundation, que, na ampla maioria dos casos, auxilia iniciativas norte-americanas ou, pelo menos, localizadas nos Estados Unidos; segundo, porque o processo de testes e investigação proporcionado pelo laboratório funcionaria melhor dentro de uma redação com menos pessoas - caso de Nova York -, onde as ideias pudessem ser realizadas sem a necessidade de trabalhar com toda a audiência global do jornal e também pudessem ser testadas em sistemas externos ao aplicativo principal. "As empresas de jornalismo não estão dando o salto para o mobile tão rápido quanto deveriam. Isto é algo sabido, mas acredito que valha a pena ser dito para dar o contexto do por que o Guardian acreditou que seria importante estabelecer o laboratório. A mudança de paradigma do impresso para o digital levou muito tempo e ainda está ocorrendo, então isso aqui é uma declaração de que o salto para o mobile precisa ser muito mais rápido”, afirma Sasha Koren. 
A análise do aplicativo do jornal The Guardian foi feita sob as mesmas condições técnicas já citadas e também durante o mês de fevereiro de 2017. Iniciamos nossa observação pelas características avaliadas a partir de nosso primeiro instrumento de pesquisa.

Figura 11 - Página inicial do app do Guardian

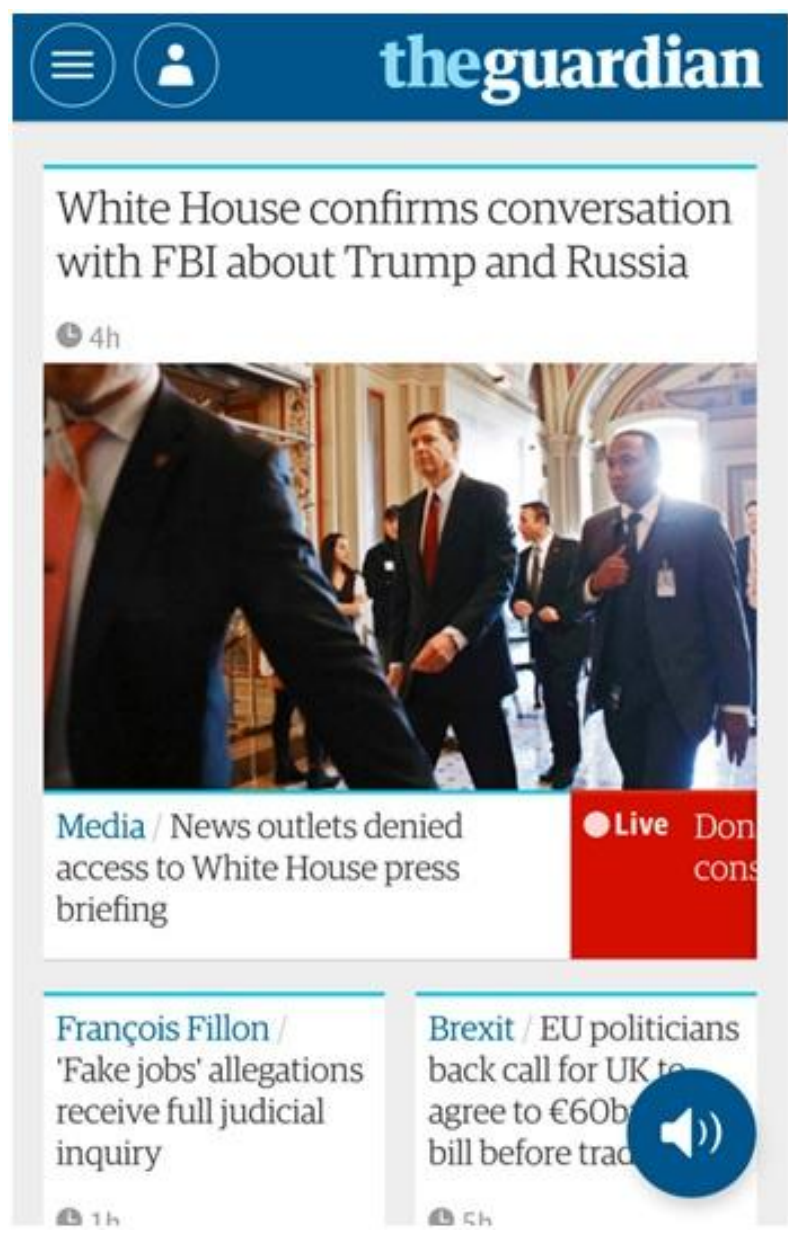

Assim como o primeiro aplicativo observado em nossa análise, o app do Guardian também não utiliza dados de geolocalização para enriquecer a experiência do usuário com o produto. Um mínimo elemento é utilizado para perceber o local onde o usuário está e adaptar a hora exibida no aplicativo para o fuso horário local. Essa funcionalidade, no entanto, não faz nada além de identificar a hora que é exibida no próprio aparelho e reproduzi-la, não oferecendo diferencial para o leitor.

O aplicativo não oferece conteúdos geolocalizados, ou qualquer outro tipo de personalização de consumo com relação à localização do usuário, com exceção da 
possibilidade de escolher qual edição se quer ler, norte-americana, inglesa, australiana ou internacional. Não é possível selecionar notícias a partir do um geo tagueamento (no caso de as notícias receberem etiquetas com a sua localização, essas não são manipuláveis pelo usuário), assim como o aplicativo também não captura a localização para o envio de informações personalizadas e mais próximas. De acordo com as coordenadoras do Mobile Lab, Sarah Schmalbach and Sasha Koren, essa função não é implementada por uma série de fatores que ainda não estão claros para os jornalistas. Entre eles, há dúvidas sobre até que ponto o jornal deve ir ao solicitar a localização do usuário, sem que isso se torne invasivo ou antiético. Além disso, não há consenso sobre um bom formato para enviar notificações geolocalizadas com dúvidas sobre que conteúdo enviar, quando enviar, o que o usuário quer receber e até que ponto ele não será incomodado por esse "assédio".

A questão da geolocalização, para Sarah, entra na área de entrega de conteúdo contextual. Segundo ela, a tecnologia presente na empresa e no aplicativo, hoje, permite que se saiba o país ou até a cidade onde o usuário está, no entanto, pontos mais específicos e graus menores de localização ainda não são possíveis. O laboratório preparava, na época, a realização de um workshop com leitores para entender que tipos de permissões seriam viáveis e permitidas no dispositivo móvel, como o acesso à geolocalização, acelerômetro e giroscópio ${ }^{83}$, por exemplo. "A ideia é entender que tipo de experiência o usuário quer, para que valha a pena dar determinadas permissões a uma empresa jornalística. Estamos construindo uma pesquisa para entender como vamos querer e poder usar geolocalização em nosso produto", afirma Sarah. "Nós todos provavelmente estamos usando nossos dispositivos de forma que disponibilizam informações pessoais das quais não estamos conscientes e que se estivéssemos conscientes ficaríamos apavorados. Então eu penso que se as organizações jornalísticas quiserem usar essas informações elas precisam fazer isso de uma forma ética e transparente", complementa Sasha.

Também como o NYT, o aplicativo do Guardian não tem integração com outros dispositivos, exceto pela possibilidade e enviar conteúdo para outros aparelhos por bluetooth. Nesse sentido, com relação à redistribuição de conteúdo, o aplicativo possui conexão com redes sociais, e-mail e aplicativos de mensagem, permitindo que o usuário

\footnotetext{
${ }^{83} \mathrm{O}$ giroscópio é um dispositivo usado para detectar mudanças de direção de um objeto, no celular ele é capaz de indicar para onde o usuário está se movendo. O acelerômetro é um instrumento que mede a força aplicada sobre ele, no celular ele identifica a movimentação e o direcionamento da tela.
} 
compartilhe de diversas formas o conteúdo que está lendo com outras pessoas da sua rede, de forma eficaz e efetiva.

No que se refere à leitura em camadas, o Guardian apresenta algumas opções interessantes que fazem com que essa categoria se mostre como em implantação. $\mathrm{O}$ aplicativo oferece a opção de receber alertas de uma notícia em específico. Por exemplo, se um evento de relevância ocorreu - como um atentado terrorista - e seus desdobramentos ainda estão sendo apurados, o usuário pode optar por seguir aquela história e então receber alertas toda vez que um novo texto sobre o tema for publicado. Quando algo está sendo reportado em tempo real, o aplicativo exibe um chapéu com a palavra Live (ao vivo) na tela inicial e marca esse conteúdo em vermelho. Uma vez dentro do texto também é possível optar por receber informações específicas daquele conteúdo sempre que algo novo for publicado. Ou seja, se algum assunto interessa muito ao leitor e ele já consumiu o conteúdo que estava disponível, ele pode optar por se aprofundar no tema a todo o momento que receber um alerta do aplicativo.

Figura 12 - Cobertura em tempo real no app do Guardian

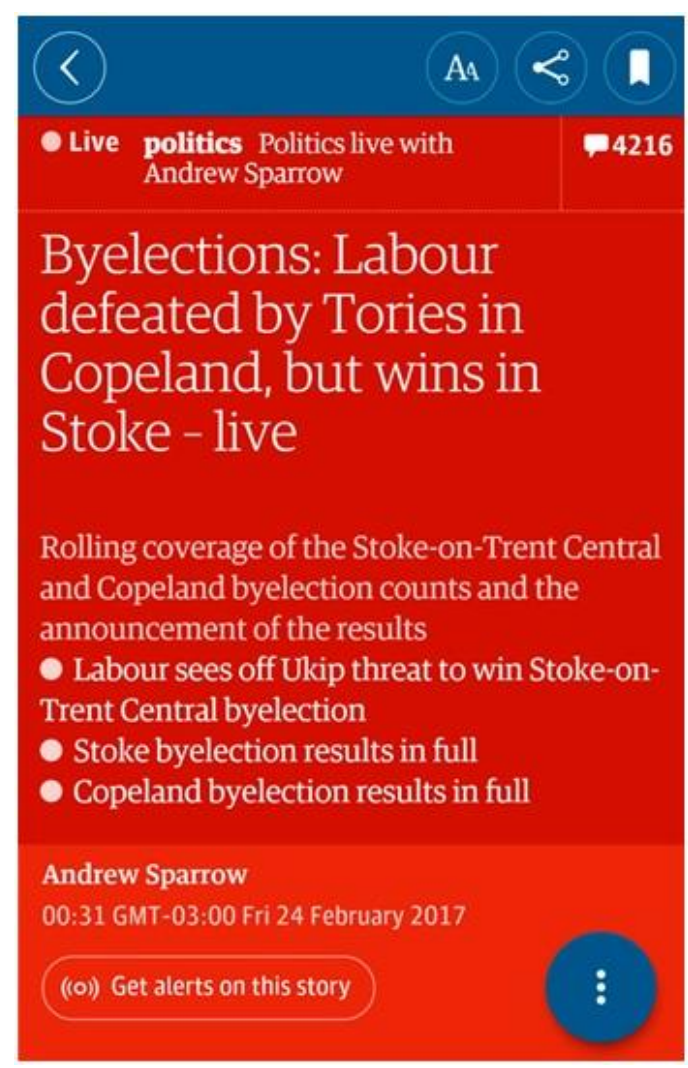


Outro recurso que traz a ideia de leitura em camadas é a grande quantidade de notícias relacionadas que o aplicativo oferece ao final do texto. Quando se chega ao final de um artigo, uma série de conteúdos relativos ao mesmo tema é exibida como opções de leitura, o que permite, de certa forma, que o usuário se aprofunde de acordo com a sua vontade (figura 13). O jornal faz ainda um bom uso das tags (palavras-chave) exibidas também no final dos artigos. Tocando em alguma delas, o usuário é remetido para conteúdos ligados aos tópicos ali exibidos. Essas funcionalidades, embora não sejam inéditas no jornalismo para plataformas digitais, se mostram mais bem trabalhadas no aplicativo do Guardian. Outros apps, normalmente, exibem ao final dos textos links de outros conteúdos publicados na mesma editoria, ou outros conteúdos organizados de forma cronológica, enquanto o Guardian exibe artigos diretamente ligados ao assunto que está sendo lido.

Figura 13 - Artigos relacionados e tags ao final do texto no app do Guardian

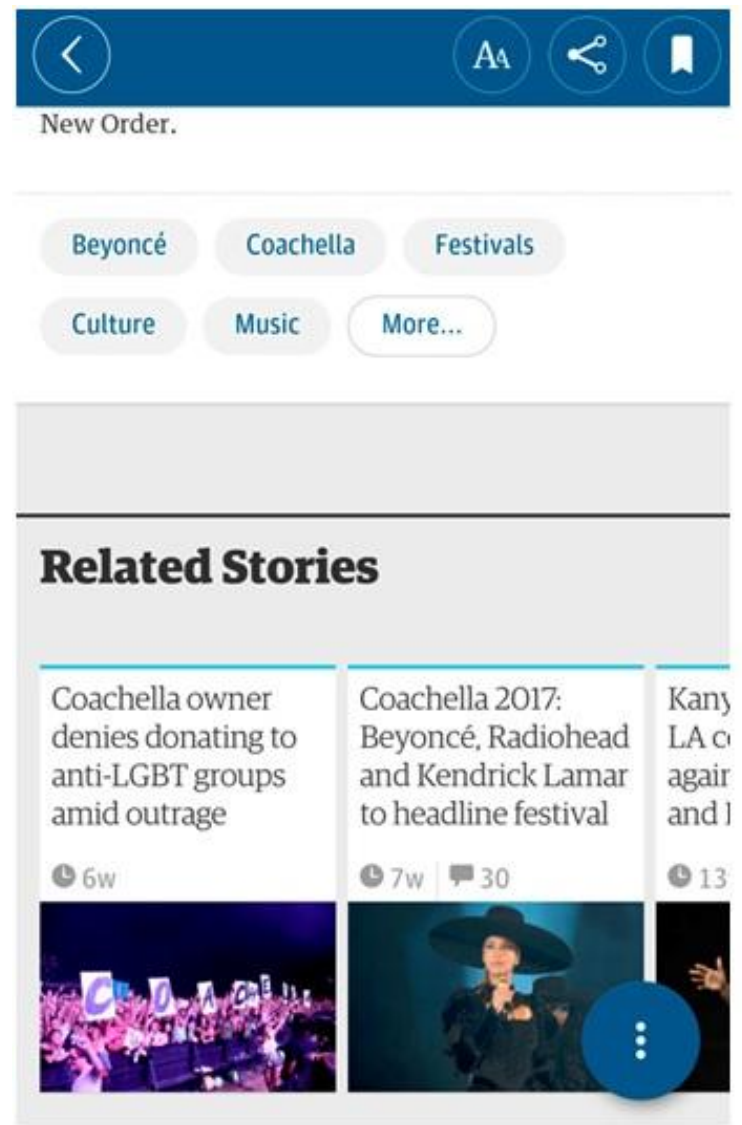

Outro diferencial está no aplicativo permitir que o usuário siga os repórteres ou colunistas de sua preferência, enviando uma notificação toda vez que o profissional 
publica um novo conteúdo (figura 14). A funcionalidade é interessante, por exemplo, no caso de correspondentes estrangeiros, na medida em que o leitor pode decidir seguir o profissional responsável pela cobertura de uma área do seu interesse. Ou também no caso de um colunista da preferência do leitor, ou um repórter especializado numa editoria específica, cria-se uma relação de proximidade entre o leitor e o jornal, além de personalizar a notícia e sua produção.

Figura 14 - Recurso de seguir profissionais no app do Guardian

\begin{tabular}{|c|c|}
\hline \multicolumn{2}{|c|}{$\begin{array}{l}\text { The VX nerve agent that killed North Korea's Kim } \\
\text { Jong-nam is described as a weapon of mass destruction by } \\
\text { the UN. Photograph: OJO Images/Rex/Shutterstock }\end{array}$} \\
\hline \multicolumn{2}{|c|}{$\begin{array}{l}\text { Justin McCurry } \\
\text { 23:37 GMT-03:00 Thu } 23 \text { February } 2017\end{array}$} \\
\hline \multicolumn{2}{|c|}{$\begin{array}{l}\text { Malaysian police have revealed that the nerve agent VX } \\
\text { was used to kill Kim Jong-nam when he was attacked } \\
\text { at Kuala Lumpur's international airport. }\end{array}$} \\
\hline \multicolumn{2}{|c|}{$\begin{array}{l}\text { What is vX? } \\
\text { VX is the deadliest nerve agent ever created. Just a tiny } \\
\text { drop absorbed through the skin is enough to cause } \\
\text { "fatal disruption of the nervous system", according to } \\
\text { the Council on Foreign Relations. }\end{array}$} \\
\hline $\begin{array}{l}\text { More on this topic } \\
\text { Kim Jong-nam killed } \\
\text { by VX nerve agent, a } \\
\text { chemical weapon, say } \\
\text { Malaysian police }\end{array}$ & $\begin{array}{l}\text { It is } 100 \text { times more deadly } \\
\text { than the nerve gas sarin, } \\
\text { which was used by members } \\
\text { of a Japanese doom } \\
\text { in their deadly } 1995 \\
\text { the Tokyo subway. }\end{array}$ \\
\hline
\end{tabular}

O aplicativo também oferece bons recursos de personalização e fluxo de dados. O usuário pode personalizar a tela inicial, definindo quais editorias deseja ler ou ver preferencialmente, pois além de incluir ou excluir seções, também é possível organizálas na ordem preferida. O jornal ainda utiliza algoritmos para capturar informações sobre hábitos de leitura do usuário e, posteriormente, utilizar esses dados na sugestão de conteúdos (figura 15). Essa funcionalidade, no entanto, não é automática. O aplicativo solicita autorização ao usuário para enviar sugestões de conteúdos baseadas nos hábitos 
de leitura. $\mathrm{O}$ armazenamento dos dados de consumo do usuário fica evidente na seção onde ele pode consultar todos os últimos textos que foram lidos. Lá também está uma lista com os repórteres responsáveis pelos conteúdos consumidos e a oferta para seguilos. O app também permite salvar os textos preferidos para leitura posterior e fazer o download do conteúdo completo para visualização offline.

Figura 15 - Uso de algoritmos para recomendações no app do Guardian

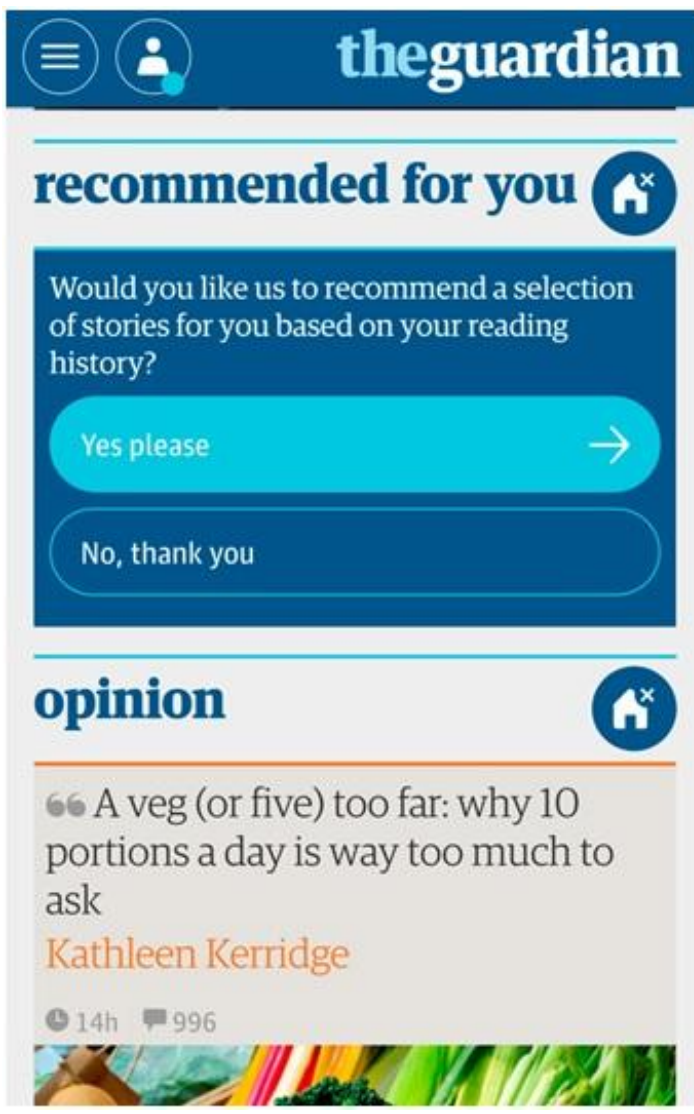

Apesar desses bons elementos, o Guardian ainda não oferece conteúdos contextualizados de acordo com a rotina e o momento de consumo do leitor. Além disso, sua integração com o sistema operacional do dispositivo também se resume às notificações enviadas. Essas, por sua vez, têm uma boa configuração onde o usuário pode escolher receber o alerta com som, só com vibração ou sem nenhum des ses. Entre as editorias, o usuário opta por notícias urgentes e esporte, sendo também possível receber avisos dos artigos salvos e não lidos, e dos comentários respondidos nas seções interativas dos textos. 
$\mathrm{Na}$ época da entrevista, as editoras tinham como metas desenvolver experimentos em duas áreas principais: notificações e coberturas ao vivo. Essas duas áreas fazem parte de um conjunto de cinco pontos estabelecidos por elas para serem pesquisados dentro das iniciativas propostas pelo laboratório, incluindo vídeo, entrega de conteúdo contextual e interação com o conteúdo. Com relação à cobertura ao vivo, o laboratório busca entender como entregar informação confiável de uma maneira direta e informal no máximo de plataformas móveis possíveis. Dentro de notificações, o objetivo é compreender como tirar proveito do imediatismo, da intimidade e da possibilidade de interrupção oferecidas pelos alertas no telefone. Sobre vídeo, as jornalistas querem entender como empresas jornalísticas fundadas sobre os preceitos do texto podem aprender a contar histórias com imagens e também gerar engajamento mais profundo a partir delas. Na área de entrega de conteúdo contextual, o laboratório admite que a maioria das empresas jornalísticas está muito atrás de serviços como, por exemplo, o Google Now e outros aplicativos comerciais que são capazes de oferecer informação relevante de acordo com as necessidades do usuário ao longo do dia, e também levando em consideração sua localização, atividade momentânea e período do dia. Com isso, a busca é por entender quais são os usos mais interessantes e úteis para a entrega contextual de notícias. Por último, em interação com o conteúdo, o grupo quer descobrir como aproveitar a potencialidade de redistribuição do celular e do comportamento dos usuários, a fim de criar trocas mais proveitosas e personalizadas para os leitores.

“Como entregamos informação, contexto e interatividade para uma audiência 'mobile first' ou 'mobile only ${ }^{, 84}$ ?', pergunta a gerente de produto Sarah Schmalbach. Entre os desafios para promover inovações e evoluções dentro dessas áreas, segundo Sasha Koren, estão a viabilidade da construção dos processos dentro da redação, tanto com relação à tecnologia existente, quanto à adaptação de hábitos e rotinas de trabalho. Uma das conclusões já obtidas a partir dos experimentos realizados dentro do laboratório foi a abertura do público para a conversa direta com colunistas e profissionais da redação. Segundo a editora, há um desejo por se conectar e fazer parte de uma comunidade com o veículo de notícias.

\footnotetext{
${ }^{84}$ Mobile first é uma expressão utilizada para indicar aquilo que é primeiro feito em ou para dispositivos móveis. Mobile only é a expressão que indica aquilo que é feito ou ocorre unicamente em dispositivos móveis.
} 
Tabela 4 - Avaliação 1 do app do Guardian

\begin{tabular}{c|c|c|c}
\hline & Implementada & $\begin{array}{c}\text { Parcialmente } \\
\text { Implementada }\end{array}$ & Não Implementada \\
\hline I & & & $\mathrm{X}$ \\
\hline II & & $\mathrm{X}$ & $\mathrm{X}$ \\
\hline III & $\mathrm{X}$ & & \\
\hline IV & $\mathrm{X}$ & & $\mathrm{X}$ \\
\hline V & & $\mathrm{X}$ & \\
\hline VI & & & \\
\hline VII & & &
\end{tabular}

Fonte: a autora

Gráfico 4 - Representação das categorias do JU no app do Guardian

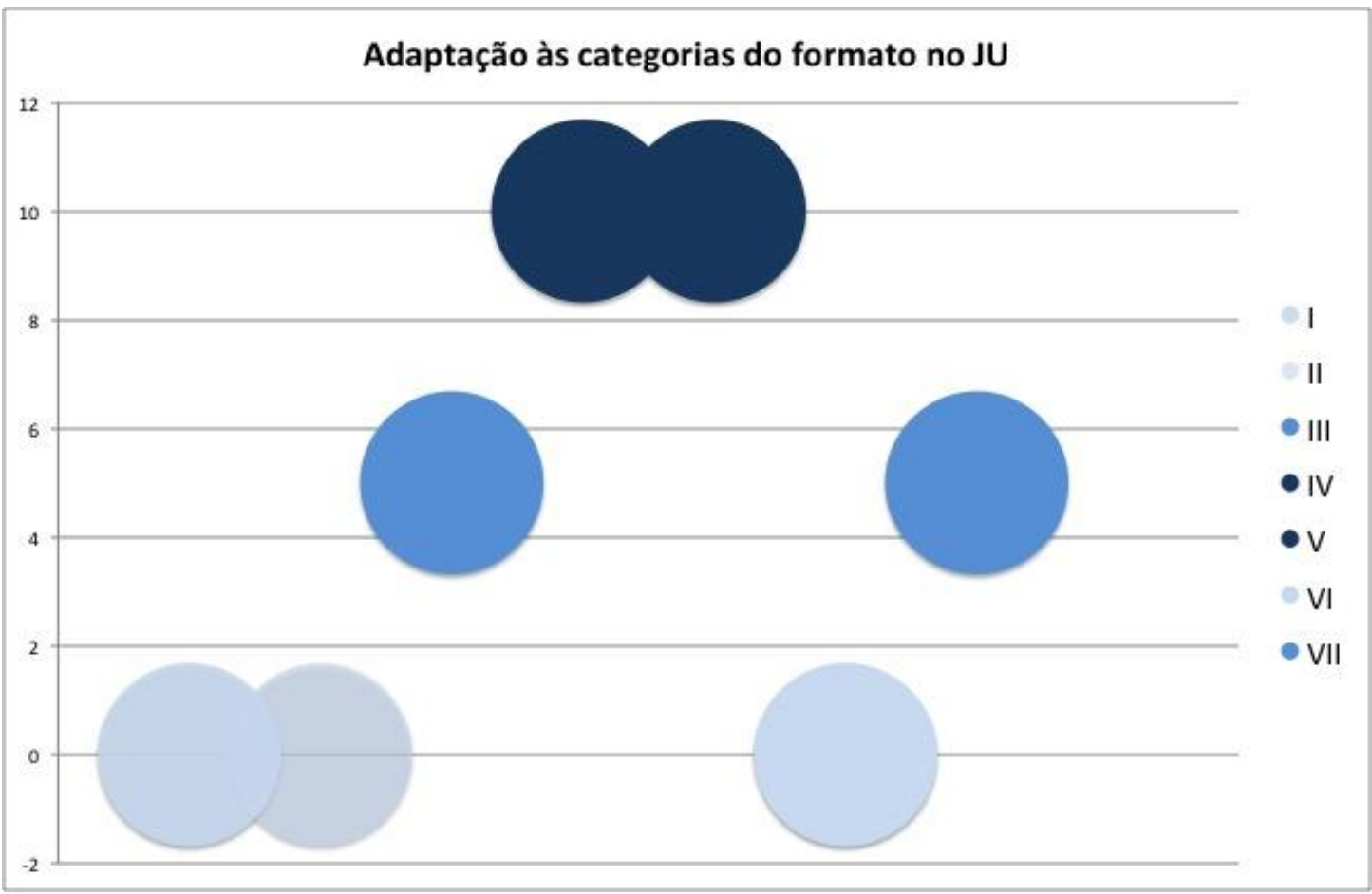

Fonte: a autora

Ao observar a tabela e o gráfico acima (4), percebemos que embora seja um aplicativo visualmente mais bonito e interessante do que os outros analisados, com relação às características do JU, o Guardian se assemelha ao NYT. Somente duas categorias estão implementadas (29\%), também duas (29\%) parcialmente implementadas e três $(42 \%)$ aparecem como não implementadas. O produto do jornal britânico explora alguns elementos a mais do que o concorrente norte-americano, no entanto, ainda 
esbarra nas limitações técnicas e editorias quando se trata de geolocalização e adaptação do conteúdo oferecido ao contexto de consumo dos usuários. Podemos dizer que ele também enfrenta um momento de transição, apesar de a empresa já ter um foco e estratégia digital há cerca de seis anos.

Sarah Schmalbach afirma que o aplicativo do Guardian, assim como todos os outros, tem pontos fortes e fracos, e ressalta que, muitas vezes, uma grande parte da operação é feita fora do olhar do público, mas se torna um grande desafio para a empresa responsável pelo produto. Uma dessas partes, segundo ela, está no trabalho de tornar o aplicativo estável e também em adaptá-lo à grande diversidade de dispositivos disponíveis no mercado. Esse trabalho, muitas vezes, acaba demandando muitos profissionais e tempo dessa equipe, que é "obrigada" a deixar o aplicativo em boas condições de uso em todos os aparelhos existentes no mercado. Diferentemente dos computadores desktop, que não possuíam grande variação entre modelos, sendo somente necessário adaptar os produtos aos sistemas operacionais que rodavam, os smartphones possuem grandes diferenças que vão além dos sistemas, fazendo com que os serviços precisem levar em conta software e hardware nesses casos.

Tabela 5 - Análise do Design de Navegação do app do Guardian

\begin{tabular}{c|c|c|c}
\hline & Implementada & $\begin{array}{c}\text { Parcialmente } \\
\text { Implementada }\end{array}$ & Não Implementada \\
\hline $\mathbf{1}$ & $\mathrm{X}$ & & \\
\hline $\mathbf{2}$ & $\mathrm{X}$ & & \\
\hline $\mathbf{3}$ & $\mathrm{X}$ & & $\mathrm{X}$ \\
\hline $\mathbf{4}$ & & & $\mathrm{X}$ \\
\hline $\mathbf{5}$ & $\mathrm{X}$ & & \\
\hline $\mathbf{6}$ & $\mathrm{X}$ & & $\mathrm{X}$ \\
\hline $\mathbf{7}$ & & & $\mathrm{X}$ \\
\hline $\mathbf{8}$ & $\mathrm{X}$ & & \\
\hline $\mathbf{9}$ & $\mathrm{X}$ & $\mathrm{X}$ & \\
\hline $\mathbf{1 0}$ & & & $\mathrm{X}$ \\
\hline $\mathbf{1 1}$ & $\mathrm{X}$ & & \\
\hline 12 & $\mathrm{X}$ & & \\
\hline 13 & & & \\
\hline 14 & & & \\
\hline 15 & & & \\
\hline
\end{tabular}

Fonte: a autora 
Gráfico 5 - Representação da Análise do Design de Navegação no app do Guardian

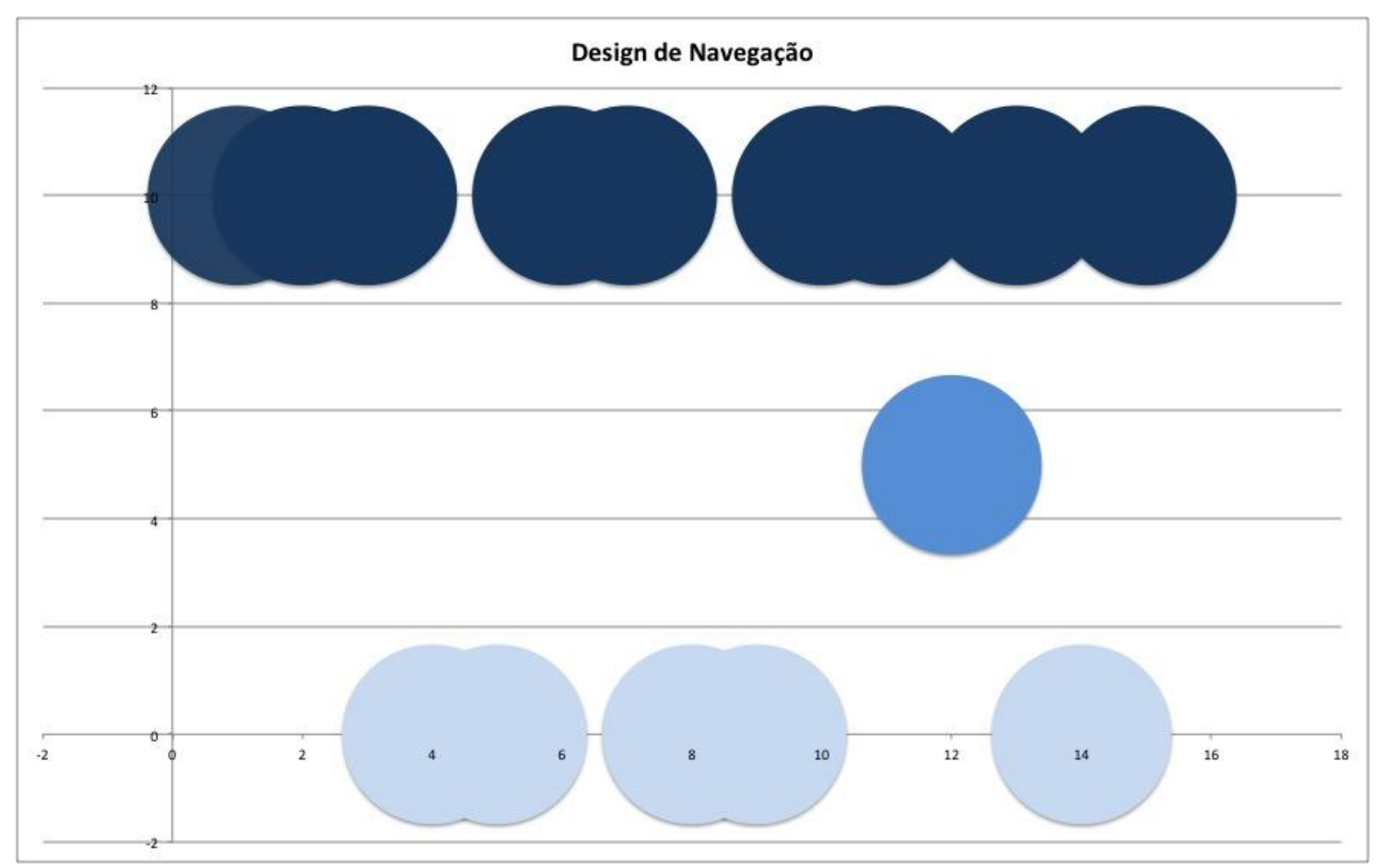

Fonte: a autora

Tabela 6 - Avaliação do Design de Interface do app do Guardian

\begin{tabular}{c|c|c|c}
\hline & Implementada & $\begin{array}{c}\text { Parcialmente } \\
\text { Implementada }\end{array}$ & Não Implementada \\
\hline $\mathbf{1 6}$ & $\mathrm{X}$ & & \\
\hline $\mathbf{1 7}$ & $\mathrm{X}$ & & \\
\hline $\mathbf{1 8}$ & $\mathrm{X}$ & & \\
\hline $\mathbf{1 9}$ & $\mathrm{X}$ & $\mathrm{X}$ & \\
\hline $\mathbf{2 0}$ & & $\mathrm{X}$ & \\
\hline $\mathbf{2 1}$ & $\mathrm{X}$ & $\mathrm{X}$ & \\
\hline $\mathbf{2 2}$ & $\mathrm{X}$ & & \\
\hline $\mathbf{2 3}$ & & & \\
\hline $\mathbf{2 4}$ & & $\mathrm{X}$ & \\
\hline $\mathbf{2 5}$ & $\mathrm{X}$ & $\mathrm{X}$ & \\
\hline $\mathbf{2 6}$ & $\mathrm{X}$ & & \\
\hline $\mathbf{2 7}$ & $\mathrm{X}$ & & \\
\hline $\mathbf{2 8}$ & & & \\
\hline 29 & & & \\
\hline 30 & & & \\
\hline
\end{tabular}

Fonte: a autora 
Gráfico 6 - Representação da Análise do Design de Interface do app do Guardian

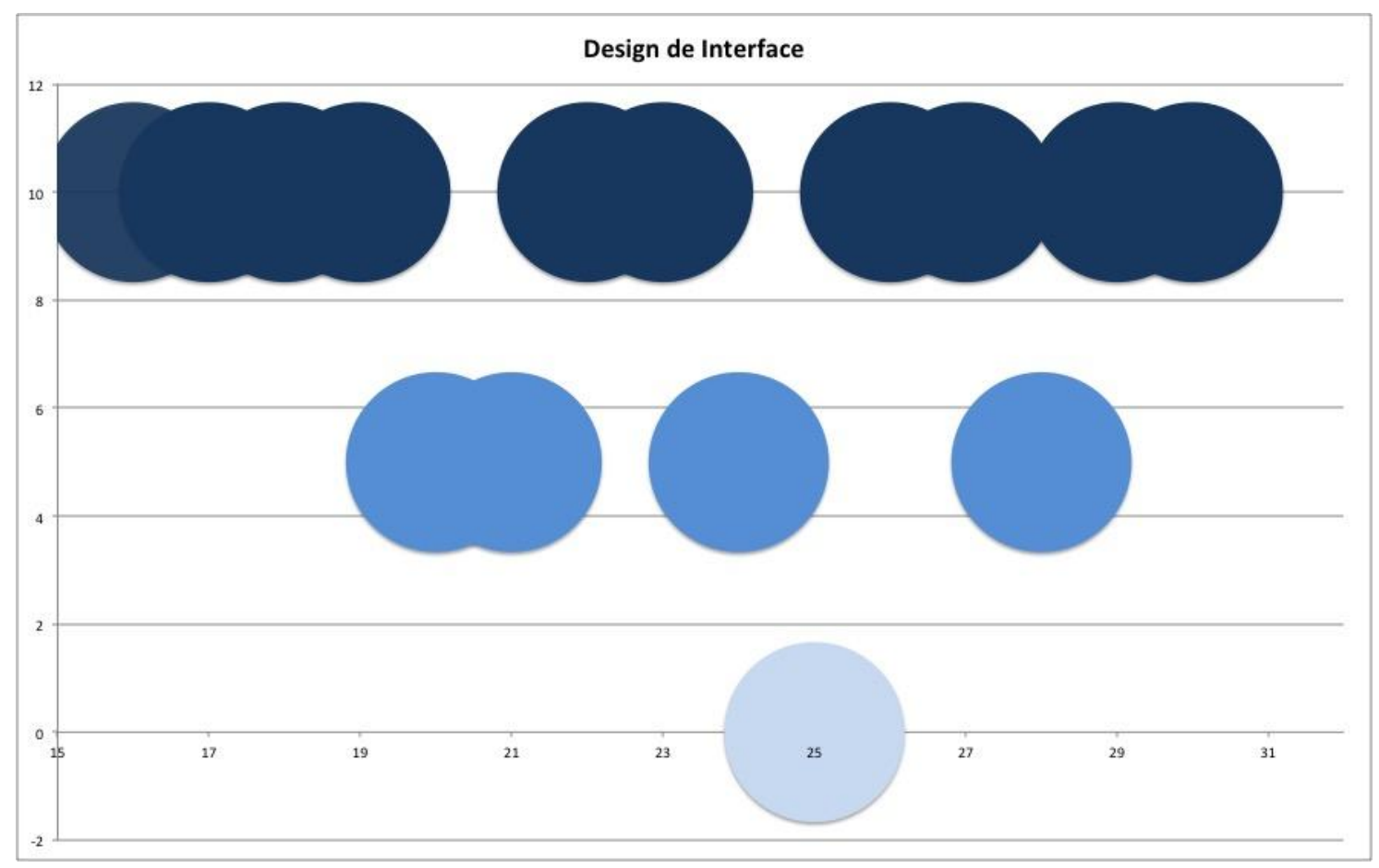

Fonte: a autora

Com relação aos designs de navegação e interface, o aplicativo do Guardian está em patamar semelhante ao do NYT, com 19 categorias implementadas (63\%) e 5 parcialmente implementadas (17\%). Nesse caso, uma parte significativa das características já estão implementadas, valendo destacar algumas e suas peculiaridades. O menu de navegação, embora peque no fato de não ser acessível em todas as telas do aplicativo, demanda pouca rolagem, totalizando somente 23 itens. Além disso, o aplicativo tem uma interface clara, com conteúdo centralizado e bem destacado, bom uso de cores para destaques e também com ícones bastante visíveis e identificáveis. As fotos podem ser ampliadas de acordo com o interesse do usuário e em galerias de imagens a navegação é horizontal, permitindo que o leitor deslize entre as fotos. O aplicativo ainda peca, assim como o NYT, na inserção de links no texto destacados somente pela mudança de cor da palavra e seu sublinhado, demonstrando que, apesar dos avanços, ainda não se encontrou uma maneira de adaptar a hipertextualidade dentro do texto ao formato de leitura próprio dos dispositivos móveis digitais, onde é difícil tocar corretamente links tão pequenos e que abrem outra área de leitura num ambiente sem abas. 
As interações com o conteúdo seguem o padrão e consistência da maioria dos serviços de conteúdos jornalísticos, com leitura sendo realizada na vertical e rolagem entre temas e textos na horizontal. No quesito acessibilidade, além de permitir que os usuários modifiquem o tamanho da letra e o brilho da tela, o aplicativo oferece um serviço interessante chamado "Read it to me" ("leia isto para mim") acionado a partir de um ícone de áudio na tela inicial. Ao clicar na opção, o aplicativo inicia a leitura dos textos completos das matérias principais destacadas na tela inicial. A opção também pode ser acionada dentro de qualquer um dos outros artigos disponíveis no app.

O aplicativo tem um carregamento rápido (menos de 5 segundos para carregar a tela inicial) e facilita o uso do leitor que quer economizar tempo ou dados do plano de internet ao oferecer uma opção de layout condensado da tela inicial. Nessa opção, as fotos aparecem menores, assim como as manchetes de cada um dos textos destacados. Outro ponto que favorece a rapidez é um navegador interno ao aplicativo que, uma vez ativado, permite que o usuário carregue rapidamente dentro da própria interface um link de algum site externo relacionado ao tema que está sendo lido.

Um dos aspectos negativos com relação à interface do app do Guardian diz respeito à publicidade. O aplicativo exibe publicidade de produtos externos e não relacionados ao jornal, normalmente em forma de imagem no meio dos textos (figura 16). O tamanho da imagem e sua discrepância com relação ao design do aplicativo tornam a leitura menos interessante e atrapalham a interação com o conteúdo. Como diferencial, o jornal oferece aos seus assinantes uma versão completamente sem publicidade do seu aplicativo. Além disso, os "associados" do Guardian também têm acesso a conteúdos premium exclusivos. 
Figura 16 - Publicidade no app do Guardian

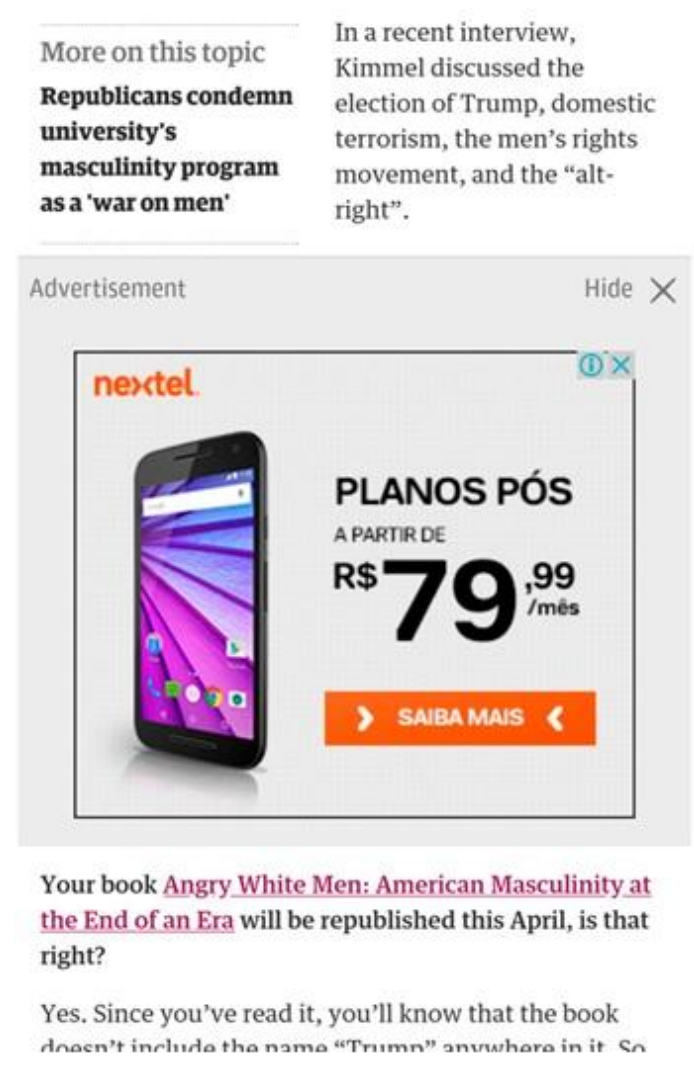

Com relação aos pontos 12 e 13 do Quadro 1, podemos considerar também que o Guardian tem uma redação com foco nos dispositivos móveis e, essa mesma redação, é composta por profissionais de múltiplas competências e áreas de especialização. Desde 2011, ao anunciar sua estratégia "digital-first", o jornal já demonstrava uma inclinação em direção à valorização dos produtos que podem garantir a sobrevivência da empresa ao longo das próximas décadas. Além disso, a criação de um laboratório focado especificamente nesse tema e todos os experimentos ${ }^{85}$ que são desenvolvidos dentro desse local, demonstram um objetivo em investir na busca da melhor formatação de seus produtos tanto para esses dispositivos quanto para os consumidores que estão plenamente conectados ao uso desses artefatos em seu dia a dia.

Segundo a editora Sasha Koren, a inovação é uma parte da cultura interna do Guardian. Segundo ela, a redação se mostra aberta e disposta a realizar testes e experimentos junto ao laboratório para pensar em soluções que possam trazer melhorias

\footnotetext{
${ }^{85}$ Todos os experimentos realizados pelo Guardian Mobile Innovation Lab são abertos e publicados para uso geral, esta é uma das condições estabelecidas para o financiamento pela Knight Foundation. As descrições dos testes e suas análises podem ser conferidas no site https://medium.com/the-guardianmobile-innovation-lab.
} 
aos produtos móveis da empresa. Sasha trabalhou de 1998 a 2015 no NYT e diz que o Guardian demonstra ter uma cultura interna menos tradicional que a do concorrente e uma abertura maior para mudanças nos métodos da empresa. Sarah acredita que es sa cultura é, na verdade, uma "cultura de sobrevivência", que ocorre quando as empresas percebem que não vão sobreviver às próximas décadas se não se adaptarem aos novos formatos.

Vale mencionar, ainda, que o Guardian também investe em narrativas imersivas com uso de realidade virtual. No primeiro trimestre de 2016, o jornal lançou sua primeira experiência para realidade virtual intitulada 6x9, mostrando como é uma cela de prisão solitária nos Estados Unidos e contando histórias de danos psicológicos causados pelo isolamento. A experiência foi bastante comentada, pois gerava desconforto ao deixar o usuário com uma sensação próxima ao de prisioneiro que fica confinado naquele tipo de espaço, demonstrando o impacto que esse tipo de produção pode ter ao proporcionar ao leitor uma sensação que provavelmente não seria possível de se ter apenas lendo um texto que descrevesse o formato das celas.

\subsection{El País}

O El País é um jornal espanhol fundado em 1976, quando a Espanha começava sua transição para o regime democrático. A sede principal do jornal fica localizada em Madrid, mas ele tem redações também em Barcelona, Bilbao, Sevilha, Valência, Santiago de Compostela, México e Brasil. No aplicativo, ele oferece as edições Espanha, América, Catalunha e Brasil. Na web, o site do jornal oferece três edições: Espanha, América e Brasil, além de uma seção com conteúdos em inglês. O El País colocou seu site no ar em 1996 ainda com foco somente na Espanha. Em 2000, seu domínio passou a ser .com, em vez de .es, para enfatizar o caráter internacional que se buscava para a publicação. O site do El País é o jornal em espanhol mais consultado do mundo com mais de 11 milhões de usuários únicos registrados em setembro de 2016, de acordo com a comScore ${ }^{86}$. No Brasil, o El País é o sexto meio digital mais lido, também segundo a comsCore, com mais de 3,7 milhões de usuários únicos em agosto de 2016.

\footnotetext{
${ }^{86}$ http://elpais.com/elpais/2016/11/22/actualidad/1479853627_478107.html
} 
A publicação pertence ao maior conglomerado de mídia da Espanha, o Grupo PRISA, que ao longo da década de 2000 enfrentou fortes perdas financeiras em função da queda de circulação do jornal impresso. Em 2009, o grupo anunciou a integração das redações impressa e digital do jornal, que até então funcionava de forma independente, sob a tutela de outra empresa do grupo, a Prisacom. A união não foi apenas editorial, mas incluiu também todas as operações financeiras e administrativas das duas empresas. A proposta era criar uma empresa de conteúdos para múltiplas plataformas operando sob a marca El País, com cerca de 500 funcionários ao todo. "É a única forma viável para que dentro de 10 anos sigamos existindo, e para ajudar também a sobrevivência do resto da imprensa escrita", disse na época o conselheiro diretor da PRISA, Juan Luis Cebrián $^{87}$. Em 2011, o grupo anunciou o plano de reduzir 2.500 postos de trabalho ao todo, entre suas operações na Europa e América. No ano seguinte, 129 trabalhadores foram demitidos do El País, além de reduções salariais de $15 \%$ entre os que permaneceram no emprego ${ }^{88}$.

Na metade de 2015, o jornal lançou um aplicativo para Apple Watch. Em março de 2016, o El País anunciou uma remodelação de sua redação em Madri e um processo de transformação de sua estratégia para manter a liderança como meio espanhol digital de referência. Uma das principais mudanças envolveu a organização física da redação, onde agora no seu centro se localiza a área de controle e distribuição, na qual um grupo de editores, jornalistas, designers e analistas de audiência organizam a produção e a distribuição dos conteúdos frente a um telão com as principais manchetes dos jornais do mundo, as métricas do El País ao vivo e a visualização da página inicial do jornal no desktop e no smartphone ${ }^{89}$ (figura 17).

Ainda na redação, o El País criou uma área separada para editores que trabalham exclusivamente para a edição impressa, de forma semelhante ao que fez o NYT. Novos diretores adjuntos também foram nomeados, entre eles, David Alandete, diretor adjunto de produção e distribuição de conteúdos. David foi um dos entrevistados pela autora deste trabalho no mês de outubro de 2016, na sede do El País, em Madri. Além dele, também foram entrevistados Guillermo Castellanos, responsável por audiência e

\footnotetext{
${ }^{87} \mathrm{http}: / /$ sociedad.elpais.com/sociedad/2009/01/20/actualidad/1232406003_850215.html ${ }^{88} \mathrm{http}: / / \mathrm{www} . b b c . c o m / m u n d o /$ noticias/2012/10/121023_espana_elpais_crisis_prisa_dp

89 A disposição completa dos setores na redação do El País pode ser conferida no site http://elpais.com/especiales/2016/nueva-redaccion/.
} 
analítica digital, Pablo Delgado, diretor de desenvolvimento de produto digital, e Bernardo Marín Garcia, subdiretor de canais digitais.

Figura 17 - Tela inicial do aplicativo do El País

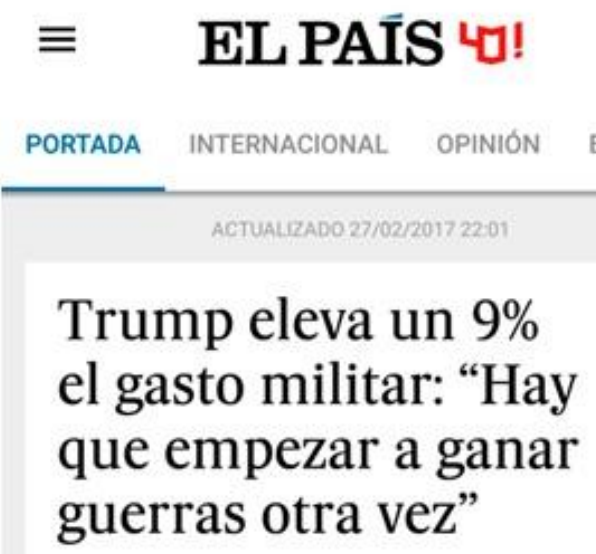

El presidente pone en marcha el mayor rearme en una década a costa de la ayuda al exterior y el medio ambiente

Javier Fernández e Iceta sellarán la paz la próxima semana en Madrid

Javier Fernández e iceta sellarán la paz la próxima semana en Madrid

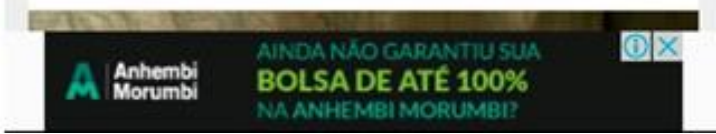

Os dispositivos móveis digitais correspondem a quase $60 \%$ do tráfego total do $E l$ País, de acordo com David Alandete, sendo que o crescimento de importância desses dispositivos ocorre há pelo menos quatro anos. Apesar disso, seu aplicativo para dispositivos móveis digitais não avança muito além no mínimo viável para um app de notícias tradicional. Dentro de nossa observação ${ }^{90}$ realizada com o primeiro instrumento de pesquisa, o produto do jornal espanhol possui somente uma categoria do Jornalismo Ubíquo implementada, a redistribuição, e também somente uma parcialmente implementada, a integração com o sistema. Fora essas, todas as outras cinco não aparecem no sistema, deixando-o atrás de outros exemplos internacionais como os que já mencionamos neste trabalho.

\footnotetext{
${ }^{90}$ A análise do aplicativo do jornal El País foi feita sob as mesmas condições técnicas já citadas e também durante o mês de fevereiro de 2017.
} 
O aplicativo do El País não possui geolocalização precisa ou envio de conteúdos relacionados ao local do usuário. Assim como outros casos já vistos em nossas análises, o conteúdo geolocalizado do app não vai além da opção que o usuário tem de escolher qual das edições disponíveis deseja ler e também de qual deseja receber alertas. Da mesma forma, a integração com outros dispositivos, assim como já visto, não vai além da possibilidade de compartilhamento de conteúdo via bluetooth.

O editor Guillermo Castellanos afirma que a geolocalização é um ponto difícil de se trabalhar, pois não se sabe até que ponto o usuário está interessado em receber alguma notícia relacionada ao lugar no qual ele se encontra no momento. Além disso, o jornal não capta dados nesse nível de precisão com relação ao posicionamento do leitor. O editor afirma que a preferência atual, do El País, é para que o usuário escolha quais notificações receber com relação aos assuntos que lhe interessam (embora a configuração de notificações não tenha tantas opções que permitam isso), também levando em consideração a privacidade do usuário e a validade em capturar tantos tipos de dados como fazem, por exemplo, alguns aplicativos de redes sociais online.

A navegação em camadas, num formato próprio para o dispositivo móvel digital, também não é explorada dentro do aplicativo do El País. Os textos são normalmente bastante longos, com links de hipertexto dispostos ao longo do conteúdo, de acordo com o formato desktop, sendo diferenciados apenas pela cor e pelo sublinhado, e poucos textos indicados ao final, relacionados ao conteúdo que é apresentado na tela. Dentro de alguns artigos, o aplicativo oferece um texto extra, destacado com fundo cinza e fonte menor, localizado no meio ou no final da matéria. Esse texto normalmente é algo relacionado ao contexto do artigo que se está lendo ou uma explicação extra sobre um ponto específico, no entanto, o usuário não tem a possibilidade de escolher não vê-lo, uma vez posto junto ao conteúdo ele aparecerá integrado ao layout, apenas diferenciado pela cor do fundo.

Pablo Delgado explica que o posicionamento do El País é aquele de entregar ao leitor todo o conteúdo disponível no jornal e não versões mais curtas ou diferentes, pensamento semelhante ao do NYT que objetivou entregar a "experiência completa" do jornal no dispositivo móvel digital. Segundo ele, o objetivo de tornar as experiências todas muito semelhantes é para que o usuário não tenha dificuldades em encontrar algum conteúdo quando acessa o jornal de outra forma. Sendo assim, se viu algo numa editoria específica no desktop, terá facilidade de encontrar o mesmo artigo posteriormente no 
aplicativo, pois os formatos são muito similares. "Estamos tentando tornar as experiências mais consistentes para que o usuário leia mais e consuma mais".

Não há também elementos personalizáveis no aplicativo do jornal espanhol. Não é possível definir quais editorias serão exibidas na tela principal, quais editorias serão enviadas nas notificações ou ainda que repórteres o usuário gostaria de seguir. A única possibilidade existente é a de "favoritar" alguns textos que ficam salvos para uma leitura posterior numa área de favoritos, tornando a funcionalidade semelhante à possibilidade de marcação para leitura posterior presente também em outros apps. Fora isso, não é exibido nenhum conhecimento acerca do que o usuário já consumiu através do sistema ou ainda uma oferta de conteúdos baseada nos hábitos de leitura.

A contextualização, assim como nos casos já vistos, não ocorre no aplicativo do El País. Também de forma semelhante, a integração ao sistema limita-se ao envio de notificações para o usuário que as visualiza a partir da tela inicial do smartphone. Vale destacar que, dentro das notificações, só se pode fazer as seguintes configurações: receber ou não os alertas e, se sim, escolher entre alertas de última hora, destaques do dia e avisos.

A redistribuição, mais uma vez de forma semelhante aos outros casos já mostrados, é o único ponto que se pode considerar como implementado dentro do aplicativo. A partir dele é possível compartilhar conteúdo com apps de redes sociais online, mensageiros instantâneos, e-mail, entre outros. Essa continuidade da implementação da redistribuição entre os aplicativos estudados nos leva a um apontamento: é possível que essa opção seja a mais fortemente adaptada à realidade atual e presente no aplicativo por mais vezes, em função da quantidade de audiência que as marcas jornalísticas recebem a partir desses serviços. Segundo Guillermo Castellanos, cerca de $30 \%$ da audiência do El País vêm do Facebook. Ou seja, deixar essa categoria de lado pode representar uma perda muito grande em compartilhamentos e, consequentemente, em audiência, o que não é uma opção viável para a maioria dos veículos.

Segundo Guillermo, há dois tipos de usuários que podemos observar a partir das métricas do público do El País. Um primeiro, que navega aleatoriamente pela rede e consome alguns artigos do jornal, a partir do navegador, sem permanecer necessariamente em contato futuro com a publicação. O outro tipo é um leitor mais fiel, que baixa o aplicativo no celular. Esse tipo de público é menor do que o primeiro, mas 
consome mais conteúdo e tem um tempo maior de contato e leitura. "Há mais pessoas acessando pelo navegador, mas a intensidade de consumo de conteúdo é maior no aplicativo", explica. As estratégias para engajar o público que vem de redes sociais passam pela organização do conteúdo, neste sentido, Guillermo afirma que se indica que todo texto tenha links, comentários, notícias relacionadas, galerias de fotos e vídeos, como elementos de retenção do leitor. Isso, no entanto, não é uma unanimidade entre os artigos, como vemos mais à frente na análise dos designs de navegação e interface do aplicativo.

Tabela 7 - Avaliação 1 do app do El País

\begin{tabular}{c|c|c|c}
\hline & Implementada & $\begin{array}{c}\text { Parcialmente } \\
\text { Implementada }\end{array}$ & Não Implementada \\
\hline I & & & $\mathrm{X}$ \\
\hline II & & & $\mathrm{X}$ \\
\hline III & & & $\mathrm{X}$ \\
\hline IV & $\mathrm{X}$ & & $\mathrm{X}$ \\
\hline V & & $\mathrm{X}$ & \\
\hline VI & & & \\
\hline VII & & & \\
\hline
\end{tabular}

Fonte: a autora

Gráfico 7 - Representação das categorias do JU no app do El País

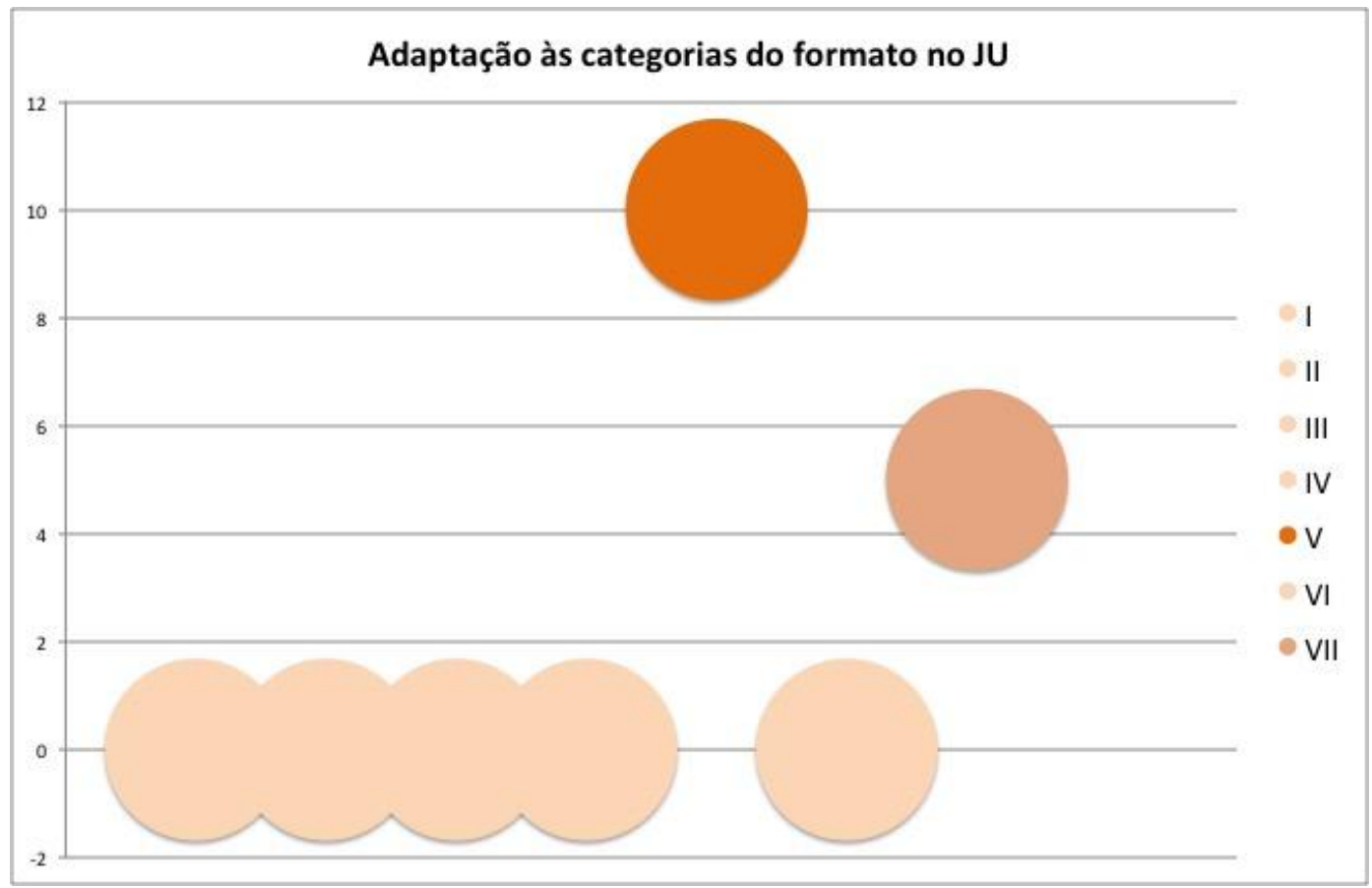

Fonte: a autora 
Como vemos na tabela e gráficos 7, acima, somente 1 categoria (14\%) das sete relacionadas ao Jornalismo Ubíquo pode ser considerada como implementada no aplicativo do El País. Igualmente, apenas uma (14\%) demonstrou estar parcialmente implementada, enquanto cinco $(72 \%)$ não apresentam nenhum tipo de implementação. Já dentre as 30 categorias presentes nas análises dos designs de navegação e interface do aplicativo do El País, somente 15 (50\%) puderam ser consideradas implementadas e quatro, parcialmente implementadas (13\%), resultado que coloca o serviço atrás dos outros já observados neste trabalho. Algumas categorias não implementadas no aplicativo são, de certa forma, básicas em muitos outros, o que acaba deixando-o numa posição desfavorável no comparativo. Entre elas, por exemplo, estão a ausência do campo de busca e também da possibilidade de fazer login no aplicativo. Além disso, a única opção de acessibilidade existente no sistema é a mudança do tamanho da fonte dos textos.

Ao final dos artigos longos, o aplicativo oferece em média dois ou três textos relacionados para que o usuário continue a leitura. Essas opções, no entanto, além de poucas são exibidas somente em texto, sem imagens ou qualquer outro tipo de elemento que possa atrair o leitor para continuar a navegação. Segundo o diretor Pablo Delgado, a escolha por apresentar somente dois textos indicados foi proposital, pois antes, com cinco sugestões, a página ficava mais pesada e também muito longa. Ele também afirma que após a troca, os resultados de continuação de leitura dentre a audiência cresceram. Esses textos sugeridos são determinados automaticamente, segundo Pablo, a partir de uma média entre os textos mais lidos naquele tema e os caminhos de leitura feitos por outros usuários que consultaram o mesmo artigo.

Outro aspecto possível de ser observado foi a não adaptação de certos conteúdos feitos para a versão web. Alguns gráficos interativos aparecem dentro das reportagens, entretanto, quando o usuário tenta tocar e interagir com o conteúdo ele não responde, atuando no conteúdo apenas como uma imagem estática, pois não foi adaptado corretamente da versão web para móvel (figura 18). 
Figura 18 - Infográfico não adaptado para o dispositivo móvel no app do El País

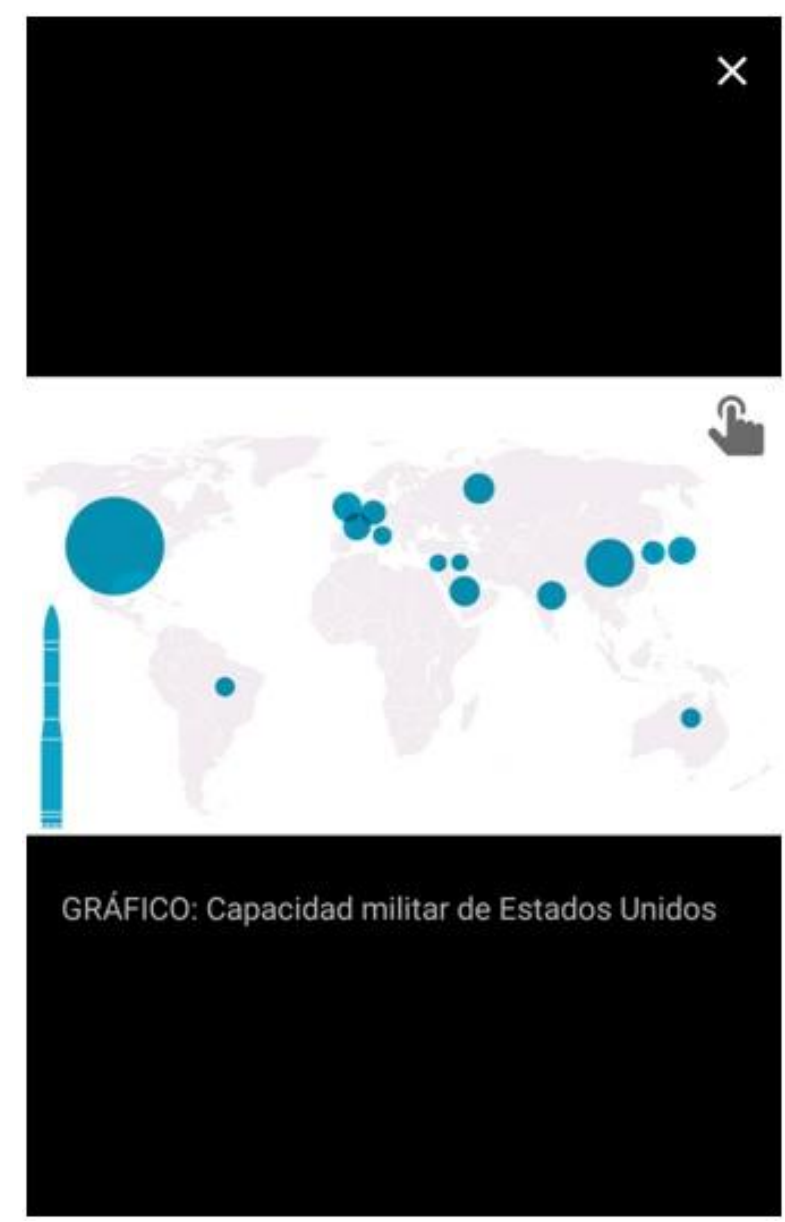

O menu do aplicativo do El País é o menor dentro todos os serviços analisados neste trabalho. Na edição espanhola (figura 19), são 12 opções, as editorias do jornal estão disponíveis somente no menu horizontal presente na tela principal, no menu vertical que é aberto pelo ícone no canto esquerdo superior da tela só aparecem os suplementos especiais do jornal, a seção de artigos favoritos do leitor e a opção de ajustes. Na edição americana, os itens são os mesmos da espanhola, já na catalã, são sete opções. Na edição brasileira são apenas três opções, tela inicial, favoritos e ajustes. Embora o menu pequeno seja um ponto positivo para o aplicativo, pois não demanda praticamente nenhuma rolagem do usuário, a escolha de deixar as editorias do jornal disponíveis somente no menu horizontal da tela principal acaba sendo ruim, pois esse mesmo тепи não fica disponível ao usuário em todas as telas, fazendo com que ele precise voltar ao início sempre que queira trocar de editoria ou então fique deslizando os artigos horizontalmente até chegar na seção desejada. 
Figura 19 - Menu do app do El País na edição espanhola

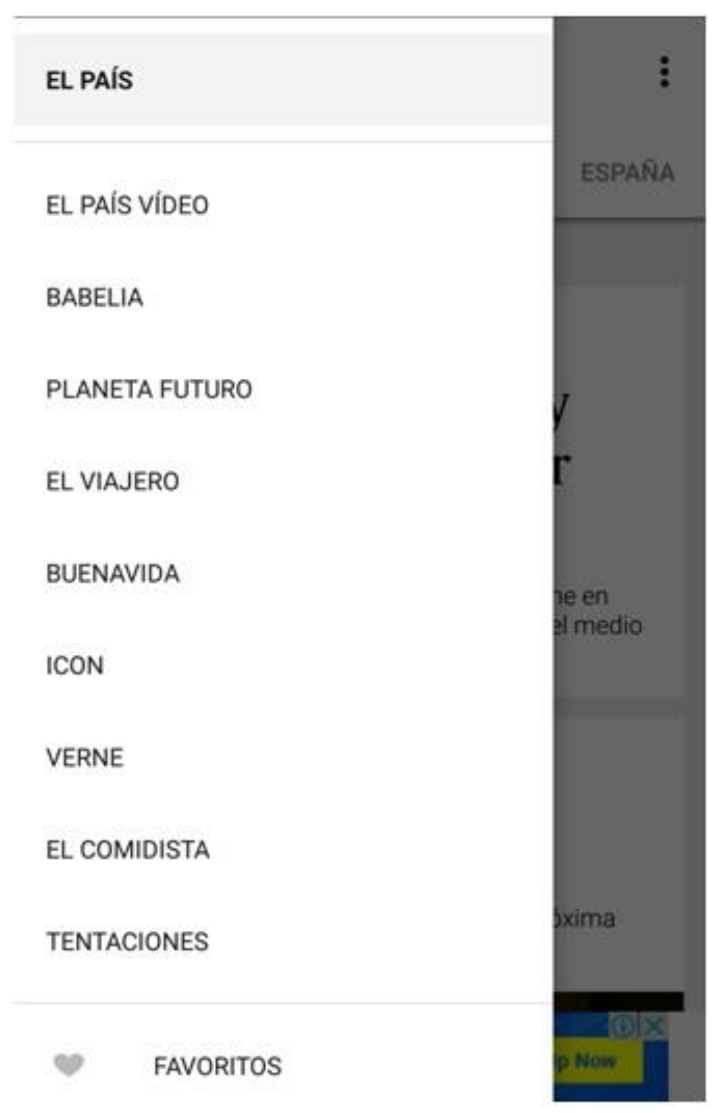

Uma das possíveis razões para esses pontos negativos no aplicativo do jornal é a não prioridade total dele dentro da estratégia móvel do veículo. De acordo com David Alandete, a página inicial do El País é desenhada pensando inicial e principalmente os dispositivos móveis digitais. O site é responsivo, mas ainda assim todas as páginas são formatadas primeiramente para o móvel, tanto as principais quanto as internas, de notícias. O sistema publicador do jornal possui testes de visualização para que o desenho da página seja visto e avaliado antes de ela ir ao ar e assim possa aparecer para o leitor da forma mais adequada possível. Segundo o diretor, o jornal investe igualitariamente no site e no aplicativo, sem priorizar um ou outro, acreditando que o acesso móvel pode vir tanto de quem possui o aplicativo como de quem acessa o conteúdo pelo navegador. "Não priorizamos um sobre o outro porque não cobramos pela informação. A nossa estratégia é não cobrar pelo conteúdo. É uma estratégia não cobrar porque o mercado latino-americano e espanhol é cultural não pagar pela informação e também é cultural não cobrar pela informação. Então acreditamos que o melhor é financiar a informação com publicidade". 
Tabela 8 - Análise do Design de Navegação do app do El País

\begin{tabular}{c|c|c|c}
\hline & Implementada & $\begin{array}{c}\text { Parcialmente } \\
\text { Implementada }\end{array}$ & Não Implementada \\
\hline $\mathbf{1}$ & $\mathrm{X}$ & & \\
\hline $\mathbf{2}$ & $\mathrm{X}$ & & \\
\hline 3 & $\mathrm{X}$ & & $\mathrm{X}$ \\
\hline $\mathbf{4}$ & & & $\mathrm{X}$ \\
\hline $\mathbf{5}$ & $\mathrm{X}$ & & \\
\hline 6 & $\mathrm{X}$ & & $\mathrm{X}$ \\
\hline $\mathbf{7}$ & & & $\mathrm{X}$ \\
\hline $\mathbf{8}$ & & & $\mathrm{X}$ \\
\hline $\mathbf{9}$ & & & $\mathrm{X}$ \\
\hline 10 & & $\mathrm{X}$ & \\
\hline 11 & & & $\mathrm{X}$ \\
\hline 12 & $\mathrm{X}$ & & \\
\hline 13 & & & \\
\hline 14 & & & \\
\hline 15 & & & \\
\hline
\end{tabular}

Fonte: a autora

Gráfico 8 - Representação da Análise do Design de Navegação no app do El País

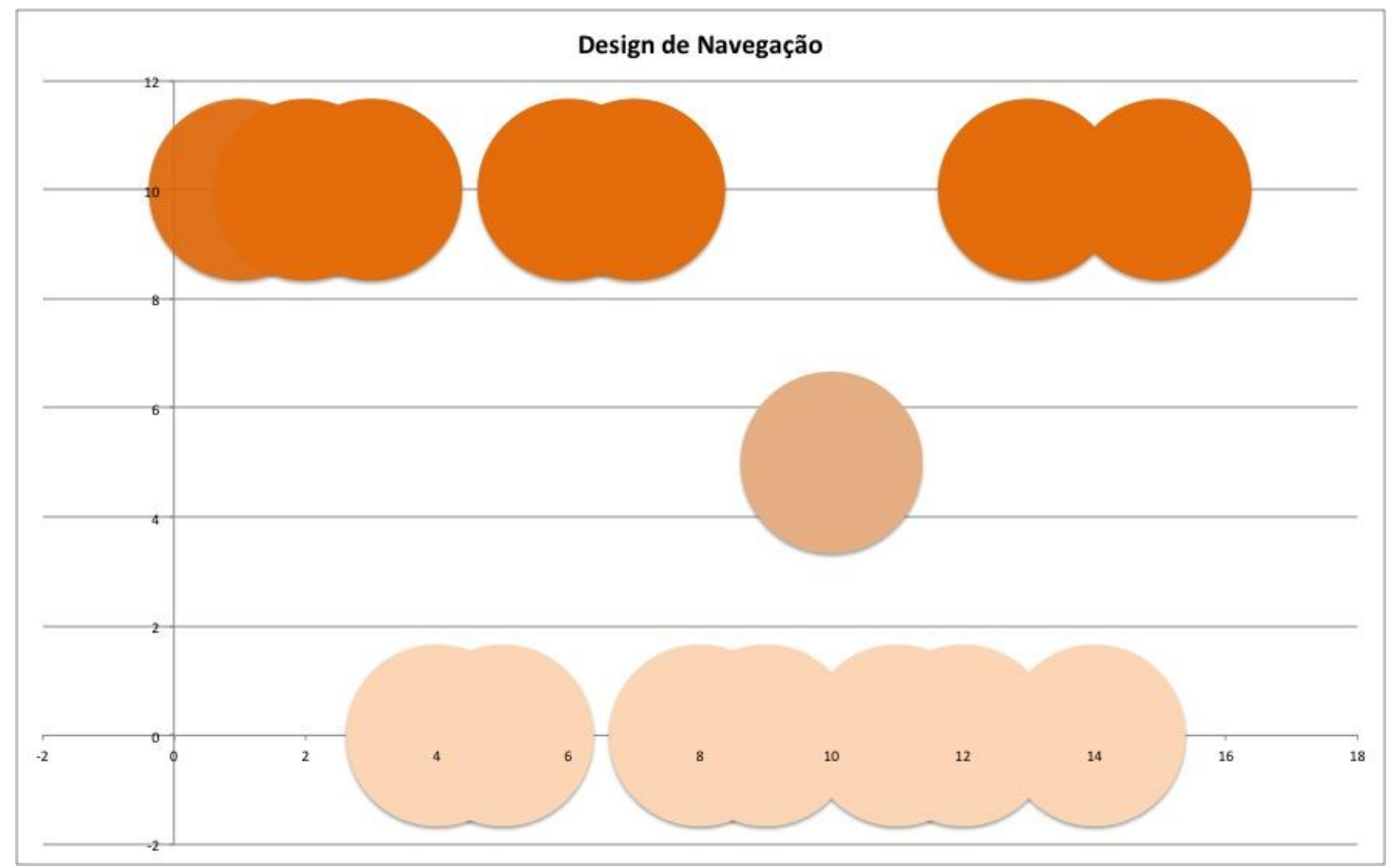

Fonte: a autora 
Tabela 9 - Avaliação do Design de Interface do app do El País

\begin{tabular}{|c|c|c|c|}
\hline & Implementada & $\begin{array}{l}\text { Parcialmente } \\
\text { Implementada }\end{array}$ & Não Implementada \\
\hline 16 & $\mathrm{X}$ & & \\
\hline 17 & $\mathrm{X}$ & & \\
\hline 18 & & & $\mathrm{X}$ \\
\hline 19 & $\mathrm{X}$ & & \\
\hline 20 & $\mathrm{X}$ & & \\
\hline 21 & & $\mathrm{X}$ & \\
\hline 22 & $\mathrm{X}$ & & \\
\hline 23 & & $\mathrm{X}$ & \\
\hline 24 & $\mathrm{X}$ & & \\
\hline 25 & & & $\mathrm{X}$ \\
\hline 26 & $\mathrm{X}$ & & \\
\hline 27 & & & $\mathrm{X}$ \\
\hline 28 & & & $\mathrm{X}$ \\
\hline 29 & $\mathrm{X}$ & & \\
\hline 30 & & $\mathrm{X}$ & \\
\hline
\end{tabular}

Fonte: a autora

Gráfico 9 - Representação da Análise do Design de Interface do app do El País

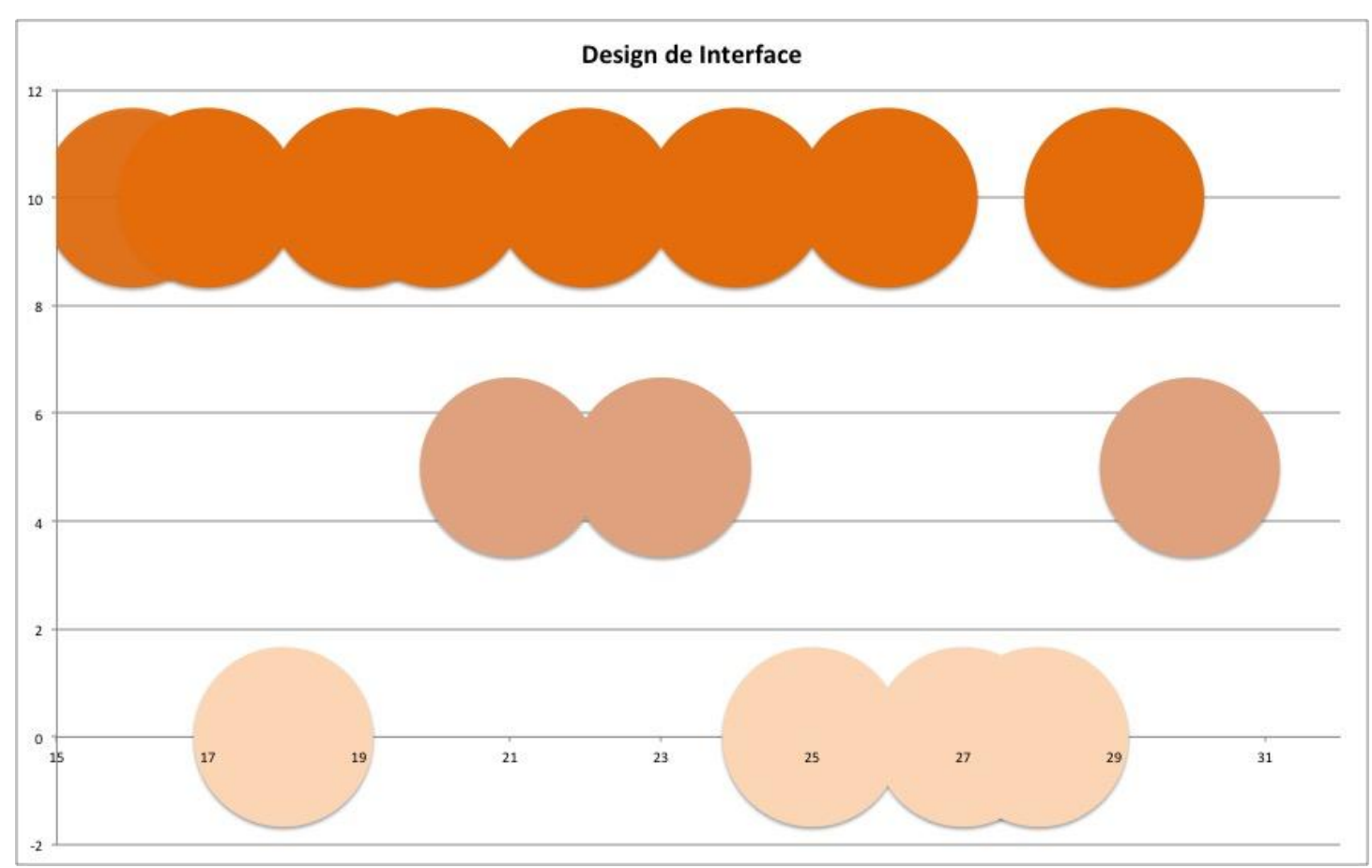

Fonte: a autora 
Outro aspecto que acaba sendo desagradável para o uso do aplicativo e que está diretamente relacionado à sua estratégia móvel é a publicidade (figura 20). Os anúncios são invasivos e excessivos ao longo da leitura. Um dos pontos que prejudica a experiência do usuário é o banner inferior de publicidade que acompanha o leitor em todas as telas do aplicativo, tanto na inicial quanto nos artigos internos e notícias. Além desse banner, também são utilizadas outras inserções de publicidade, em formato maior, e dessa vez, ao longo do texto. Essas peças são carregadas ao longo da leitura e da rolagem do conteúdo, o que faz com que em determinado momento o usuário esteja no meio da visualização e seja interrompido por uma publicidade sendo carregada. Esses anúncios não podem ser fechados e também não possuem um limite de exibição, conforme o tamanho do texto podem ser exibidos várias vezes, muitas delas, unindo-se ao banner já existente permanentemente e prejudicando ainda mais a experiência de uso.

Figura 20 - Publicidade no app do El País

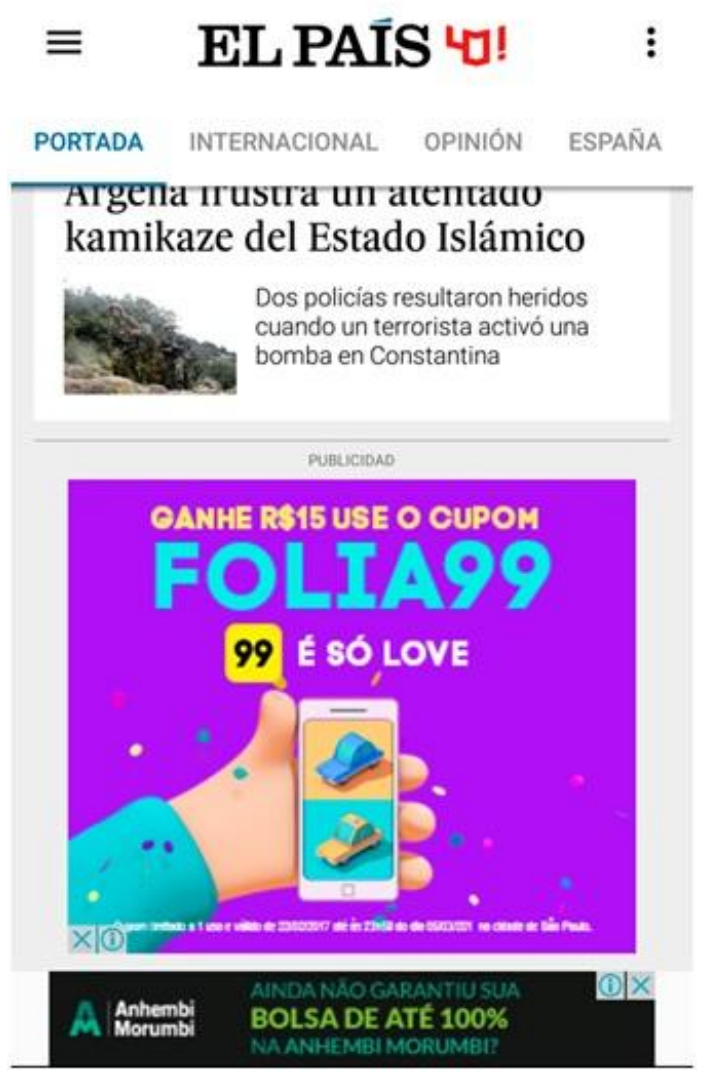

Pablo Delgado explica que por volta de 2008 e 2009, as empresas correram para lançar aplicativos jornalísticos porque era o movimento que se acreditava predominante naquele momento. Um tempo depois, a atenção se voltou para os navegadores, pois se 
via que as pessoas chegavam ao conteúdo dos jornais pelo Google e pelas redes sociais online, o que fazia com que fossem direcionadas para os sites. Hoje, segundo ele, a audiência do jornal no aplicativo não é a maior entre os dispositivos móveis digitais, no entanto, é a mais fiel. São cerca de $2 \%$ da audiência, mas que lê mais de $20 \%$ do conteúdo disponível.

O diretor explica que a partir de 2015, os aplicativos do El País para iOS e Android começaram a ser renovados para que a leitura fosse simples e fácil, e também para valorizar esse leitor mais fiel, em vez dos usuários que acessam pouco conteúdo eventualmente vindos de buscadores ou redes sociais online. Um dos exemplos citados por ele é a navegação horizontal, o usuário move-se entre editorias deslizando o conteúdo na horizontal tanto na tela inicial quanto dentro dos artigos. Antes também não havia vídeos disponíveis no aplicativo e agora há. "É muito difícil ganhar usuários nesta área, mas uma vez que se ganha eles serão muito fieis e consumidores de muito conteúdo", diz ele.

$\mathrm{Na}$ área de conteúdos imersivos, desde maio de 2016, o El País investe em produções especiais e exclusivas para realidade virtual. A primeira reportagem em realidade virtual publicada pelo periódico foi sobre as consequências do acidente nuclear de Fukushima. Depois disso, outra reportagem foi produzida em Aleppo e, em outubro, uma reportagem especial tratou do sumiço e assassinato de 43 estudantes mexicanos. $\mathrm{O}$ jornal investe também na área audiovisual com transmissões ao vivo permanentes em seus canais de redes sociais online a partir de um estúdio instalado dentro da redação.

Com relação aos itens 12 e 13 do quadro 1 deste trabalho, conforme também comentamos nas análises anteriores, o El País demonstra ser uma redação voltada para os dispositivos móveis digitais em primeiro lugar, e também com profissionais multicompetências. David Alandete afirma que a cultura e a filosofia que se busca para o El País é a do "mobile first", e isso fica claro na mudança realizada pelo jornal em sua redação e nas rotinas produtivas dos profissionais mencionadas antes, abrindo espaços para que todos tenham noções de temas específicos com relação à produção digital e também incluindo no espaço de trabalho profissionais como programadores, desenvolvedores, analistas de dados e especialistas em redes sociais online.

Segundo Guillermo Castellanos, para que essa mentalidade se espalhe há um processo de evangelização constante da redação. São realizadas, normalmente, duas vezes ao ano, para atualizar os profissionais dos processos e novidades da estratégia 
digital do jornal. Além disso, os jornalistas entram em contato com diversos profissionais para que tenham noções de design de experiência do usuário, SEO, entre outros, para que estejam integrados a todos os aspectos envolvidos na produção de conteúdo digital.

Pablo Delgado destaca, ainda, que é um trabalho constante fazer com que os jornalistas foquem o dispositivo móvel no momento da construção do conteúdo, isso porque, segundo ele, trabalham em computadores e, consequentemente, acabam focando-se mais nesses artefatos. O subdiretor Bernardo Garcia acredita que atualmente, os jornalistas estão presos a uma primeira fase, onde pensam no conteúdo que irão produzir como um texto e depois em como irão enriquecer esse texto com fotos, galerias, infográficos etc. Para ele, é preciso chegar a uma segunda fase, onde se pensará o conteúdo por si só, sem necessariamente partir de um texto com outros elementos, mas o conteúdo como uma unidade que se resolve em si mesma, podendo ter múltiplos formatos. "Esse é um caminho cultural muito grande, que precisa ir sendo interiorizado pelos redatores, não é algo fácil. Porque demos um salto do papel para a web, logo depois para o móvel e agora já não é mais somente isso. É um território novo que estamos criando todos os dias".

\subsection{O Estado de S. Paulo}

O jornal O Estado de S. Paulo, comumente chamado de Estadão, foi criado em 1875 com o nome de “A Província de São Paulo”. O nome atual só foi adotado em 1890 após a proclamação da República no Brasil. O jornal estreou na internet em 1995, data do início das operações do seu site. Em 2000, o portal estadao.com.br passou a publicar todo conteúdo produzido pelo Grupo Estado, que incluía além do jornal O Estado de S. Paulo, o extinto Jornal da Tarde e a Agência Estado. Em 2006, o jornal anunciou a integração das suas redações, unindo as equipes que produziam para o impresso e para o digital, e ainda a equipe do Jornal da Tarde. De acordo com a matéria publicada na época anunciando a integração, a objetivo da proposta era que o jornal impresso pudesse trazer análises e conteúdos mais aprofundados a partir das notícias que fossem publicadas no site. Em 2010, o jornal lançou seu aplicativo para iPad e em 2011 um aplicativo para o sistema operacional Android. Em 2014, foi implantado o paywall que restringe a quantidade de textos que podem ser lidos gratuitamente tanto no site quanto 
no aplicativo do jornal. O jornal também chegou a ter um produto vespertino exclusivo para smartphones e tablets, o Estadão Noite, que trazia resumos, repercussões e análises das principais notícias do dia. Esse produto, no entanto, deixou de ser aplicativo para virar uma newsletter no final de 2016. Agora, o usuário que deseja ter acesso a esse conteúdo se inscreve no site e recebe o material pelo seu $e$-mail.

Em 2015, a Huge, agência de produção digital norte-americana com escritórios no Brasil, foi contratada pelo Estadão para desenvolver o novo projeto móvel do jornal. A agência foi responsável pelo design e pela pesquisa para a construção dos novos produtos, a parte tecnológica de desenvolvimento ficou a cargo do próprio jornal. $\mathrm{O}$ resultado foi a produção de um aplicativo móvel e também o redesenho da página do jornal. Na prática, os dois oferecem o mesmo tipo de conteúdo e são formatados da mesma maneira: o primeiro contato do usuário se dá com a tela inicial que informa uma média de 12 principais destaques selecionados pelo jornal por importância a fim de que o leitor tenha ali todo o material que precisa para ficar bem informado naquele momento (figura 21). Essa semelhança não ocorre por acaso, um dos objetivos declarados do projeto era de "resgatar a experiência de leitura do jornal impresso e projetá-la no ambiente digital".

Figura 21 - Aplicativo do Estadão para smartphones

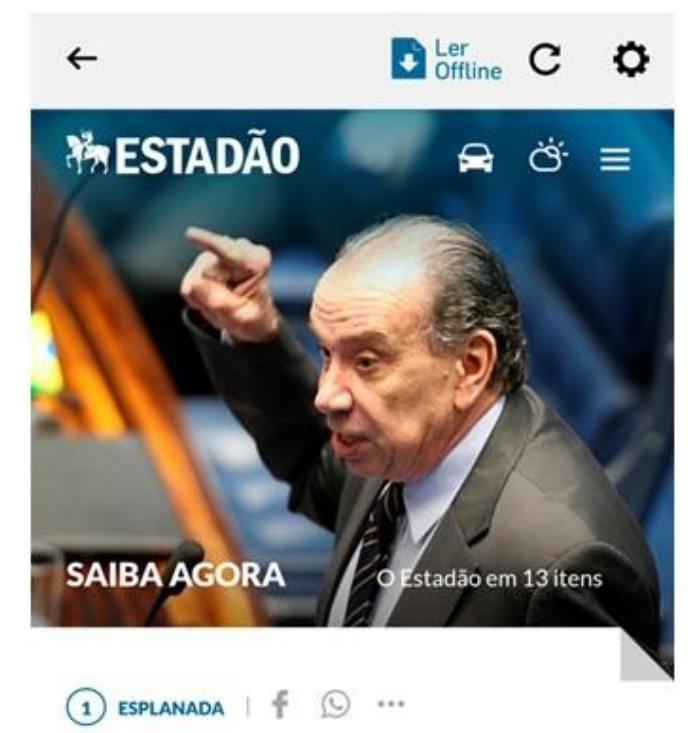

\section{Temer escolhe senador Aloysio Nunes, do PSDB, para as Relações Exteriores}


Luis Fernando Bovo, editor executivo de conteúdos digitais, entrevistado pela autora para a realização deste trabalho, afirma que o que motivou a renovação foi a quantidade de acessos ao jornal que já é maior via dispositivos móveis digitais do que em desktops, embora o número de page views ${ }^{91}$ ainda seja maior nos computadores pessoais. "A gente fez o 'mobile first' de verdade. Criamos o site móvel, encapsulamos isso num aplicativo com mais alguns 'features' e por último veio o site desktop", explica. Segundo ele, um dos elementos que justifica a proximidade entre os produtos é a quantidade de acessos diretos que o Estadão tem. Enquanto muitas marcas recebem a maioria do tráfego móvel via redes sociais online, Luis Fernando Bovo afirma que a maior parte dos acessos móveis e desktop do Estadão é de pessoas que entram diretamente no site do jornal ou no aplicativo, sem terem sido encaminhadas por algum link de um serviço terceiro.

No mesmo período da mudança nos produtos para o leitor, o jornal também mudou o sistema publicador de conteúdos. Agora, cada editoria é responsável por editar a sua área na página principal do jornal e esse desenho é automaticamente exibido. Isso, no entanto, não significa que não há edição humana na página principal. Os editores podem desativar essas opções automáticas e redesenhar a interface a partir dos critérios jornalísticos que possuem e dos conteúdos que desejam enfatizar. Essa edição é igualmente realizada para o que aparece na tela inicial do aplicativo. Apesar de todo esse processo de renovação, o aplicativo do Estadão fica atrás dos outros observados em nossa análise quando aplicamos a ele os instrumentos que utilizamos para avaliar o produto, como pode ser visto nas tabelas e gráficos a seguir.

\footnotetext{
91 Page view em tradução literal significa visualização de página. A expressão é utilizada para definir a métrica de quantas vezes uma página na web foi visualizada num determinado navegador.
} 
Tabela 10 - Avaliação 1 do app do Estadão

\begin{tabular}{c|c|c|c}
\hline & Implementada & $\begin{array}{c}\text { Parcialmente } \\
\text { Implementada }\end{array}$ & Não Implementada \\
\hline I & & $\mathrm{X}$ & $\mathrm{X}$ \\
\hline II & & & $\mathrm{X}$ \\
\hline III & & $\mathrm{X}$ & \\
\hline IV & & $\mathrm{X}$ & $\mathrm{X}$ \\
\hline V & & $\mathrm{X}$ & \\
\hline VI & & & \\
\hline VII & &
\end{tabular}

Fonte: a autora

Gráfico 10 - Representação das categorias do JU no app do Estadão

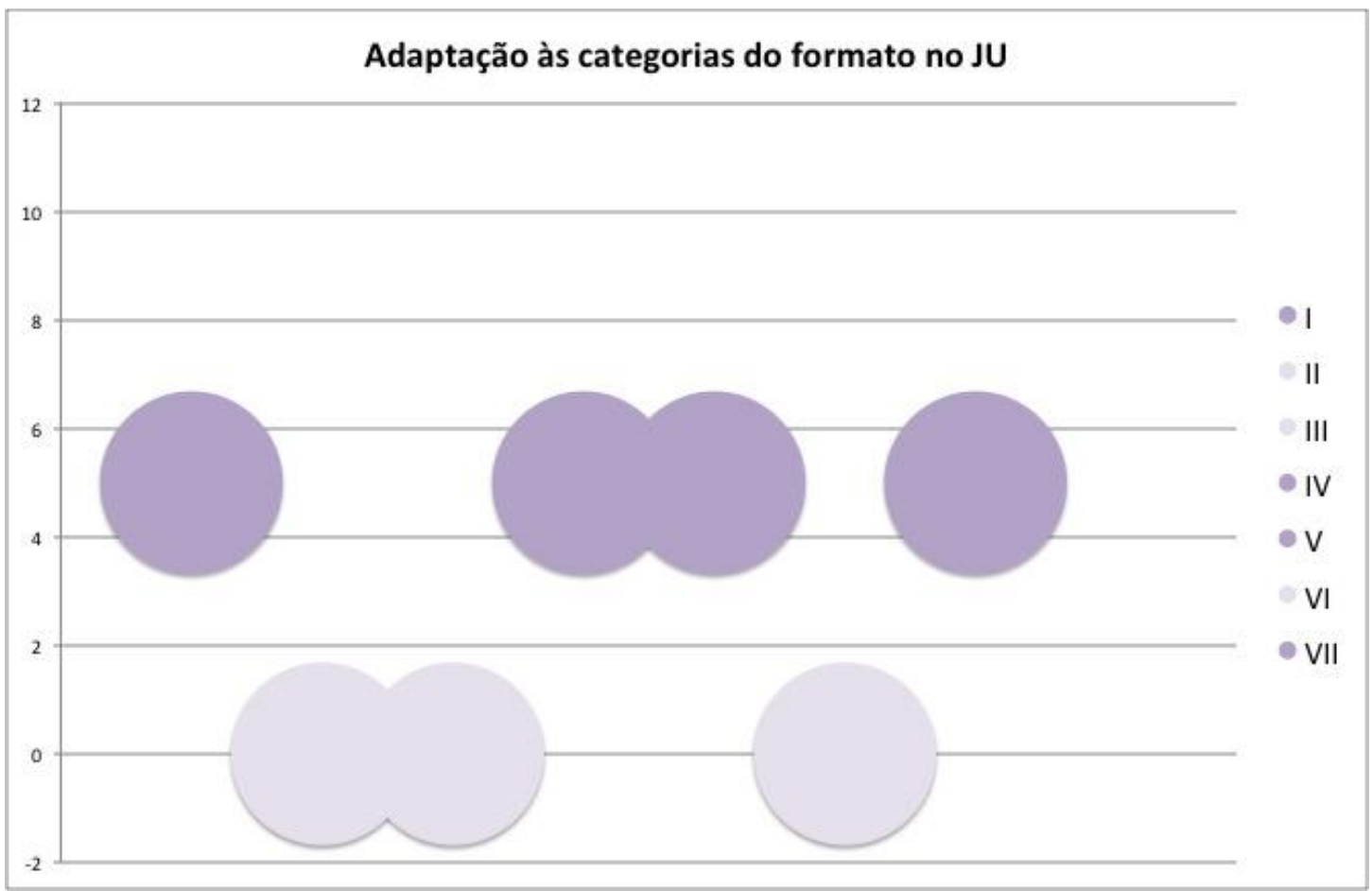

Fonte: a autora

Em se tratando das categorias do Jornalismo Ubíquo, o aplicativo do Estadão não demonstrou ter nenhuma delas realmente implementada. Há somente quatro categorias (57\%) parcialmente implementadas e três (43\%), não implementadas. A primeira delas, geolocalização, segue a mesa linha de todos os outros aplicativos já observados e mencionados. O Estadão é capaz de enviar notificações geolocalizadas, ou seja, se um conteúdo se refere ao Estado de Minas Gerais, no Brasil, por exemplo, o sistema é capaz 
de enviar o alerta somente para os leitores que se encontram naquele local. No entanto, esse é o limite do que pode ser feito a partir da localização dos usuários. Não há possibilidade de enviar conteúdos com informação geográfica mais precisa e também não há possibilidade de que o próprio usuário possa definir que conteúdos quer receber baseado na localidade a qual se referem.

O editor Luis Fernando Bovo diz acreditar que o pouco desenvolvimento dessa característica é culpa da falta de pessoal para se dedicar a esse tema. Segundo ele há tecnologia e há conhecimento sobre o usuário o suficiente, no entanto, não há pessoal suficiente para ligar com o tamanho da quantidade de dados que seria necessário gerenciar para fazer funcionar bem um sistema baseado em geolocalização. "Com um grupo de pessoas seria possível fazer isso. Seria geolocalizar as informações que temos publicadas e disparar isso para quem está próximo ou interessado. O problema é que faltam pessoas". Além disso, o editor também comenta que é preciso ter cuidado para não correr o risco de incomodar o leitor com o envio de informações, na medida em que o usuário que tem o aplicativo instalado no smartphone é muito importante para a empresa, pois é mais fiel e engajado, fazendo com que não se possa correr o risco de perdê-lo.

A conexão entre dispositivos no Estadão aparece como não implementada porque o aplicativo não se conecta a outros artefatos nem mesmo na possibilidade de enviar informações por bluetooth. Esse motivo, inclusive, é um dos que faz com que a redistribuição seja considerada parcialmente implementada. Em comparação com outros apps, o do Estadão é muito mais limitado com relação ao número de serviços que se conectam para o compartilhamento do conteúdo. É possível enviar artigos pelo Facebook, WhatsApp, Google Plus, Twitter, LinkedIn e E-mail, enquanto outros aplicativos se conectam a mais serviços de mensagem e compartilhamento, além do uso de bluetooth.

Também semelhante aos casos já expostos sobre outros aplicativos, a contextualização não está implementada no Estadão. A possibilidade de se adaptar ao contexto do usuário enviando conteúdos de acordo com a sua rotina e movimentação não é aproveitada pelo aplicativo, provavelmente pelo mesmo fator do não uso da geolocalização: falta de pessoal. As empresas de comunicação em geral, no Brasil, vêm sendo afetadas pela crise da indústria e pela própria crise financeira do país, o que faz 
com que em vez se criarem investimentos, se enxugue a redação e os postos de trabalho cada vez mais.

No que toca à integração com o sistema, mais uma vez seguindo a linha do que já foi tratado, no Estadão, essa se limita ao uso de notificações. Essas, por sua vez, estão implementadas de forma menos satisfatória, pois o usuário só tem a opção de escolher se quer ou não receber os alertas, não é possível escolher quais editorias receber ou em quais momentos do dia se prefere receber os alertas. Além disso, também não é possível configurar as notificações, a fim de definir se elas terão som, vibração ou nenhum deles, todos os alertas enviados pelo Estadão emitem um aviso sonoro e vibram, não sendo possível trocar essa configuração, o que faz com que muitas vezes os envios sejam confundidos com mensagens pessoais ou então emitam ruídos em momentos inapropriados.

Como exposto anteriormente, a formatação do aplicativo do Estadão é muito semelhante, se não igual, ao desenho do site do jornal, o que logicamente faz com que a navegação em camadas não esteja explorada no sistema. Os artigos são exibidos no mesmo tamanho e formato que estão construídos também para exibição no site, com uso de imagens (que não têm opção de ser ampliadas) no meio do artigo e links também inseridos ao longo do texto. Isso se dá, provavelmente, por uma opção do jornal em igualar as experiências entre os produtos disponíveis. Bovo explica que os leitores do jornal demonstraram interesse em ter acesso ao produto por completo nos dispositivos móveis. Segundo ele, ao ouvir os assinantes e consumidores do Estadão, percebeu-se que o ideal seria manter a experiência do jornal impresso nas outras plataformas, pois os leitores demonstraram querer ter acesso ao conteúdo por completo, fazendo com que o periódico seguisse uma linha semelhante ao proposto pelo El País e pelo NYT.

O que o jornal oferece como possível elemento de um princípio de camadas para a leitura do usuário é a opção "Continuar lendo" ao final de um artigo (figura 22). Essa opção aparece quando o leitor abre uma notícia e leu o conteúdo até um determinado ponto, a partir dali, para continuar a leitura ele precisa tocar nessa opção e então visualizar o conteúdo completo. Esse recurso poderia ser considerado um princípio de uso de camadas de importância, pois o leitor pode ter contato com uma primeira parte do texto e só se aprofundar a partir dali se tiver interesse. Esse recurso está disponível em todas as plataformas do Estadão, incluindo o site desktop, ou seja, não foi pensando especificamente para o sujeito que está consumindo a partir do dispositivo móvel digital. 
Figura 22 - Recurso para continuar a leitura no app do Estadão

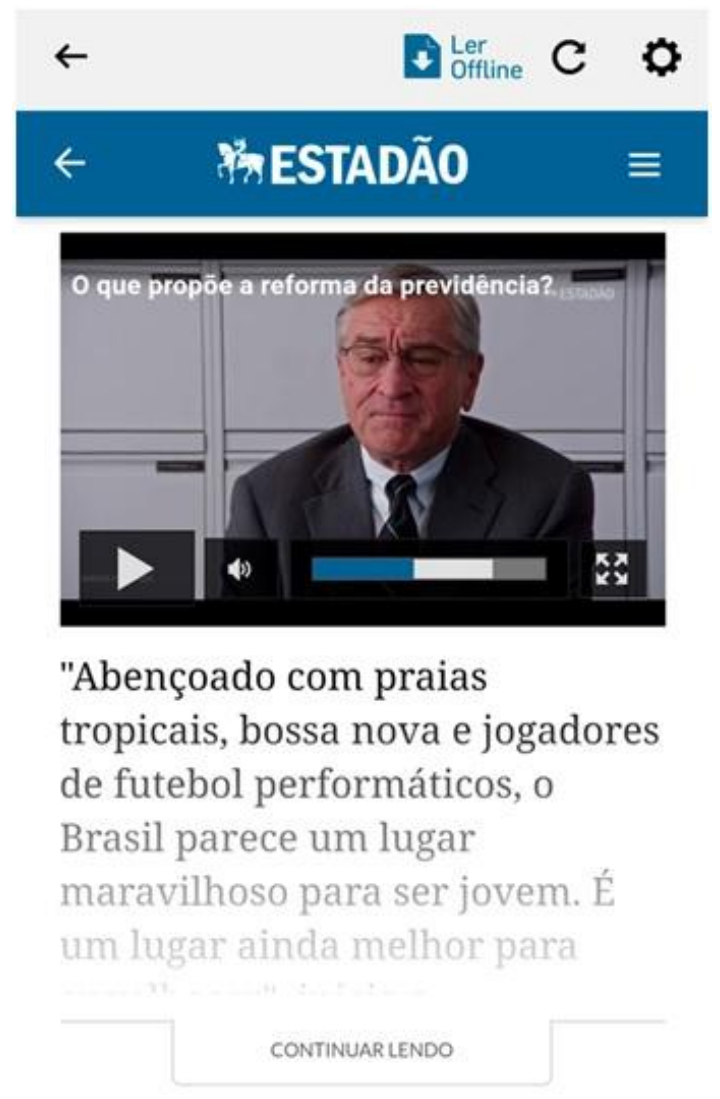

Bovo também explica que foi percebido que o recurso de personalização não era tão utilizado pelos leitores, o que fez com que o jornal parasse de investir tanto nessa possibilidade, por crer que essa falta de engajamento dos usuários nesse recurso representava um desejo de receber efetivamente a curadoria de temas feita pelos jornalistas da empresa. Apesar disso, essa opção existe no aplicativo. É possível personalizar as editorias que o usuário deseja que apareçam na sua tela principal, es sa opção, no entanto, é muito difícil de ser encontrada. É preciso acessar o ícone da previsão do tempo ou o do trânsito na tela inicial e, uma vez dentro de uma dessas opções, é preciso tocar no menu do lado direito e nele acessar a opção "Personalizar minha Home". Em nenhuma outra tela essa opção está disponível o que faz com que exista aí um problema de inconsistência nas interações, pois, na tela inicial do aplicativo há um menu disponível que é aberto a partir do ícone do lado superior direito. Quando se acessam os conteúdos de trânsito e da previsão do tempo, o mesmo ícone do lado superior direito dá acesso a outro menu, dessa vez com a possibilidade de personalização. Ou seja, são dois menus diferentes acessíveis em locais diferentes, mas a partir do mesmo tipo de interação e no mesmo ponto de acesso na tela, fato que 
prejudica a coerência e consistência das interações dentro do aplicativo. Nas imagens 23 e 24 abaixo é possível ver os dois exemplos.

Figura 23 - Menu do app do Estadão acessível pela tela inicial

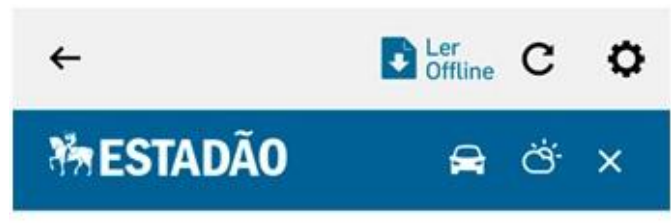

Q Encontre noticias, assuntose pes:

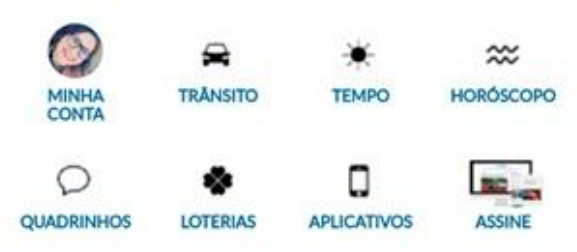

Opiniåo > Politica >

Economia \& Negócios > Brasil >

Figura 24 - Menu do app do Estadão acessível em telas secundárias

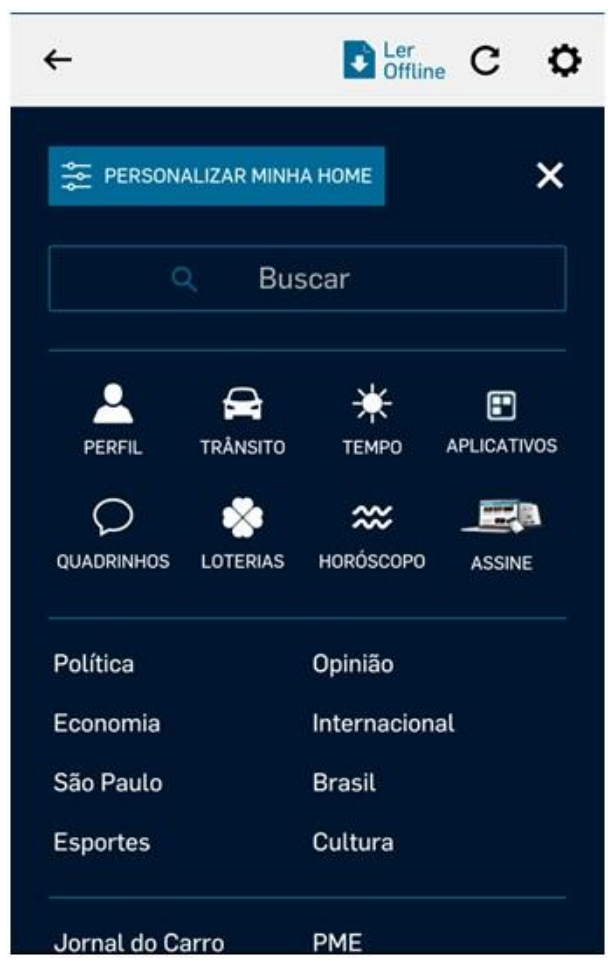


Outro exemplo de problema de consistência nas interações propostas pelo aplicativo do Estadão, e aqui já adentrando nossa análise nos itens elencados pelo segundo instrumento de observação, é o ícone de voltar, disponível no app. Como pode ser visto na figura 23, a tela inicial do aplicativo já traz um ícone de uma seta voltada para o lado esquerdo, o que normalmente é compreendido no padrão de interações como um ícone de retorno à tela anterior, no entanto, ter um ícone de retorno na tela que é a primeira do aplicativo não faz muito sentido. O que poderia fazer sentido é esse ícone funcionar como "voltar" uma vez que o usuário está dentro de um artigo, numa tela secundária do aplicativo. O problema é que quando se acessa um conteúdo interno o aplicativo cria um segundo ícone de retorno na tela, abaixo do primeiro, como pode ser visto na figura 24. Para piorar, nenhum dos dois apresenta um padrão de funcionamento. Uma vez dentro de um artigo, algumas vezes, um deles funciona como uma ação de retorno, ou então, há casos em que nenhum funciona para voltar à tela inicial, sendo necessário tocar sobre a palavra "Estadão" na parte central do topo da tela.

Alguns outros pontos, além da inconsistência nas interações, também causam desconforto ao usuário do aplicativo do Estadão. Um deles é sua instabilidade. Muitas vezes ao tocar sobre um conteúdo na tela inicial o usuário é direcionado para uma tela de erro (figura 25, a seguir). Algumas vezes, nessa tela, nenhuma ação funciona, nem o ícone de retorno, nem o direcionamento para a página inicial a partir do logotipo do jornal, fazendo com que seja necessário que o usuário feche o aplicativo e abra novamente para continuar a leitura. Outras vezes, o botão de retorno funciona e é possível seguir a leitura. Esse erro é, aparentemente, aleatório, ocorrendo em textos de diversas editorias, não ficando claro se é um possível impedimento relacionado ao paywall e seu limite de notícias para serem lidas gratuitamente, pois outros textos seguem podendo ser abertos normalmente após o erro aparecer na tela. 
Figura 25 - Tela de erro no aplicativo do Estadão

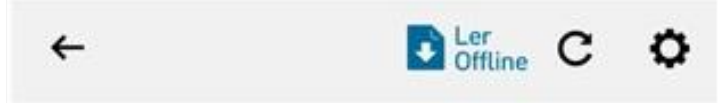

\title{
Access Denied
}

\author{
You don't have permission to access \\ "http://economia.estadao.com.br/noticias/geral,c \\ volta-a-r-3-05-depois-de-quase-dois- \\ anos, $70001677334^{\prime \prime}$ on this server. \\ Reference \#18.36dc00c9.1487887656.66e4bc
}

Mais um ponto problemático no produto é a velocidade de carregamento. O aplicativo do Estadão é lento se comparado aos outros desta análise, são em média 12 segundos para carregar a tela inicial (para comparação, o aplicativo do NYT nunca demorou mais do que 3 segundos para executar a mesma ação). Além de levar um tempo considerável para exibir a tela inicial completa em sua abertura, o aplicativo demora esse mesmo tempo para exibi-la novamente quando o usuário retorna de uma página interna. Outro ponto que deixa a lentidão perceptível é o tamanho da tela inicial, que possui uma rolagem muito extensa. Ao contrário dos outros aplicativos e do padrão de interações desse estilo na indústria, o Estadão não oferece rolagem horizontal entre editorias, ao contrário disso, as seções vão sendo exibidas à medida que se desce na rolagem vertical. Essa exibição, no entanto, leva um tempo para ser carregada, pois só inicia quando o usuário chega ao final da tela em que está, fazendo com que seja necessário esperar o carregamento para que se continue a leitura. 
Tabela 11 - Análise do Design de Navegação do app do Estadão

\begin{tabular}{c|c|c|c}
\hline Implementada & $\begin{array}{c}\text { Parcialmente } \\
\text { Implementada }\end{array}$ & Não Implementada \\
\hline $\mathbf{1}$ & & $\mathrm{X}$ & \\
\hline $\mathbf{2}$ & & $\mathrm{X}$ & $\mathrm{X}$ \\
\hline $\mathbf{3}$ & & $\mathrm{X}$ & $\mathrm{X}$ \\
\hline $\mathbf{5}$ & & & $\mathrm{X}$ \\
\hline $\mathbf{6}$ & $\mathrm{X}$ & $\mathrm{X}$ & $\mathrm{X}$ \\
\hline $\mathbf{7}$ & & $\mathrm{X}$ & \\
\hline $\mathbf{8}$ & & $\mathrm{X}$ & \\
\hline $\mathbf{9}$ & & & $\mathrm{X}$ \\
\hline 10 & & $\mathrm{X}$ & $\mathrm{X}$ \\
\hline 11 & & & \\
\hline 12 & & & \\
\hline 13 & & & \\
\hline 14 & & & \\
\hline 15 & & & \\
\hline
\end{tabular}

Fonte: a autora

Gráfico 11 - Representação da Análise do Design de Navegação no app do Estadão

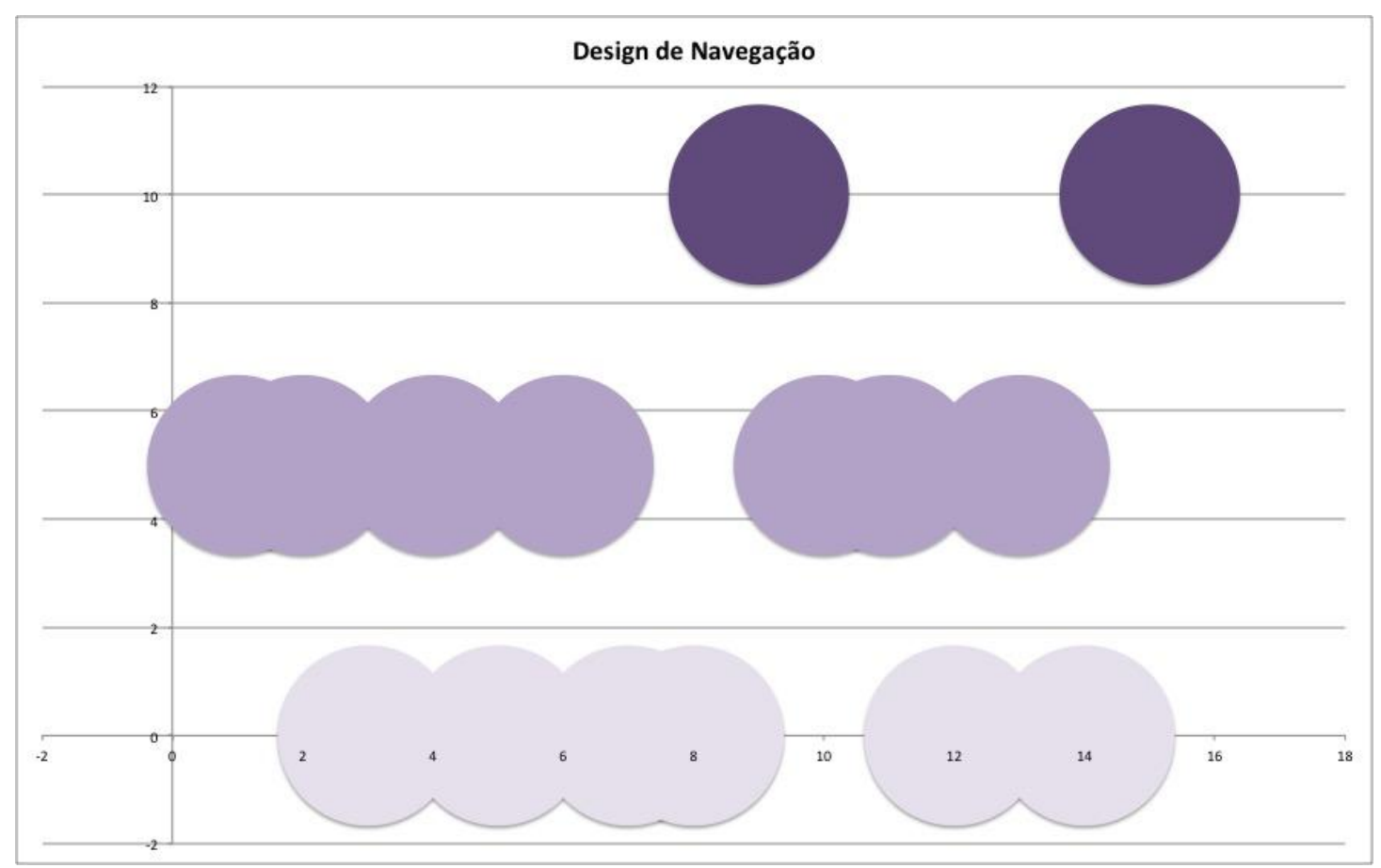

Fonte: a autora 
Tabela 12 - Avaliação do Design de Interface do app do Estadão

\begin{tabular}{c|c|c|c}
\hline & Implementada & $\begin{array}{c}\text { Parcialmente } \\
\text { Implementada }\end{array}$ & Não Implementada \\
\hline 16 & $X$ & & \\
\hline 17 & $X$ & $X$ & \\
\hline 18 & $X$ & & \\
\hline 19 & $X$ & & $X$ \\
\hline 20 & $X$ & & \\
\hline 21 & & & $X$ \\
\hline 22 & & & $X$ \\
\hline 23 & & & $X$ \\
\hline 24 & & & $X$ \\
\hline 25 & & & $X$ \\
\hline 26 & & & $X$ \\
\hline 27 & & & $X$ \\
\hline 28 & & & $X$ \\
\hline 29 & & & $X$ \\
\hline 30 & & & \\
\hline
\end{tabular}

Fonte: a autora

Gráfico 12 - Representação da Análise do Design de Interface do app do Estadão

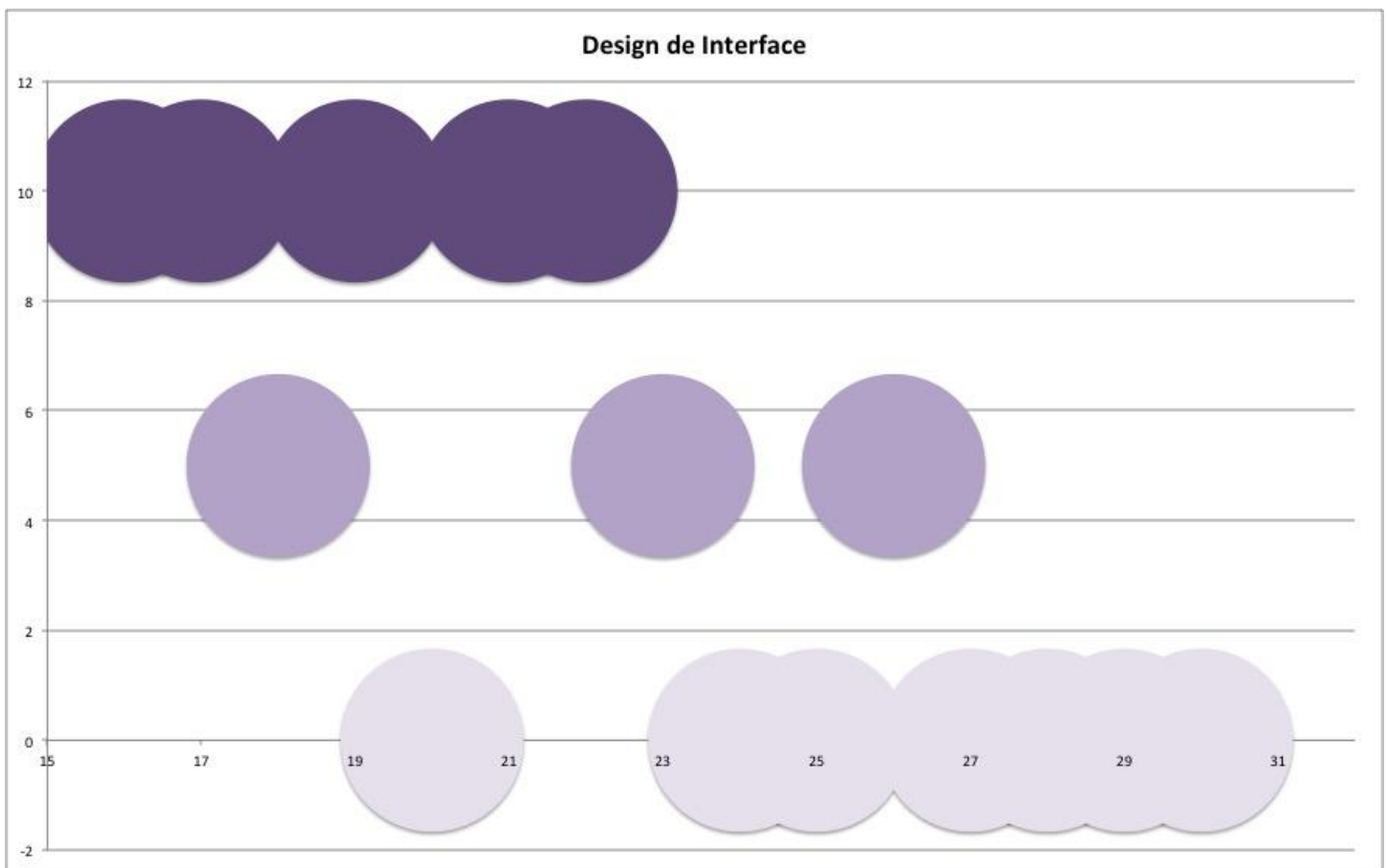

Fonte: a autora 
Como se pode perceber a partir das tabelas e gráficos 11 e 12, acima, o aplicativo do Estadão tem apenas sete (23\%) categorias de design de navegação e interface implementados, o que o coloca numa posição abaixo de todos os outros produtos observados neste trabalho. Os elementos parcialmente implementados totalizam 10 (33\%) e a maioria demonstra estar não implementada, totalizando 13 (44\%). Ainda dentro desses aspectos de análise vale mencionar mais alguns problemas encontrados. A publicidade é um deles. Em alguns dias (acreditamos que apenas quando esse tipo de ação é vendida pelo departamento comercial), o aplicativo do jornal apresenta um banner publicitário em formato de pop-up logo na abertura do serviço, antes mesmo de a tela inicial estar totalmente carregada. Esse tipo de publicidade é aquele que "salta" na tela e sobrepõe o restante do conteúdo, não permitindo a navegação até que ele seja fechado pelo usuário.

Além disso, ao final de cada artigo, o aplicativo mostra um conjunto de links sugeridos, esses, no entanto, não estão relacionados ao tema do texto que está sendo lido, mas sim sendo compostos de links patrocinados, publicados em sites externos ao do jornal e com conteúdo de caráter, muitas vezes, duvidoso, como pode ser visto na figura 26, abaixo. Esses artigos promovidos são exibidos com uma interface diferente, mas não são direcionados para o navegador sendo abertos dentro do próprio aplicativo. Todavia uma vez dentro deles, o botão de retorno não funciona e o usuário não consegue voltar à tela inicial, sendo obrigado, mais uma vez, a reiniciar o aplicativo para seguir sua leitura. Sendo assim, esses links ao final do texto não oferecem um caminho para que o leitor siga navegando e se engaje com o conteúdo, muito pelo contrário, ele é direcionado a um artigo de terceiros, não checado e, possivelmente, não jornalístico, e quando deseja voltar, o ícone que deveria levá-lo de volta não funciona. Para seguir navegando, o usuário precisa ignorar esses links patrocinados e aguardar o lento carregamento da matéria seguinte publicada na editoria, que é exibida na sequência do texto que ele está lendo. 
Figura 26 - Links patrocinados exibidos ao final dos artigos no app do Estadão
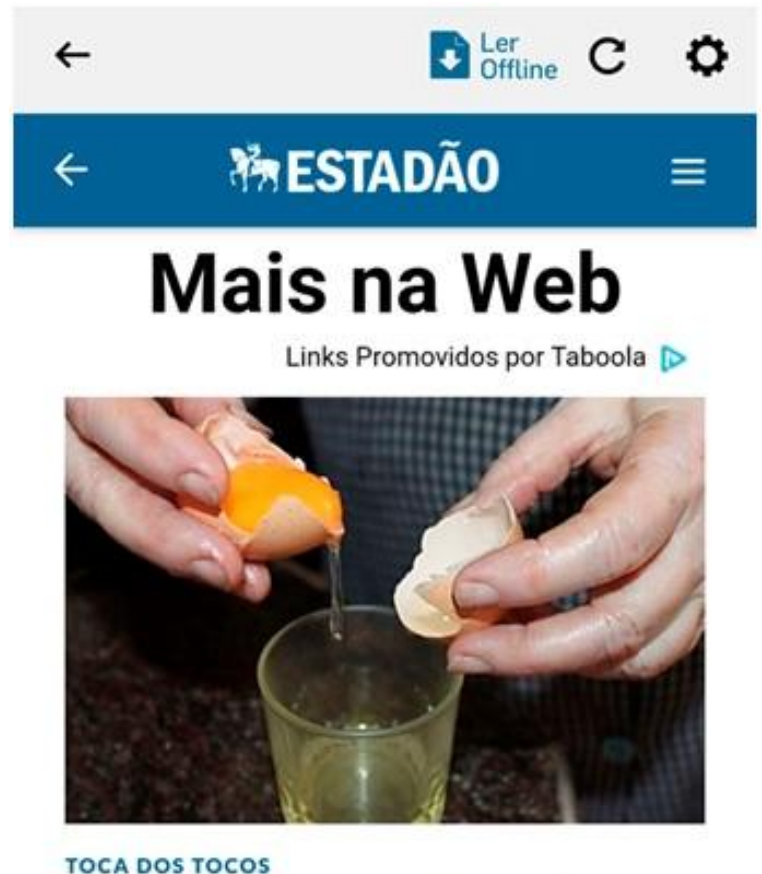

\begin{abstract}
Descoberto um energético natural para o desempenho masculino.
\end{abstract}

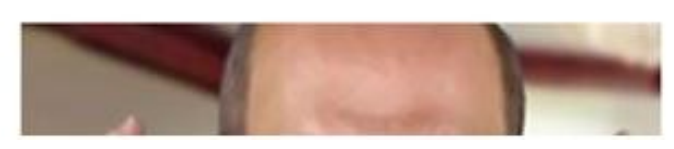

Outros pontos que valem também ser mencionados aqui é que o aplicativo não possui opções de acessibilidade. Não é possível aumentar o tamanho da letra ou modificar o brilho da tela, por exemplo. Os vídeos também não possuem opção para serem maximizados е о тепи (aquele que abre na tela inicial do aplicativo) possui o recorde de 53 opções.

Apesar desses problemas elencados e das poucas categorias implementadas de acordo com nossa análise, o Estadão busca a conjuntura de uma redação "mobile first" e também a propagação dos profissionais multicompetências. Segundo o editor Luis Fernando Bovo, toda redação se envolve na edição do produto feito para dispositivos móveis digitas. Além disso, há cursos e apresentações para que a lógica "mobile first" se espalhe para todos os profissionais, na medida em que, eventualmente, todos se envolverão, em algum momento, com produção para smartphones e tablets. Vale ressaltar também, que a formatação da redação do Estadão se assemelha com a do $E l$ País com uma área central composta por editores que selecionam os conteúdos 
destacados e sua distribuição, bem como com um telão que mostra a audiência ao vivo e a disposição dos conteúdos nas diferentes interfaces de plataformas onde ele é visualizado. Na época de nossa entrevista, o Estadão se preparava para também adotar a postura de ter uma área exclusiva e separada para a condução da edição impressa, assim como ocorre no NYT e no El País, o que segundo Bovo, seria um passo significativo para ampliar ainda mais a cultura digital na redação, com a ampla maioria dos profissionais pensando a produção de conteúdo constantemente e uma equipe específica trabalhando para a formatação da edição impressa do dia seguinte.

\subsection{Níveis de adoção}

Após apresentarmos a aplicação dos nossos instrumentos de observação junto a cada um dos aplicativos analisados, cabe-nos fazer alguns apontamentos com relação aos resultados obtidos e também um comparativo entre os dados coletados. Para efeitos de comparação, criamos duas tabelas e dois gráficos com os dados gerais coletados nas análises. A tabela 13 apresenta os comparativos com relação aos dados sobre a adoção das categorias do Jornalismo Ubíquo nos aplicativos das marcas jornalísticas da amostra. Sendo assim, o total de sete categorias representa $100 \%$, onde cada jornal obteve um percentual específico à quantidade de categorias atingidas, para cada uma das possibilidades de implementação, ou seja: Implementada, Parcialmente Implementada e Não Implementada. Essa forma de tabulação dos dados e cálculo das porcentagens indica que demos a todas as categorias o mesmo peso na avaliação, sem atribuir um valor maior ou menor a cada uma delas, de acordo com suas particularidades. Essa opção se deu para que o trabalho pudesse apresentar um resultado mais claro, objetivo e uniforme, mesmo que alguma categoria possa ser mais complexa do que a outra em termos de desenvolvimento e implementação, pois acreditamos que seria arbitrário e subjetivo atribuir diferentes pesos aos aspectos analisados sem uma ampla pesquisa para elencar todos os critérios que os diferenciam e complexificam. 
Tabela 13 - Adoção das categorias do JU nos principais aplicativos das marcas

\begin{tabular}{l|c|c|c|c}
\hline \multirow{2}{*}{ JORNAL } & NYT & GUARDIAN & EL PAÍS & ESTADÃO \\
CATEGORIA & $\boldsymbol{\%}$ & $\boldsymbol{\%}$ & $\boldsymbol{\%}$ & $\boldsymbol{\%}$ \\
\hline Implementada & 14 & 29 & 14 & 0 \\
\hline Parcialmente implementada & 57 & 29 & 14 & 57 \\
\hline Não implementada & 29 & 42 & 72 & 43 \\
\hline Total & 100 & 100 & 100 & 100 \\
\hline
\end{tabular}

Fonte: a autora

Gráfico 13 - Adoção das categorias do JU nos principais aplicativos das marcas

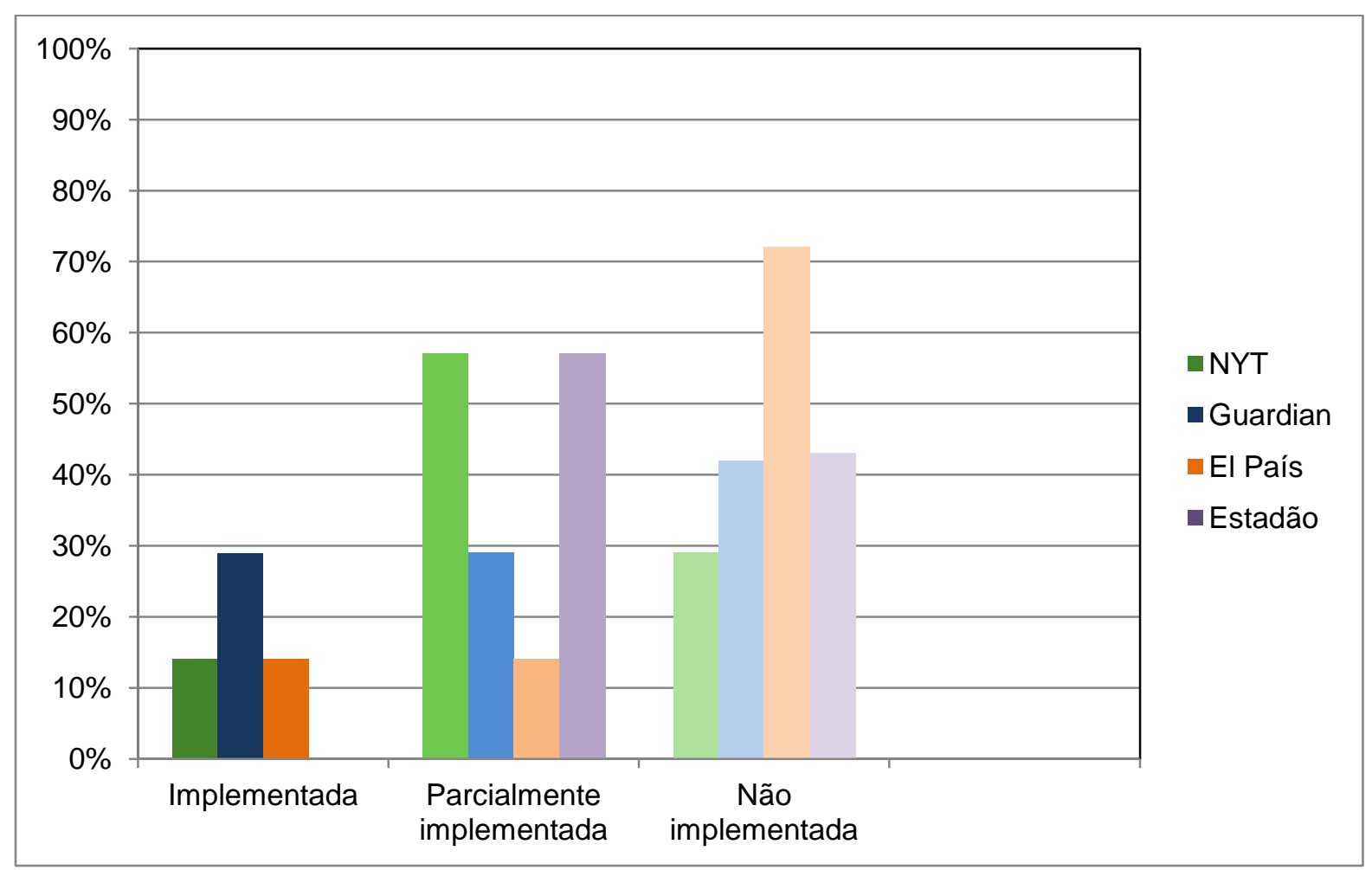

Fonte: a autora

Ao observarmos tanto a tabela quanto o gráfico 13, acima, podemos perceber que, no geral, os aplicativos jornalísticos ainda estão distantes de adotar todas as categorias do Jornalismo Ubíquo e, consequentemente, tirarem proveito das potencialidades oferecidas por essa proposta de jornalismo, pelos dispositivos nos quais ele se distribui e pelos próprios aspectos dos espaços híbridos e dos consumidores da contemporaneidade. Mesmo assim, nossa terceira hipótese de trabalho que diz que os produtos jornalísticos atuais diferem em níveis de apresentação das características do JU, resultando num mercado composto por diferentes soluções de apresentação, umas mais bem adaptadas 
ao momento, outras menos, acaba se confirmando, pois apesar de tomarmos exemplos de marcas jornalísticas consagradas no mercado, elas acabam se diferenciando de forma considerável entre as formas de apresentação das suas características tecnológicas.

O que podemos dizer é que, Guardian e NYT possuem aplicativos com formatos que se aproximam mais das propostas elencadas nas categorias do JU. O primeiro, tem mais categorias implementadas efetivamente e, o segundo, tem mais elementos já em fase de implementação. O aplicativo do El País mostra um caráter mais reticente, com poucas características tanto implementadas e parcialmente implementadas, deixando a maioria ainda num estágio de não aproveitamento no produto atual oferecido pelo jornal. O Estadão foi a única marca jornalística da amostra a não ter efetivamente nenhum aspecto implementado, no entanto, demonstra ter ciência das possibilidades existentes ao apresentar muitas categorias em fase de instalação. Vale ressaltar aqui, no entanto, que todos os jornais possuem características diferentes entre eles, o que certamente influencia nesses resultados. NYT, Guardian e El País são jornais com estratégias internacionais, presenças e redações efetivas em vários países, enquanto o Estadão tem uma atuação focada nacional e muitas vezes, regionalizada em São Paulo. Esse poderio de performance interfere tanto na questão financeira que banca as evoluções físicas, profissionais e tecnológicas quanto na própria necessidade de oferecer um produto mais ou menos desenvolvido ao seu leitor. Cada marca detém o conhecimento sobre o que atende às expectativas do seu público e isso pode levá-la a fazer escolhas que possam retardar a implementação de algum tipo de característica ou até mesmo excluí-la das possibilidades viáveis.

Apesar das particularidades do público que podem atuar como fatores de diferenciação, algumas possíveis "pressões de mercado" também podem fazer parte da equação que define a evolução de um aplicativo de determinada marca. Ao longo da análise, foi possível perceber que nenhum dos aplicativos deixou de implementar a característica da redistribuição. Alguns possuem essa possibilidade mais desenvolvida, outros menos, no entanto nenhum correu o risco de não permitir que seu público compartilhasse seus conteúdos em redes sociais online. Isso ocorre, certamente, porque boa parte da audiência dessas marcas jornalísticas vem desses serviços. Dentre os jornais que fizeram parte de nossa amostra, editores e diretores nos informaram que, em média, 30\% do público vêm de plataformas como Facebook e Twitter. Além disso, de acordo com pesquisa mencionada no item 3.1 deste trabalho, o Reuters Institute Digital 
News Report de 2016 mostra que mais da metade do público consumidor de notícias na internet usa as redes sociais online para se informar. Ou seja, parece-nos que quando a pressão do público e dos serviços externos é grande, os aplicativos e as empresas se forçam a oferecer soluções adequadas e eficazes para sua audiência.

As diferenças de estratégias e também de potencial de financiamento ficam mais claras quando observamos os resultados das avaliações dos designs de navegação e interface dos aplicativos da amostra. A tabela e o gráfico 14 mostram es ses resultados a partir da utilização de porcentagens. O total de categorias, 30, representa 100\%, e cada um dos jornais obteve as parciais correspondentes à quantidade de categorias que demonstrou estar implementada, parcialmente implementada e não implementada. Aqui igualmente optamos por avaliar todos os aspectos de forma uniforme, sem atribuir pesos diferentes a cada um deles, até mesmo porque, a literatura e os autores nos quais nos baseamos para construir o segundo instrumento de observação também não atribuem maior ou menor importância a um ou outro aspecto, mas sim, tratam de suas relevâncias em conjunto para uma melhor apresentação e uso dos produtos digitais.

Tabela 14 - Avaliação dos designs de Navegação e Interface dos principais aplicativos das marcas

\begin{tabular}{|c|c|c|c|c|}
\hline $\begin{array}{ll}\text { CATEGORIA } & \text { JORNAL } \\
\end{array}$ & $\begin{array}{c}\text { NYT } \\
\%\end{array}$ & $\begin{array}{c}\text { GUARDIAN } \\
\%\end{array}$ & $\begin{array}{c}\text { EL PAÍS } \\
\%\end{array}$ & $\begin{array}{c}\text { ESTADÃO } \\
\%\end{array}$ \\
\hline Implementada & 53 & 63 & 50 & 23 \\
\hline Parcialmente implementada & 27 & 17 & 13 & 33 \\
\hline Não implementada & 20 & 20 & 37 & 44 \\
\hline Total & 100 & 100 & 100 & 100 \\
\hline
\end{tabular}

Fonte: a autora 
Gráfico 14 - Avaliação dos designs de Navegação e Interface dos principais aplicativos das marcas

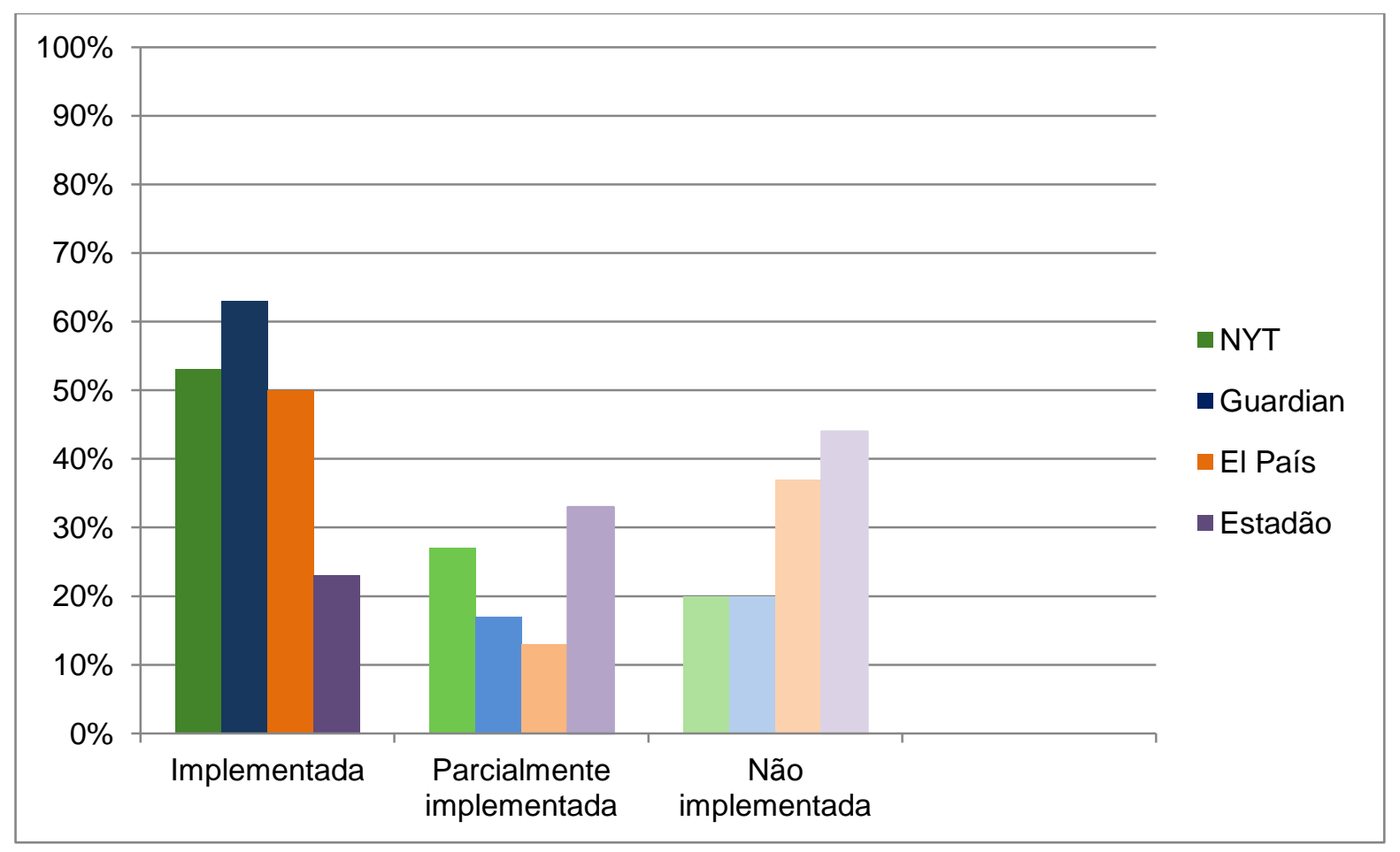

Fonte: a autora

Nesses aspectos de avaliação, fica mais claro o desenvolvimento dos aplicativos do Guardian e do NYT, que demonstram levar mais em consideração heurísticas clássicas e consagradas acerca dos formatos e do desenho de conteúdos para dispositivos móveis digitais. O app do El País, apesar de ficar atrás em muitos dos aspectos que poderiam já estar em implementação, ainda se mostra mais desenvolvido que o do Estadão. O aplicativo da marca jornalística brasileira é visivelmente o produto com mais problemas de estabilidade, coerência e padrão nas interações oferecidas, além de possuir o menor número de categorias efetivamente adotadas.

O que podemos analisar com os dados e resultados expostos aqui é que conseguimos caracterizar um Jornalismo Ubíquo a partir das categorias conhecidas pelas características do contexto contemporâneo em que estamos inseridos e também das potencialidades tecnológicas oferecidas pelos dispositivos móveis digitais, atualmente responsáveis pela maioria dos acessos aos conteúdos jornalísticos disponíveis na rede. Isso, no entanto, não quer dizer que já seja possível visualizar essa categorização nos produtos jornalísticos disponíveis no mercado entre as marcas de mais expressão com o público. O que nos remete à terceira hipótese desta pesquisa, onde pontuamos que os atuais produtos 
jornalísticos para dispositivos móveis digitais diferem nos níveis de adoção e apresentação das categorias do Jornalismo Ubíquo e do seu formato, sendo que alguns estão mais adaptados às propostas contemporâneas e outros menos, resultando num cenário diverso de mercado, com múltiplas e diferentes soluções de adequação às potencialidades da tecnologia e do contexto de produção e consumo.

Esse cenário parece seguir o movimento já tradicional da indústria jornalística desde o surgimento da internet, caracterizado pela lenta adoção de potencialidades e busca incessante pela manutenção do status quo das suas práticas e do seu mercado. No começo do surgimento da internet comercial e, consequentemente, dos principais jornais na $w e b$, o comportamento natural entre jornalistas e empresas era mais de uma presença "burocrática" na rede. Poucos profissionais e empresas davam importância ao que estava acontecendo e aos produtos que nasciam dentro da web. Esse ciclo seguiu com o crescimento da rede acompanhado da bolha.com e da crise de 2008, quando definitivamente os meios passaram a culpar a web pela queda no faturamento e na circulação (SALA VERRÍA, 2016b).

Desde então, o comportamento dentro das empresas jornalísticas têm sido semelhante: muitos cortes de funcionários, cortes de cadernos, redução do número de edições etc. Ao mesmo tempo, abrem-se alguns espaços para investimentos nas publicações digitais e produções voltadas exclusivamente para a rede. A crise, contudo, permanece diante da falta de um modelo de negócios adequado para o novo contexto contemporâneo. Esse modelo de negócios não se resume a novo um modelo de receita ou de canais de faturamento, mas inclui também uma compreensão do funcionamento dos processos de consumo de conteúdo na atualidade, uma mudança cultural na forma de compreender as novas dinâmicas de consumo, compartilhamento e produção de conteúdo e, ainda, um olhar atento ao potencial oferecido pela evolução tecnológica e sua interferência direta nos espaços de vivência e no comportamento dos sujeitos actantes. 


\section{CONSIDERAÇÕES FINAIS}

Este trabalho foi motivado por um interesse em buscar formas de apresentação e construção do jornalismo para os dispositivos que demonstram ser os principais atores no processo de consumo de conteúdo nos anos atuais e também nos que se seguem. Em nossa atuação como pesquisadores do campo da Comunicação e dos Estudos em Jornalismo, temos essa inquietação como elemento motivador do nosso trabalho: como podemos adaptar a produção, a apresentação e a distribuição do jornalismo para um modelo que seja atrativo aos novos consumidores e tire proveito das potencialidades oferecidas pela evolução tecnológica, respeitando as características éticas e fundamentais da profissão? Obviamente não tínhamos a pretensão de responder esta pergunta por completo neste trabalho, no entanto, nos empenhamos aqui num esforço que pudesse contribuir e acrescentar elementos à jornada coletiva de traçar os caminhos futuros do jornalismo.

Nosso trabalho começou com a apresentação desta pesquisa, seus objetivos, hipóteses e problemática. A partir daí, entregamos ao leitor uma visão abrangente do lugar de fala que assumimos nesta pesquisa. Nosso marco teórico-metodológico adotou autores que nos forneceram uma visão diferente da tradicional com relação ao social e ao campo da Comunicação. Ao utilizarmos as propostas da Teoria Ator-Rede, materialidade da comunicação, Teoria dos Sistemas e metáfora da espuma como lente através da qual olhamos nosso objeto de pesquisa, estamos nos posicionando num local específico da atuação, enquanto pesquisadores, onde deixamos de lado qualquer determinismo social e técnico, para optar por uma visão que dá importância a todos os atores do processo comunicacional, humanos e não humanos e considera suas agências e papéis dentro das interações.

Em seguida, explicitamos o caminho teórico que percorremos até a chegada ao conceito de Jornalismo Ubíquo que nos é tão caro e importante para o trabalho. É este conceito que nos permite entender que o jornalismo evolui também em seu construto teórico, não elaborando novos fundamentos para a profissão, mas compreendendo que seus formatos de produção, distribuição e consumo se alteram profundamente na contemporaneidade e demandam um olhar que dê conta de todas as possibilidades que se abrem para a entrega de um produto mais rico e personalizado ao consumidor. Tratamos aqui da possibilidade de oferta de um resultado narrativo ainda mais relevante e 
significante para o usuário, capaz de demonstrar seu valor não apenas na relevância para manutenção de uma coletividade justa e democrática, mas também nos aspectos mais particulares da vida do consumidor e nas suas necessidades mais específicas.

A fim de tornar mais visíveis e palpáveis essas possibilidades das quais falamos, abrimos o conceito do JU em categorias e elementos internos a ele. A partir disso, e do conceito de narrativa sistêmica, expomos também características do formato de apresentação dos produtos deste JU, ponto específico do qual buscamos dar conta neste trabalho dentro da infinidade de aspectos que fazem parte do processo evolutivo do jornalismo contemporâneo. Com esse conjunto de propriedades em mãos, nos debruçamos sobre conceitos relacionados ao design de navegação e interface, experiência do usuário e usabilidade, para elaborar instrumentos de observação que pudessem nos auxiliar na tarefa de enxergar o jornalismo ubíquo em nossos objetos empíricos.

De posse de nossos dois instrumentos de observação, fomos aos aplicativos para smartphone dos jornais The New York Times, The Guardian, El País e O Estado de S. Paulo, a fim de investigar, e até mesmo procurar, a concretização dos elementos que categorizamos no trabalho. Com esse percurso, cremos ter conseguido completar todos os objetivos aos quais nos propusemos alcançar no início da pesquisa e as hipóteses que foram formuladas quando ainda nos debruçávamos sobre a construção de um trabalho, a partir das perguntas que explicitamos no início dessas considerações. Foi possível expor, a partir de nossa pesquisa bibliográfica e também dos dados que trouxemos ao trabalho, que estamos efetivamente vivendo um momento em que o jornalismo é profundamente afetado pelo desenvolvimento tecnológico da mobilidade digital e da ubiquidade, movendo-nos em direção a uma proposta conceitual que dê conta corretamente desse cenário: o jornalismo ubíquo. Também foi possível organizar e apresentar as características desse jornalismo e do formato que dele surge, com uma série de elementos próprios à evolução da produção e também aos dispositivos móveis digitais, como geolocalização, contextualidade, navegação em camadas, automação e integração ao sistema. Por último, nossa terceira hipótese aparece quando nossa investigação mostrou que, até o momento, não temos nenhum app dando conta de todas as potencialidades existentes e possíveis de serem implementadas com funcionalidades ao público. Temos um cenário com diferentes níveis de adoção e uma multiplicidade de 
soluções apresentadas pela amostra, mesmo sendo ela composta por marcas jornalísticas de forte expressão no mercado.

A partir do nosso trabalho desenvolvido até aqui e também de nossas pesquisas paralelas que se aprofundam no tema do jornalismo ubíquo, bem como suas características até então visíveis no mercado, podemos dizer que, atualmente, não existem modelos de formatos jornalísticos exclusivos para dispositivos ubíquos, mas sim, propostas de estruturas narrativas e de negócio para a produção de um jornalismo que perpassa múltiplos dispositivos. Ou seja, o mais comum de se encontrar é que o conteúdo visível em aplicativos jornalísticos para smartphones é exatamente o mesmo presente nos websites dos veículos, muitas vezes este é até igual ao que é distribuído nas versões impressas de jornais.

Não foi nosso objetivo, aqui, validar se essa postura é certa ou errada, o que sabemos e pudemos expressar em nossa pesquisa é que ela acarreta um forte subaproveitamento de todas as possibilidades de entrega de um conteúdo mais rico e valoroso ao usuário. O que estamos buscando é a descrição e a compreensão de um momento vivido pela indústria e pelos consumidores. Além disso, o que se percebe é que nossos objetos de observação neste trabalho demonstram que estão realizando uma busca por formatos mais adaptados às potencialidades dos dispositivos ubíquos, a partir da implementação de aspectos como personalização, leitura em camadas, redistribuição de conteúdo e notificações por push. Esta busca, no entanto, ainda se dá numa velocidade lenta em comparação a outros produtos característicos da era digital como redes sociais online, por exemplo.

Portanto, o caminho ainda é trilhado com um comportamento defensivo e cauteloso. Há pouquíssima experimentação com geolocalização, com uso de algoritmos, com realidade aumentada, com conexão entre dispositivos baseados em internet das coisas e até mesmo wearables. Além disso, os formatos da narrativa não variam. A apresentação do texto é a mesma que vemos no desktop e que, por sua vez, deriva de um modelo de diagramação vindo do jornal impresso. O que se pode dizer até aqui é que o caminho para a constituição de formatos e modelos apropriados para o jornalismo ubíquo ainda demanda muita experimentação e ousadia por parte das empresas e, claro, empatia por parte dos consumidores de conteúdo.

A inovação e a disrupção podem ser saídas para o jornalismo. Um questionamento que fica ao final da realização deste trabalho é se encontraríamos o 
mesmo cenário de implementação caso tivéssemos optado por pesquisar empresas "digital born", ou seja, já nascidas dentro da lógica da internet e das redes sociais online. Não sabemos qual cenário encontraríamos nem até que ponto ele se demonstraria sustentável no futuro e se o público teria por ele a mesma relação de credibilidade existente com as marcas jornalísticas tradicionais. No entanto, o uso e o consumo de produtos de empresas com essa característica nos dá uma suspeita de que ainda não encontraríamos todas as possibilidades realizáveis apresentadas e apropriadas pelo jornalismo.

O que sabemos é que dentro das propostas de disrupção não cremos que estamos vendo um processo profundamente concluído no âmbito do jornalismo. Há empresas inovadoras, oferecendo produtos diferentes e mais baratos, mas ainda não temos uma migração profunda do público para esses veículos. Talvez o movimento disruptivo do jornalismo tenha mais um caráter de cauda longa, podendo significar que, nos próximos anos, o público se disperse entre diversas publicações de nicho que oferecem diferentes tipos de conteúdo e em múltiplas medidas de qualidade. O que o comportamento do público jovem atual parece nos mostrar é que eles não estão interessados em fidelidade completa a uma marca jornalística. Antes disso, querem que o conteúdo chegue a eles de forma descomplicada, personalizada e contextualizada, sem demandar esforço de suas partes. No entanto, essa é uma observação puramente leiga e inicial, o que nos reforça a necessidade de continuidade da pesquisa a partir da investigação dos mercados nascidos digitais e também do público nascido digital.

Além disso, também cabe seguir a pesquisa com a problematização sobre o tipo de conteúdo que o público deseja que seja entregue a ele nos dispositivos móveis digitais. Nossa pesquisa focou-se em investigar os formatos nos quais esse conteúdo pode ser apresentado e distribuído, mas cabe para o futuro tentar compreender em qual tipo de conteúdo os usuários estão interessados ao longo dos seus micromomentos diários e de seus contextos de localização. A afirmação feita por membros de nossa amostra de pesquisa de que o público deseja ter no celular a experiência completa e clássica de um jornal tradicional ainda carece de validação, pois os públicos futuros poderão ter comportamentos ainda mais diferentes de consumo do que aqueles que já vemos hoje. Sendo assim, a partir de todo o conteúdo exposto neste trabalho, das categorias trabalhadas, dos conceitos esmiuçados e da coleta de dados problematizada, esperamos que seja possível construir uma noção mais completa do que pode ser uma 
configuração mais satisfatória do desenho de formatos narrativos e, com isso, procurar, em estudos futuros, aplicar essas possibilidades aos produtos desenvolvidos por marcas jornalísticas brasileiras, internacionais e também nativas digitais. 


\section{REFERÊECIAS ${ }^{92}$}

AGAMBEN, G. O que é um dispositivo?. In: O que é o contemporâneo e outros ensaios. Chapecó: Argos, 2009.

AGUADO, J. M. La indústria del contenido em la era Post-PC: horizontes, amenazas y oportunidades. In: CANAVILHAS, J. (org). Notícias e mobilidade: jornalismo na era dos dispositivos móveis. Universidade da Beira do Interior, Covilhã, Portugal: Labcom, 2013.

.; CASTELlet, A. Periodismo móvil e información ubicua. In: AGUADO, J. M.; FEIJÓO, C.; MARTÍNEZ, I. J. (org.). La comunicación móvil: hacia un nuevo ecosistema digital. Barcelona: Cediza, 2013.

.; FEIJÓO, C.; MARTÍNEZ, I. J. (org.). La comunicación móvil: hacia un nuevo ecosistema digital. Barcelona: Cediza, 2013.

.; MARTINÉZ, I. J. La cuarta pantalla: industrias culturales y contenido móvil. In: AGUADO, J. M.; MARTINÉZ, I. J. Sociedad móvil: tecnología, identidad y cultura. Madrid: Biblioteca Nueva, 2008b.

Nueva, 2008.

Sociedad móvil: tecnología, identidad y cultura. Madrid: Biblioteca

ALVES, R. C. Prólogo: Veinte años después, el ciberperiodismo aún parece un adolescente. In: SALAVERRÍA, R. Ciberperiodismo en Iberoamérica. Espanha: Fundación Telefónica e Editorial Ariel, 2016b.

ANDERSON, C. W.; BELL, E.; SHIRKY, C. Post-industrial journalism - adapting to the present, tow center for digital journalism. Columbia Journalism School, 2013. Disponível em: <http://towcenter.org/research/post-industrial-journalism>. Acesso em: 25 de set. de 2013.

$\overline{2015}$.

.; MAEYER, J. de. Objects of journalism and the news. Journalism, v. 16, n. I,

ARAUJO, R. B. de. Computação ubíqua: princípios, tecnologias e desafios. In: XXI SIMPÓSIO BRASILEIRO DE REDES DE COMPUTADORES, Natal, RN, p. 45-115, SBRC2003.

BAIRON, S. Às margens da compreensão com o digital. Caxias do Sul, RS, Antares, v. 7, n. 14, 2015.

BARBOSA, A. F. (coord.). Pesquisa sobre o uso das tecnologias da informação e comunicação nos domicílios brasileiros: TIC domicílios 2015. São Paulo: Comitê Gestor da Internet no Brasil. Disponível em: <http://cetic.br/pesquisa/domicilios/>. Acesso em: 11 jul. 2016.

\footnotetext{
${ }^{92}$ De acordo com a Associação Brasileira de Normas Técnicas. NBR 6023.
} 
BARBOSA, S. Jornalismo convergente e continuum multimídia na quinta geração do jornalismo nas redes digitais. In: CANAVILHAS, J. (org.). Notícias e mobilidade: jornalismo na era dos dispositivos móveis. Portugal: Labcom, 2013.

. Modelo JDBD e o ciberjornalismo de quarta geração. In: FLORES VIVAR, J. M.; RAMÍREZ, F. E. (eds.). Periodismo Web 2.0. Madrid: Fragua, 2009.

. SEIXAS, L. Jornalismo e dispositivos móveis: percepções usos e tendências. In: BARBOSA, S.; MIELNICZUK, L. Jornalismo e tecnologias móveis. Portugal: LabCom, 2013.

Sistematizando conceitos e características sobre o jornalismo digital em base de dados. In: BARBOSA, S. (org.). Jornalismo digital de terceira geração. Portugal: Labcom, 2007.

.; SILVA, F. F. da; NOGUEIRA, L.; ALMEIDA, Y. Journalistic activity on mobile platforms: a study on autochthonous products and changes to the journalist's professional profile. Brazilian Journalism Research, v. 9, n. 2, 2013.

; TORRES, V. O paradigma 'Jornalismo Digital em Base de Dados': modos de narrar, formatos e visualização para conteúdos. Revista Galaxia, São Paulo, n. 25, 2013.

BERGHELLA, V. Redes sociales y audiencias: claves para la distribución social de las noticias. In: ROITBERG, G.; PICCATO, F. Periodismo disruptivo: dilemas y estrategias para la innovación. Buenos Aires: La Crujía, 2015.

BERTOCCHI, D. Dos dados aos formatos: um modelo teórico para o design do sistema narrativo no jornalismo digital. 2014. 250 p. Tese (Doutorado em Ciências da Comunicação) - Escola de Comunicações e Artes da Universidade de São Paulo. São Paulo, 2014.

Dos dados aos formatos: a construção de narrativas no jornalismo digital. Curitiba: Appris, 2016.

BLOOMFIELD, B. P. et al. Bodies, Technologies and Action Possibilities: When is an Affordance?. Sociology, v. 44, n. 3, 2010.

BOLTER, J. D.; GRUSIN, R. Remediation: understanding new media. MIT, 2000.

BRADSHAW, P. A model for the 21st century newsroom. 2007. Disponível em: <http://onlinejournalismblog.com/2007/09/17/a-model-for-the-21st-century-newsroompt1-the-news- diamond/ > Acesso em: 13 set de 2013.

BURGOS, T. de L. Design de sites web mobiles e de softwares aplicativos para jornalismo digital em base de dados. In: CANAVILHAS, J. (org.). Notícias e mobilidade: jornalismo na era dos dispositivos móveis. Universidade da Beira do Interior, Covilhã, Portugal: Labcom, 2013. 
CAMARGO, I. O. de. Caracterização, processos de produção e tendências do jornalismo em mobilidade: um estudo de caso do The New York Times. 2015. Dissertação (Mestrado em Teoria e Pesquisa em Comunicação) - Escola de Comunicações e Artes, Universidade de São Paulo, São Paulo, 2015.

CAMARGO, L. S. de A. de; VIDOTTI, S. A. B. G. Arquitetura de informação para ambientes informacionais digitais: integração de serviços de personalização e customização. São Paulo, Ibersid, p. 227-231, 2009.

CANAVILHAS, J. Da pirâmide invertida à pirâmide deitada. 2005. Disponível em: 〈http:qqbocc.unisinos.br/pag/canavilhas-joao-webjornalismo-piramide-invertida.pdf $>$.

Acesso em: 18 ago. 2012.

Do jornalismo online ao webjornalismo: formação para mudança. In: Comunicação e Sociedade, v. 9-10, p.113-119, 2006. Disponível em: <http://www.lasics.uminho.pt/OJS/index.php/comsoc/article/view/1159/1102>. Acesso em: 18 ago. 2012.

Hipertextualidade: Novas arquiteturas noticiosas. In: Webjornalismo: 7 características que marcam a diferença. Portugal: LABCOM, 2014.

CASTELLET, A.; FEIJÓO, C. Los actores en el ecosistema móvil. In: AGUADO, J. M.; FEIJÓO, C.; MARTÍNEZ, I. J. (org.). La comunicación móvil: hacia un nuevo ecosistema digital. Barcelona: Cediza, 2013.

CASTELLS, M. La galaxia Internet. Barcelona, Espanha: Arete, 2001.

CHANG, K.; KING, S. Understanding industrial design. EUA: O'Reilly, 2015.

CHAPLIN, H. Guide to Journalism and Design. EUA: Tow Center, 2016. Disponível em: 〈http://towcenter.org/a-guide-to-journalism-and-design/>. Acesso em: 13 set. 2016.

CHARTIER, R. Os desafios da escrita. São Paulo: UNESP, 2002.

CORRÊA, E. S. Centralidade, transversalidade e resiliência: reflexões sobre as três condições da contemporaneidade digital e a epistemologia da Comunicação. In: XIV CONGRESSO INTERNACIONAL IBERCOM, trabalho apresentado na Divisão Temática Epistemologia, Teoria e Metodologia da Comunicação. Universidade de São Paulo, 2015.

CORRÊA, E. S.; BERTOCCHI, D. A cena cibercultural do jornalismo contemporâneo: web semântica, algoritmos, aplicativos e curadoria. Revista Matrizes, ECA/USP, v. 5, n. 2012. Disponível em: <http://www.matrizes.usp.br/index.php/matrizes/article/view/340> Acesso em: 1 jan. 2013.

DELOITTE. Mobile Consumer 2015: The UK Cut. Londres: Deloitte LLP, 2015a.

Mobile Consumer Survey: principales conclusiones en España. Londres: Deloitte LLP, 2015b. 
DIMMICK, J.; FEASTER, J. C.; HOPLAMAZIAN, G. J. News in the Interstices: The Niches of Mobile Media in Space and Time. New Media \& Society, v. 13, n. 1, 2011.

DITRENDIA. Mobile en España y en el Mundo 2015. Madrid: Tatum, 2015.

FARMAN, J. Mobile Interface Theory: embodied space and locative media. EUA: Routledge, 2012.

FELICE, M. Di. Do social para as redes. In: LEMOS, A. A comunicação das coisas: teoria ator-rede e cibercultura. São Paulo: Anablume, 2013.

FELINTO, E. Passeando no labirinto: ensaios sobre as tecnologias e as materialidades da comunicação. Porto Alegre: PUCRS, 2006.

'Materialidades da Comunicação': por um novo lugar da matéria na Teoria da Comunicação. Ciberlegenda, Rio de Janeiro, n. 5, 2001.

FIRMINO, F. Jornalismo móvel. Salvador: UFBA, 2015.

FUNARO, V. M. B. O. (Coord.) et al. Diretrizes para apresentação de dissertações e teses da USP: parte I (ABNT)/Sistema Integrado de Bibliotecas da USP. 3. ed. rev. ampl. mod. São Paulo: SIBiUSP, 2016. 100p. (Cadernos de estudos; 9).

GARRETT, J. J. The elements of user experience: user-centered design for the web and beyond. Berkeley: New Riders, 2011.

GIBSON, J. J. The ecological approach to visual perception. London: LEA, 1986.

GIBSON, W. Neuromancer. New York: Ace, 1984.

GREENO, J. G. Gibson’s Affordances. Psychological Review, v. 101, n. 2, 1994.

GRIFFITHS, S. Os princípios de UX para aplicativos em dispositivos móveis. Google, $2015 . \quad$ Disponível em: <http://storage.googleapis.com/think/intl/ALL_br/docs/mobile-app-uxprinciples_articles.pdf> Acesso em: 19 maio 2015.

GRUSZYNSKI, A. Design de jornais multiplataforma: delineando níveis de avaliação a partir do estudo de Zero Hora (ZH). In: PALACIOS, M.; MARTINS, E. Ferramentas para análise de qualidade no ciberjornalismo. Volume 2: Aplicações. Portugal: Labcom, 2016.

GUMBRECHT, H. U. O campo não hermenêutico ou a materialidade da comunicação. Teresa Revista de Literatura Brasileira, São Paulo, n. 10/11, p. 386-407, 2010.

HANKE, M. M. Materialidade da comunicação: um conceito para a ciência da comunicação? Interin, v.1, p.1-8, 2006.

Materialidade da Comunicação - um conceito para a Ciência da Comunicação?. Contracampo, Rio de Janeiro, n. 14, 2006. 
HARTSON, R.; PYLA, P. The UX Book: process and guidelines for ensuring a quality user experience. EUA: Elsevier, 2012.

HAUGEN, K. R. H. Mobile news: design, user experience and recommendation. Dissertação (Mestrado em Ciência da Computação) - Universidade de Ciência e Tecnologia da Noruega, 2013. Disponível em: <http://www.divaportal.org/smash/record.jsf?pid=diva2\%3A655616\&dswid=-9398>. Acesso em: 08 set. de 2014.

HOLANDA, A. F. da C. Traduzindo o jornalismo para Tablets com a Teoria AtorRede. Tese (Doutorado em Comunicação e Cultura Contemporâneas) - Programa de Pós-Graduação em Comunicação e Cultura Contemporâneas - Faculdade de Comunicação da Universidade Federal da Bahia. Salvador, 2014.

IPSOS CONNECT. Tech Tracker Q1 2016. Londres: Ipsos Connect, 2016.

IRIARTE, M. J. Móvil primero. In: ROITBERG, G.; PICCATO, F. Periodismo disruptivo: dilemas y estrategias para la innovación. Buenos Aires: La Crujía, 2015.

JARVIS, J. Geeks bearing gifts: imagining new futures for news. Disponível em: <https://medium.com/geeks-bearing-gifts>. Acesso em: 15 abr. 2015.

JENKINS, H. Convergence culture: where old and new media collide. New York: New York University, 2006.

.; FORD, S.; GREEN, J. Spreadable media: creating value and meaning in a networked culture. New York: NYU Press, 2013.

JENSEN, K. B. What's mobile in mobile communication? Mobile Media \& Communication, v.1, Sage Publications, 2013.

JOHNSON, S. Cultura da interface: como o computador transforma nossa maneira de criar e comunicar. Rio de Janeiro: Zahar, 2001.

KATZ, J. E. Cuestiones teóricas en torno a medios móviles y comunicación. In: AGUADO, J. M.; MARTINÉZ, I. J. Sociedad móvil: tecnología, identidad y cultura. Madrid: Biblioteca Nueva, 2008.

KISNER, C.; SISCOUTTO, R. (Org). Realidade virtual e aumentada: conceitos, projeto e aplicações. Porto Alegre: SBC - Sociedade Brasileira de Computação, 2007.

LATOUR, B. Reassembling the social: an introduction to Actor-Network Theory. Oxford: Oxford University Press, 2005.

$\overline{34}, 1994$.

Jamais fomos modernos: ensaio de antropologia simétrica. Rio de Janeiro:

On technical mediation. Common Knowledge, Inglaterra, v. 3, n. 2, 1994b. 
. Reagregando o social: uma introdução à teoria do ator-rede. Salvador (BA), Bauru (SP): UFBA, USC, 2012.

LEBER, J. Questions for Mobile Computing. 2012. MIT Technology Review. Disponível em: <https://www.technologyreview.com/s/427784/questions-for-mobilecomputing/>. Acesso em: 08 set. 2014.

LEMOS, A. Tecnologia e cibercultura. In: CITELLI, A.; BERGER, C.; BACCEGA, M. A.; LOPES, M. I. V.; FRANÇA, V. V. (Orgs.). Dicionário de Comunicação: escolas, teorias e autores. São Paulo: Contexto, 2014.

Nupef, n. 9, 2011.

Things (and People) are the Tools of the Revolution. In: poliTICs, Instituto

Comunicação e práticas sociais no espaço urbano: as características dos Dispositivos Híbridos Móveis de Conexão Multirredes (DHMCM). Revista Comunicação, mídia e consumo, São Paulo, v. 4, n. 10, p. 23-40, jul-2007.

A comunicação das coisas: teoria ator-rede e cibercultura. São Paulo: Anablume, 2013.

Cidade e mobilidade: telefones celulares, funções pós-massivas e territórios informacionais. Matrizes, n. 1, 2007.

. Cultura da mobilidade. Revista Famecos. Porto Alegre, n. 40, quadrimestral, dez. 2009.

24,2012 .

Dispositivos de leitura eletrônicos. Comunicação, Mídia e Consumo, v. 9, n.

LÉVY, P. Cibercultura. São Paulo: 34, 1999.

LIEBER, R. Teoria de sistemas. (Material didático). Departamento de Produção da Faculdade de Engenharia da UNESP. 2001. Disponível em: <http://www.ebah.com.br/content/ABAAAAJD8AJ/teoria-sistemas $>$. Acesso em: 08 set. 2014.

LIEVROUW, L. A. Materiality and media in communication and technology studies. In: GILlESPIE, T.; BOCZKOWSKI, P. J.; FOOT, K. A. (orgs.). Media technologies: essays on communication, materiality, and society. London: MIT Press, 2014.

LIMA, E. P. Teoria dos Sistemas. In: CITELLI, A.; BERGER, C.; BACCEGA, M. A.; LOPES, M. I. V.; FRANÇA, V. V. (orgs.). Dicionário de Comunicação: escolas, teorias e autores. São Paulo: Contexto, 2014.

LOPES, M. I. V. de. Pesquisa em comunicação. 6. ed. São Paulo: Loyola, 2001.

LUHMANN, N. Introducción a la teoría de sistemas. Mexico: Universidad Iberoamericana, 1996. 
Anthropos, 1998.

Sistemas sociales: lineamientos para una teoría general. Barcelona:

MACHADO, I. Gêneros e/ou formatos? Design de linguagem mediada. Congresso Brasileiro de Ciências da Comunicação, Santos, SP, 2007.

MANOVICH, L. The language of new media. Cambridge: MIT Press, 2001.

Software takes command. Bloomsbury Academic, 2013.

MCLUHAN, M. Os meios de comunicação como extensões do homem. São Paulo: Cultrix, 1969.

MIELNICZUK, L. Jornalismo na Web: uma contribuição para o estudo do formato da notícia na escrita hipertextual. 2003. Tese (Doutorado em Comunicação e Culturas Contemporâneas). - Faculdade de Comunicação da Universidade Federal da Bahia. Salvador, 2003.

Características e implicações do jornalismo na web. In: II CONGRESSO DA SOPCOM, Lisboa, 2001.

MILLER, D; SLATER, D. The Internet: an ethnographic approach. Oxford: Berg, 2000 .

MORVILLE, P.; ROSENFELD, L. Information architecture for the world wide web. CA: O'Reilly Media, 2007.

NEVES, C. E. B.; NEVES, F. M. O que há de complexo no mundo complexo? Niklas Luhmann e a Teoria dos Sistemas Sociais. Sociologias, Porto Alegre, ano 8, n. 15, p. 182-207, jan/jun 2006.

NEWMAN, N.; FLETCHER, R.; LEVY, DAVID A. L.; NIELSEN, R. K. Reuters Institute Digital News Report 2016. Londres: Reuters Institute for the Study of Journalism, 2016.

NIELSEN, J. 10 usability heuristics for user interface design. 1995. Disponível em: <https://www.nngroup.com/articles/ten-usability-heuristics/> Acesso em: 10 ago 2015.

NORMAN, D.; NIELSEN, J. Gestural interfaces: a step backward in usability. Interactions, v. 17, issue 5, sept-oct. 2010. Disponível em <http://www.jnd.org/dn.mss/gestural_interfaces_a_step_backwards_in_usability_6.html $>$ Acesso em: 7 out. 2015.

OKAZAKI, S.; MENDEZ, F. Perceived ubiquity in mobile services. Journal of Interactive Marketing, v. 27, p. 98-111, 2013.

OliVEIRA, H. P. C. de; VIDOTTI, S. A. B. G.; BENTES, V. Arquitetura da informação pervasiva. São Paulo: UNESP, 2015. 
OLIVEIRA, V. R. de. Interfaces jornalísticas em tablets: o design digital da informação nos aplicativos móveis. Dissertação (Mestrado) - Programa de PósGraduação em Jornalismo, Universidade Federal de Santa Catarina. Florianópolis, 2013.

PALACIOS, M.; BARBOSA, S.; FIRMINO, F.; CUNHA, R. Aplicativos jornalísticos vespertinos para tablets: cartografia do fenômeno ante o desafio de uma produção original e inovadora. Sur le journalisme, About journalism, Sobre jornalismo, v. 3, n. $2,2014$.

; CUNHA, R. do E. S. A tactilidade em dispositivos móveis: primeiras reflexões e ensaios de tipologias. Contemporânea, Comunicação e Cultura, Bahia, v. 10, n. 03, 2012.

PALOMO, B.; QUADROS, I.; SILVA, F. F. Ferramenta para Análise de design em cibermeios. In: PALÁCIOS, M. Ferramentas para Análise de Qualidade no Ciberjornalismo. Volume 1: Modelos. Portugal: LABCOM, 2011.

PANG, A. S.-K. The end of cyberspace and the emerging telecommunications convergence. Towards a Philosophy of Telecommunications Convergence Conference, Budapeste, Hungria, 2007.

PAUL, N. "New news" retrospective: is online news reaching its potential? Online Journalism Review. 2005.2 Disponível em: <http://www.ojr.org/ojr/stories/050324paul>. Acesso em: 02 mar. 2012.

PAVLIK, J. Ubiquidade: $\mathrm{O} 7^{\circ}$ princípio do jornalismo na era digital. In: CANAVILHAS, J. Webjornalismo: 7 características que marcam a diferença. Portugal: LabCom, 2014.

PELLANDA, E. C. Mobilidade e personalização como agentes centrais no acesso individual das mídias digitais. Revista E-Compós - Revista da Associação Nacional de Programas de Pós-Graduação em Comunicação, v. 9, p. 1-14, ago 2007.

Comunicação móvel no contexto brasileiro. In: LEMOS, A.; JOSGRILBERG, F. (Org). Comunicação e mobilidade: aspectos socioculturais das tecnologias móveis de comunicação no Brasil. Salvador: UFBA, 2009.

Consolidação e disrupção do jornalismo móvel em 2017. 2016. Disponível em: $\quad<$ https://jornalismonobrasilem2017.com/consolida\%C3\%A7\%C3\%A3o-edisrup\%C3\%A7\%C3\%A3o-do-jornalismo-m\%C3\%B3vel-em-2017d24fd2782094\#.kcohpom0j> Acesso em: 10 jan. 2017.

PELLEGRINO, G. Ubiquity and Pervasively: on the technological mediation of (mobile) everyday life. In: IFIP International Federation for Information Processing. Social Informatics: An Infonnation Society for All? Boston, Springer, v. 223, 2006.

PEREIRA, V. A. Estendendo McLuhan: da aldeia à teia global. Porto Alegre: Sulina, 2011. 
PICCATO, F. Diseñar la disrupción. In: ROITBERG, G.; PICCATO, F. Periodismo disruptivo: dilemas y estrategias para la innovación. Buenos Aires: La Crujía, 2015.

PIRES, J. de A. Leitura e virtualidade: tecendo entre as linhas da narrativa. In: COELHO, L. A. L.; FARBIARZ, A. Design: olhares sobre o livro. Teresópolis, RJ: Novas Ideias, 2010.

PURCELL, K. et al. Understanding the participatory news consumer: How Internet and cell phone users have turned news into a social experience, Pew Internet \& American Life Project, 2010.

RAMOS, D. O. Formato, condição para a escrita do jornalismo digital de bases de dados: uma contribuição da semiótica da cultura. 2011. 146p. Tese (Doutorado em Ciências da Comunicação) - Escola de Comunicações e Artes, Universidade de São Paulo. São Paulo, 2011.

REIG, R. Crisis del sistema, crisis del periodismo. Barcelona: Gedisa, 2015.

RESMINI, A.; ROSATI, L. Pervasive information architecture: designing cross channel user experiences. [Kindle Edition] Elsevier/Morgan Kaufmann, 2011.

ROWLAND, C.; GOODMAN, E.; CHARLIER, M.; LUI, A.; LIGHT, A. Designing Connected Products. EUA: O'Reilly, 2017.

SAAD, B. Estratégias 2.0 para a mídia digital: internet, informação e comunicação. São Paulo: Senac, 2003.

SAFFER, D. Designing gestural interfaces. O'Reilly, Sebastopol, 2009.

SALAVERRÍA, R.; AVILÉS, J. A. G. La convergencia tecnológica en los medios de comunicación: retos para el periodismo. Trípodos, Barcelona, n. 23, p. 31-47, 2008.

- Los medios de comunicación que vienen. In: SÁDABA, C.; GARCÍA AVILÉS, J. A.; MARTÍNEZ-COSTA, M. P. (Coords.) Innovación y desarrollo de los cibermedios en España, pp. 255-263. Pamplona: EUNSA, 2016a.

Ciberperiodismo en Iberoamérica. Espanha: Fundación Telefónica e Editorial Ariel, 2016b.

Jornalismo ubíquo: a informação jornalística na Internet das coisas. Palestra proferida no III Congresso de Jornalismo para Dispositivos Móveis, Covilhã, Portugal, Universidade da Beira Interior, 2016c.

- Multimedialidade: Informar para cinco sentidos. In: CANAVILHAS, J. Webjornalismo: 7 características que marcam a diferença. Portugal: LabCom, 2014.

Redacción periodística en internet. Pamplona: EUNSA, 2005.

Siete periodismos con futuro. In: PICCATO, F.; ROITBERG, G. Periodismo disruptivo: dilemas y estrategias para la innovación. Buenos Aires: La Crujía, 2015. 
SANTAELlA, L. Comunicação e pesquisa: projetos para mestrado e doutorado. São Paulo: Hacker, 2001.

A ecologia pluralista da comunicação: conectividade, mobilidade,

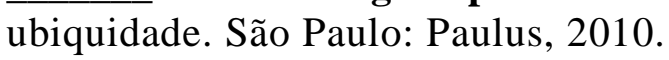

Linguagens líquidas na era da mobilidade. São Paulo: Paulus, 2007.

.; CARDOSO, T. O desconcertante conceito de mediação técnica em Bruno Latour. Matrizes, São Paulo, v. 9, n. 1, 2015.

SANTOS, B. de S. Introdução a uma ciência pós-moderna. Rio de Janeiro: Graal, 1989.

SANTOS, M. A natureza do espaço: técnica e tempo, razão e emoção. São Paulo: Universidade de São Paulo, 2006.

SANTOS, M. C. Jornalismo, mobilidade e realidade aumentada: notas sobre possibilidades de utilização. In: CANAVILHAS, J.; SATUF, I. Jornalismo para dispositivos móveis. Portugal: LabCom, 2015.

SCOLARI, C. A.; GÜERE, H. N.; GARCÍA, I. et al. The Barcelona mobile cluster: actors, contents and trends. iJIM, v. 3, n. 3, 2009. Disponível em: <http://onlinejournals.org/i-jim/article/view/814/951>. Acesso em: 20 set. 2012.

SHAPPIRO, A. L. The disappearance of cyberspace and the rise of code. In: SYMPOSIUM: CONSTITUTIONAL ISSUES INVOLVING USE OF THE INTERNET, 1998. Disponível em: <https://cyber.harvard.edu/is99/Shapiro.htm>. Acesso em: ago. 2016.

SHITKOVA, M.; HOLLER, J.; HEIDE, T.; CLEVER, N.; BECKER, J. Towards usability guidelines for mobile websites and applications. $12^{\circ}$ INTERNATIONALEN TAGUNG WIRTSCHAFTSINFORMATIK, Proceedings... Osnabrück, Alemanha, 2015, p. 1603-1617.

SILVA, F. F. da. Jornalismo live streaming: tempo real, mobilidade e espaço urbano. In: VI ENCONTRO NACIONAL DE PESQUISADORES EM JORNALISMO DA SBPJOR. São Paulo, 2008. Artigo. Disponível em: $<$ http://sbpjor.kamotini.kinghost.net/sbpjor/admjor/arquivos/individual40fernandofirmin o.pdf>. Acesso em: ago. 2016.

SILVA, G. G. de. Breve diccionario etimológico de la lengua española. México: Elsevier, 1985.

SILVEIRA, S. C. da. Além do jornalismo móvel: o jornalismo ubíquo e o contexto de consumo de informação. Trabalho apresentado no V CONGRESSO INTERNACIONAL DE CIBERJORNALISMO. Universidade do Porto, Portugal, 2016 b.

Design de conteúdos jornalísticos pervasivos: o formato da narrativa digital móvel. Trabalho apresentado no GP Conteúdos Digitais e Convergências Tecnológicas 
do XVI ENCONTRO DOS GRUPOS DE PESQUISA EM COMUNICAÇÃO, evento componente do XXXIX CONGRESSO BRASILEIRO DE CIÊNCIAS DA COMUNICAÇÃO. Universidade de São Paulo, 2016a.

SINGER, T. Tudo conectado: conceitos e representações da internet das coisas. In: II SIMSOCIAL - II SIMPÓSIO EM TECNOLOGIAS DIGITAIS E SOCIABILIDADE. Salvador, Bahia, 2012.

SLOTERDIJK, P. Esferas III. Madrid: Siruela, 2006.

SOUZA e SILVA, A. de. From cyber to hybrid: mobile technologies as interfaces of hybrid spaces. Space and Culture, v. 9, n. 3, 2006, Sage Publications.

TASCÓN, M.; COUllaUt, A. Big data y el internet de las cosas. Madrid: Catarata, 2016.

TEIXEIRA, F. Nosso trabalho é desenhar cada vez menos interfaces. 2015. Disponível em: <https://brasil.uxdesign.cc/nosso-trabalho-\%C3\%A9-desenhar-cada-vezmenos-interfaces-acee0d004681\#.ow7tvrulu $>$ Acesso em: 9 ago 2015.

THOMAS, S. The End of Cyberspace and Other Surprises. Convergence: The International Journal of Research into New Media Technologies, Sage Publications, v. 12, n. 4, 2006.

WEISER, M. The computer for the twenty-first century. Scientific American, v. 265, n. 3, 1991 .

WESTLUND, O.; LEWIS, S. C. Agents of media innovations: actors, actants and audiences. The Journal of Media Innovations, v. 1, n. 2, p. 10-35, 2014. doi: 10.5617/jmi.v1i2.856.

WOLF, C.; SCHNAUBER, A. News Consumption in the mobile era: the role of mobile devices and traditional journalism's content within the user's information repertoire. Digital Journalism, v. 3, n. 5, 2015.

YELVINGTON, S. Ten years in new media: looking back, looking forward. 2004. Disponível em: 〈http://yelvington.com/item.php?id=404>. Acesso em: 30 abr. 2012. 